\title{
Farming systems and landscape context: effects on biodiversity and biocontrol
}

\author{
Dissertation \\ zur Erlangung des Doktorgrades \\ an der Fakultät für Agrarwissenschaften \\ der Georg-August-Universität Göttingen
}

\author{
vorgelegt von \\ Indra Roschewitz \\ geboren in Stadtoldendorf
}

Göttingen, Mai 2005 
D 7

1. Referent: Prof. Dr. Teja Tscharntke

2. Korreferent: Prof. Dr. Stefan Vidal

Tag der mündlichen Prüfung: 19.05.2005 


\section{Table of contents}

1 Farming systems and landscape context: effects on biodiversity and biocontrol. General introduction.

Introduction

Study area and organisms 9

Main questions $\quad 11$

Results and conclusions $\quad 12$

References 14

2 Are landscape complexity and farm specialisation related to land-use intensity 17 of annual crop fields?

$\begin{array}{ll}\text { Abstract } & 18\end{array}$

Introduction $\quad 19$

Material and methods $\quad 20$

Results $\quad 22$

Discussion $\quad 31$

Conclusion $\quad 33$

References $\quad 34$

3 The effects of landscape complexity on arable weed species diversity in organic 37 and conventional farming

$\begin{array}{ll}\text { Abstract } & 38\end{array}$

Introduction $\quad 39$

Material and methods $\quad 41$

Results $\quad 45$

Discussion $\quad 50$

References $\quad 53$

$\begin{array}{ll}\text { Appendix } & 57\end{array}$

4 Landscape context of organic and conventional farms: influences on carabid 61 beetle diversity

$\begin{array}{ll}\text { Abstract } & 62\end{array}$

Introduction $\quad 63$

$\begin{array}{ll}\text { Material and methods } & 64\end{array}$

$\begin{array}{ll}\text { Results } & 66\end{array}$

$\begin{array}{ll}\text { Discussion } & 68\end{array}$

$\begin{array}{ll}\text { Conclusion } & 70\end{array}$ 
References

Appendix

5 The differential effects of landscape and management on diversity and density of ground-dwelling farmland spiders

$\begin{array}{lr}\text { Abstract } & 80 \\ \text { Introduction } & 81 \\ \text { Material and methods } & 82 \\ \text { Results } & 84 \\ \text { Discussion } & 88 \\ \text { Conclusion } & 89 \\ \text { References } & 90 \\ \text { Appendix } & 94\end{array}$

6 The landscape context of cereal aphid-parasitoid interactions 97

$\begin{array}{ll}\text { Abstract } & 98\end{array}$

Introduction $\quad 99$

Material and methods $\quad 100$

$\begin{array}{ll}\text { Results } & 102\end{array}$

$\begin{array}{ll}\text { Discussion } & 105\end{array}$

$\begin{array}{ll}\text { References } & 108\end{array}$

7 The influence of landscape context and farming practices on parasitism of 113 cereal aphids

$\begin{array}{ll}\text { Abstract } & 114\end{array}$

Introduction $\quad 115$

Materials and methods $\quad 116$

$\begin{array}{ll}\text { Results } & 118\end{array}$

Discussion $\quad 123$

$\begin{array}{ll}\text { Conclusion } & 125\end{array}$

$\begin{array}{ll}\text { References } & 125\end{array}$

8 The role of arable weeds in cereal aphid-natural enemy interactions 131

$\begin{array}{ll}\text { Abstract } & 132\end{array}$

Introduction $\quad 133$

Materials and methods $\quad 134$

$\begin{array}{ll}\text { Results } & 135\end{array}$

Discussion 141

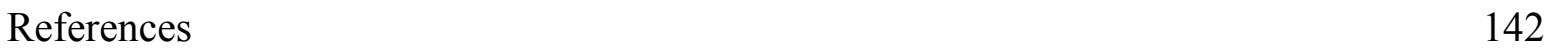


Zusammenfassung

Acknowledgements

Publications

150

Curriculum vitae 


\section{Chapter 1}

Farming systems and landscape context:

effects on biodiversity and biocontrol.

General introduction.

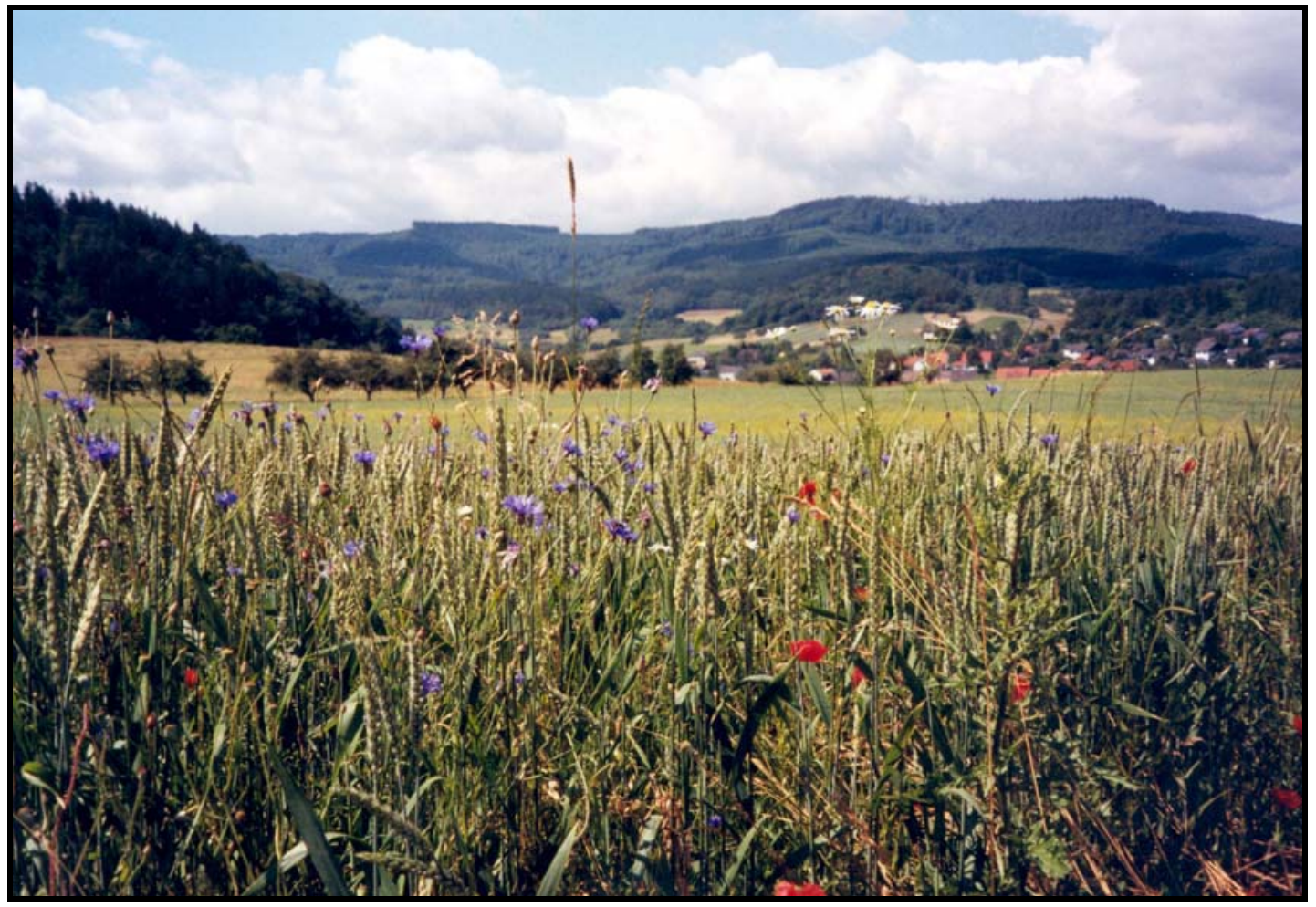




\section{Introduction}

In the last decades, increasing intensity of agricultural practices at the field scale and the spatial expansion of annual crop fields at the landscape scale, accompanied by a decrease and fragmentation of near-natural habitats, caused losses of biodiversity (Matson et al. 1997; Krebs et al. 1999; Tilman et al. 2002; Benton et al. 2003). Besides the value of biodiversity per se, biodiversity losses can also lead to losses of ecosystem functions such as biological pest control (Kruess \& Tscharntke 1994, Holt et al. 1999; Thies \& Tscharntke 1999; Gurr et al. 2003; Tscharntke et al. 2003).

Many scientific studies focused on local activities such as extensive and organic farming and their ability to support biodiversity of arthropods and plants (e.g., Dritschilo \& Erwin 1982; Kromp 1989; Paoletti 1995; Menalled et al. 2001; Hyvönen et al. 2003), but little is known about their contribution to the functioning of ecosystem services (but see Letourneau \& Goldstein 2001). However, it has been suggested that a diversification of the flora within fields can enhance natural enemies of insect pests (Root 1973; Risch et al. 1983, Russell 1989, Andow 1991; Landis et al. 2000). As arable fields are characterised by a high frequency and intensity of disturbances and many arthropods only seasonally live in fields, the complexity of the surrounding landscape may also be important for populations and the conservation of a diverse flora and fauna (e.g. Ricklefs 1987; Kareiva 1990; Jonsen \& Fahrig 1997; Menalled et al. 1999; Weibull et al. 2003; Krauss et al. 2004; Tscharntke \& Brandl 2004), by providing alternative habitats acting as refuges and sources for recolonisation of the fields. Accordingly, ecosystem functions such as parasitism of insect pests can also be influenced by the landscape context (Roland \& Taylor 1997; Thies \& Tscharntke 1999; Thies et al. 2003). However, knowledge on the relative importance of local management and regional landscape effects on biodiversity and ecosystem functioning is limited (Weibull et al. 2000; Östman et al. 2001a, b; Weibull et al. 2003). In addition, land-use intensity might be expected to change with landscape complexity and thereby affect local-regional interactions.

In this study, we first analysed the relative importance of landscape complexity and farm specialisation (different degrees of specialisation of conventional farms) on land-use intensity of annual crop fields. Then, the relative importance of farming system (organic vs. conventional) and landscape complexity on biodiversity of different groups of organisms, namely arable weeds, carabid beetles, and farmland spiders, as well as on the interactions between cereal aphids and parasitoids was investigated. Last, we experimentally analysed the role of arable weeds in cereal aphid-natural enemy interactions. 


\section{Study area and organisms}

The study was conducted in the vicinity of the city of Göttingen in southern Lower Saxony (North Germany). This area covers approx. $1350 \mathrm{~km}^{2}$ and contains slightly undulated basins with an altitude of $120-200 \mathrm{~m}$ as well as almost flat to steeply inclined mountains with an altitude of up to $480 \mathrm{~m}$. It is dominated by agricultural land use (52\%), while the remaining area is characterised by patchily distributed fragments of near-natural and semi-natural habitats such as forests (33\%), fallows, field margins, and hedgerows. The agricultural area consists of $85 \%$ arable land and $15 \%$ permanent grassland (Niedersächsisches Landesamt für Statistik 2001). $1.7 \%$ of the arable land in the study area is under organic management (Niedersächsisches Landesamt für Statistik, personal communication). The most important crops are winter cereals (71\%, mainly winter wheat Triticum aestivum), sugar beets Beta vulgaris (12\%), oilseed rape Brassica napus (8\%), and maize Zea mays (4\%). The complexity within these landscapes is not the same everywhere - there are structurally simple landscapes dominated by arable fields ( 95\%; Fig. 1A) and also very complex landscapes with less percent arable land $(\sim 30 \%)$, which is imbedded in large areas of non-crop habitats (Fig. 1B).
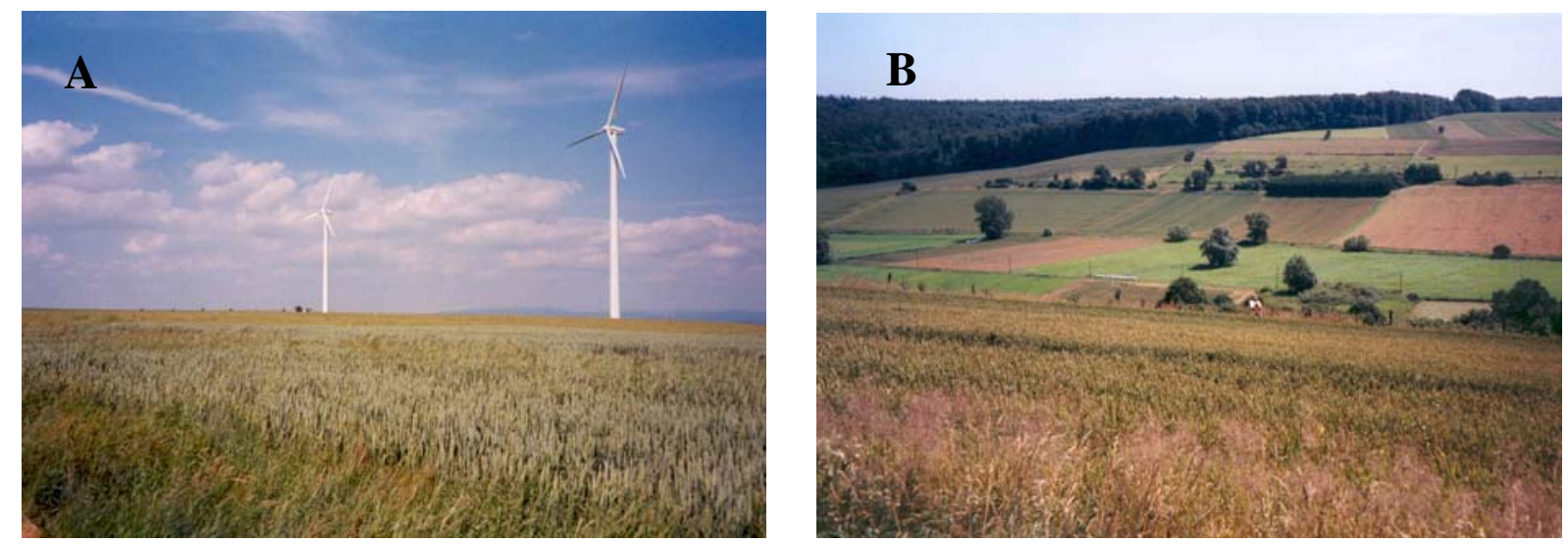

Figure 1. (A) Structurally simple landscape (near Ebergötzen) with a high percentage ( $>90 \%$ ) of arable land. (B)

Complex landscape (near Landolfshausen) with a high percentage of noncrop area $(>70 \%)$ such as fallows, field margins, forests, grasslands, and hedges.

For most parts of our study, we selected 12 landscapes along a gradient from structurally simple to complex within the study area (Fig. 2). In the centre of each of the 12 landscapes, we selected a pair of one conventionally and one organically (according to European Union Regulation 2092/91/EEC) managed winter wheat field located close to each other as study sites. 


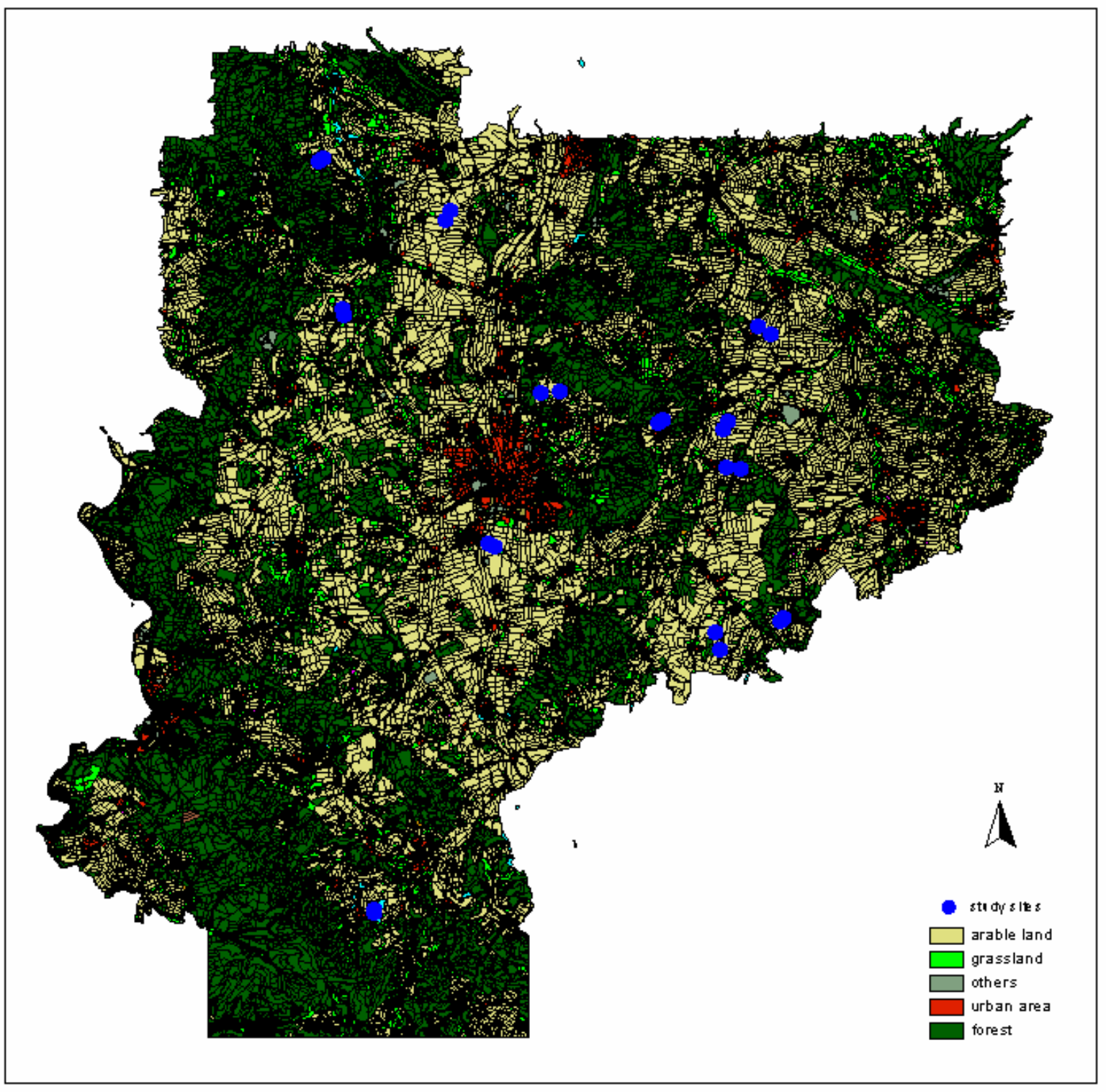

Figure 2. The study sites in the vicinity of Göttingen.

The flora of winter wheat fields is dominated by the crop plant accompanied by several species of arable weeds, which mostly are therophytes and adapted to the high frequency of disturbance (e.g., annual ploughing, cultivation). Weeds are major constraints on crop production, as they compete against the crop plant for abiotic resources such as light, water and nutrients and therefore, they are normally regulated by herbicide use in conventional farming and mechanically in organic farming. However, weeds are important contributors to biodiversity in agroecosystems, because - as primary producers - they build the basis of food chains (Marshall et al. 2003). The intensification of agriculture led to an extinction of many arable weeds, according to Korneck et al. (1996), in Germany, 32\% of the 3001 wildflower taxa are endangered or already extinct. 
The cereal aphids Sitobion avenae (Fabricius), Metopolophium dirhodum (Walker) and Rhopalosiphum padi (Linnaeus) are the most common herbivores on cereals in Germany. In years of high abundance, they can cause great economically damage (Östman et al. 2003), by phloem sucking and also acting as virus vectors. So, they are often controlled using insecticides. Several groups of natural enemies may also be able to limit aphid populations: carabid beetles (Carabidae), spiders (mainly Linyphiidae, Lycosidae, Tetragnathidae), ladybird beetles (Coccinellidae), hoverflies (Syrphidae), gall midges (Cecidomyiidae), lacewings (Chrysopidae), and parasitoid wasps (mainly Aphidiidae)(Wratten \& Powell 1991, Sigsgaard 2002, Symondson et al. 2002). All these arthropods only seasonally live in cereal fields, and therefore need perennial habitats for overwintering and/or reproduction.

\section{Main questions}

In this study, we investigated whether the land-use intensity of annual crop fields is related with landscape complexity and farm specialisation. Further, the relative importance of landscape complexity and farming system (organic vs. conventional) for biodiversity and abundance of arable weeds, carabid beetles and spiders, and for abundance and parasitism of cereal aphids was analysed. In the last chapter, the role of arable weeds in cereal aphid-natural enemy interactions was examined. Thereby, the following questions were of major importance:

Does land-use intensity decrease with increasing landscape complexity and decreasing degree of farm specialisation? In particular, does crop species diversity increase, and do field sizes, yields and the use of nitrogen fertilisers and pesticides decrease in structurally complex landscapes and in farms not specialised on annual crops? (Chapter 2)

Is the alpha, beta, and gamma diversity of arable fields higher in organic than in conventional fields and in complex than in simple landscapes? Can landscape complexity compensate for the reduced diversity in conventional fields? Do several rare weed species especially profit from organic farming and/or landscape complexity? (Chapter 3)

What are the relative effects of farming system and landscape complexity on species richness and activity density of carabid beetles? Does the impact of landscape and management factors differ between carabids with different life cycles? (Chapter 4)

What is the relative importance of farming system and landscape complexity for species richness and activity density of ground-living spiders? Are landscape effects on spiders more important in conventional than in organic fields? (Chapter 5) 
Is aphid mortality due to parasitism increased and aphid density decreased in structurally complex landscapes? Is aphid parasitism higher and aphid abundance lower in organic than in conventional fields? Do aphids and their parasitoids respond to landscape structure at different spatial scales? (Chapter 6 and 7)

Does a high cover of arable weeds decrease aphid colonisation of wheat due to a less easily finding of host plants? Does a high cover of arable weeds decrease overall aphid abundance due to an increase in the abundance of natural enemies? (Chapter 8)

\section{Results and conclusions}

Landscape complexity and farm specialisation were related to many, but not all indicators of land-use intensity. Farms specialised on annual crops had reduced crop-species diversity, larger fields, higher crop yields and more pathogen species. Landscapes with high percent annual crops were related to larger fields, more nitrogen input and higher crop yields. So, landscape complexity and farm specialisation revealed to be indicators for several parameters of land-use intensity, but, in contrast to expectations, not of pesticide use, which was exceptionally high. Results show that generalisations such as "farms specialised on annual crops and structurally simple landscapes show increased land-use intensity" may be misleading. As this study was regionally restricted, further studies on the relation of land-use intensity to landscape and farm characteristics are needed. (Chapter 2)

Overall weed diversity was greatly determined by the high heterogeneity between and within the fields (beta diversity). Local weed species diversity in the vegetation, the seed rain and the seedbank was higher in organic than in conventional fields. Increasing landscape complexity enhanced species diversity in the vegetation of conventional, but little of organic fields, resulting in nearly similar diversity in both farming systems when the landscape was complex. Species diversity of the seedbank was increased by landscape complexity irrespective of farming system. Higher weed species diversity in complex landscapes and/or organic farming could only in very few cases be related to particular species depending on such landscapes or farming system. In conclusion, organic fields were per se highly diverse, while biodiversity in conventional fields profited from landscape complexity. Consequently, agri-environment schemes to preserve and enhance biodiversity should not only consider the management of single fields, but also of the surrounding landscape. (Chapter 3)

Carabid beetle species richness and activity density did not differ between organic and conventional fields. Seven species were more abundant under organic management, and eight species were more abundant under conventional management. The effect of landscape 
complexity was independent of management system. Species richness increased with percent grassland in the surrounding landscape, and activity density followed the same trend. Hence, surrounding grassland appeared to act as a major source of diversity for farmland carabids. In particular, the activity density of spring breeders on organic fields benefited from the increased availability of overwintering habitats in their close surrounding. In conclusion, landscape features were much more important than organic farming for enhancement of local carabid diversity and should thus be considered in agri-environment schemes. (Chapter 4)

High percentages of non-crop habitats in the landscape increased local species richness of spiders, irrespective of local management. This indicates that larger species pools are sustained in complex landscapes with a higher availability of refuge and overwintering habitats. Organic agriculture did not increase the number of spider species, but enhanced spider density by $62 \%$. Additionally, spider density was positively related to the percentage of non-crop habitats in the surrounding landscape, but only in conventional fields. Thus, landscape complexity can promote and conserve biodiversity of ground-dwelling spiders, while organic farming can enhance spider densities. Therefore, complex landscapes should be preserved or restored and organic farming should be applied to higher proportions of the landscape than it is currently the case. (Chapter 5)

Population density and parasitism of aphids in conventional wheat fields varied greatly between years and were associated with the landscape context at different spatial scales. Complex landscapes were associated with increased aphid mortality resulting from parasitism, but also with higher aphid colonisation, thereby counterbalancing possible biological control by parasitoids and lastly resulting in similar aphid densities across landscapes. Thus, undisturbed perennial habitats appeared to enhance both pests and natural enemies. Analyses at multiple spatial scales (landscape sectors of $0.5-6 \mathrm{~km}$ diameter) showed that correlations between parasitism and percent arable land were significant at scales of $0.5-$ $2 \mathrm{~km}$, whereas aphid densities responded to percent arable land at scales of 1-6km diameter. Hence, the higher trophic level populations appeared to be determined by smaller landscape sectors owing to dispersal limitation, showing the 'functional spatial scale' for speciesspecific landscape management. (Chapter 6)

The analyses of population density and parasitism of aphids in organic and conventional fields revealed resembling results as in Chapter 6. Aphid population densities varied considerably between years and landscapes. Organic farming was related to lower abundance of cereal aphids at the time of wheat flowering, but not to higher parasitism. At wheat ripening, complex landscapes were related to higher parasitism than simple landscapes, presumably due to more overwintering sites, alternative hosts and nectar sources for parasitoids. However, aphid population densities were also higher in complex landscapes, 
presumably due to the high availability of winter hosts for these host-alternating species. Analyses at 5 spatial scales (1-3 km radius around the study sites) showed that parasitoids responded to landscape complexity at spatial scales of 1 to $2 \mathrm{~km}$, whereas aphid densities responded to landscape complexity at all spatial scales, indicating a trophic level-specific perception of the surrounding landscape. We conclude that organic farming did not contribute to biocontrol of cereal aphids, and that complex landscapes with low percentage of arable land appeared to enhance parasitism, but also the host-alternating aphids, so overall effects of landscape complexity on cereal aphid control appear to be ambivalent. (Chapter 7)

Within a field experiment using weed treatments with six herbaceous, six grass, and six herbaceous plus six grass species, respectively, with either 5 or $20 \%$ vegetation cover, the naturally occurring aphid Metopolophium dirhodum colonised the weedless control in 400\% higher densities than the herb and grass treatment with $20 \%$ cover. Flying predator densities were enhanced by weeds, especially when herbs and grasses covered 20\%. Accordingly, released populations of Sitobion avenae and also of natural occurring aphids were lowest in this treatment (500\% lower than in the control), thereby falling below the threshold level of economic damage. Parasitoid densities were low and not influenced by weeds. Wheat biomass did not differ between the treatments, suggesting that potential losses in biomass resulting from resource competition between wheat and weeds were compensated by the lower aphid densities in the weedy treatments. This suggests that a reduction in spraying intensity of herbicides could also lead to a reduction of insecticide use, which can be utilised to convert intensive farming to environmentally more sound farming practices. Thereby, plant biodiversity could be supported and ecosystem services could be utilised for sustainable food production. (Chapter 8)

\section{References}

Andow, D.A. (1991) Vegetational diversity and arthropod population response. Annu. Rev. Entomol. 36, 561-586.

Benton, T.G., Vickery, J.A., Wilson, J.D. (2003) Farmland biodiversity: is habitat heterogeneity the key? Trends Ecol. Evol. 18, 182-188.

Dritschilo, W., Erwin, T.L. (1982) Responses in abundance and diversity of cornfield carabid communities to differences in farm practices. Ecology 63, 900-904.

Gurr, G.M., Wratten, S.D., Luna, J.M. (2003) Multi-function agricultural biodiversity: pest management and other benefits. Basic Appl. Ecol. 4, 107-116.

Holt, R.D., Lawton, J.H., Polis, G.A., Martinez, N.D. (1999) Trophic rank and the species area relationship. Ecology 80, 1495-1504. 
Hyvönen, T., Ketoja, E., Salonen, J., Jalli, H., Tiainen, J. (2003) Weed species diversity and community composition in organic and conventional cropping of spring cereals. Agric. Ecosyst. Environ. 97, 131-149.

Jonsen, I.D., Fahrig, L. (1997) Response of generalist and specialist insect herbivores to landscape spatial structure. Landscape Ecol. 12, 185-197.

Kareiva, P. (1990) Population dynamics in spatially complex environments: theory and data. Phil. Trans. R. Soc. Lond. B 330, 175-190.

Korneck, D., Schnittler, M., Vollmer, I. (1996) Rote Liste der Farn- und Blütenpflanzen (Pteridophyta et Spermatophyta) Deutschlands. Schriftenreihe für Vegetationskunde, 28, 21-187.

Krauss, J., Klein, A.M., Steffan-Dewenter, I., Tscharntke, T. (2004) Effects of habitat area, isolation, and landscape diversity on plant species richness of calcareous grasslands. Biodivers. Conserv. 13, 1427-1439.

Krebs, J.R., Wilson, J.D., Bradbury, R.B., Siriwardena, G.M. (1999) The second silent spring? Nature, 400, 611-612.

Kromp, B. (1989) Carabid beetle communities (Carabidae, Coleoptera) in biologically and conventionally farmed ecosystems. Agric. Ecosyst. Environ. 27, 241-251.

Kruess, A., Tscharntke, T. (1994) Habitat fragmentation, species loss, and biological control. Science 264, 1581-1584.

Landis, D.A., Wratten, S.D., Gurr, G.M. (2000) Habitat management to conserve natural enemies of arthropod pests in agriculture. Annu. Rev. Entomol. 45, 175-201.

Letourneau, D.K., Goldstein, B. (2001) Pest damage and arthropod community structure in organic vs. conventional tomato production in California. J. Appl. Ecol. 38, 557-570.

Marshall, E.J.P., Brown, V.K., Boatman, N.D., Lutman, P.J.W., Squire, G.R., Ward, L.K. (2003) The role of weeds in supporting biological diversity within crop fields. Weed Res. 43, 77-89.

Matson, P.A., Parton, W.J., Power, A.G., Swift, M.J. (1997) Agricultural intensification and ecosystem properties. Science 277, 504-509.

Menalled, F.D., Gross, K.L., Hammond, M. (2001) Weed aboveground and seedbank community responses to agricultural management systems. Ecol. Appl. 11, 1586-1601.

Menalled, F. D., Marino, P. C., Gage, S. H., Landis, D. A. (1999) Does agricultural landscape structure affect parasitism and parasitoid diversity? Ecol. Appl. 9, 634-641.

Niedersächsisches Landesamt für Statistik (2001) Agrarstrukturerhebung 2001.

Östman, Ö., Ekbom, B., Bengtsson, J. (2003) Yield increase attributable to aphid predation by ground-living polyphagous natural enemies in spring barley in Sweden. Ecol. Econom. $45,149-158$.

Östman, Ö., Ekbom, B., Bengtsson, J., Weibull, A.C. (2001a) Landscape complexity and farming practice influence the condition of polyphagous carabid beetles. Ecol. Appl. 11, 480-488. 
Östman, Ö., Ekbom, B., Bengtsson, J. (2001b) Landscape heterogeneity and farming practice influence biological control. Basic Appl. Ecol. 2, 365-371.

Paoletti, M.G. (1995) Biodiversity, traditional landscapes and agroecosystem management. Landscape Urban Plann. 31, 117-128.

Ricklefs, R.E. (1987) Community diversity: relative roles of local and regional processes. Science, 235, 167-171.

Risch, S. J., Andow, D., Altieri, M. A. (1983) Agroecosystem diversity and pest control: data, tentative conclusions, and new research directions. Environ. Entomol. 12, 625-629.

Roland, J., Taylor, P. D. (1997) Insect parasitoid species respond to forest structure at different spatial scales. Nature 386, 710-713.

Root, R.B. (1973) Organization of a plant-arthropod association in simple and diverse habitats: The fauna of collards (Brassica oleraceae). Ecol. Monogr. 43, 95-124.

Russell, E.P. (1989) Enemies Hypothesis: A review of the effect of vegetational diversity on predatory insects and parasitoids. Environ. Entomol. 18, 590-599.

Sigsgaard, L. (2002) A survey of aphids and aphid parasitoids in cereal fields in Denmark, and the parasitoids' role in biological control. J. Appl. Entomol. 126, 101-107.

Symondson, W.O.C., Sunderland, K.D., Greenstone, H.M. (2002) Can generalist predators be effective biocontrol agents? Annu. Rev. Entomol. 47, 561-594.

Thies, C., Tscharntke, T. (1999) Landscape structure and biological control in agroecosystems. Science 285, 893-895.

Thies, C., Steffan-Dewenter, I., Tscharntke, T. (2003) Effects of landscape context on herbivory and parasitism at different spatial scales. Oikos 101, 18-25.

Tilman, D., Cassman, K. G., Matson, P. A., Naylor, R., Polaski, S. (2002) Agricultural sustainability and intensive production practices. Nature 418, 671-677.

Tscharntke, T., Brandl, R. (2004) Plant-insect interactions in fragmented landscapes. Аnnu. Rev. Entomol. 49, 405-430.

Tscharntke T., Klein A.-M., Kruess A., Steffan-Dewenter I., Thies C. (2003) Biodiversität und Pflanze-Insekt-Interaktionen in Kulturlanschaften. In: Biodiversitätsforschung. Die Entschlüsselung von Artenvielfalt in Raum und Zeit (eds Grandstein, S.R., Willmann, R., Zizka, G.), pp. 171-183. E. Schweizbart'sche Verlagsbuchhandlung, Stuttgart.

Weibull, A.C., Bengtsson, J., Nohlgren, E. (2000) Diversity of butterflies in the agricultural landscape: the role of farming system and landscape heterogeneity. Ecography 23, 743750 .

Weibull, A.C., Östman, Ö., Granqvist, A. (2003) Species richness in agroecosystems: The effect of landscape, habitat and farm management. Biodiv. Conserv. 12, 1335-1355.

Wratten, S.D., Powell, W. (1991) Cereal aphids and their natural enemies. In: The ecology of temperate cereal fields. 32nd Symp. Br. Ecol. Soc. (eds Firbank, I.G., Carter, N., Darbyshire, J.F., Potts, G.R.), pp. 233-257.Oxford: Blackwell Scientific. 


\title{
Chapter 2
}

\section{Are landscape complexity and farm specialisation related to land- use intensity of annual crop fields?}

\author{
Indra Roschewitz, Carsten Thies \& Teja Tscharntke
}

Agriculture, Ecosystems and Environment 105 (2005) 87-99

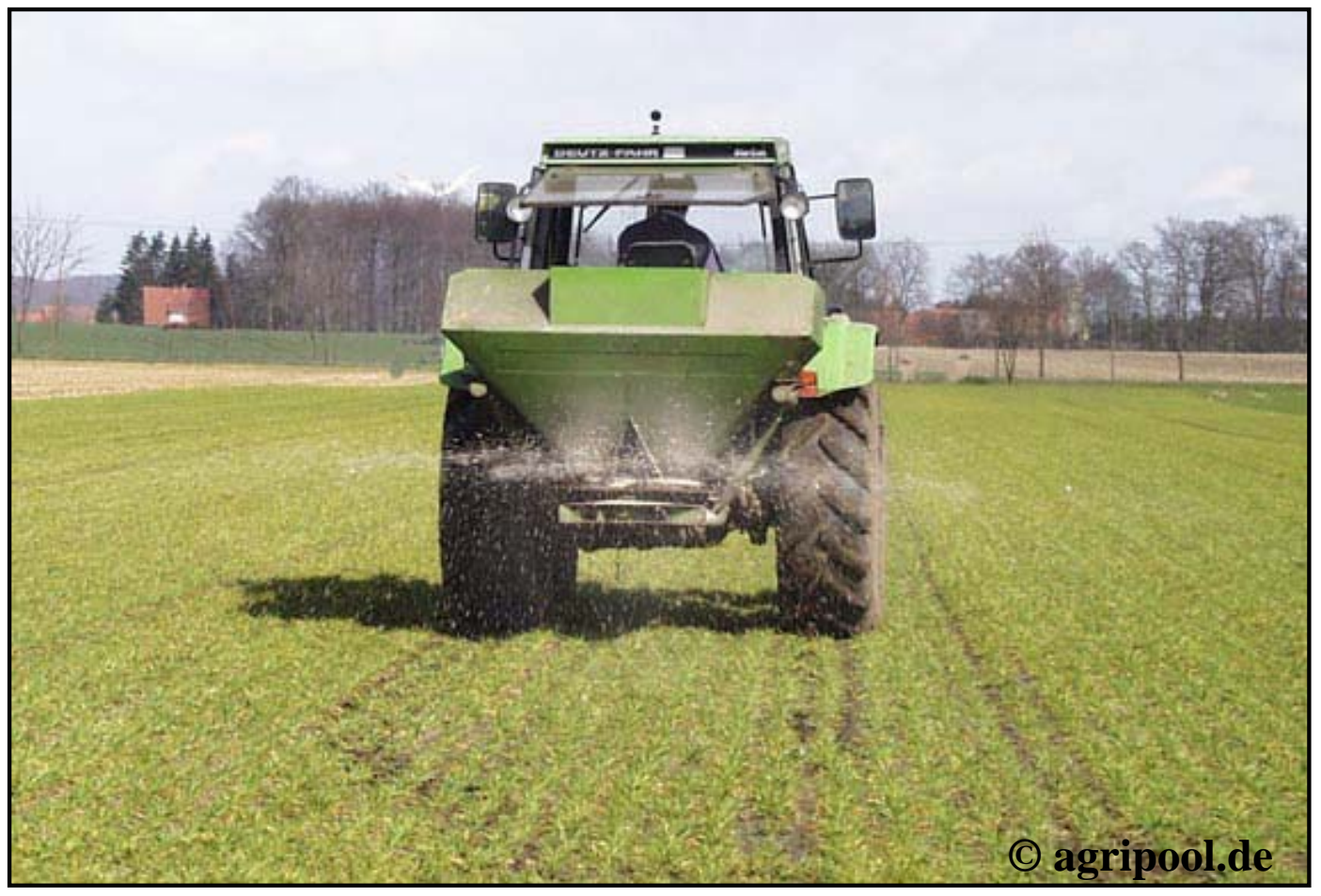




\begin{abstract}
Little is known about the predictive value of landscape complexity and farm specialisation for land-use intensity, although this is critical for regional agri-environmental schemes and conservation of biodiversity. Here, we analysed land-use intensity of annual crop fields of 30 farms in northern Germany that were located in 15 landscapes differing in structural complexity ranging from $<15 \%$ to $>65 \%$ noncrop habitats. The proportion of arable land per landscape was used as simple predictor of landscape complexity due to its close correlation with habitat-type diversity, and the proportion of arable land per farm acted as an indicator for farm specialisation due to its negative correlation with stock farming. Land-use intensity was quantified using questionnaires. Landscape complexity and farm specialisation were related to several but not all indicators of land-use intensity. Structurally simple landscapes were related to more nitrogen input and higher crop yields, and farms specialised on annual crops had reduced crop-species diversity, larger fields, higher crop yields and more pathogen species. In contrast to general expectations, pesticide use in annual crop fields was exceptionally high and not a function of landscape complexity or farm specialisation. Our results show that generalisations such as "farms specialised on annual crops and structurally simple landscapes show increased land-use intensity" may be misleading.
\end{abstract}

\title{
Key words
}

Conservation, cereal fields, pesticide use, grassland, biodiversity, Lower Saxony (Germany). 


\section{Introduction}

Since the beginnings of agriculture, land-use practices were steadily improved resulting in a food supply that (theoretically) has been able to feed the increasing world population. For example, in the last 40 years the global cereal production has doubled (FAO, 2001), which can mainly be ascribed to increasing yields resulting from new technologies of the "Green Revolution" such as greater inputs of fertilisers and pesticides. However, modern agriculture as well as agricultural landscapes are multifunctional, as they do not only provide food, water and other marketable goods, but also environmental goods (Marggraf and Streb, 1997). Intensification of agricultural practices caused ecological problems such as environmental pollution and biodiversity losses (Matson et al., 1997; Krebs et al., 1999; Tilman et al., 2001, 2002). Land consolidation caused a change from formerly complex landscapes with wellbalanced proportions of arable land, grassland, forests, fallows, hedgerows and other natural and semi-natural habitats to simple landscapes with high proportions of arable land.

The trade-off among ecological and economical goods is one of the greatest scientific challenges facing humankind (Tilman et al., 2002). Agri-environmental schemes in the form of management agreements on fields do not necessarily protect species richness of several groups (plants, birds) effectively (Kleijn et al., 2001). On the one hand, such analyses of effectiveness of these schemes at the "field scale" may be a prerequisite to improve current schemes. On the other hand, effects of land-use intensity on local biodiversity and ecological functioning depend on spatial scales much larger than a single field. This demands the use of a landscape perspective, i.e. the "landscape scale", considering area and spatial arrangement of the surrounding land-use types (Kareiva, 1990; Turner and Gardner, 1991; Kareiva and Wennergren, 1995; Pickett and Cadenasso, 1995; Polis et al., 1997; Roland and Taylor, 1997; Gonzalez et al., 1998; Menalled et al., 1999; Thies and Tscharntke, 1999; Wiegand et al., 1999; Cadenasso and Pickett, 2000; Tischendorf and Fahrig, 2000; Ricketts, 2001; Thies et al., 2003). Only few studies investigated the relationship between farm characteristics and landscape structure. Thenail (2002) showed that production, economic levels, productivity and technical means of dairy farms increased as hedgerow density in a "bocage" landscape decreased. Thenail and Baudry (2004) analysed the relationship between farm spatial land-use pattern and hedgerow structure in the same region. They found different degrees of land-use allocation in farms depending on the hedgerow density, which in turn influenced the landscape structure. Whether land-use intensity of annual fields also changes with changing landscape context is not well known yet; intensity may also be related to farm specialisation on annual cropping.

In this paper, we analysed the relative impact of landscape complexity and farm specialisation on local land-use intensity of annual crop fields in southern Lower Saxony (northern Germany). Farm sizes, proportions of different land-use types, and livestock of 30 farms were analysed to quantify and characterise their degree of specialisation towards annual cropping. 
Data on crop species, yields, the use of nitrogen fertilisers and pesticides, and field sizes of a set of fields cultivated by these farms were collected to quantify land-use intensity. The analysed sets of fields were located in 15 landscapes (i.e. fields of two farmers per landscape) differing in structural complexity ranging from structurally simple landscapes with a high proportion of annual crop fields to structurally complex landscapes with large areas of noncrop habitats such as fallows, field margins, hedges, grasslands, and forests. We expected (1) that crop species diversity increases, and the field sizes, yields as well as the use of nitrogen fertilisers and pesticides decrease in structurally complex landscapes, and (2) that crop species diversity decreases, and the field sizes, yields as well as the use of nitrogen fertilisers and pesticides increase in farms specialised on annual crops (Haber and Salzwedel, 1992; Mander et al., 1999).

\section{Material and methods}

\section{Study area}

The study was conducted in agricultural landscapes of Southern Lower Saxony (North Germany). This area is characterised by cropland-grassland mosaics, which are dominated by agricultural land use covering on average about $75 \%$ of the region, and patchily distributed fragments of semi-natural habitats such as grasslands, fallows, hedges, and forests. We selected 15 non-overlapping circular landscape sectors with a diameter of 5000m. These landscape sectors represent a gradient in landscape complexity ranging from extremely simple and structurally poor landscapes with a high proportion of annual crop fields $(>85 \%)$ to structurally complex landscapes with large areas of noncrop habitats such as fallows, field margins, grasslands, hedges, and forests ( $>65 \%$ noncrop area). The distribution of landscape complexity did not show any north-south or east-west gradient to prevent potential problems such as correlations between landscape complexity and abiotic factors (e.g. soil fertility; see Steffan-Dewenter et al., 2002). In general, the soil in the 15 landscapes was dominated by leptosols (35.7\%), followed by luvisols (27.7\%), cambisols (23.7\%), fluvisols $(5.9 \%)$, anthrosols (3.9\%), and chernozems (3.1\%) (according to official data of the Niedersächsisches Landesamt für Bodenforschung, 1997; for classification, see FAOUNESCO, 1990).

\section{Analysis of landscape structure, farm specialisation, and land-use intensity}

Landscape structure was estimated in 15 circular landscape sectors of 5000m diameter. We used official digital thematic maps (ATKIS - Digitales Landschaftsmodell 25/1; Landesvermessung und Geobasisinformation, Hannover, Germany, 1991-1996) and the Geographical Information System ArcView 3.1 (ESRI Geoinformatik GmbH, Hannover, Germany) to measure the area of arable land, perennial grassland, forests, hedgerows, garden land, and settlement in each of the 15 landscape sectors. Farm specialisation and land-use 
intensity were recorded using questionnaires of two randomly selected "full-time" farmers per landscape. Thereby it was possible to analyse a total of 166 crop fields ( $11 \pm 6$ fields per landscape sector) covering $838 \mathrm{ha}(56 \pm 28 \mathrm{ha}$ per landscape sector). The analysed farms were representative for the study region with regard to their proportions of land-use types and their levels of specialisation (see Geries Ingenieure, 2002). To analyse farm specialisation, we asked the farmers for farm size, and the proportions of arable land, grassland, and forests per farm as well as for their numbers of livestock. The fields came partly from outside the landscape sectors, but as the farmers tend to manage all their fields in a similar way, this did not appear to affect our results. Land-use intensity was quantified for all arable fields cultivated by the two farmers and situated in the landscape sectors via the use of nitrogen fertiliser ( $\mathrm{kg} / \mathrm{ha}$ ) and crop yields ( $\mathrm{t} / \mathrm{ha}$ ) as well as the use of pesticides (number of applications per year of herbicides, fungicides, insecticides, respectively) in each of the cultivated annual crops. We did not quantify the use of specific substances of pesticides, because their relative ecotoxicity is not known well, and thus, not comparable. We also asked the farmers for the number of problematic species (i.e., weeds, pathogens, and pest insects which farmers fight with pesticides) to examine the reasons of chemical plant protection in annual crops. Additionally, field sizes and crop species diversity were measured. Small fields provide a higher percentage of ecologically useful field margins (e.g. Hunter, 2002). A higher diversity of crop species is associated with a higher floristic and faunistic diversity and a reduced probability of pest outbreaks and pesticide use (McLaughlin and Mineau, 1995; Ellenberg, 1996; Hofmeister and Garve, 1998). Field margin management was not analysed as the margins in the study region are all perennial, regularly mowed once a year, and therefore quite homogeneous and dominated by grasses.

\section{Statistical analysis}

Logarithmic transformation of the variables was used to achieve normality of the residuals from the statistic models and arcsine-square-root transformation of $\mathrm{p}$ for the proportions (Sokal and Rohlf, 1995). We used multiple regression analyses with backward selection to examine the impact of landscape complexity and farm specialisation on land-use intensity. The proportion of arable land per farm, i.e. the mean area of two farms per landscape ploughed annually for the cultivation of annual crops, was considered as a simple parameter for farm specialisation, because of its correlation with farm size and other structural parameters (see results). The proportion of arable land per landscape was considered as a simple parameter for the quantification of landscape complexity, because of its close correlation with other landscape metrics such as land-use type diversity, habitat isolation and perimeter-to-area ratio, and because arable land is the largest land-use type in our region (see results; Steffan-Dewenter et al., 2002; Thies et al., 2003). We examined the relationship between the predictor variables "arable land (\%) per farm" and "arable land (\%) per landscape" on mean field size (ha), crop species diversity, crop yields (t/ha), and the use of 
nitrogen fertilisers (kg N/ha) and herbicides, fungicides, and insecticides (applications/year). As not all crop species were present in each of the 15 landscapes, we pooled the use of nitrogen fertilisers ( $\mathrm{kg} \mathrm{N} / \mathrm{ha}$ ) and pesticides (applications/year) for all monocotyledonous crop species, which were cereals including maize (wheat (Triticum aestivum), winter barley (Hordeum vulgare), winter rye (Secale cereale), Triticale (Triticum secale), summer oats (Avena sativa), and silage maize (Zea mays)), and for dicotyledonous crop species, namely sugar beets (Beta vulgaris) and oilseed rapecrop (Brassica napus). Maize was excluded from the monocot group in the case of nitrogen fertilisation, because it also received manure, and the farmers were not able to quantify the respective $\mathrm{N}$-input by manure.

Data on land-use intensity in the landscapes were first of all averaged per farm and thereafter per landscape to prevent possible confounding effects of larger farms taking up larger areas of the landscape and thereby biasing correlations between farm and landscape scales. In the text and in the tables, arithmetic means \pm standard deviations (SD) are given.

\section{Results}

\section{Characteristics of landscape complexity and farm specialisation}

Landscape complexity was characterised by the proportion of each land-use type in a landscape sector of 5000m diameter. Digital thematic maps allowed us to distinguish six landuse types. Dominant land-use types were arable land, grassland, and forests. For example, the mean percentage of arable land (the quantitatively most important land-use type) was 55.2 $\pm 19.8 \%$ (min: 26.2\%; max.: 86.9\%) per landscape. Farms were characterised by farm size, the proportions of arable land, grassland, and forests, and stock farming, i.e. the number of animals per farm. The mean farm size was 181.1 \pm 135.5 ha (min.: 21ha; max.: 658ha). Dominant land-use types were arable land and grassland. For example, the mean proportion of arable land per farm was $82.5 \pm 16.4 \%$ (min.: 54.6\%; max.: 100\%). Stock farming was dominated by cattle and fattened pigs, whereas only few farmers owned horses, sheep, sows, and hens (Table 1). Nine of the 30 farms in seven of the 15 landscape sectors hold cattle, while 13 farms in eight landscape sectors hold pigs. The maximum herd size of cattle was 320 , which was not typical for the study region. The mean herd size of cattle farmers except this one "outlier" was 65. 
Table 1. Characteristics of landscape structure of 15 landscape sectors and farm specialisation of 30 farms within these 15 landscapes.

\begin{tabular}{lccc}
\hline & Mean \pm SD & Minimum & Maximum \\
\hline Landscape structure characteristics: & & & \\
& & & \\
Habitat type (\%) & & & \\
Arable land & $55.2 \pm 19.8$ & 26.2 & 86.9 \\
Grasslands & $11.6 \pm 4.7$ & 4.5 & 19.2 \\
Forests & $25.0 \pm 18.0$ & 0.3 & 54.0 \\
Hedgerows & $0.2 \pm 0.2$ & 0.0 & 0.5 \\
Garden land & $0.3 \pm 0.2$ & 0.0 & 0.8 \\
Settlement & $6.7 \pm 3.9$ & 3.1 & 19.1
\end{tabular}

Farm specialisation characteristics:

Land-use (ha per farm)

$\begin{array}{lccc}\text { Arable land } & 167.8 \pm 136.0 & 12.0 & 658.0 \\ \text { Grassland } & 12.9 \pm 20.8 & 0.0 & 87.0 \\ \text { Forests } & 0.5 \pm 1.9 & 0.0 & 10.0\end{array}$

Stock farming (individuals per farm)

$\begin{array}{lccc}\text { Cattle } & 31.0 \pm 67.0 & 0.0 & 320.0 \\ \text { Fattened pigs } & 176.0 \pm 478.0 & 0.0 & 2300.0 \\ \text { Sows } & 16.0 \pm 82.0 & 0.0 & 450.0 \\ \text { Horses } & 1.0 \pm 4.0 & 0.0 & 23.0 \\ \text { Sheep } & 0.1 \pm 0.6 & 0.0 & 3.0 \\ \text { Hens } & 18.0 \pm 91.0 & 0.0 & 500.0\end{array}$

The Shannon diversity of all land-use types and the proportion of arable land per landscape were negatively correlated (Fig. 1), indicating arable land as a simple predictor of landscape complexity. The proportion of arable land per landscape and farm sizes were not correlated $(R=0.055, P=0.780)$, i.e., large farms were not necessarily located in landscapes of low complexity. However, farm size was positively correlated with the proportion of arable land per farm $(R=0.612, P=0.015)$, and negatively correlated with the proportion of grassland per farm $(R=-0.624, P=0.013)$. The number of cattle per farm decreased as the percentage of arable land per farm increased $(R=-0.916, P<0.001)$ and increased as the percentage of grassland per farm increased $(R=0.910, P<0.001)$, suggesting a specialisation of bigger farms towards annual crops and a specialisation of smaller farms towards livestock of cattle. In contrast, the number of fattened pigs did neither correlate with the proportion of arable land 
$(R=0.192, P=0.493)$ nor with the proportion of grassland per farm $(R=-0.162, P=0.565)$. The number of cattle per ha farmland $(0.88 \pm 0.53$; min.: 0.03 ; max.: $1.86 ; \mathrm{n}=9$ cattle owners) as well as the number of fattened pigs per ha farmland $(2.83 \pm 4.44$; min.: 0.02 ; max.: 12.78; $\mathrm{n}=13$ pig owners) were not correlated with farm size (cattle per ha: $R=-0.389, P=0.300$; fattened pigs per ha: $R=0.237, P=0.436$ ).

The proportion of arable land per landscape and the proportion of arable land per farm were not correlated $(R=0.269, P=0.333)$. So, in our landscapes, the proportion of arable land per farm could be used as a simple predictor of farm specialisation towards the production of annual crops.

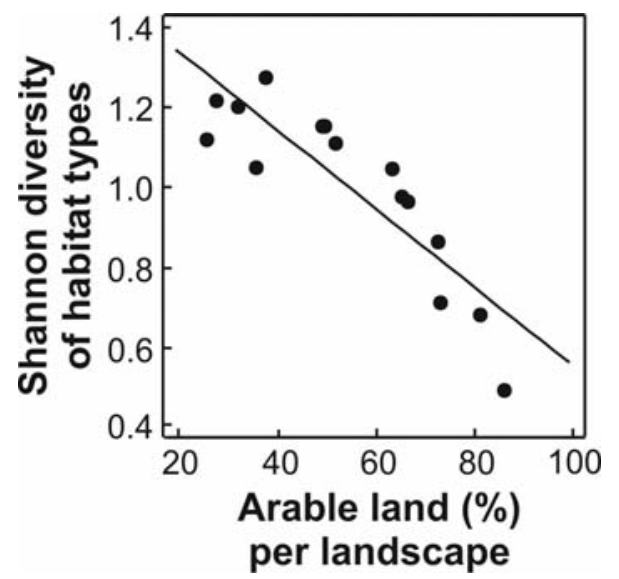

Figure 1. The habitat-type diversity after Shannon-Wiener in relation to the percentage of arable land on a landscape scale $\left(F=39.00 ; P<0.001 ; R^{2}=75.000 \% ; \mathrm{n}=15 ; Y=1.562-0.010 X\right)$.

\section{Effects of landscape complexity and farm specialisation on land-use intensity}

In multiple regression analyses, field sizes, crop species diversity, nitrogen fertilisation, and pesticide application were related to farm specialisation and landscape context, i.e. the proportion of arable land per farm and the proportion of arable land per landscape, respectively.

Mean field size of annual crop fields was 5.3 \pm 2 .6ha and varied between 1.3 ha and 10.1ha. The mean size of annual crop fields was positively correlated with the proportion of arable land per farm, indicating that such specialised farms till on larger fields (Fig. 2a and b). A total of eight crop species was cultivated on annual fields. Dominant crop species were winter wheat, winter barley, sugar beets, and oilseed rape (Table 2). The mean number of cultivated crop species was 3.6 \pm 1.3 per farm (min.: 2; max.: 6). Farmers cultivated $2.4 \pm 1.2$ species of cereal crops (min.: 1; max.: 5), and $1.2 \pm 0.7$ species of dicotyledonous crops (min.: 0 ; max.: 2). The mean crop species diversity (after Shannon-Wiener) per farm was $1.0 \pm 0.4$ (min.: 0.4; max.: 1.7). For cereals, it was $0.6 \pm 0.3$ and varied between 0.2 and 1.1 , whereas it was $0.3 \pm 0.2$ for dicots (min.: 0; max.: 0.7). The diversity of crop species was negatively correlated with the proportion of arable land per farm $(R=-0.527, P=0.043)$, indicating annual-crop 
specialised farms to cultivate less diversity of crop species. In particular, diversity of cereal crop species was negatively correlated with the proportion of arable land per farm, whereas diversity of dicot species did not correlate with the proportion of arable land per farm (Fig. $2 \mathrm{c})$. Crop species diversity was not correlated with the proportion of arable land per landscape (Fig. 2d).

Table 2. Proportion of annual crop species (\%) and the height of crop yields (t/ha) in 15 landscape sectors.

\begin{tabular}{|c|c|c|c|c|c|c|}
\hline \multirow[t]{2}{*}{ Crop species } & \multicolumn{3}{|c|}{ Proportion (\%) } & \multicolumn{3}{|l|}{ Yields (t/ha) } \\
\hline & Mean \pm SD & Minimum & Maximum & Mean \pm SD & Minimum & Maximum \\
\hline Wheat $(T \text {. aestivum })^{1)}$ & $53.3 \pm 18.6$ & 22.0 & 80.0 & $8.3 \pm 0.7$ & 7.3 & 10.0 \\
\hline Winter barley $(H$. vulgare) & $12.0 \pm 12.1$ & 0.0 & 42.1 & $7.4 \pm 1.0$ & 5.0 & 8.6 \\
\hline Winter rye (S. cereale) & $4.4 \pm 14.3$ & 0.0 & 55.0 & $8.2 \pm 0.8$ & 7.5 & 9.0 \\
\hline Triticale ( $T$. secale) & $1.1 \pm 2.6$ & 0.0 & 8.8 & $7.4 \pm 0.8$ & 6.5 & 8.0 \\
\hline Summer oats $(A . \text { sativa })^{2)}$ & $0.2 \pm 0.7$ & 0.0 & 2.8 & 5.0 & - & - \\
\hline Maize $(Z \text {. mays })^{2)}$ & $4.4 \pm 7.5$ & 0.0 & 19.5 & 40.0 & - & - \\
\hline Oilseed rape (B. napus) & $8.3 \pm 12.9$ & 0.0 & 48.6 & $3.6 \pm 0.5$ & 2.5 & 4.0 \\
\hline Beets (B. vulgaris) $)^{3)}$ & $12.2 \pm 13.7$ & 0.0 & 42.9 & $53.9 \pm 4.1$ & 45.0 & 57.5 \\
\hline
\end{tabular}

1) $52.9 \pm 19.3 \%$ winter wheat, $0.4 \pm 1.4 \%$ summer wheat.

2) Only one farmer could specify the height of the yields.

3) $11.6 \pm 14.0 \%$ sugar beets, $0.5 \pm 2.1 \%$ feed beets. 

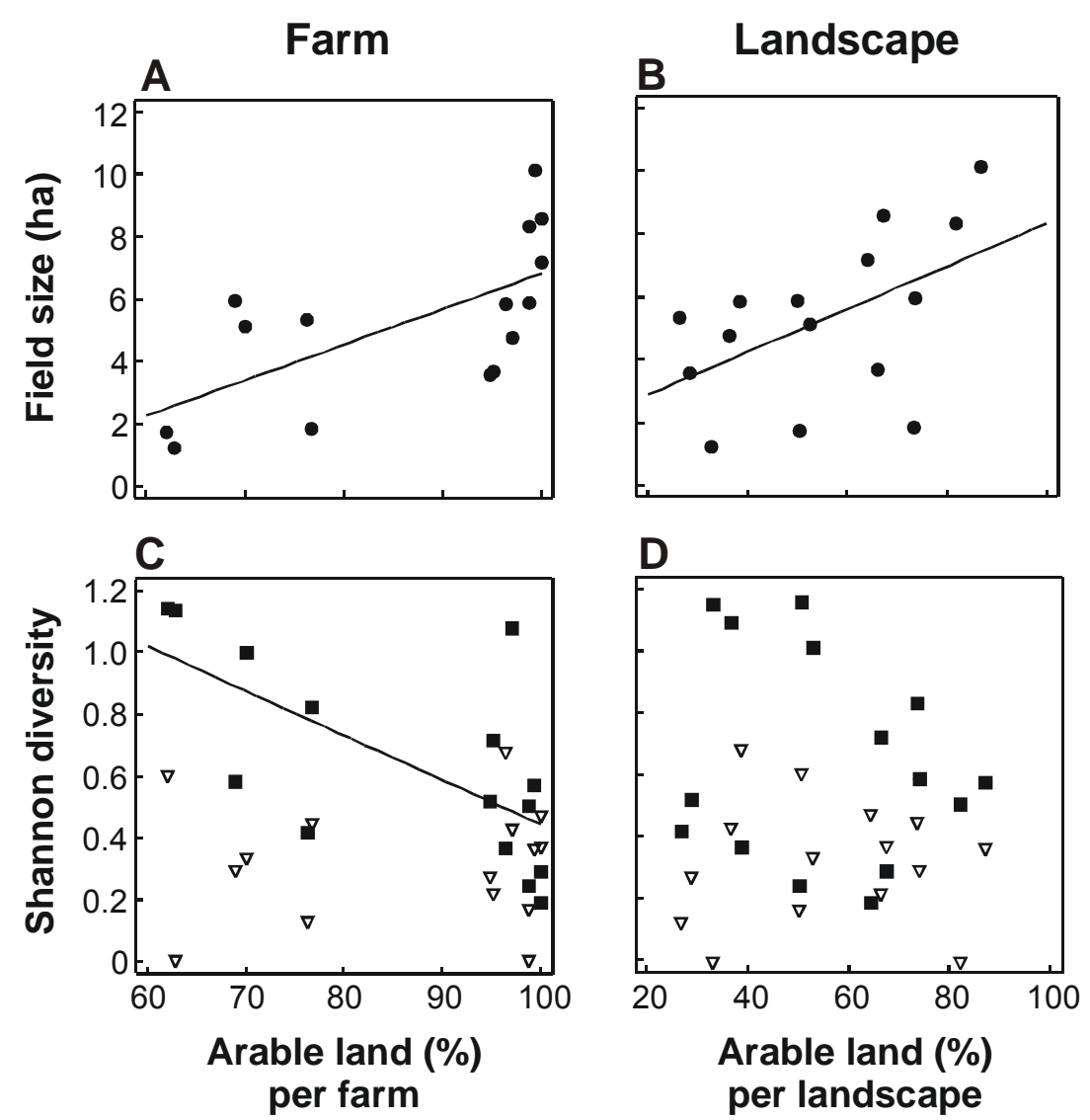

Figure 2. Field size and Shannon diversity of crop species in relation to the proportion of arable land on a farm and a landscape scale. (A) Relationship between the field size (ha) and the proportion of arable land per farm $(\%) ; P=0.008$. (B) Relationship between the field size (ha) and the proportion of arable land per landscape (\%); $P=0.048$; not significant in multiple regression analysis. (C) Relationship between the Shannon diversity of cultivated crop species (cereals and dicots) and the proportion of arable land per farm (\%); cereals: $P=0.008$, dicots: $P=0.829$. (D) Relationship between the Shannon diversity of cultivated crop species (cereals and dicots) and the proportion of arable land per landscape (\%); cereals: $P=0.499$; dicots: $P=0.953$. Points $=$ cereals + dicots, squares $=$ cereals, triangles $=$ dicots.

The mean amount of nitrogen fertiliser applied to annual crops was $166.0 \pm 18.3 \mathrm{~kg} \mathrm{~N} / \mathrm{ha}$ and varied between $140 \mathrm{~kg} \mathrm{~N} / \mathrm{ha}$ and $200 \mathrm{~kg} \mathrm{~N} / \mathrm{ha}$. The mean amount was higher in cereals $(187.1 \pm 22.4 \mathrm{~kg} \mathrm{~N} / \mathrm{ha}$; min.: $140 \mathrm{~kg} \mathrm{~N} / \mathrm{ha}$; $\max .: 225 \mathrm{~kg} \mathrm{~N} / \mathrm{ha})$ than in dicots $(134.1 \pm 28.2 \mathrm{~kg}$ $\mathrm{N} /$ ha; min.: $75 \mathrm{~kg} \mathrm{~N} / \mathrm{ha}$; max.: $180 \mathrm{~kg} \mathrm{~N} / \mathrm{ha}$ ). The amount of nitrogen fertiliser was not correlated with the proportion of arable land per farm, but with the proportion of arable land per landscape in the cereal crop species (Fig. 3a and b). The mean cereal yields were $8.6 \pm 2.9 \mathrm{t} / \mathrm{ha}$ and similar in the different species, except maize (Table 2). The yields of dicots

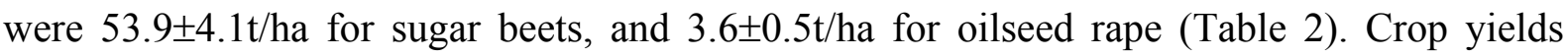
were positively correlated with the proportion of arable land both per farm and/or per landscape, but only for winter wheat $\left(F=11.67, P=0.002, \quad R^{2}=66.053 \%, \quad Y=\right.$ 48.804 $+0.294 \times$ arable land (\%) per farm $+0.154 \times$ arable land (\%) per landscape) and winter barley $\left(F=4.99, P=0.047, R^{2}=31.207 \%, Y=42.518+0.373 \times\right.$ arable land (\%) per farm), while 
the variability of yields of all other crop species was not related with farm specialisation and/or landscape complexity (Fig. 3c and d).
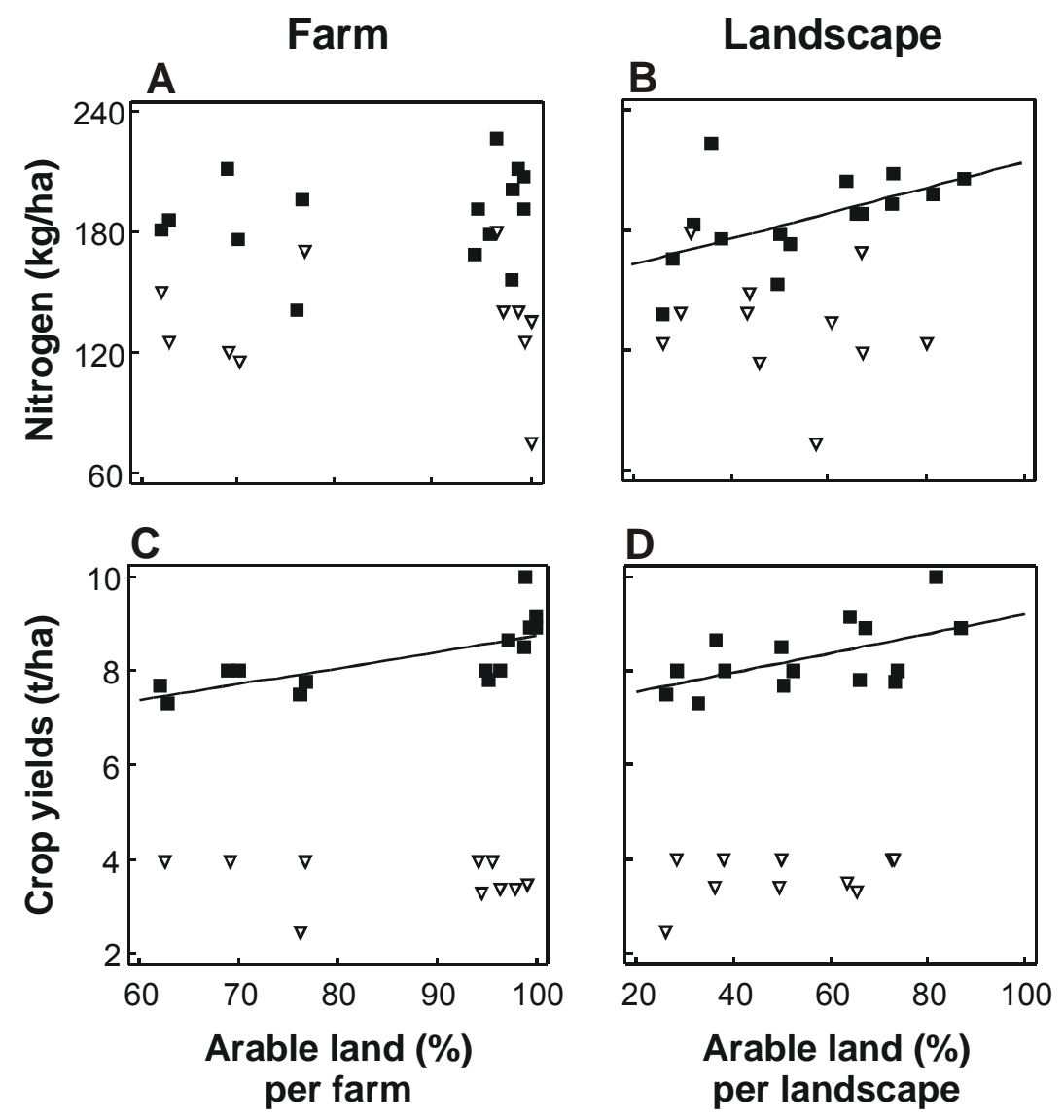

Figure 3. Nitrogen fertilisation and crop yields in relation to the proportion of arable land on a farm and a landscape scale. (A) Relationship between the amount of nitrogen fertiliser ( $\mathrm{kgN} / \mathrm{ha}$ ) to cereals and dicots and the proportion of arable land per farm (\%); cereals: $P=0.465$; dicots: $P=0.863$. (B) Relationship between the amount of nitrogen fertiliser ( $\mathrm{kgN} / \mathrm{ha}$ ) to cereals and dicots and the proportion of arable land per landscape (\%); cereals: $P=0.029$; dicots: $P=0.493$. (C) Relationship between crop yields ( $\mathrm{t} / \mathrm{ha}$ ) of cereals (winter wheat) and dicots (oilseed rape) and the proportion of arable land per farm (\%); winter wheat: $P=0.004$; oilseed rape: $P=$ 0.664. (D) Relationship between crop yields ( $\mathrm{t} / \mathrm{ha}$ ) of cereals (winter wheat) and dicots (oilseed rape) and the proportion of arable land per landscape (\%); winter wheat: $P=0.030$; oilseed rape: $P=0.308$. Squares $=$ cereals (or winter wheat, respectively), triangles $=$ dicots (or oilseed rape, respectively).

The mean number of pest species per crop was $4.0 \pm 1.6$ for weeds, $1.9 \pm 1.0$ for pathogens, and $1.8 \pm 0.8$ for insects. The mean number of pesticide applications per crop was $2.1 \pm 0.6$ for herbicides, $1.3 \pm 0.7$ for fungicides, and $1.1 \pm 0.5$ for insecticides. Numbers of problematic pest species did not differ between cereal and dicot crop species in the weeds $(4.1 \pm 1.8$ vs. $4.0 \pm 1.9)$, but in the pathogens $(2.5 \pm 1.1$ vs. $1.1 \pm 1.2)$ and pest insects $(1.1 \pm 0.6 v s .2 .7 \pm 1.3)$, which were higher or lower in cereals, respectively. Pesticide applications did not differ between cereal and dicot crop species in the use of herbicides $(2.0 \pm 0.7$ vs. $2.2 \pm 0.8)$ and insecticides ( $1.0 \pm 0.7 v s .1 .4 \pm 0.6)$, but in the use of fungicides (1.8 $\pm 0.8 v s .0 .6 \pm 0.6$, Table 3$)$. The mean number of problematic weed species as well as the mean number of herbicide 
applications were neither related with the proportion of arable land per farm nor per landscape (Fig. 4a and b; Fig. 5a and b). The mean number of pathogen species in cereals increased as the proportion of arable land per farm increased indicating pathogen problems induced by farm specialisation (Fig. 4c and d). However, mean number of fungicide applications did not increase with the proportion of arable land per farm ( $5 \mathrm{c}$ and $\mathrm{d})$. The mean number of problematic pest insect species did not decrease with the proportion of arable land per landscape (Fig. 4e and f), whereas the mean number of insecticide applications in dicots decreased (Fig. 5e and f).

Table 3. Number of pest species and pesticide applications in annual crops in 15 landscape sectors.

\begin{tabular}{|c|c|c|c|}
\hline & Mean \pm SD & Minimum & Maximum \\
\hline \multicolumn{4}{|c|}{ Monocots (cereals): } \\
\hline \multicolumn{4}{|c|}{ Number of problematic species } \\
\hline Weeds & $4.1 \pm 1.8$ & 2.0 & 8.0 \\
\hline Pathogens & $2.5 \pm 1.1$ & 0.7 & 4.0 \\
\hline Insects & $1.1 \pm 0.6$ & 0.3 & 2.0 \\
\hline \multicolumn{4}{|c|}{ Number of pesticide applications } \\
\hline Herbicides & $2.0 \pm 0.7$ & 0.8 & 3.5 \\
\hline Fungicides & $1.8 \pm 0.8$ & 0.9 & 4.0 \\
\hline Insecticides & $1.0 \pm 0.7$ & 0.2 & 3.0 \\
\hline \multicolumn{4}{|c|}{ Dicots (rape; beets): } \\
\hline \multicolumn{4}{|c|}{ Number of problematic species } \\
\hline Weeds & $4.0 \pm 1.9$ & 1.0 & 8.0 \\
\hline Pathogens & $1.1 \pm 1.2$ & 0.0 & 4.0 \\
\hline Insects & $2.7 \pm 1.3$ & 0.5 & 5.0 \\
\hline \multicolumn{4}{|c|}{ Number of pesticide applications } \\
\hline Herbicides & $2.2 \pm 0.8$ & 1.0 & 4.0 \\
\hline Fungicides & $0.6 \pm 0.6$ & 0.0 & 1.5 \\
\hline Insecticides & $1.4 \pm 0.6$ & 0.5 & 2.5 \\
\hline
\end{tabular}



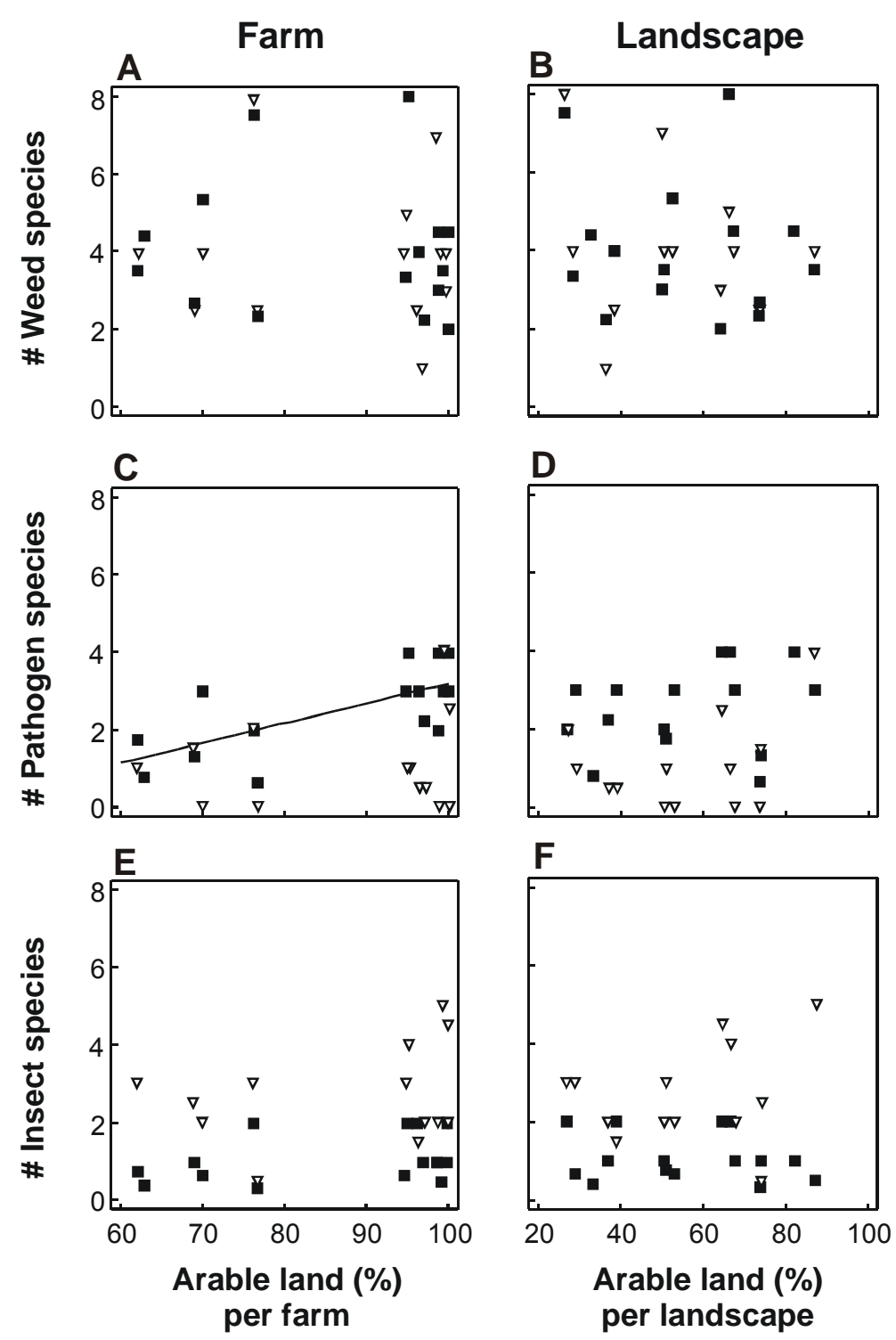

Figure 4. Numbers of problematic pest species in relation to the proportion of arable land on a farm and a landscape scale. (A) Relationship between the number of problematic weed species in cereals and dicots and the proportion of arable land per farm (\%); cereals: $P=0.720$; dicots: $P=0.883$. (B) Relationship between the number of problematic weed species in cereals and dicots and the proportion of arable land per landscape (\%); cereals: $P=0.559$; dicots: $P=0.429$. (C) Relationship between the number of problematic pathogen species in cereals and dicots and the proportion of arable land per farm (\%); cereals: $P=0.004$; dicots: $P=0.638$. (D) Relationship between the number of problematic pathogen species in cereals and dicots and the proportion of arable land per landscape (\%); cereals: $P=0.362$; dicots: $P=0.296$. (E) Relationship between the number of problematic insect species in cereals and dicots and the proportion of arable land per farm (\%); cereals: $P=$ 0.199; dicots: $P=0.381$. (F) Relationship between the number of problematic insect species in cereals and dicots and the proportion of arable land per landscape (\%); cereals: $P=0.535$; dicots: $P=0.405$. Squares $=$ cereals, triangles $=$ dicots. 

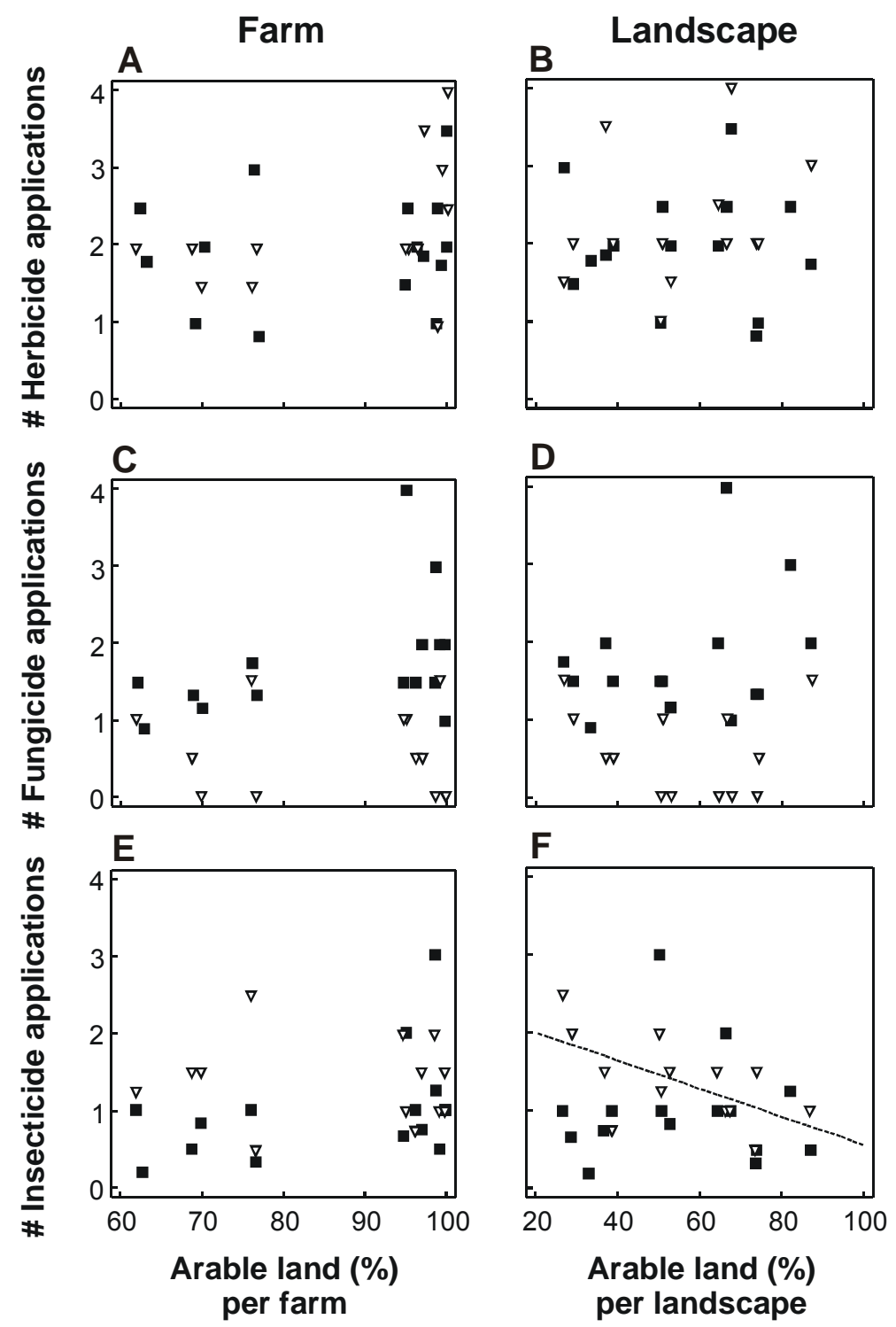

Figure 5. Numbers of pesticide applications in relation to the proportion of arable land on a farm and a landscape scale. (A) Relationship between the number of herbicide applications per year in cereals and dicots and the proportion of arable land per farm (\%); cereals: $P=0.632$; dicots: $P=0.140$. (B) Relationship between the number of herbicide applications per year in cereals and dicots and the proportion of arable land per landscape (\%); cereals: $P=0.775$; dicots: $P=0.343$. (C) Relationship between the number of fungicide applications per year in cereals and dicots and the proportion of arable land per farm (\%); cereals: $P=0.102$; dicots: $P=0.776$. (D) Relationship between the number of fungicide applications per year in cereals and dicots and the proportion of arable land per landscape (\%); cereals: $P=0.232$; dicots: $P=0.564$. (E) Relationship between the number of insecticide applications per year in cereals and dicots and the proportion of arable land per farm (\%); cereals: $P=$ 0.120; dicots: $P=0.788$. (F) Relationship between the number of insecticide applications per year in cereals and dicots and the proportion of arable land per landscape (\%); cereals: $P=0.971$; dicots: $P=0.026$. Squares $=$ cereals, triangles $=$ dicots. 


\section{Discussion}

Our results showed that landscape complexity as well as farm specialisation were related to many, but not all indicators of land-use intensity. Both landscape complexity and farm specialisation were characterised by the proportion of arable land per landscape or farm, respectively, but these two predictor variables were not correlated. Farms with high percentages of annual crops had reduced crop-species diversity, larger fields, higher crop yields and more pathogen species. Landscapes with high percentages of annual crops were related to larger fields, more nitrogen input and higher crop yields. However, the generally expected pesticide-use gradient from simple to complex landscapes and from big farms that are specialised on annual crops to small live stock farms did not hold for our landscapes in northern Germany. Accordingly, generalisations such as "simply structured landscapes as well as farms specialised on annual crops show increased land-use intensity" may be misleading. Moreover, the results support our former findings in the identical landscapes that the enhanced habitat diversity and the many refuges for natural enemies in complex landscapes play a dominant role for biodiversity, pollination of bees and biocontrol of rape pollen beetles (Thies and Tscharntke, 1999; Steffan-Dewenter et al., 2001, 2002).

\section{Farm specialisation and landscape complexity}

Analysed farms were exceptionally big (ca. 181ha) compared to the average farm size in Germany (ca. 32ha) or the average farm size in the European community (ca. 18ha) (BMELF, 2000). Bigger farms showed a specialisation towards annual crops and smaller farms towards stock farming of cattle. This clearly indicates an optimisation of production factors at the farm scale to "labour-intensive" rearing of cattle in smaller farms and "capital-intensive" cultivation of annual, economically attractive crops in bigger farms in our region (southern Lower Saxony). In this region, a structural change in the last decades led to the abandonment of many farms, which were taken over by other, more successful farms ("grow or perish"), thereby also changing the geographical position of fields (BMELF, 2000). While they used to be more or less grouped around the farm buildings, they can be situated a far way from each other nowadays. Hence, these structural processes weakened the formerly close relation of farm and landscape. This may also explain why farm specialisation was not related to landscape structure in our study region. However, this independency made it possible to statistically analyse the relative impact of these two parameters on land-use intensity. In contrast, Thenail (2002) found a connection between farming systems and landscape structure in Brittany (France), although this process of farm growing also occurred in this region. She found that the production, economic levels, productivity and modernisation of technical means of dairy farms along a gradient of hedgerow density increased from high-density to low-density hedgerow areas. 


\section{Field sizes and crop diversity}

Specialisation of bigger farms towards annual crops was associated with larger field sizes. The mean field size in "annual crop farms" (ca. 6ha) was nearly three times higher than those of less specialised farms indicating that bigger farms optimise their production at the field scale. Larger fields allow more effective use of (big) machines, which results in lower production costs per ha (Haber and Salzwedel, 1992). However, the trade-off between economic and ecological goals is obvious, because smaller fields provide more field margins, which are known to be of ecological importance in these landscapes (Thies et al., 2000) and elsewhere (e.g. Chiverton and Sotherton, 1991; Heitzmann et al., 1992; Lagerlöf et al., 1992; Dennis et al., 1994; Pfiffner and Luka, 2000; Nicholls et al., 2001; Varchola and Dunn, 2001). Although fields tended to be larger in structurally simple landscapes, only farm specialisation (i.e., the proportion of arable land per farm) was a significant predictive factor of field sizes (in a multiple regression analysis). Therefore, farm specialisation may be the driving force for the proportion of field margins and field shape complexity. Furthermore, specialisation of bigger farms towards annual crops was associated with lower crop species diversity. Annual crop farmers mainly produce wheat, barley, sugar beets, and oilseed rape for the market, but do not cultivate feed crops like oats, triticale, or feed beets. Consequently, they might not be expected to contribute to a diverse within-field wild flora (and fauna), which is known to change with each cultivated crop species (Ellenberg, 1996; Hofmeister and Garve, 1998).

\section{Yields, fertilisation, and pesticides}

High yields in agriculture depend on addition of fertilisers, especially nitrogen. The mean cereal yields of $8.6 \mathrm{t} / \mathrm{ha}$ were higher than the average cereal yields in the European Union (5.7t/ha; European Commission, 2001), USA (5.9t/ha; FAO, 2001), and the world (3.1t/ha; FAO, 2001). The mean amount of nitrogen fertilisers was also on a high level of ca. $170 \mathrm{~kg}$ $\mathrm{N} / \mathrm{ha}$. Farmers clearly differentiated between cereals (ca. $187 \mathrm{~kg} \mathrm{~N} / \mathrm{ha}$ ) and dicots (ca. $134 \mathrm{~kg}$ $\mathrm{N} / \mathrm{ha}$ ) following the recommendations of official advisory boards (e.g. Pflanzenschutzamt Hannover, 2002). Farm specialisation was not related to nitrogen fertilisation, but farmers increased the amount of nitrogen fertiliser in cereals in structurally simple landscapes. Consequently, cereal yields, which are often up to 10t/ha, increased with a high proportion of arable land per landscape. However, cereal yields additionally increased with increasing proportion of arable land per farm indicating annual crop farmers to have expertise in realising higher yields.

Although cereal monocultures are known to have problems with some weed, pathogen, and insect species, which appear in large quantities and need to be controlled with pesticides (Christen and Sieling, 1993; Heitefuss et al., 1993; Hofmeister and Garve, 1998; Heitefuss, 2000), the number of problematic pest species (weeds, pathogens, pest insects) as well as the number of applications of pesticides (herbicides, fungicides, insecticides) could not be related to farm specialisation or landscape complexity. Only the number of insecticide applications in 
dicotyledonous crops increased with landscape complexity - even though the number of problematic pest insect species did not seem to be higher in complex landscapes. According to several studies, natural enemies of insect pests are more effective in structurally complex landscapes (Kareiva and Wennergren, 1995; Roland and Taylor, 1997; Menalled et al. 1999; Thies and Tscharntke, 1999), so this result was unexpected and suggests that such findings are little related to control practices. As expected, the number of pathogen species in monocotyledonous crops increased with increasing proportion of arable land per farm indicating pathogen problems due to farm specialisation. This pattern is well known by plant protection professionals predicting pathogen pests to be more abundant within large areas of monocots (Heitefuss, 2000), but may also be expected to depend on a higher sensitivity of cereal farmers to plant diseases. These farmers might be able to identify more species and to better calculate reasonableness of pesticide applications.

\section{Conclusion}

In conclusion, our results give evidence that both the local scale of farm specialisation as well as the regional scale of landscape complexity are important for the prediction of land-use intensity. Farms specialised to the cultivation of annual crops showed larger field sizes, a lower diversity of crop species, and increasing cereal yields, whereas complex landscapes were related to decreasing nitrogen fertilisation as well as lower cereal yields. So, landscape complexity and farm specialisation revealed to be indicators for several parameters of landuse intensity, but, in contrast to expectations, not of pesticide use. Despite this inconsistency, the complex landscapes have been shown to provide high biodiversity of important functional groups such as pollinating bees and biocontrol agents. This is why agri-environmental schemes should not only focus on the farm level, but also on the landscape level. As this study is regionally restricted to northern Germany, which is obviously different to other European regions (e.g. Brittany, Thenail, 2002), further studies on the relation of land-use intensity to landscape and farm characteristics are needed.

\section{Acknowledgements}

We thank the farmers for giving information on their farms and land-use practices, Ingo Bräuer, Felix Herzog, David Kleijn and two anonymous reviewers for helpful comments on the manuscript, the Federal Ministry of Education and Research (Bundesministerium für Bildung und Forschung) and the German Science Foundation (Deutsche Forschungsgemeinschaft) for financial support. 


\section{References}

Bundesministerium für Ernährung, Landwirtschaft und Forsten (BMELF), 2000. Agrarbericht der Bundesregierung 2000. Referat Öffentlichkeitsarbeit, Bonn.

Cadenasso, M.L., Pickett, S.T.A., 2000. Linking forest edge structure to edge function: mediation to herbivore damage. J. Ecol. 88, 31-44.

Chiverton, P.A., Sotherton, N.W., 1991. The effects on beneficial arthropods of the exclusion of herbicides from cereal crop edges. J. Appl. Ecol. 28, 1027-1039.

Christen, O., Sieling, K., 1993. The effect of different preceding crops on the development, growth and yield of winter barley. J. Agron. Crop. Sci. 171, 114-123.

Dennis, P., Thomas, M.B., Sotherton, N.W., 1994. Structural features of field boundaries which influence the overwintering densities of beneficial arthropod predators. J. Appl. Ecol. 31, 361-370.

Ellenberg, H., 1996. Vegetation Mitteleuropas mit den Alpen in ökologischer, dynamischer und historischer Sicht. 5. Edition, Ulmer, Stuttgart.

European Commission, Head Office, 2001. Die Landwirtschaft in der Europäischen Union Statistische und wirtschaftliche Informationen 2000, http://europa.eu.int/comm/ agriculture/agrista/2000/table_de/agri.pdf

Food and Agriculture Organization of the United Nations - United Nations Educational, Scientific and Cultural Organization (FAO-UNESCO), 1990. Soil map of the world Revised Legend, Rome.

Food and Agriculture Organization of the United Nations (FAO), 2001. FAO Statistical Databases, http://apps.fao.org/

Geries Ingenieure, 2002. Agrarstrukturelle Entwicklungsplanung (AEP) Göttingen und Umland. http://www.aep-goettingen-umland.geries.de/aepbericht/bericht.pdf

Gonzalez, A., Lawton, J.H., Gilbert, F.S., Blackburn, T.M., Evans-Freke, I., 1998. Metapopulation dynamics, abundance, and distribution in a microecosystem. Science 281, 2045-2047

Haber, W., Salzwedel, J., 1992. Umweltprobleme der Landwirtschaft - Sachbuch Ökologie. J. B. Metzlersche Verlagsbuchhandlung und Carl Ernst Poeschel Verlag, Stuttgart.

Heitefuss, R., 2000. Pflanzenschutz: Grundlagen der praktischen Phytomedizin. 3. Edition, Thieme, Stuttgart.

Heitefuss, R., König, K., Obst, A., Reschke, M., 1993. Pflanzenkrankheiten und Schädlinge im Ackerbau. 3. Edition, DLG-Verlag, Frankfurt (Main); BLV-Verl.-Ges., München; Landwirtschaftsverlag, Münster-Hiltrup.

Heitzmann, A., Lys, J.A., Nentwig, W., 1992. Nützlingsförderung am Rand - oder: Vom Sinn des Unkrautes. Landwirtsch. Schweiz 5, 25-36.

Hofmeister, H., Garve, E., 1998. Lebensraum Acker. 2. Edition, Parey, Berlin.

Hunter, M.D., 2002. Landscape structure, habitat fragmentation, and the ecology of insects. Agric. For. Entomol. 4, 159-166. 
Kareiva, P., 1990. Population dynamics in spatially complex environments: theory and data. Phil. Trans. R. Soc. Lond. B 330, 175-190.

Kareiva, P., Wennergren, U., 1995. Connecting landscape patterns to ecosystem and population processes. Nature 373, 299-302.

Kleijn, D., Berendse, F., Smit, R., Gilissen, N., 2001. Agri-environment schemes do not effectively protect biodiversity in Dutch agricultural landscapes. Nature 413, 723-725.

Krebs, J.R., Wilson, J.D., Bradbury, R.B., Siriwardena, G.M., 1999. The second silent spring? Nature 400, 611-612.

Lagerlöf, J., Stark, J., Svensson, B., 1992. Margins of agricultural fields as habitats for pollinating insects. Agric. Ecosyst. Environ. 40, 117-124.

Mander, Ü., Mikk, M., Külvik, M., 1999. Ecological and low intensity agriculture as contributors to landscape and biological diversity. Landscape Urban Plann. 46, 169-177.

Marggraf, R., Streb, S., 1997. Ökonomische Bewertung der natürlichen Umwelt: Theorie, politische Bedeutung, ethische Diskussionen. Spektrum Akademischer Verlag, Heidelberg.

Matson, P.A., Parton, W.J., Power, A.G., Swift, M.J., 1997. Agricultural intensification and ecosystem properties. Science 277, 504-509.

McLaughlin, A., Mineau, P., 1995. The impact of agricultural practices on biodiversity. Agric. Ecosyst. Environ. 55, 201-212.

Menalled, F.D., Marino, P.C., Gage, S.H., Landis, D.A., 1999. Does agricultural landscape structure affect parasitism and parasitoid diversity? Ecol. Appl. 9, 634-641.

Nicholls, C.I., Parrella, M., Altieri, M.A., 2001. The effects of a vegetational corridor on the abundance and dispersal of insect biodiversity within a northern California organic vineyard. Landscape Ecol. 16, 133-146.

Niedersächsisches Landesamt für Bodenforschung, 1997. NIBIS. Digitale Bodenübersichtskarte 1:50000. Hannover.

Pfiffner, L., Luka, H., 2000. Overwintering of arthropods in soils of arable fields and adjacent semi-natural habitats. Agric. Ecosyst. Environ. 78, 215-222.

Pflanzenschutzamt Hannover, 2002. Pflanzenbau und Pflanzenschutz - Empfehlungen 2002/2003. Diaprint, Hannover.

Pickett, S.T.A., Cadenasso, M.L., 1995. Landscape ecology: spatial heterogeneity in ecological systems. Science 269, 331-334.

Polis, G.A., Anderson, W.B., Holt, R.A., 1997. Toward an integration of landscape and food web ecology: the dynamics of spatially subsidized food webs. Annu. Rev. Ecol. Syst. $28,289-316$.

Ricketts, T.H., 2001. The matrix matters: Effective isolation in fragmented landscapes. Am. Nat. 158, 87-99.

Roland, J., Taylor, P.D., 1997. Insect parasitoid species respond to forest structure at different spatial scales. Nature 386, 710-713. 
Sokal, R.R., Rohlf, F.J., 1995. Biometry, 3. Edition, Freeman \& Company, New York.

Steffan-Dewenter, I., Münzenberg, U., Tscharntke, T., 2001. Pollination, seed set and seed predation on a landscape scale. Proc. R. Soc. Lond. B. 268, 1685-1690.

Steffan-Dewenter, I., Münzenberg, U., Bürger, C., Thies, C., Tscharntke, T., 2002. Scaledependent effects of landscape structure on three pollinator guilds. Ecology 83, 14211432 .

Thenail, C., 2002. Relationships between farm characteristics and the variation of the density of hedgerows at the level of a micro-region of bocage landscape. Study case in Brittany, France. Agric. Syst. 71, 207-230.

Thenail, C., Baudry, J., 2004. Variation of farm spatial land use pattern according to the structure of the hedgerow network (bocage) landscape: a case study in northeast Brittany. Agric. Ecosyst. Environ. 101, 53-72.

Thies, C., Tscharntke, T., 1999. Landscape structure and biological control in agroecosystems. Science 285, 893-895.

Thies, C., Denys, C., Tscharntke, T., 2000. Die Förderung der biologischen Schädlingsbekämpfung durch Ackerrandstreifen und Ackerbrachen. In: Nentwig, W. (Ed.), Streifenförmige ökologische Ausgleichsflächen in der Kulturlandschaft: Ackerkrautstreifen, Buntbrache, Feldränder. Verlag Agrarökologie, Bern, pp. 219-227.

Thies, C., Steffan-Dewenter, I., Tscharntke, T., 2003. Effects of landscape context on herbivory and parasitism at different spatial scales. Oikos 101, 18-25.

Tilman, D., Fargione, J., Wolff, B., D’Antonio, C., Dobson, A., Howarth, R., Schindler, D., Schlesinger, W.H., Simberloff, D., Swackhamer, D., 2001. Forecasting agriculturally driven global environmental change. Science 292, 281-284.

Tilman, D., Cassman, K.G., Matson, P.A., Naylor, R., Polasky, S., 2002. Agricultural sustainability and intensive production practices. Nature 418, 671-677.

Tischendorf, L., Fahrig, L., 2000. On the usage and measurement of landscape connectivity. Oikos 90, 7-19.

Turner, M.G., Gardner, R.H., 1991. Quantitative methods in landscape ecology. SpringerVerlag, New York.

Varchola, J.M., Dunn, J.P., 2001. Influence of hedgerow and grassy field borders on ground beetle (Coleoptera: Carabidae) activity in fields of corn. Agric. Ecosyst. Environ. 83, 153-163.

Wiegand, T., Moloney, K.A., Naves, J., Knauer, F., 1999. Finding the missing link between landscape structure and population dynamics: a spatially explicit perspective. Am. Nat. $154,605-627$. 


\section{Chapter 3}

\section{The effects of landscape complexity on arable weed species diversity in organic and conventional farming}

Indra Roschewitz, Doreen Gabriel, Teja Tscharntke \& Carsten Thies Journal of Applied Ecology, in press

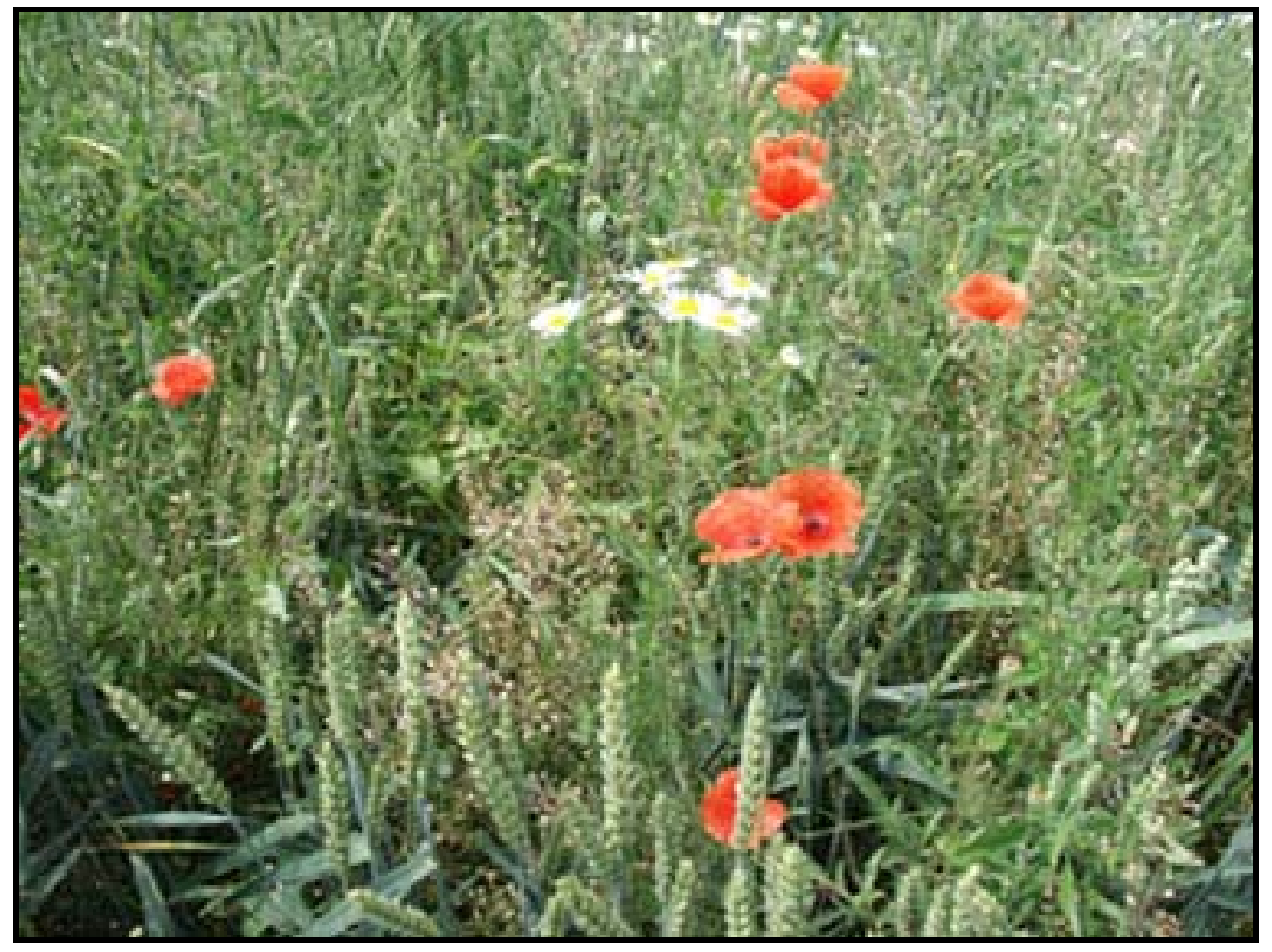




\section{Abstract}

1. There is growing concern about declining species diversity in agroecosystems, caused by agricultural intensification at the field and the landscape scale. Species diversity of arable weeds is classically related to local abiotic factors and resource conditions. It has been suggested to be enhanced by organic farming, but the surrounding landscape may also be important.

2. This study assesses the weed vegetation in 24 winter wheat fields, combined with seed rain and seedbank analyses, to examine the relative importance of organic vs. conventional farming and landscape complexity for weed species diversity. Diversity was partitioned into its additive components alpha, beta, and gamma diversity. Percent arable land in a circular landscape sector of $1 \mathrm{~km}$ radius around each study site was used as indicator for landscape complexity.

3. Weed species diversity in the vegetation, the seed rain and the seedbank was higher in organic than in conventional fields. Increasing landscape complexity enhanced species diversity in the vegetation of conventional, but little of organic fields, resulting in nearly similar diversity in both farming systems when the landscape was complex. Species diversity of the seedbank was increased by landscape complexity irrespective of farming system.

4. Overall diversity was greatly determined by the high heterogeneity between and within the fields (beta diversity). Higher weed species diversity in complex landscapes and/or organic farming could only in very few cases be related to particular species depending on such landscapes or farming system.

5. Synthesis and applications. Local weed species diversity was influenced by both landscape complexity and farming system. Species diversity in organic farming was clearly higher only in simple landscapes, because the conventional vegetation reached similar diversity levels when the surrounding landscape was complex, providing refuges for weed populations. Consequently, agri-environment schemes to preserve and enhance biodiversity should not only consider the management of single fields, but also of the surrounding landscape.

\section{Key words}

Additive partitioning, beta diversity, biodiversity, conservation, seedbank, seed rain, winter wheat. 


\section{Introduction}

Species richness in agroecosystems dramatically declined during the last decades, mainly due to the intensification of land-use practices (Krebs et al. 1999; Tilman et al. 2002). On the one hand, intensification occurred at the field scale through the intensive use of pesticides and mineral fertilizers. On the other hand, it also occurred at the landscape scale, due to the aggregation of intensively managed arable fields as well as to land consolidations which resulted in a transformation of formerly complex landscapes with relatively high proportions of (semi-)natural habitats to simple landscapes dominated by arable fields.

Annual crop fields are characterised by a high frequency and intensity of disturbances. Organisms have to adapt to these disturbances or recolonise the fields afterwards. Organic farming is expected to maintain higher species richness as pesticides are not applied in this farming system. As a general rule, species richness of the aboveground vegetation (Moreby et al. 1994; Hald 1999; Menalled, Gross \& Hammond 2001; Hyvönen et al. 2003), the seedbank (Menalled et al. 2001), and several groups of arthropods (e.g., Letourneau \& Goldstein 2001; Hutton \& Giller 2003) have been reported to be higher in organic and extensive than conventional farms. However, several studies found no effects of farming system on species richness of plants (Weibull, Östman \& Granqvist 2003) and arthropods (Kleijn et al. 2001; Weibull et al. 2003).

Arable fields in complex landscapes should also harbour higher species richness than in simple landscapes as complex landscapes may provide alternative habitats and thereby sources for a recolonisation of fields. The relation between local species richness and landscape context has been addressed for several groups of arthropods (e.g., Menalled et al. 1999; Krauss, Steffan-Dewenter \& Tscharntke 2003; Schmidt et al. 2005), but only Weibull et al. (2003) and Krauss et al. (2004) investigated this relationship for plants in agricultural landscapes. However, they did not detect an effect of landscape context on plant species richness. Holl \& Crone (2004) found only weak importance of landscape-scale variables for the diversity of native riparian understorey plants. Despite these findings, the species diversity of weeds in annual crop fields should depend on both local management and surrounding landscape, as the weeds are a highly dynamic group adapted to a frequently disturbed habitat, relying on their seedbank as well as on immigration of seeds through the seed rain from surrounding habitats. Thereby, weed species diversity in conventional fields should especially benefit from the landscape as these are more frequently disturbed (e.g. by herbicide use) than organic fields. Knowledge on these relations is crucial for a better understanding of weed species diversity patterns and should be helpful for future conservation management decisions. However, to our knowledge, this is the first study analysing how species diversity of arable weeds in the vegetation, seed rain, and seedbank respond to the surrounding landscape in organic and conventional fields. In addition, the contribution of the heterogeneity in community composition between weed samples - within and between fields - to field and 
to regional diversity is little known. The concept of additive partitioning of species (Allan 1975; Lande 1996) addresses this problem by dividing total diversity of a given number of samples (gamma diversity) into the additive components alpha (mean diversity) and beta (between sample heterogeneity) thereby allowing to scale up the species diversity at several spatial scales up to whole regions (e.g., Wagner, Wildi \& Ewald 2000; Gering \& Crist 2002; Crist et al. 2003; Gering, Crist \& Veech 2003).

In this study, we used this concept to characterise the diversity of arable weeds at two spatial scales. At the regional scale, gamma diversity is the overall number of species found in our study region. Alpha diversity is the average number of species of the studied fields within the region, while beta diversity accounts for the within-region heterogeneity (average number of species not found in a field). At the field scale, gamma diversity is the overall number of species found in the samples of one field. Alpha diversity is the average number of species found in the samples of one field, and beta diversity accounts for the within-field heterogeneity (average number of species not found in a sample). At both scales, the relative beta diversity (the percentage of beta contributing to gamma) was also calculated. We analysed the relative importance of local management (organic vs. conventional) and landscape complexity (gradient from simple to complex) on species diversity of arable weeds in the vegetation, the seed rain, and the seedbank (at the field scale) of 24 winter wheat fields. We hypothesised that the field scale alpha, beta, and gamma diversity of weeds should be higher in organic than in conventional fields and in complex than in simple landscapes, and tested the idea that landscape complexity may compensate for the reduced diversity in conventional fields. In contrast, the relative within-field heterogeneity, beta (\%), was expected to be higher in conventional fields, because these fields should have a low alpha diversity and, consequently, the relative contribution of beta to gamma diversity should be high. In particular, we expected that several species (e.g. threatened species of the Red List of Lower Saxony, Germany (Garve \& Letschert 1991; Garve 1993; Korneck, Schnittler \& Vollmer 1996)) which are more susceptible to disturbances than common species would especially profit from organic farming and/or from a certain degree of landscape complexity (Korneck \& Sukopp 1988; Jedicke 1997; Hofmeister \& Garve 1998). 


\section{Material and methods}

\section{STUDY AREA AND ANALYSIS OF LANDSCAPE COMPLEXITY}

The study was conducted in the year 2002 in 12 agricultural landscapes around the city of Göttingen (North Germany). This area covers approx. $1350 \mathrm{~km}^{2}$ and is dominated by an arable land-grassland mosaic covering about $75 \%$ of the region, while the remaining area is characterised by patchily distributed fragments of near-natural and semi-natural habitats such as forests, fallows, field margins, and hedgerows. We selected the 12 landscapes along a gradient of landscape complexity ranging from very simple landscapes with high percentage of arable land ( $\sim 95 \%)$ to complex landscapes with less percentage of arable land $(\sim 30 \%)$. These complex landscapes exhibit large areas of non-crop habitats such as field margins, fallows, grassland, and garden land, which should be potential weed habitats. All landscapes were at least $3 \mathrm{~km}$ (from centre to centre) away from each other. In the centre of each landscape, we selected a pair of one conventionally and one organically (according to European Union Regulation 2092/91/EEC) managed winter wheat field located close to each other $(<400 \mathrm{~m})$ as study sites. The organic fields were under organic management for at least 7 years.

Landscape complexity was measured around each studied field in a circular landscape sector of $1 \mathrm{~km}$ radius. Official digital thematic maps (ATKIS - Digitales Landschaftsmodell 25/1; Landesvermessung und Geobasisinformation, Hannover, Germany, 1991-1996) and the Geographical Information System ArcView 3.1 (ESRI Geoinformatik GmbH, Hannover, Germany) were used to determine the area of arable land, perennial grassland, forests, hedgerows, garden land, and settlement in each landscape sector. The percentage of arable land per landscape was considered as indicator for landscape complexity, because it is related to other important landscape metrics such as habitat-type diversity after Shannon-Wiener $(F=$ 124.12; $P<0.001 ; R=-0.80)$ and perimeter-to-area ratio $(F=61.28 ; P<0.001 ; R=-0.69)$. In the studied landscapes, arable land was the predominant land-use type, covering $63 \pm 22 \%$ of the total area (arithmetic mean \pm standard deviation, min.: 30\%, max.: 95\%). The mean size of the study fields was $3.5 \pm 1.7$ ha (arithmetic mean \pm standard deviation), and was neither related to landscape complexity (linear regression: $R=0.29 ; P=0.17$ ) nor to farming system (paired t-test: $t=1.3, P=0.21$ ). All fields were bordered by old grassy margins that were 1 $3 \mathrm{~m}$ wide and mowed once per year. The majority of adjacent crops for both field types were conventional winter cereals. In organic fields, winter wheat was grown after a mixture of clover and grass, while the preceding crops of conventional winter wheat were mostly winter wheat and oilseed rape.

Local abiotic factors such as soil quality and factors of land-use intensity such as nitrogen fertilisation and herbicide use are known to be important determinants of local arable weed species diversity (e.g., Grime 1979; Tilman 1982; Ellenberg 1988; Hyvönen \& Salonen 2002; Gerowitt 2003). For our study, we selected exclusively loamy soils. Therefore, the variability 
of local soil characteristics was low. However, in a pre-analysis (linear regressions), we tested if several soil and land-use characteristics were correlated with landscape complexity or weed species diversity. Therefore, one soil sample per field, consisting of 16 randomly taken sub samples from the top $30 \mathrm{~cm}$ was analysed. Data on land use were based on interviewing the farmers. Soil characteristics (total nitrogen contents, organic carbon contents, ratio of organic carbon to total nitrogen, $\mathrm{pH}$-value) in conventional as well as in organic fields were unrelated to percent arable land in the landscape $(R=-0.39$ to 0.18 ; all $P>0.2)$. Additionally, these soil characteristics were not related with any component of weed species diversity (i.e., alpha, beta, and gamma diversity, all $P$-values from linear regressions $>0.2$ ). The number of herbicide applications in conventional fields was one to three per year and also neither related to percent arable land $(R=-0.01 ; P=0.99)$ nor to weed species diversity (e.g., gamma diversity: $R=-0.01 ; P=0.98$ ). In contrast to expectations (Roschewitz, Thies $\&$ Tscharntke 2005), mineral nitrogen fertilizers $\left(\mathrm{kg} \mathrm{N} \mathrm{ha}^{-1}\right)$ applied in conventional fields even tended to decrease with increasing percent arable land $(R=-0.58 ; P=0.05)$, but they did not influence weed species diversity (e.g., gamma diversity: $R=0.43 ; P=0.17$ ).

\section{QUANTIFICATION OF ARABLE WEED SPECIES DIVERSITY}

\section{Vegetation}

The diversity and abundance of weeds were recorded three times during the growing season. The first sample date was in the beginning of April to record the initial state of the weeds in spring. This date was before herbicides were applied in the conventional fields (all conventional farmers used herbicides against broadleaves and grasses). The second sampling was conducted in the second half of May, the third in the middle of July. Sampling in all periods was conducted within one week. All broadleaf and grass species and their percentage cover were recorded in four $3 \mathrm{~m} \times 10 \mathrm{~m}$ plots per field using the nomenclature of plant names of Wisskirchen \& Haeupler (1998), and tree seedlings were not considered. Two plots were situated in the centre of the field (approx. 30m apart from any edge as well as $30 \mathrm{~m}$ from each other) and two plots at the field edge $(0 \mathrm{~m}-3 \mathrm{~m}$ apart from the first drill row and $30 \mathrm{~m}$ from each other). The locations of the vegetation plots were the same in all three samplings. Species numbers per plot were cumulated and percentage cover was averaged for the three sample dates.

\section{Germinable seed rain}

Germinable seed rain was measured from the beginning of April until the middle of July, which is the time where the seeds of most central European weeds are produced and dispersed (Kästner, Jäger \& Schubert 2001). To catch and hold the seeds, eight plastic boxes with a size of $50 \mathrm{~cm} x 32 \mathrm{~cm} x 6 \mathrm{~cm}$ filled with seedless garden soil were used. Four of the boxes were buried in the centre of the fields ( $30 \mathrm{~m}$ apart from the edge), the other four boxes at the field edge $(1 \mathrm{~m}-1.5 \mathrm{~m}$ apart from the first drill row). The boxes were arranged in pairs, with a 
distance of $50 \mathrm{~cm}$ to each other, the distance between the two pairs was $25 \mathrm{~m}$. The box pairs were placed close to and between the vegetation plots. The flower soil was watered regularly, depending on weather conditions. Once a month, all germinated plants were identified to species, counted and removed from the boxes. In the middle of July, before the wheat harvest, all boxes were removed from the fields and brought into the greenhouse, where all germinated plants were identified, counted and removed monthly for another 10 months. To initiate also the germination of frost germinators, we induced a three weeks frost period during the winter (by turning off the heating in strong frost period). Species numbers per box pair were cumulated for the 14 sample dates. This experiment was conducted in all fields, but one organic field was skipped due to destroyed boxes.

\section{Germinable seedbank}

To measure the germinable weed seedbank, we collected four samples of the soil of each winter wheat field at the beginning of September, after wheat harvest. Each sample consisted of eight sub-samples randomly taken from a plot of $20 \mathrm{~m}^{2}$. Two plots were located in the field centre and two at the edge, analogous to the seed rain experiment. The sub-samples were taken from the top $25 \mathrm{~cm}$ of the soil with the help of a spade. Most weeds are known to germinate and emerge from the first centimetres of the soil (Buhler 1995). However, $25 \mathrm{~cm}$ was chosen in order to get all seeds which potentially could germinate in the next years, as annual ploughing is normally conduced in this depth in our region (IR, unpublished data). The eight sub-samples were mixed and put into a plastic box (similar to the boxes in the seed rain experiment). The boxes were brought into the greenhouse, where all germinated plants were recorded monthly for 14 months. The samples were kept under the same conditions as the seed rain samples. Species numbers per box were cumulated for the 14 sample dates.

\section{ADDITIVE PARTITIONING OF WEED SPECIES DIVERSITY}

The total regional diversity can be seen as the sum of alpha diversity (mean diversity within the sampling units) and beta diversity (difference in diversity between the sampling units) (Allan 1975; Lande 1996). This relationship is not only valid for regional diversity but also for smaller scale diversity (Wagner et al. 2000). Thus, it is possible to additively partition species diversity in a region into scale-specific components. In our study, we partitioned species richness at two spatial scales, the regional and the field scale.

To describe the overall regional weed species diversity of the winter wheat fields (gamma diversity), we first calculated diversity of all species found on the regional scale (vegetation, seed rain, and seedbank pooled). The alpha diversity of the region was calculated as the mean number of species of all 24 wheat fields, as well as separately for 12 organic and 12 conventional fields. The gamma diversity of the region was calculated as the total species number of all 24 fields, and separately for 12 organic and 12 conventional fields. The beta diversity of the region (between-field diversity) was calculated by subtracting $\alpha$ from $\gamma$. 
In all three studies (vegetation, seed rain, and seedbank) the number of weed species was recorded for four plots per field, which allowed us to have a closer look at the within-field heterogeneity. The gamma diversity of a field $\left(\gamma_{\mathrm{f}}\right)$ was calculated as the total number of species per field. The alpha diversity $\left(\alpha_{\mathrm{f}}\right)$ was calculated as the mean number of species of the four plots per field. The beta diversity of a field $\left(\beta_{\mathrm{f}}\right.$, between-plot diversity) was generated by subtracting $\alpha_{\mathrm{f}}$ from $\gamma_{\mathrm{f}}$ and represents a measure of within-field heterogeneity. As species numbers were generally lower in conventional than in organic fields, we additionally calculated a relative beta diversity $(\beta \%=\beta / \gamma \times 100)$ on the regional as well as on the field level. This measure can be seen as the opposite of Lande's (1996) measure of community similarity, which was calculated as $\Psi_{D}=1-D_{\text {among }} / D_{\mathrm{T}}$ (in our terminology: $1-\beta / \gamma$ ).

\section{STATISTICAL ANALYSIS}

Mixed effect models (Pinheiro \& Bates 2000) with stepwise backward selection were used to analyse the effects of farming system, landscape complexity, and first order interaction on the alpha, beta, and gamma diversity of arable weeds at the field scale, and on the number of species registered in the Red List of threatened plant species of Lower Saxony (Germany) (Garve \& Letschert 1991; Garve 1993; Korneck et al. 1996). By blocking field pairs (organic/conventional), these models account for non-independent errors. Multiple logistic regressions (with stepwise backward selection) were used to examine which plant species were affected by landscape complexity and/or farming system. Therefore, the presence/absence of each species occurring in at least four fields (pooled for vegetation, seed rain, and seedbank) was related to the percentage of arable land and farming system. Statistical analyses were carried out using R (R Development Core Team 2004) and Statgraphics Plus 5.1 (Statistical Graphics Corp. 2001). Logarithmic transformation of the variables was used to achieve normality of the residuals, and arcsine-square-root transformation for the percentages (Sokal \& Rohlf 1995). In the text and tables, arithmetic means \pm standard deviations (SD) from original values are given. 


\section{Results}

\section{OVERVIEW}

In total, we found a gamma diversity in the region of 153 weed species, of which 135 were broadleaves and 18 grasses. In conventionally managed fields, 104 species were recorded (86 broadleaves and 18 grasses), in organically managed fields 142 species (126 broadleaves, 16 grasses) (Appendix). The average percentage of vegetation cover and numbers of seedlings germinated from the seed rain and seedbank are shown in Table 1. Eleven weed species were detected in conventional, but not in organic fields, and 49 species only in organic fields. Most of these species were only detected in one or two fields, indicating a high variability in local occurrence. 31 weed species were only found growing in crop fields, 10 species only in the seed rain, and 24 species only in the seedbank. 58 species appeared in the vegetation, the seed rain, and the seedbank. 23 species were registered in the Red List of threatened plant species of Lower Saxony (Germany), whereof 21 species were found in organic and 10 in conventional fields (Appendix).

Table 1. Percentage cover of weeds in the vegetation, numbers of seedlings $\mathrm{m}^{-2}$ ground in the seed rain, and numbers of seedlings $\mathrm{m}^{-2}$ ground in $0-25 \mathrm{~cm}$ depth in the seedbank. Medians, minima, and maxima are given for 12 organic and 12 conventional winter wheat fields (seed rain: 11 organic fields).

\begin{tabular}{|c|c|c|c|c|c|c|}
\hline & \multicolumn{2}{|c|}{ Median } & \multicolumn{2}{|c|}{ Minimum } & \multicolumn{2}{|c|}{ Maximum } \\
\hline & organic & conv. & organic & conv. & organic & conv. \\
\hline \multicolumn{7}{|c|}{ Vegetation (\% cover) } \\
\hline Broadleaves & 10.6 & 1.3 & 4.0 & 0.2 & 28.6 & 11.7 \\
\hline Grasses & 3.9 & 1.6 & 1.1 & 0.5 & 10.3 & 28.3 \\
\hline \multicolumn{7}{|c|}{ Seed rain (seedlings $\mathrm{m}^{-2}$ ) } \\
\hline Broadleaves & 2332 & 1779 & 1210 & 402 & 8996 & 3578 \\
\hline Grasses & 2300 & 1955 & 164 & 222 & 65148 & 36566 \\
\hline \multicolumn{7}{|c|}{ Seedbank (seedlings $\mathrm{m}^{-2}$ in $0-$} \\
\hline \multicolumn{7}{|c|}{$25 \mathrm{~cm})$} \\
\hline Broadleaves & 8093 & 2343 & 2015 & 968 & 23007 & 7414 \\
\hline Grasses & 2187 & 1371 & 242 & 445 & 9757 & 64046 \\
\hline
\end{tabular}


Alpha diversity at the regional scale (mean diversity per field) was 53.1 species (conventional fields: 43.7; organic fields: 62.6). Beta diversity (between-field diversity) was 99.9 species (conventional fields: 60.3 ; organic fields: 79.4 ). Hence, the relative beta diversity was $65.3 \%$ (conventional fields: 58.0; organic fields: 55.9\%). The species diversity and numbers of Red List species at the field scale are outlined in Table 2, separated for vegetation, seed rain, and seedbank. Diversity varied considerably between the two farming systems and the 12 landscapes.

Table 2. The alpha $\left(\alpha_{\mathrm{f}}\right)$, beta $\left(\beta_{\mathrm{f}}\right)$, relative beta $\left(\beta \%_{\mathrm{f}}\right)$, gamma $\left(\gamma_{\mathrm{f}}\right)$, and Red List species diversity of weeds at the field scale: data from vegetation, seed rain, and seedbank mappings. Means \pm SD, minima, and maxima are given for 12 organic and 12 conventional winter wheat fields (seed rain: 11 organic fields).

\begin{tabular}{|c|c|c|c|c|c|c|}
\hline & \multicolumn{2}{|c|}{ Mean \pm SD } & \multicolumn{2}{|c|}{ Minimum } & \multicolumn{2}{|c|}{ Maximum } \\
\hline & organic & conv. & organic & conv. & organic & conv. \\
\hline \multicolumn{7}{|l|}{ Vegetation } \\
\hline$\alpha_{f}$ & $29.7 \pm 7.4$ & $14.2 \pm 5.4$ & 19.8 & 6.8 & 43.0 & 21.3 \\
\hline$\beta_{f}$ & $18.1 \pm 4.0$ & $12.5 \pm 5.1$ & 10.3 & 5.3 & 23.0 & 20.5 \\
\hline$\beta \%_{f}(\%)$ & $38.0 \pm 5.4$ & $46.6 \pm 4.2$ & 29.0 & 40.3 & 47.9 & 52.5 \\
\hline$V_{f}$ & $47.8 \pm 10.2$ & $26.7 \pm 10.4$ & 30.0 & 13.0 & 66.0 & 40.0 \\
\hline Red List species & $1.4 \pm 1.8$ & $0.8 \pm 0.9$ & 0.0 & 0.0 & 6.0 & 2.0 \\
\hline \multicolumn{7}{|l|}{ Seed rain } \\
\hline$\alpha_{f}$ & $17.7 \pm 5.2$ & $10.2 \pm 3.6$ & 13.0 & 4.0 & 30.8 & 18.3 \\
\hline$\beta_{f}$ & $13.1 \pm 3.6$ & $10.3 \pm 2.3$ & 8.5 & 5.0 & 20.3 & 12.8 \\
\hline$\beta \%$ f $(\%)$ & $42.6 \pm 6.9$ & $51.0 \pm 6.3$ & 34.0 & 39.2 & 52.4 & 61.3 \\
\hline$Y_{f}$ & $30.8 \pm 7.6$ & $20.4 \pm 5.2$ & 23.0 & 9.0 & 51.0 & 30.0 \\
\hline Red List species & $1.0 \pm 1.2$ & $0.4 \pm 0.8$ & 0.0 & 0.0 & 3.0 & 2.0 \\
\hline \multicolumn{7}{|l|}{ Seedbank } \\
\hline$\alpha_{f}$ & $22.8 \pm 6.0$ & $14.6 \pm 3.7$ & 17.5 & 9.5 & 35.8 & 24.3 \\
\hline$\beta_{f}$ & $15.1 \pm 3.4$ & $13.1 \pm 2.9$ & 10.5 & 8.5 & 22.5 & 18.0 \\
\hline$\beta \%_{f}(\%)$ & $40.1 \pm 5.5$ & $47.3 \pm 6.9$ & 31.3 & 34.5 & 50.7 & 56.9 \\
\hline$Y_{f}$ & $31.8 \pm 8.2$ & $21.6 \pm 5.6$ & 23.0 & 14.0 & 46.0 & 31.0 \\
\hline Red List species & $1.9 \pm 2.1$ & $1.00 \pm 0.7$ & 0.0 & 0.0 & 6.0 & 2.0 \\
\hline
\end{tabular}




\section{RELATIVE INFLUENCE OF FARMING SYSTEM AND LANDSCAPE COMPLEXITY ON WEED SPECIES DIVERSITY}

In the vegetation, weed alpha, beta, and gamma diversity responded similarly to farming system and landscape complexity (= percent arable land). They were higher in organic than in conventional fields and decreased as percentage of arable land increased, i.e. they were higher in complex than in simple landscapes. This decrease was very steep in conventional, but not in organic fields, resulting in nearly similar diversities in the two farming systems in complex landscapes, and higher diversities in organic fields in simple landscapes (indicated by the interaction between percent arable land and farming system) (Fig. 1a-c, Table 3). In the seed rain, weed alpha, beta, and gamma diversity were higher in organic than in conventional fields and not related to percent arable land (Fig. 1d-f, Table 3). In the seedbank, weed alpha and gamma diversity were significantly higher in organic than in conventional fields. Additionally, they decreased with increasing percentage of arable land, irrespective of farming system (Fig. 1g, i, Table 3). For the beta diversity, no significant model could be found (Fig. 1h, Table 3). In all three studies, the relative within-field heterogeneity (beta \%) of weeds was significantly higher in conventional than in organic fields (vegetation: $F=27.0$; $P<0.001$; seed rain: $F=7.6 ; P<0.05$; seedbank: $F=8.9 ; P<0.05)$, and not related to landscape complexity.

When alpha, beta, gamma, and relative beta diversity were partitioned in broadleaf and grass diversity, it became clear that the above described patterns were mainly determined by the broadleaves (Table 3). Though alpha diversity of grasses in the vegetation increased with decreasing percent arable land and was higher in organic than in conventional fields, there was no significant interaction between percent arable land and farming system. Beta and gamma diversity of grasses in the vegetation also increased with decreasing percent arable land, but irrespective of farming system. Only the alpha and gamma diversity of grasses in the seed rain showed the same pattern as all weeds (higher in organic than in conventional fields). No significant models for the diversity of grasses could be found for beta diversity in the seed rain, relative beta diversity in all three studies, and all diversity components in the seedbank (for statistics, see Table 3). 
(a)

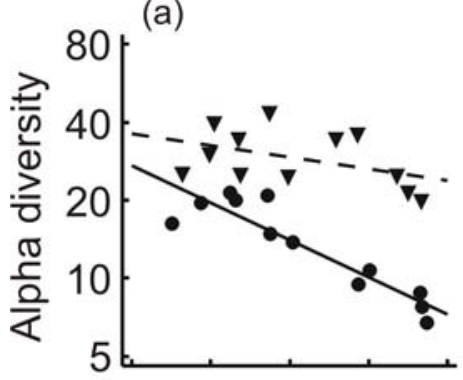

(d)

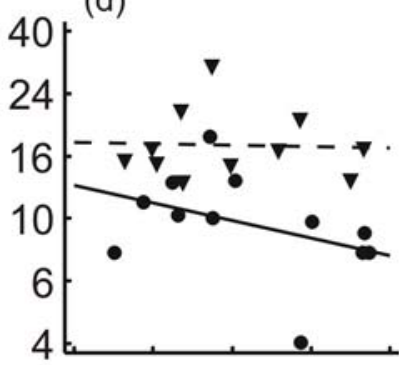

(e)

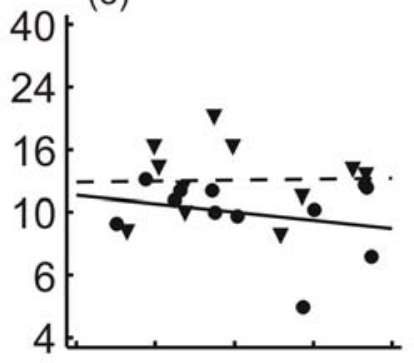

(g)

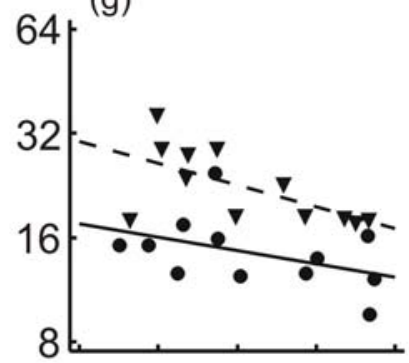

(b)

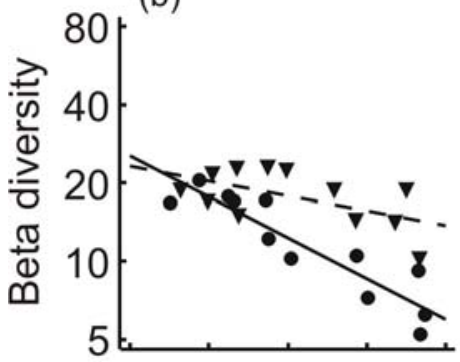

(c)

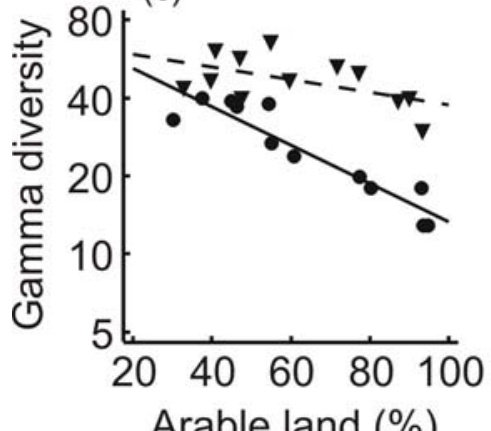

Arable land (\%)

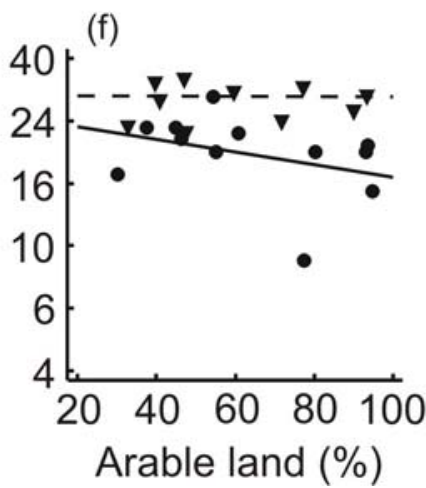

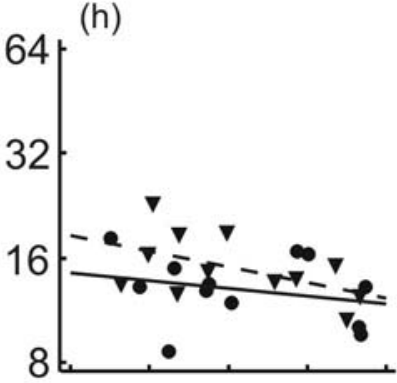

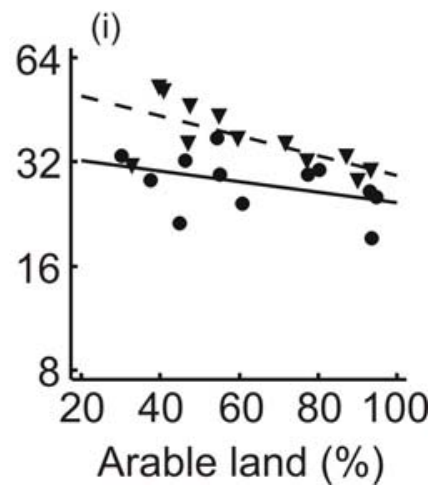

Figure 1. The field-scale alpha, beta, and gamma diversity of weeds in the vegetation (a, b, c), seed rain (d, e, f), and seedbank $(g, h, i)$ in dependence of percent arable land and farming system (organic vs. conventional). Results from mixed effect models (see Table 3). Organic fields = triangles and dashed regression lines; conventional fields $=$ points and solid regression lines. 
Table 3. The alpha $\left(\alpha_{\mathrm{f}}\right)$, beta $\left(\beta_{\mathrm{f}}\right)$, and gamma $\left(\gamma_{\mathrm{f}}\right)$ diversity of weeds (field scale) in the vegetation, seed rain, and seedbank in dependence of farming system and landscape complexity. $F$-values and levels of significance $(*: P$ $<0.05, * *: P<0.01, * * *: P<0.001)$ from mixed effect models, $\mathrm{n}=24$ wheat fields (seed rain: $\mathrm{n}=22$ fields).

\begin{tabular}{|c|c|c|c|}
\hline & Vegetation & Seed rain & Seedbank \\
\hline \multicolumn{4}{|l|}{ All weeds } \\
\hline \multicolumn{4}{|l|}{$\alpha_{f}$} \\
\hline A: Arable land (\%) & $35.0^{* * *}$ & n.s. & $9.0^{*}$ \\
\hline B: Farming system & $128.5^{\star * *}$ & $24.5^{* * *}$ & $31.4^{* * *}$ \\
\hline$A \times B$ & $13.5^{\star *}$ & n.s. & n.s. \\
\hline \multicolumn{4}{|l|}{$\beta_{f}$} \\
\hline A: Arable land (\%) & $39.3^{\star * \star}$ & n.s. & n.s. \\
\hline B: Farming system & $29.8^{* * *}$ & $5.2^{*}$ & n.s. \\
\hline$A \times B$ & $9.4^{*}$ & n.s. & n.s. \\
\hline \multicolumn{4}{|l|}{$\mathrm{Yf}_{f}$} \\
\hline A: Arable land (\%) & $46.6^{\star * *}$ & n.s. & $10.3^{* *}$ \\
\hline B: Farming system & $98.3^{* * *}$ & $19.3^{* *}$ & $18.4^{* *}$ \\
\hline$A \times B$ & $15.1^{\star *}$ & n.s. & n.s. \\
\hline \multicolumn{4}{|l|}{ Broadleaves } \\
\hline \multicolumn{4}{|l|}{$\alpha_{f}$} \\
\hline A: Arable land (\%) & $40.9^{* * *}$ & n.s. & $8.5^{\star}$ \\
\hline B: Farming system & $150.5^{* * *}$ & $19.9^{* *}$ & $34.8^{* * *}$ \\
\hline$A \times B$ & $18.5^{\star * \star}$ & n.s. & n.s. \\
\hline \multicolumn{4}{|l|}{$\beta_{f}$} \\
\hline A: Arable land (\%) & $34.3^{* * *}$ & n.s. & n.s. \\
\hline B: Farming system & $29.9^{* * *}$ & n.s. & n.s. \\
\hline$A \times B$ & $12.5^{\star \star}$ & n.s. & n.s. \\
\hline \multicolumn{4}{|l|}{$V_{f}$} \\
\hline A: Arable land (\%) & $45.5^{\star \star \star}$ & n.s. & $6.5^{\star}$ \\
\hline B: Farming system & $107.8^{* * *}$ & $18.6^{* *}$ & $16.3^{* *}$ \\
\hline$A \times B$ & $19.5^{\star \star}$ & n.s. & n.s. \\
\hline \multicolumn{4}{|l|}{ Grasses } \\
\hline \multicolumn{4}{|l|}{$a_{f}$} \\
\hline A: Arable land (\%) & $7.6^{*}$ & n.s. & n.s. \\
\hline B: Farming system & $8.3^{*}$ & $10.9^{* *}$ & n.s. \\
\hline$A \times B$ & n.s. & n.s. & n.s. \\
\hline \multicolumn{4}{|l|}{$\beta_{f}$} \\
\hline A: Arable land (\%) & $6.5^{*}$ & n.s. & n.s. \\
\hline B: Farming system & n.s. & n.s. & n.s. \\
\hline$A \times B$ & n.s. & n.s. & n.s. \\
\hline \multicolumn{4}{|l|}{$V_{f}$} \\
\hline A: Arable land (\%) & $10.6^{* *}$ & n.s. & n.s. \\
\hline B: Farming system & n.s. & $10.4^{* *}$ & n.s. \\
\hline$A \times B$ & n.s. & n.s. & n.s. \\
\hline
\end{tabular}




\section{SINGLE SPECIES}

Many species were either abundant in only very few or in nearly all fields. However, cumulated for vegetation, seed rain and seedbank, 64 out of 153 species were suitable for logistic regressions, i.e. they were present or absent in at least four fields (see Appendix). Only four of these species could be related to the percentage of arable land: Poa pratense L. occurred with $75 \%$ probability when percent arable land was lower than $34.7 \%(P<0.01$; percentage of deviance explained by the model (similar to $R^{2}$ ) $=39.2 \%$ ), Euphorbia helioscopia L. when arable land was lower than 33.2\% $(P<0.01 ; 26.0 \%)$, and Lamium amplexicaule L. when arable land was lower than $54.0 \%(P<0.05 ; 17.4 \%)$. Taraxacum officinale Weber occurred when arable land was lower than $83.7 \%$ in organic fields, and $66.6 \%$ in conventional fields ( $P_{\text {arable land }}<0.001 ; P_{\text {farming system }}<0.05 ; P_{\text {model }}<0.001 ; 84.4 \%$ ). Another eight species (Cerastium dubium (Bastard) Guépin, Equisetum arvensis L., Medicago sativa L., Potentilla reptans L., Trifolium pratense L., Tussilago farfara L., Vicia cracca L., Vicia faba L.) were significantly more present in organic farming, irrespective of landscape complexity ( $P$-values ranging from $<0.05$ to $<0.001$; percentages of deviance explained by the model ranging from 20.0 to $57.5 \%$ ). Independent of farming system, the number of Red List species per field in the vegetation decreased significantly when percent arable land increased (mixed effect models: $F=7.4 ; P<0.05$ ).

\section{Discussion}

In this study, local management (organic vs. conventional) and complexity of the surrounding landscape had an influence on alpha, beta, and gamma diversity of weeds in 24 winter wheat fields. The arable weed gamma diversity in the whole study region was 153 species. This overall diversity was greatly determined by the heterogeneity between the fields, as beta diversity made up $\sim 65 \%$. Similarly, Wagner et al. (2000) described low within-field diversity and large between-field diversity in arable fields and attributed this to crop variability. In our study, the crop species was the same in all analysed fields, which underlines the high variability of weed community structure in the region.

At the field scale, the gamma diversity of weeds in the vegetation was higher in organic than in conventional fields, a finding consistent with the results of other studies (Moreby et al. 1994; Hald 1999; Hyvönen et al. 2003). But our results showed that this was especially valid in fields located in simple landscapes with high percent arable land, as gamma diversity in conventional fields was strongly positively affected by landscape complexity, which resulted in nearly similar gamma diversities in organic and conventional fields when landscapes were complex with high percentages of non-crop areas. Gamma diversity of organic fields was only weakly related with landscape complexity, suggesting organic fields to be more or less selfsufficient ecosystems, not depending on species immigration from surrounding habitats in 
complex landscapes. Plant diversity of organic and conventional farms in Sweden showed a similar tendency: in conventional pastures and field margins, diversity tended to increase steeper with increasing perimeter-to-area ratio than in organic (Weibull et al. 2003), but this could not be proven statistically. Alpha and beta diversity revealed a similar pattern as gamma diversity.

In contrast to broadleaf diversity, the gamma and beta diversity of grasses in the vegetation did not differ between the farming systems, but were also negatively related with the percentage of arable land. The number of grass species was generally much lower than of broadleaves - in the whole study, only 18 grass species were found - which may partly explain why the observed differences between organic and conventional fields in broadleaf diversity could not generally be found in grasses. As all conventional farmers applied herbicides, broadleaf species may generally have been more affected by the applications than grasses, as suggested by Hole et al. (2005).

Reasons for the high importance of landscape complexity for the local weed species diversity, especially in conventional fields, might be found in the analysis of species entering the fields through the seed rain. Unexpectedly, species diversity in the seed rain appeared to be mainly determined by the local vegetation, as it was higher in organic than in conventional fields and not related to percent arable land. Many seeds appeared to come from the fields themselves, but not from the landscape. This is supported by several studies showing that seeds of many arable weeds were dispersed only a few meters from the mother plant (e.g., Rew, FroudWilliams \& Boatman 1996; Bischoff \& Mahn 2000). However, Fig. 1 shows a trend that in complex landscapes, diversity was high in both organic and conventional fields, whereas it decreased with increasing percentage of arable land only in conventional fields. This trend might not have been significant in the statistical models because of the high variability in the data, compared to the data of the vegetation analysis. But most of the weed species occurring in the seed rain, but not in the vegetation and seedbank (Appendix) should be relatively good dispersers because they are anemochor and/or zoochor (see Kästner et al. 2001). Their seeds should have had the potential to reach an arable field from the surrounding habitats which should provide a higher species pool in complex than in simple landscapes.

The gamma and alpha diversity in the seedbank were generally higher in organic than in conventional fields. The organic fields were at least for 7 years under organic management, which should be a time span long enough to fill the seedbank with species not occurring until the conversion to organic farming. Long-term effects of farming systems on weed species richness were also shown by Menalled et al. (2001). Additionally, weed species diversity decreased with increasing percentage of arable land, but in contrast to the diversity of the vegetation, the surrounding landscape affected both, organic and conventional fields similarly. So, landscape complexity did not seem to determine the weed species diversity of organic fields immediately (i.e. in the vegetation), but revealed the potential to do so in the following years, expressed via the more diverse germinable seedbank in complex landscapes. 
In contrast to the absolute beta diversities, the relative beta diversities of weeds in the vegetation, the seed rain, and the seedbank were higher in conventional than in organic fields, irrespective of landscape complexity. This shows the particular importance of the species heterogeneity within a field for the gamma diversity of conventional fields, as the mean (alpha) diversity within a field was comparatively low. Heterogeneity in conventional fields may be due to less intensive herbicide spraying and fertilisation at the field edges. Wilson and Aebischer (1995) showed that several weed species in conventional fields declined with increasing distance from the field edges, and Hald (1999) found a gradient in species density from edge to centre in conventional, but not in organic fields.

The number of Red List species in the vegetation was shown to be higher in complex than in simple landscapes, indicating a high importance of alternative habitats in the surrounding landscape for these species. However, numbers of species did not differ between organic and conventional fields. Thus, our study only partly supports the general opinion that the decline of particular species is caused by intensive agricultural practices at the field scale and the simplification of landscape complexity (e.g., Korneck \& Sukopp 1988; Jedicke 1997; Hofmeister \& Garve 1998). The unexpected similar numbers of Red List species in organic and conventional farming may result from a gradual decrease in the land-use intensity of conventional fields, which seemed to be irrespective of landscape complexity (see Methods). For example, the fertilizer consumption in Germany decreased from $\sim 3$ million $t$ (1991) to $\sim 2.6$ million $t$ (2001), and the herbicide consumption from $\sim 18000 t$ (1991) to $\sim 15000 t$ (2001) (FAO 2001). However, out of the 23 Red List species, 21 were found in organic fields, and only half of it (10 species) in conventional fields.

Results of multiple logistic regressions showed that only very few single species depended on landscape complexity and/or organic farming. Thus, higher species numbers found in complex landscapes and in organic farming cannot only be attributed to single species depending on such landscapes and/or organic farming. Which particular species have contributed to higher species numbers in complex landscapes is more likely to be a matter of chance. This might suggest mass effect (Shmida \& Wilson 1985; Auerbach \& Shmida 1987; Palmer 1992), which explains high local species richness with a continuously immigration from nearby but dissimilar habitats. One characteristic of many arable weed species is their ability to quickly colonise and survive in ruderal and disturbed habitats. Thus, the probability that many species randomly immigrate into a field is obviously greater when the proportion of alternative habitats in the landscape is increased. Eight species could be shown to depend on organic farming. These species were hemicryptophytes or geophytes and some of them legumes, which may have profited from diverse crop rotations including perennial crops for green manure. Legumes should be more competitive in organic than in conventional fields due to absent mineral nitrogen input.

Our results have implications for future management of both arable fields and landscape complexity to conserve species diversity of arable weeds, which are important components of 
the biodiversity in agricultural landscapes (Marshall et al. 2003). Organic farming generally promoted species diversity of arable weeds and the surrounding landscape was important for the seedbank. In conventional fields, species diversity strongly increased with increasing landscape complexity, thereby generating nearly similar diversity levels as in organic fields when the surrounding landscape was complex. Hence, organic farming contributed best to weed species diversity in simple agricultural landscapes. Therefore, the conversion of conventional to organic farming should be particularly effective and therefore especially supported in these areas. This is in contrast to present uptake of agri-environment schemes which is highest in areas where biodiversity is already relatively high and lowest where biodiversity is low (Kleijn \& Sutherland 2003), thereby not using species potential of agricultural landscapes to full capacity. Promoting non-crop habitats in agricultural landscapes as refuges for weed species appears to be of particular importance for landscape management, especially when organically managed fields are rare. Moreover, differences in species composition (beta diversity) have been shown to be very large within fields (particularly in conventional farming) and between fields thereby making an important contribution to overall diversity (gamma diversity) at the field and regional scale. Future management policies should therefore take into account the heterogeneity in community composition at different spatial scales.

\section{Acknowledgements}

We are grateful to the farmers who allowed us to work in their fields, Katja Poveda for statistical advice, Christof Bürger for GIS-support, and Jochen Krauss, Fabian Menalled, Thomas O. Crist and one anonymous referee for helpful comments on previous versions of the manuscript. This project was financially supported by the German Science Foundation (DFG) and the German Ministry for Research and Education (BMBF).

\section{References}

Allan, J.D. (1975) Components of diversity. Oecologia, 18, 359-367.

Auerbach, M. \& Shmida, A. (1987) Spatial scale and the determinants of plant species richness. Trends in Ecology and Evolution, 2, 238-242.

Bischoff, A. \& Mahn, E.-G. (2000) The effects of nitrogen and diaspore availability on the regeneration of weed communities following extensification. Agriculture, Ecosystems and Environment, 77, 237-246.

Buhler, D.D. (1995). Influence of tillage systems on weed population dynamics and management in corn and soybean in the central USA. Crop Science, 35, 1247-1258. 
Crist, T.O., Veech, J.A., Gering, J.C. \& Summerville, K.S. (2003) Partitioning species diversity across landscapes and regions: a hierarchical analysis of $\alpha, \beta$, and $\gamma$ diversity. American Naturalist, 162, 734-743.

Ellenberg, H. (1988) Vegetation Ecology of Central Europe, 4th edn. Cambridge University Press.

Food and Agriculture Organization of the United Nations (FAO) (2001) FAO Statistical Databases. http://apps.fao.org/.

Garve, E. (1993) Rote Liste der gefährdeten Farn- und Blütenpflanzen in Niedersachsen und Bremen. Informationsdienst Naturschutz Niedersachsen, 1/93, 47.

Garve, E. \& Letschert, D. (1991) Liste der wildwachsenden Farn- und Blütenpflanzen Niedersachsens. 1. Fassung vom 31.12.1990. Naturschutz und Landschaftspflege in Niedersachsen, 24, 154.

Gering, J.C. \& Crist, T.O. (2002) The alpha-beta-regional relationship: providing new insights into local-regional patterns of species richness and scale dependence of diversity components. Ecology Letters, 5, 433-444.

Gering, J.C., Crist, T.O. \& Veech, J.A. (2003) Additive partitioning of species diversity across multiple scales: implications for regional conservation of biodiversity. Conservation Biology, 17, 488-499.

Gerowitt, B. (2003) Development and control of weeds in arable farming systems. Agriculture, Ecosystems and Environment, 98, 247-254.

Grime, J.P. (1979) Plant strategies and vegetation processes, Wiley, Chichester.

Hald, A.B. (1999) Weed vegetation (wild flora) of long established organic versus conventional cereal fields in Denmark. Annals of Applied Biology, 134, 307-314.

Hofmeister, H. \& Garve, E. (1998) Lebensraum Acker, 2nd edn. Parey, Berlin.

Hole, D.G., Perkins, A.J., Wilson, J.D., Alexander, I.H., Grice, P.V. \& Evans, A.D. (2005) Does organic farming benefit biodiversity? Biological Conservation, 122, 113-130.

Holl, K.D. \& Crone, E.E. (2004) Applicability of landscape and island biogeography theory to restoration of riparian understorey plants. Journal of Applied Ecology, 41, 922-933.

Hutton, S.A. \& Giller, P.S. (2003) The effects of the intensification of agriculture on northern temperate dung beetle communities. Journal of Applied Ecology, 40, 994-1007.

Hyvönen, T. \& Salonen, J. (2002) Weed species diversity and community composition in cropping practices at two intensity levels - a six-year experiment. Plant Ecology, 154, 73-81.

Hyvönen, T., Ketoja, E., Salonen, J., Jalli, H. \& Tiainen, J. (2003) Weed species diversity and community composition in organic and conventional cropping of spring cereals. Agriculture, Ecosystems and Environment, 97, 131-149.

Jedicke, E. (Ed.) (1997) Die Roten Listen. Gefährdete Pflanzen, Tiere, Pflanzengesellschaften und Biotope in Bund und Ländern. E. Ulmer, Stuttgart. 
Kästner, A., Jäger, E. \& Schubert, R. (2001) Handbuch der Segetalpflanzen Mitteleuropas. Springer, Wien.

Kleijn, D., Berendse, F., Smit, R. \& Gilissen, N. (2001) Agri-environment schemes do not effectively protect biodiversity in Dutch agricultural landscapes. Nature, 413, 723-725.

Kleijn, D. \& Sutherland, W.J. (2003) How effective are European agri-environment schemes in conserving and promoting biodiversity? Journal of Applied Ecology, 40, 947-969.

Korneck, D. \& Sukopp, H. (1988) Rote Liste der in der Bundesrepublik Deutschland ausgestorbenen, verschollenen und gefährdeten Farn- und Blütenpflanzen und ihre Auswertung für den Arten- und Biotopschutz. Schriftenreihe für Vegetationskunde, 19, Bonn-Bad Godesberg.

Korneck, D., Schnittler, M. \& Vollmer, I. (1996) Rote Liste der Farn- und Blütenpflanzen (Pteridophyta et Spermatophyta) Deutschlands. Schriftenreihe für Vegetationskunde, 28, 21-187.

Krauss, J., Steffan-Dewenter, I. \& Tscharntke, T. (2003) How does landscape context contribute to effects of habitat fragmentation on diversity and population density of butterflies? Journal of Biogeography, 30, 889-900.

Krauss, J., Klein, A.M., Steffan-Dewenter, I. \& Tscharntke, T. (2004) Effects of habitat area, isolation, and landscape diversity on plant species richness of calcareous grasslands. Biodiversity and Conservation, 13, 1427-1439.

Krebs, J.R., Wilson, J.D., Bradbury, R.B. \& Siriwardena, G.M. (1999) The second silent spring? Nature, 400, 611-612.

Lande, R. (1996) Statistics and partitioning of species diversity, and similarity among multiple communities. Oikos, 76, 5-13.

Letourneau, D.K. \& Goldstein, B. (2001) Pest damage and arthropod community structure in organic vs. conventional tomato production in California. Journal of Applied Ecology, 38, 557-570.

Marshall, E.J.P., Brown, V.K., Boatman, N.D., Lutman, P.J.W., Squire, G.R. \& Ward, L.K. (2003) The role of weeds in supporting biological diversity within crop fields. Weed Research, 43, 77-89.

Menalled, F.D., Marino, P.C., Gage, S.H. \& Landis, D.A. (1999) Does agricultural landscape structure affect parasitism and parasitoid diversity? Ecological Applications, 9, 634641.

Menalled, F.D., Gross, K.L. \& Hammond, M. (2001) Weed aboveground and seedbank community responses to agricultural management systems. Ecological Applications, 11, 1586-1601.

Moreby, S.J., Aebischer, N.J., Southway, S.E. \& Sotherton, N.W. (1994) A comparison of the flora and arthropod fauna of organically and conventionally grown winter-wheat in southern England. Annals of Applied Biology, 125, 13-27. 
Palmer, M.W. (1992) The coexistence of species in fractal landscapes. The American Naturalist, 139, 375-397.

Pinheiro, J.C. \& Bates, D.M. (2000) Mixed effect models in S and S-plus, Springer-Verlag, New York.

R Development Core Team (2004) R: A language and environment for statistical computing, $\mathrm{R}$ Foundation for Statistical Computing, Vienna, Austria. URL http://www.Rproject.org.

Rew, L.J., Froud-Williams, R.J. \& Boatman, N.D. (1996) Dispersal of Bromus sterilis and Anthriscus sylvestris seed within arable field margins. Agriculture, Ecosystems and Environment, 59, 107-114.

Roschewitz, I., Thies, C. \& Tscharntke, T. (2005) Are landscape complexity and farm specialisation related to land-use intensity of annual crop fields? Agriculture, Ecosystems and Environment, 105, 87-99.

Schmidt, M.H., Roschewitz, I., Thies, C. \& Tscharntke T. (2005) The differential effects of landscape and management on diversity and density of ground-dwelling farmland spiders. Journal of Applied Ecology, in press.

Shmida, A. \& Wilson, M.V. (1985) Biological determinants of species diversity. Journal of Biogeography, 12, 1-21.

Sokal, R.R. \& Rohlf, F.J. (1995) Biometry, 3rd edn. Freeman \& Company, New York.

Statistical Graphics Corp. (2001) Statgraphics Plus Version 5.1.

Tilman, D. (1982) Resource competition and community structure. Princeton University Press, Princeton.

Tilman, D., Cassman, K.G., Matson, P.A., Naylor, R. \& Polasky, S. (2002) Agricultural sustainability and intensive production practices. Nature, 418, 671-677.

Wagner, H.H., Wildi, O. \& Ewald, K.C. (2000) Additive partitioning of plant species diversity in an agricultural mosaic landscape. Landscape Ecology, 15, 219-227.

Weibull, A.C., Östman, Ö. \& Granqvist, A. (2003) Species richness in agroecosystems: The effect of landscape, habitat and farm management. Biodiversity and Conservation, 12 , 1335-1355.

Wilson, P.J., Aebischer, N.J. (1995) The distribution of dicotyledonous arable weeds in relation to distance from the field edge. Journal of Applied Ecology, 32, 295-310.

Wisskirchen, R. \& Haeupler H. (1998) Standardliste der Farn- und Blütenpflanzen Deutschlands. Ulmer, Stuttgart. 
Appendix. Abundance (number of fields, in which each species occurred) and conservation status of weed species in the vegetation (V), seed rain (SR), and seedbank (SB) of 12 organic and 12 conventional winter wheat fields (seed rain: 11 organic fields).

\begin{tabular}{ccccccccc}
\hline \multicolumn{2}{c}{ Vegetation } & \multicolumn{2}{c}{ Seed rain } & \multicolumn{2}{c}{ Seedbank } & \multicolumn{2}{c}{$V+\mathrm{SR}+\mathrm{SB}$} \\
organic & conv. & organic & conv. & organic & conv. & organic & conv. \\
\hline
\end{tabular}

Broadleaves:

Achillea millefolium $\mathrm{L}$.

Aegopodium podagraria L.

Aethusa cynapium L.

Agrimonia eupatoria L.

Agrostemma githago L. ${ }^{1}$

Allium vineale $\mathrm{L}$.

Anagallis arvensis $\mathrm{L}$.

Androsace elongata L. ${ }^{5}$

Anthemis arvensis L. ${ }^{3}$

Anthriscus sylvestris (L.) Hoffm.

Aphanes arvensis $\mathrm{L}$.

Arabidopsis thaliana (L.) Heynh.

Artemisia vulgaris $\mathrm{L}$.

Atriplex patula L.

Brassica rapa L.

Capsella bursa-pastoris (L.) Med.

Carum carvi L. ${ }^{3}$

Centaurea cyanus L.

Cerastium arvense $\mathrm{L}$.

Cerastium dubium (Bastard) Guépin ${ }^{4}$

Cerastium glomeratum Thuill.

Cerastium holosteoides Fr.

Chaenorhinum minus (L.) Lange

Chenopodium album $\mathrm{L}$.

Chrysanthemum segetum $\mathrm{L}$.

Cirsium arvense (L.) Scop.

Cichorium intybus $\mathrm{L}$.

Consolida regalis ${ }^{3}$

Convolvulus arvensis L.

Crepis tectorum L. ${ }^{3}$

Daucus carota L.

Epilobium tetragonum $\mathrm{L}$.

Equisetum arvensis L.

Erophila verna (L.) DC.

Euphorbia exigua L.

Euphorbia helioscopia L.

Euphorbia platyphyllos L. ${ }^{2}$

Fallopia convolvulus (L.) Å. Löve

Filago arvensis L. ${ }^{2}$

Fumaria officinalis L.

Galeopsis segetum Neck. ${ }^{2}$

Galeopsis tetrahit L.

\begin{tabular}{|c|c|c|c|c|c|c|c|}
\hline 3 & 0 & 0 & 0 & 1 & 1 & 3 & 1 \\
\hline 1 & 0 & 0 & 0 & 0 & 0 & 1 & 0 \\
\hline 2 & 1 & 0 & 0 & 0 & 0 & 2 & 1 \\
\hline 1 & 0 & 0 & 0 & 0 & 0 & 1 & 0 \\
\hline 0 & 0 & 0 & 0 & 1 & 0 & 1 & 0 \\
\hline 1 & 1 & 0 & 0 & 0 & 0 & 1 & 1 \\
\hline 3 & 0 & 0 & 0 & 2 & 1 & 4 & 1 \\
\hline 0 & 0 & 3 & 2 & 3 & 0 & 5 & 2 \\
\hline 2 & 0 & 0 & 0 & 4 & 1 & 4 & 1 \\
\hline 4 & 3 & 0 & 0 & 0 & 0 & 4 & 3 \\
\hline 11 & 7 & 7 & 3 & 11 & 5 & 11 & 10 \\
\hline 6 & 2 & 7 & 2 & 6 & 1 & 10 & 4 \\
\hline 1 & 0 & 0 & 0 & 0 & 0 & 1 & 0 \\
\hline 1 & 0 & 1 & 0 & 0 & 0 & 2 & 0 \\
\hline 1 & 5 & 0 & 0 & 0 & 0 & 1 & 5 \\
\hline 10 & 4 & 4 & 2 & 11 & 12 & 12 & 12 \\
\hline 1 & 0 & 1 & 0 & 0 & 0 & 1 & 0 \\
\hline 3 & 1 & 0 & 0 & 5 & 0 & 5 & 1 \\
\hline 0 & 0 & 0 & 0 & 3 & 1 & 3 & 1 \\
\hline 2 & 0 & 2 & 0 & 2 & 0 & 4 & 0 \\
\hline 2 & 0 & 1 & 0 & 0 & 0 & 3 & 0 \\
\hline 4 & 1 & 0 & 0 & 0 & 0 & 4 & 1 \\
\hline 0 & 0 & 0 & 0 & 1 & 0 & 1 & 0 \\
\hline 3 & 1 & 2 & 1 & 10 & 8 & 10 & 9 \\
\hline 0 & 0 & 0 & 1 & 0 & 0 & 0 & 1 \\
\hline 12 & 10 & 7 & 6 & 8 & 3 & 12 & 11 \\
\hline 0 & 0 & 0 & 0 & 0 & 1 & 0 & 1 \\
\hline 0 & 0 & 0 & 0 & 1 & 0 & 1 & 0 \\
\hline 7 & 6 & 0 & 1 & 0 & 1 & 7 & 6 \\
\hline 2 & 1 & 2 & 2 & 0 & 0 & 4 & 3 \\
\hline 1 & 0 & 0 & 0 & 1 & 3 & 2 & 3 \\
\hline 8 & 3 & 11 & 12 & 12 & 11 & 12 & 12 \\
\hline 8 & 2 & 1 & 0 & 1 & 0 & 8 & 2 \\
\hline 1 & 0 & 1 & 1 & 2 & 0 & 2 & 1 \\
\hline 3 & 0 & 0 & 0 & 0 & 0 & 3 & 0 \\
\hline 5 & 3 & 0 & 0 & 1 & 0 & 5 & 3 \\
\hline 0 & 0 & 0 & 4 & 3 & 1 & 3 & 4 \\
\hline 12 & 7 & 6 & 3 & 11 & 8 & 12 & 10 \\
\hline 0 & 0 & 0 & 0 & 5 & 5 & 5 & 5 \\
\hline 5 & 2 & 1 & 0 & 2 & 1 & 6 & 3 \\
\hline 0 & 0 & 0 & 0 & 1 & 0 & 1 & 0 \\
\hline 8 & 4 & 3 & 0 & 2 & 2 & 8 & 4 \\
\hline
\end{tabular}




\begin{tabular}{|c|c|c|c|c|c|c|c|c|}
\hline & \multicolumn{2}{|c|}{ Vegetation } & \multicolumn{2}{|c|}{ Seed rain } & \multicolumn{2}{|c|}{ Seedbank } & \multicolumn{2}{|c|}{$V+S R+S B$} \\
\hline & organic & conv. & organic & conv. & organic & conv. & organic & conv. \\
\hline Galium aparine L. & 12 & 12 & 7 & 8 & 7 & 5 & 12 & 12 \\
\hline Galium mollugo L. ${ }^{5}$ & 0 & 1 & 0 & 0 & 0 & 0 & 0 & 1 \\
\hline Geranium dissectum L. & 3 & 2 & 0 & 0 & 2 & 3 & 3 & 4 \\
\hline Geranium pusillum Burm. f. & 4 & 3 & 1 & 1 & 1 & 1 & 4 & 3 \\
\hline Geranium rotundifolium L. & 0 & 0 & 1 & 0 & 0 & 0 & 1 & 0 \\
\hline Geum urbanum L. & 1 & 1 & 0 & 0 & 0 & 0 & 1 & 1 \\
\hline Glechoma hederacea L. & 2 & 0 & 0 & 0 & 0 & 0 & 2 & 0 \\
\hline Gnaphalium uliginosum L. & 0 & 0 & 0 & 0 & 1 & 0 & 1 & 0 \\
\hline Heracleum sphondylium L. & 4 & 3 & 0 & 1 & 0 & 0 & 4 & 4 \\
\hline Hieracium lachenalii C.C. Gmel. & 1 & 1 & 0 & 0 & 0 & 0 & 1 & 1 \\
\hline Holosteum umbellatum L. ${ }^{3}$ & 0 & 0 & 0 & 0 & 1 & 0 & 1 & 0 \\
\hline Hypericum perforatum L. & 1 & 0 & 0 & 0 & 2 & 2 & 3 & 2 \\
\hline Lamium amplexicaule L. & 9 & 5 & 2 & 1 & 2 & 2 & 9 & 6 \\
\hline Lamium purpureum L. & 10 & 10 & 10 & 6 & 9 & 11 & 11 & 12 \\
\hline Lapsana communis L. & 6 & 1 & 8 & 4 & 9 & 5 & 10 & 7 \\
\hline Lathyrus hirsutus L. & 0 & 0 & 0 & 0 & 1 & 0 & 1 & 0 \\
\hline Legousia speculum-veneris L. Chaix ${ }^{1}$ & 0 & 0 & 0 & 0 & 1 & 1 & 1 & 1 \\
\hline Leontodon hispidus L. & 0 & 0 & 1 & 1 & 0 & 1 & 1 & 1 \\
\hline Linaria vulgaris Mill. & 0 & 0 & 0 & 0 & 0 & 1 & 0 & 1 \\
\hline Matricaria perforata Mérat & 10 & 4 & 6 & 0 & 12 & 10 & 12 & 10 \\
\hline Matricaria recutita L. & 12 & 11 & 9 & 8 & 11 & 12 & 12 & 12 \\
\hline Medicago sativa L. & 5 & 0 & 3 & 0 & 1 & 0 & 6 & 0 \\
\hline Melampyrum arvense L. ${ }^{2}$ & 1 & 0 & 0 & 0 & 0 & 0 & 1 & 0 \\
\hline Mentha arvensis L. & 1 & 0 & 0 & 0 & 0 & 0 & 1 & 0 \\
\hline Myosotis arvensis (L.) Hill. & 11 & 9 & 11 & 10 & 11 & 10 & 12 & 12 \\
\hline Myosurus minimus L. ${ }^{3}$ & 0 & 1 & 1 & 0 & 2 & 3 & 2 & 3 \\
\hline Odontites vernus agg. & 0 & 0 & 1 & 2 & 0 & 0 & 1 & 2 \\
\hline Papaver dubium L. & 0 & 0 & 0 & 1 & 0 & 0 & 0 & 1 \\
\hline Papaver rhoeas L. & 9 & 5 & 9 & 4 & 9 & 8 & 11 & 9 \\
\hline Persicaria amphibia (L.) Delarbre & 0 & 0 & 0 & 0 & 1 & 1 & 1 & 1 \\
\hline Persicaria lapathifolia (L.) Delarbre & 1 & 0 & 5 & 5 & 8 & 3 & 12 & 6 \\
\hline Persicaria maculosa Gray & 3 & 1 & 4 & 5 & 1 & 1 & 5 & 6 \\
\hline Pimpinella major (L.) Huds. & 2 & 0 & 0 & 0 & 0 & 0 & 2 & 0 \\
\hline Plantago lanceolata L. & 1 & 0 & 0 & 0 & 0 & 0 & 1 & 0 \\
\hline Plantago major ssp. major & 1 & 0 & 0 & 1 & 2 & 0 & 2 & 1 \\
\hline Polygonum aviculare L. & 12 & 7 & 4 & 1 & 11 & 10 & 12 & 11 \\
\hline Potentilla anserina L. & 2 & 2 & 0 & 0 & 0 & 0 & 2 & 2 \\
\hline Potentilla reptans $\mathrm{L}$. & 5 & 0 & 0 & 0 & 0 & 0 & 5 & 0 \\
\hline Primula vulgaris Huds. ${ }^{1}$ & 0 & 1 & 0 & 0 & 0 & 0 & 0 & 1 \\
\hline Ranunculus arvensis L. ${ }^{2}$ & 2 & 0 & 1 & 0 & 0 & 0 & 3 & 0 \\
\hline Ranunculus repens L. & 10 & 3 & 1 & 1 & 3 & 2 & 11 & 4 \\
\hline Raphanus raphanistrum L. ${ }^{3}$ & 3 & 1 & 0 & 0 & 1 & 0 & 4 & 1 \\
\hline Rhinanthus alectorolophus (Scop.) & 0 & 0 & 1 & 0 & 0 & 0 & 1 & 0 \\
\hline \multicolumn{9}{|l|}{ Pollich ${ }^{1}$} \\
\hline Rubus caesius L. & 4 & 0 & 0 & 8 & 0 & 0 & 4 & 8 \\
\hline Rumex acetosella L. & 1 & 1 & 0 & 0 & 0 & 0 & 1 & 1 \\
\hline Rumex crispus L. L. & 11 & 2 & 6 & 4 & 11 & 8 & 12 & 10 \\
\hline
\end{tabular}




\begin{tabular}{|c|c|c|c|c|c|c|c|c|}
\hline & \multicolumn{2}{|c|}{ Vegetation } & \multicolumn{2}{|c|}{ Seed rain } & \multicolumn{2}{|c|}{ Seedbank } & \multicolumn{2}{|c|}{$V+S R+S B$} \\
\hline & organic & conv. & organic & conv. & organic & conv. & organic & conv. \\
\hline Rumex obtusifolius L. & 11 & 2 & 6 & 2 & 6 & 4 & 12 & 7 \\
\hline Scleranthus annuus L. & 1 & 0 & 1 & 0 & 2 & 0 & 3 & 0 \\
\hline Sedum telephium agg. & 0 & 0 & 0 & 0 & 1 & 0 & 1 & 0 \\
\hline Senecio vulgaris L. & 0 & 0 & 0 & 0 & 0 & 1 & 0 & 1 \\
\hline Sherardia arvensis L. ${ }^{3}$ & 1 & 0 & 0 & 0 & 1 & 0 & 1 & 0 \\
\hline Sinapis arvensis L. & 7 & 3 & 5 & 6 & 7 & 8 & 10 & 9 \\
\hline Sisymbrium officinale (L.) Scop. & 0 & 0 & 0 & 0 & 1 & 3 & 1 & 3 \\
\hline Solanum nigrum L. & 0 & 0 & 0 & 0 & 2 & 0 & 2 & 0 \\
\hline Sonchus arvensis L. & 8 & 1 & 5 & 6 & 9 & 6 & 11 & 10 \\
\hline Sonchus asper (L.) Hill & 0 & 0 & 3 & 0 & 3 & 2 & 4 & 2 \\
\hline Sonchus oleraceus L. & 0 & 0 & 0 & 0 & 1 & 0 & 1 & 0 \\
\hline Spergula arvensis L. & 0 & 0 & 0 & 0 & 2 & 0 & 2 & 0 \\
\hline Spergularia rubra (L.) J.\&C. Presl & 0 & 0 & 1 & 0 & 0 & 0 & 1 & 0 \\
\hline Stachys arvensis (L.) L. ${ }^{2}$ & 0 & 1 & 0 & 1 & 0 & 1 & 0 & 3 \\
\hline Stellaria aquatica (L.) Scop. & 0 & 0 & 0 & 0 & 1 & 0 & 1 & 0 \\
\hline Stellaria media (L.) Vill. & 12 & 9 & 10 & 9 & 11 & 10 & 12 & 11 \\
\hline Symphytum officinale L. & 0 & 1 & 0 & 0 & 0 & 1 & 0 & 1 \\
\hline Taraxacum officinale Weber & 10 & 6 & 6 & 2 & 0 & 2 & 10 & 7 \\
\hline Thlaspi arvense L. & 12 & 4 & 6 & 1 & 12 & 11 & 12 & 11 \\
\hline Trifolium arvense L. & 0 & 0 & 0 & 0 & 1 & 0 & 1 & 0 \\
\hline Trifolium hybridum L. & 1 & 0 & 0 & 0 & 2 & 0 & 3 & 0 \\
\hline Trifolium incarnatum L. & 1 & 0 & 0 & 1 & 1 & 0 & 2 & 1 \\
\hline Trifolium pratense L. & 8 & 0 & 0 & 0 & 2 & 0 & 9 & 0 \\
\hline Trifolium repens L. & 12 & 2 & 5 & 1 & 9 & 2 & 12 & 4 \\
\hline Trifolium resupinatum $\mathrm{L}$. & 1 & 0 & 0 & 0 & 0 & 0 & 1 & 0 \\
\hline Tussilago farfara L. & 6 & 0 & 0 & 0 & 1 & 0 & 7 & 0 \\
\hline Urtica dioica L. & 2 & 2 & 0 & 0 & 5 & 2 & 5 & 4 \\
\hline Urtica urens L. & 0 & 0 & 0 & 0 & 2 & 2 & 2 & 2 \\
\hline Valerianella locusta (L.) Laterr. & 1 & 0 & 0 & 0 & 0 & 0 & 1 & 0 \\
\hline Veronica arvensis L. & 7 & 5 & 5 & 2 & 9 & 5 & 10 & 7 \\
\hline Veronica chamaedrys L. & 1 & 0 & 0 & 0 & 0 & 0 & 1 & 0 \\
\hline Veronica hederifolia L. & 12 & 10 & 11 & 10 & 11 & 8 & 12 & 11 \\
\hline Veronica opaca $\mathrm{Fr}^{2}$ & 0 & 0 & 1 & 0 & 0 & 0 & 1 & 0 \\
\hline Veronica persica Poir. & 11 & 9 & 10 & 8 & 11 & 10 & 12 & 12 \\
\hline Veronica polita Fr. & 8 & 5 & 5 & 1 & 7 & 3 & 12 & 6 \\
\hline Veronica triphyllos L. ${ }^{3}$ & 0 & 0 & 1 & 0 & 0 & 0 & 1 & 0 \\
\hline Veronica verna L. ${ }^{2}$ & 0 & 0 & 1 & 0 & 0 & 0 & 1 & 0 \\
\hline Vicia articulata Hornem. & 1 & 0 & 0 & 0 & 0 & 0 & 1 & 0 \\
\hline Vicia cracca L. & 2 & 0 & 1 & 0 & 6 & 0 & 7 & 0 \\
\hline Vicia faba L. & 0 & 0 & 0 & 0 & 6 & 0 & 6 & 0 \\
\hline Vicia hirsuta (L.) Gray & 4 & 1 & 0 & 0 & 0 & 0 & 4 & 1 \\
\hline Vicea lutea L. & 0 & 0 & 0 & 0 & 1 & 0 & 1 & 0 \\
\hline Vicia sativa L. & 0 & 0 & 1 & 0 & 2 & 0 & 3 & 0 \\
\hline Vicia sepium L. & 2 & 0 & 0 & 0 & 0 & 0 & 2 & 0 \\
\hline Vicia tetrasperma (L.) Schreb. & 10 & 4 & 5 & 1 & 6 & 1 & 11 & 4 \\
\hline Vicia villosa subsp. villosa & 5 & 1 & 0 & 0 & 0 & 0 & 5 & 1 \\
\hline Viola arvensis Murray & 11 & 11 & 9 & 7 & 11 & 11 & 12 & 11 \\
\hline
\end{tabular}




\begin{tabular}{|c|c|c|c|c|c|c|c|c|}
\hline & \multicolumn{2}{|c|}{ Vegetation } & \multicolumn{2}{|c|}{ Seed rain } & \multicolumn{2}{|c|}{ Seedbank } & \multicolumn{2}{|c|}{$V+S R+S B$} \\
\hline & organic & conv. & organic & conv. & organic & conv. & organic & conv. \\
\hline \multicolumn{9}{|l|}{ Grasses: } \\
\hline Alopecurus myosuroides Huds. & 12 & 12 & 11 & 12 & 12 & 12 & 12 & 12 \\
\hline Alopecurus pratensis L. & 5 & 3 & 0 & 0 & 0 & 0 & 5 & 3 \\
\hline Apera spica-venti (L.) P. Beauv. & 11 & 12 & 9 & 5 & 12 & 11 & 12 & 12 \\
\hline $\begin{array}{l}\text { Arrhenatherum elatius (L.) P. Beauv. } \\
\text { ex J.\&C. Pesl }\end{array}$ & 7 & 4 & 1 & 1 & 0 & 1 & 7 & 6 \\
\hline Bromus arvensis L. ${ }^{2}$ & 3 & 4 & 0 & 2 & 0 & 0 & 3 & 4 \\
\hline Bromus hordeaceus L. & 0 & 0 & 0 & 1 & 0 & 0 & 0 & 1 \\
\hline Bromus sterilis L. & 3 & 4 & 2 & 2 & 0 & 1 & 4 & 5 \\
\hline Dactylis glomerata L. & 9 & 10 & 11 & 9 & 4 & 6 & 12 & 11 \\
\hline Elymus repens (L.) Gould & 12 & 12 & 10 & 6 & 11 & 8 & 12 & 12 \\
\hline Festuca rubra L. & 0 & 1 & 0 & 0 & 0 & 0 & 0 & 1 \\
\hline Holcus lanatus L. & 1 & 0 & 4 & 1 & 0 & 0 & 5 & 1 \\
\hline Juncus sphaerocarpus Nees ${ }^{5}$ & 4 & 0 & 5 & 5 & 7 & 7 & 10 & 9 \\
\hline Lolium multiflorum Lam. & 12 & 0 & 10 & 1 & 3 & 0 & 12 & 1 \\
\hline Lolium perenne L. & 6 & 8 & 3 & 7 & 2 & 4 & 9 & 11 \\
\hline Phleum pratense L. & 4 & 1 & 0 & 0 & 0 & 0 & 4 & 1 \\
\hline Poa annua $\mathrm{L}$. & 8 & 7 & 11 & 11 & 11 & 12 & 12 & 12 \\
\hline Poa pratensis L. & 3 & 2 & 1 & 0 & 0 & 0 & 4 & 2 \\
\hline Poa trivialis $\mathrm{L}$. & 12 & 12 & 11 & 12 & 11 & 12 & 12 & 12 \\
\hline
\end{tabular}

Note: Conservation status according to the Red List of threatened plant species of Lower Saxony (Germany) (Garve \& Letschert 1991; Garve 1993; Korneck et al. 1996):

${ }^{1}$ critically endangered

2 endangered

${ }^{3}$ vulnerable

${ }^{4}$ rare, potentially vulnerable

${ }^{5}$ regionally weaker vulnerable 


\section{Chapter 4}

\section{Landscape context of organic and conventional farms: influences on carabid beetle diversity}

Tobias Purtauf, Indra Roschewitz, Jens Dauber, Carsten Thies,

Teja Tscharntke \& Volkmar Wolters

Agriculture, Ecosystems and Environment, in press

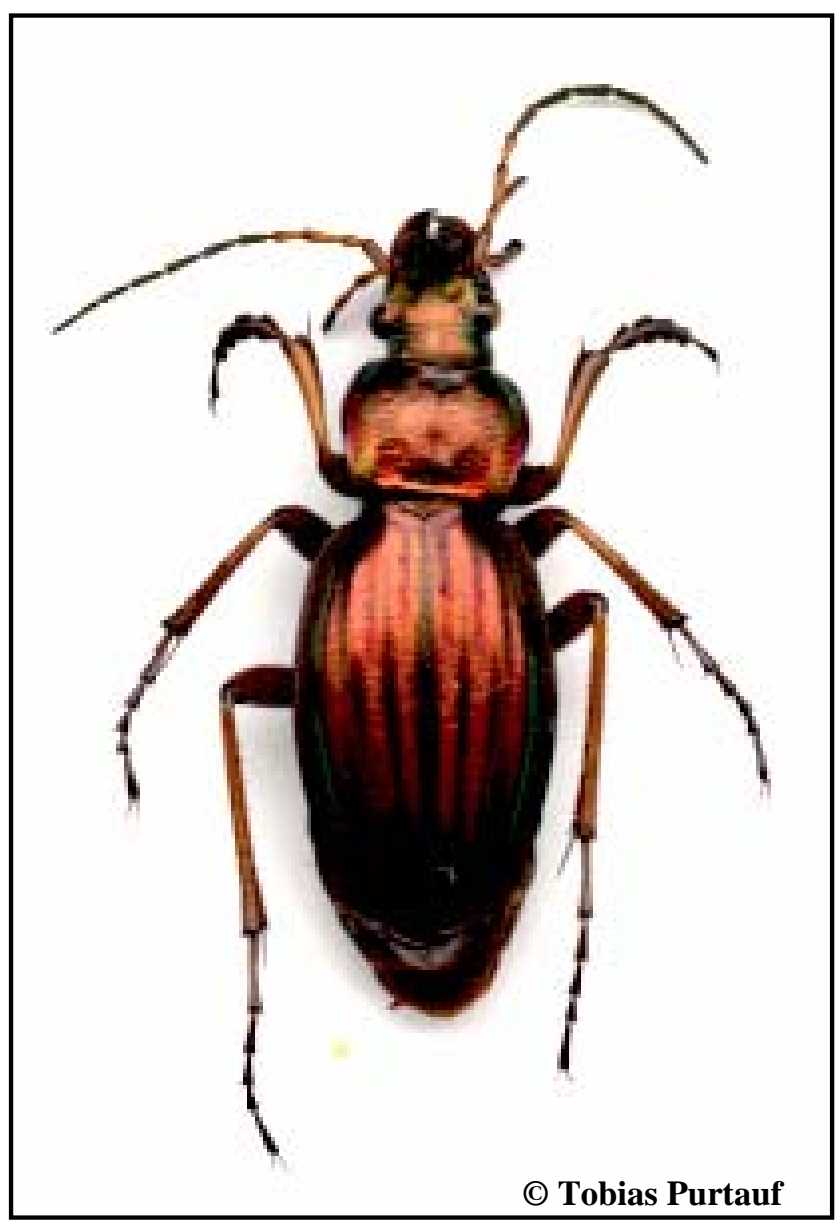




\begin{abstract}
Carabid species richness and density were studied in 12 pairs of organic versus conventional wheat fields located along a gradient of landscape complexity (quantified as percent cover of grassland, which was correlated with habitat-type diversity). The relative impact of local and landscape features was analyzed by comparing sites with similar landscape context but different management systems using pitfall traps. Organic and conventional management did not differ with respect to species richness and activity density. Seven species were more abundant under organic management, and eight species were more abundant under conventional management. The effect of landscape complexity was independent of management system. Species richness increased with percent cover of grassland in the surrounding landscape, and activity density followed the same trend. Hence, surrounding grassland appeared to act as a major source of diversity for farmland carabids. In particular, the activity density of spring breeders on organic fields benefited from the increased availability of overwintering habitats in their close surrounding. It was concluded that landscape features were much more important than organic farming management for enhancement of local biodiversity and should thus be considered in agri-environment schemes.
\end{abstract}

\title{
Key words
}

Carabidae; Biodiversity; Landscape context; Organic farming; Winter wheat 


\section{Introduction}

Many natural landscapes and habitats have been shaped by arable farming over centuries (Stanners and Bourdeau, 1995). Nearly 23\% of Europe is covered by arable land (European Communities, 2002). Among the many types of agricultural management, the European Union nowadays supports organic farming via agri-environmental schemes (Council Regulation, 1992, 1999). Organic farming in Europe has gone through major changes over the last 20 years. A break-through was achieved during the 1990s when it increased from nearly zero to around 2\% of the main part of European agriculture by 1999 (Michelsen, 2001). A national program of the German government aims to increase the share of organic land-use from the current level of 3.2-20\% over the next 10 years (BEL, 2003). Organic and low intensity farming systems are supposed to produce healthy food under conditions of more sustainable management practices (Reganold et al., 2001). Conventional farming with mineral fertilizers and chemical pesticides adversely affects soil arthropods directly through toxicity and indirectly by decreasing both food availability and habitat quality (Kromp, 1999; Holland and Luff, 2000). Organic farming, in contrast, may contribute to the protection of biodiversity (Dritschilo and Erwin, 1982; Paoletti, 1995; The Soil Association, 2000; Hyvönen et al., 2003).

Here, the impact of organic farming on carabid communities was investigated. The majority of studies on this issue focused on the response of individual species to management intensity at the field level (Kromp, 1989; Pfiffner and Niggli, 1996; Moreby et al., 1994; Andersen and Eltun, 2000; Mäder et al., 2002; Döring et al., 2003; Melnychuk et al., 2003; Pfiffner and Luka, 2003; Shah et al., 2003). This seems to be a much too narrow approach, because many factors that determine ecological patterns and processes take place at larger spatial scales such as landscapes and regions (Wiens et al., 1993; Ricklefs and Schluter, 1993; Thies and Tscharntke, 1999; Bestelmeyer et al., 2003). For example, landscape conditions have been proven to significantly affect population viability (Dunning et al., 1992; Burel et al., 2004). The study thus focused on species richness and activity density of carabids in 24 wheat fields (conventional farming versus organic farming) located in 12 agricultural landscapes differing in landscape composition in southern Lower Saxony (Germany). The relative impact of local and regional effects was quantified by comparing fields with similar landscape features but different farming management systems. It was expected that the quantity of the surrounding grasslands affects carabids by providing sites for reproduction and hibernation.

Studies investigating the relative importance of farming practices and landscape context are rare (De Blois et al., 2001; Weibull and Östman, 2003).Weibull et al. (2003) compared cereal farms managed either organically or conventionally and showed that the mode of farming had a small effect on the species richness of carabids relative to landscape effects. Therefore, the present study focused on: (i) the relative effect of management intensity on carabid species richness and activity density in winter-wheat fields, and on (ii) the modification of this effect 
by the surrounding landscape. Moreover, many carabid species hibernate in adjacent non-crop areas around the field and disperse in the fields during spring where they later reproduce (Coombes and Sotherton, 1986; Desender, 1982; Riedel, 1995; Andersen, 1997; Wallin, 1988; Kennedy, 1994; Holland et al., 1999; Petersen, 1999). The abundance of carabids on farmland is thus in part determined by the distribution and availability of suitable overwintering habitats (Sotherton, 1984). However, the multi-habitat use of carabids is different for different overwintering and hibernating strategies. Based on univoltine life cycles carabids have been classified as spring and autumn breeders, with the former group mainly hibernating as adults, and the latter group mainly hibernating as larvae (Thiele, 1977). Therefore, an additional question was (iii) whether the impact of landscape and management factors differs between carabids with different life cycles.

\section{Material and methods}

The study was conducted in 12 agricultural landscapes close to the city of Göttingen (Southern Lower Saxony, Central Germany). About $75 \%$ of the $1350 \mathrm{~km}^{2}$ area is covered by arable land/grassland mosaics. The remaining area is characterized by patchily distributed fragments of natural and semi-natural habitats such as forests, fallows, and hedgerows. Nearly $50 \%$ of the grassland sites in the study region are meadows (of which nearly two-thirds are extensively managed by mowing at most twice a year) and approx. one-third of the grassland sites are both intensively and extensively managed pastures (Finke, 2001). Twelve nonoverlapping landscape sectors of $1.5 \mathrm{~km}$ radius along a gradient from structurally simple, with $>80 \%$ arable land, to structurally complex, with $>50 \%$ non-crop habitats, were selected. The percent cover of grassland ranged from 5.4 to $25.9 \%$. Simple and complex landscapes were geographically interspersed. One conventionally and one organically managed (according to European Union Regulation 2092/91/EEC) winter-wheat field were chosen in the centre of each landscape sector to avoid differences in landscape context between the two management forms. There were no major differences between management techniques within each of the two farming forms. Preceding crops were mostly winter wheat and oilseed rape in conventional and a mixture of clover and grass in organic fields. Study sites on conventional farms were treated with mineral fertilizers $\left(183.09 \mathrm{~kg} \mathrm{~N} \mathrm{ha}^{-1} \pm 36.5\right)$, herbicides, fungicides and usually one insecticide spray in June (see Roschewitz et al. (2005) for details), whereas organic fields were fertilized with manure and weed was controlled mechanically. The mean field size was 3.3 ha. The percent cover of grassland [grassland (\%)] within a radius of $1.5 \mathrm{~km}$ around the study fields was used as a simple measure of landscape complexity. Grassland cover was positively correlated with habitat-type diversity (Shannon-Index; Spearman $R=$ $0.64, N=24, p<0.001)$. Landscape data was calculated from official digital thematic maps (ATKIS - Digitales Landschaftsmodell 25/1; Landesvermessung und Geobasisinformation, 
Hannover, Germany 1991-1996) using the Geographical Information System ArcView 3.3 (ESRI Geoinformatik GmbH, Hannover, Germany).

\section{Carabid data}

Carabids were sampled with pitfall traps consisting of $500 \mathrm{ml}$ polyethylene beakers (diameter $88 \mathrm{~mm}$ ) filled with approx. $0.12 \mathrm{~L}$ of a mixture (1:2) of ethylene glycol (antifreeze) and water. A detergent was added to reduce surface tension. Pieces of $2 \mathrm{~cm}$ mesh hardware cloth were inserted $3 \mathrm{~cm}$ beneath the opening to prevent vertebrates from entering. Acrylic glass roofs (250 $\mathrm{mm} \times 250 \mathrm{~mm}$ ) were positioned approximately $10 \mathrm{~cm}$ above each trap to prevent flooding by rain. Four pitfall traps were placed in a square of $10 \mathrm{~m} x 10 \mathrm{~m}$ with a minimum distance of $15 \mathrm{~m}$ from the field edge. Sampling took place in 2002 over the course of two 14day periods, starting on 8 May, and 28 June. During the study period from May to July 2002 the average temperature was $16.1{ }^{\circ} \mathrm{C}$ (long-term mean of average annual temperature is 8.7 ${ }^{\circ} \mathrm{C}$ ) and the rainfall was $282.9 \mathrm{~mm}$ (long-term mean of annual rainfall is $672 \mathrm{~mm}$; data from the meteorological station in Göttingen). All individuals were determined to species level (Freude, 1976) and sorted into functional groups according to their breeding type, i.e. spring and autumn breeders (Barndt et al., 1991; Lindroth, 1992; Ribera et al., 2001). Species for which no functional group classification was possible were excluded from the analysis. Site specific estimates of species richness and activity density of all carabids were gained by pooling the pitfall catches of each site.

\section{Data analysis}

Effects of management and landscape complexity on species richness and activity density were analyzed using general linear models (GLM). Management type (organic, conventional) was used as factor, and landscape complexity (grassland $\%=$ percent cover of grassland in the surrounding matrix) as the covariate. Additional GLMs were carried out to test the effects of management and landscape complexity on species richness and activity density of the different functional groups (spring breeders, autumn breeders). Homogeneity of variances was tested with Levene's test. Data were checked for normal distribution using Kolmogorov Smirnov test. At the species level, increased probabilities of falsely rejecting null hypotheses in multiple comparisons were avoided by considering Bonferroni corrections and by calculating the overall probability for the observed incidence of outcomes falling below the nominal significance level $p=0.05$ with Bernoulli equations (Moran, 2003). The effect of management on activity density was analyzed using paired t-tests. Statistical treatments were performed using SPSS for Windows package 11.0 (SPSS Inc., Illinois, USA) and Statistica for Windows Package 6.0 (StatSoft Inc., Tulsa, USA). In the text, arithmetic means \pm standard deviations (S.D.) are given. 


\section{Results}

In total, 11,562 carabids belonging to 66 species were trapped at the 24 study sites. Organic and conventional fields had the same species richness (55 species; see Appendix A for the density of all species in conventional and organic fields). The effect of management on both species richness and activity density was not significant (Table 1).

Species richness was positively related to the percent cover of grassland in the surrounding landscape independent of management type (Table 1, Fig. 1A). Although activity density tended to be higher in organic than in conventional fields, no significant effect of management could be established (Table 1). The effect of grassland (\%) on this parameter was only marginally significant (Table 1, Fig. 1B). Additionally, species richness of both spring and autumn breeders was positively related to grassland cover independent of management type (Table 1, Fig. 2). In contrast, only the activity density of spring breeders in organic fields was related to grassland (\%), as manifested by the management $x$ grassland (\%) interaction in the global test (Table 1, Fig. 3).

Table 1. General linear models on the effects of management (conventional vs. organic [M]) and the percent cover of grassland in the surrounding landscape $[\mathrm{G}(\%)]$ on carabid communities in winter-wheat fields (numerator degrees of freedom: 1, denominator degrees of freedom: 20).

\begin{tabular}{|c|c|c|c|c|c|c|}
\hline & \multicolumn{2}{|c|}{ M } & \multicolumn{2}{|c|}{ G (\%) } & \multicolumn{2}{|c|}{ M x G (\%) } \\
\hline & $\mathrm{F}$ & $p$ & $\mathrm{~F}$ & $p$ & $\mathrm{~F}$ & $p$ \\
\hline \multicolumn{7}{|l|}{ Species richness } \\
\hline Total species richness & - & - & 9.778 & 0.005 & - & - \\
\hline Spring breeders & - & - & 5.724 & 0.027 & - & - \\
\hline Autumn breeders & - & - & 8.235 & 0.009 & - & - \\
\hline \multicolumn{7}{|l|}{ Activity density } \\
\hline Total activity density & - & - & 3.481 & 0.077 & - & - \\
\hline Spring breeders & - & - & 5.930 & 0.024 & 5.0393 & 0.0362 \\
\hline Autumn breeders & - & - & - & - & - & - \\
\hline
\end{tabular}

The effect of management was significant at the species level. A sign test indicated that the majority of the 66 species did not display a trend towards higher activity density in response to one of the farming management types over the other $(Z=0.63, p=0.5)$. Matched pair tests for the 29 species occurring at six or more site pairs revealed that seven species had higher activity density under organic management, and eight species had higher activity density under conventional management $(a<0.05$, Table 2). This is significant according to the Bernoulli equation $(p<0.0001)$. 
Table 2. Significant results of the t-test for matched pairs for the 29 carabid species with six or more occurrences comparing conventional versus organic farming.

\begin{tabular}{lcc}
\hline & t-value & $\mathbf{p}$ \\
\hline Higher activity density in organic than in conventional farming & \\
Amara plebeja & -2.617 & 0.010 \\
Carabus auratus & -3.236 & 0.001 \\
Carabus granulatus & -3.012 & 0.003 \\
Agonum mülleri & -2.988 & 0.003 \\
Poecilus cupreus & -2.935 & 0.004 \\
Platynus dorsalis & -2.902 & 0.004 \\
Amara similata & -2.978 & 0.003 \\
Higher activity density in conventional than & in organic farming & \\
Loricera pilicornis & 3.366 & 0.001 \\
Clivina fossor & 3.075 & 0.002 \\
Nebria salina & 2.769 & 0.006 \\
Asaphidion flavipes & 2.759 & 0.006 \\
Notiophilus biguttatus & 2.381 & 0.018 \\
Amara eurynota & 2.326 & 0.021 \\
Pterostichus strenuus & 2.280 & 0.024 \\
Bembidion tetracolum & 2.180 & 0.030 \\
\hline
\end{tabular}
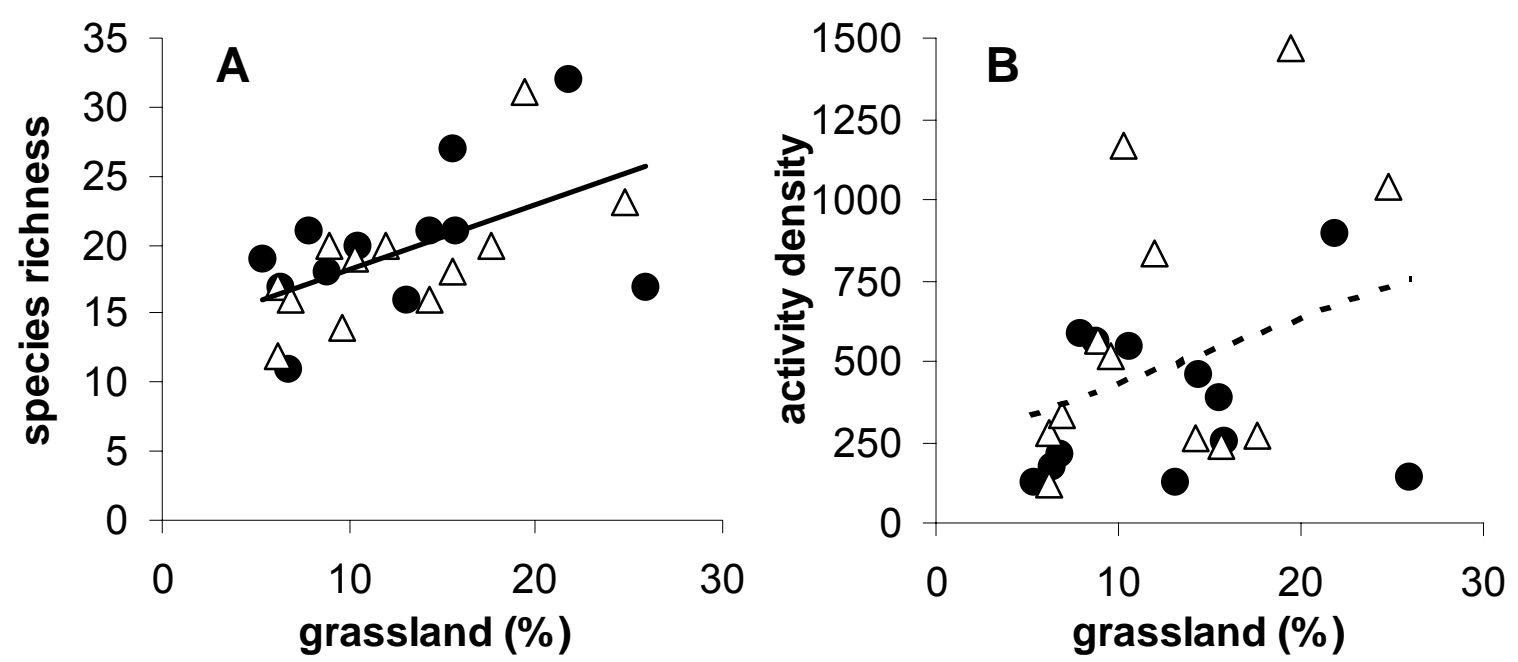

Figure 1. Correlation between the percent cover of grassland [grassland (\%)] and carabid community parameters on differently managed wheat fields (points = conventional fields; triangles = organic fields): (A) carabid species richness, and (B) activity density. (-) Significant main effect, (- - -) marginal significant effect. 

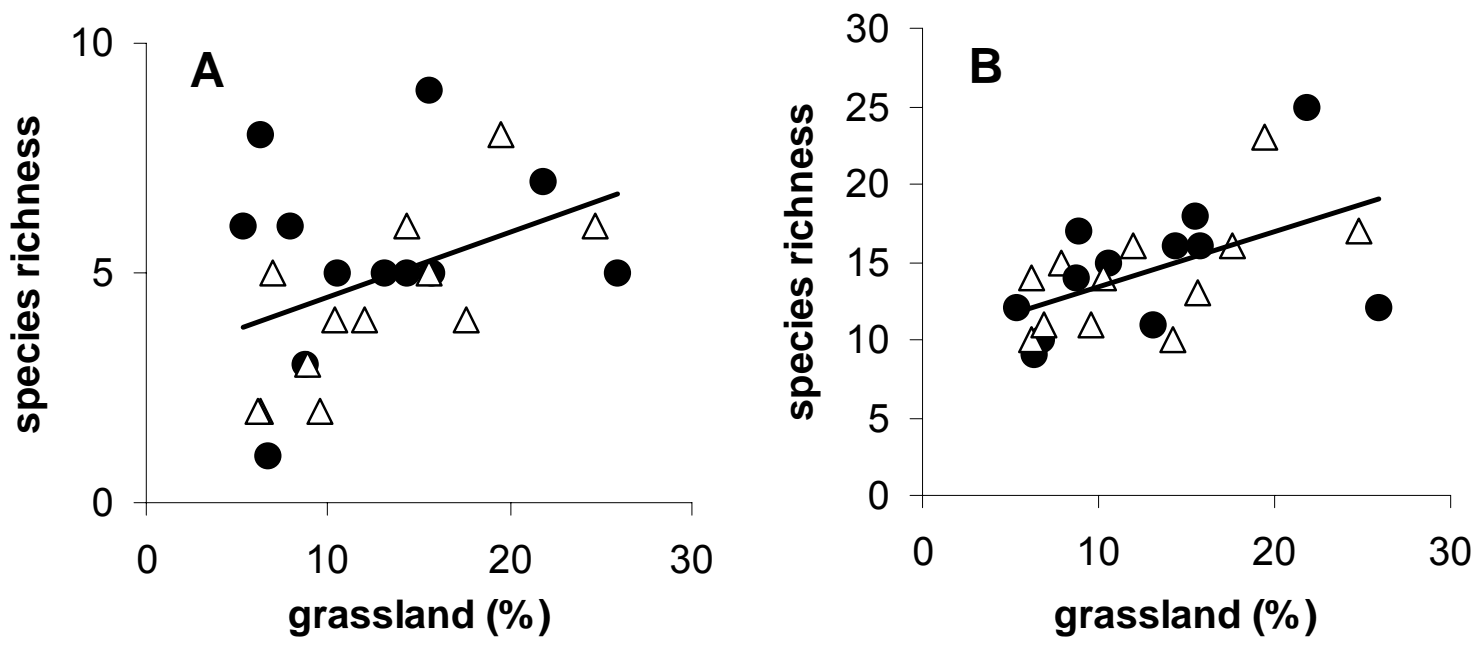

Figure 2. Correlation between the percent cover of grassland [grassland (\%)] and carabid functional groups on differently managed wheat fields points = conventional fields; triangles = organic fields): (A) autumn breeders, and (B) spring breeders. (-) Significant main effect.

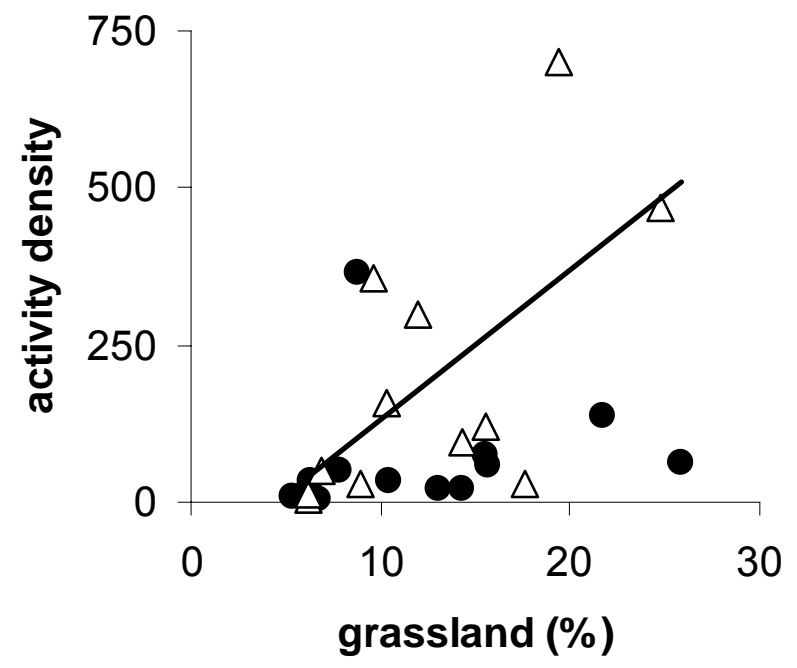

Figure 3. Correlation between the percent cover of grassland [grassland (\%)] and the activity density of spring breeders on differently managed wheat fields points $=$ conventional fields; triangles $=$ organic fields). ( $(-)$ Significant effect of the interaction management $x$ grassland (\%) for the organic fields.

\section{Discussion}

The relative importance of landscape context and local farming management (organic versus conventional) on carabid diversity in cereal fields was analyzed. In contrast to common expectations (e.g. Mäder et al., 2002), organic management did not enhance species richness. Moreover, landscape context (i.e., percent cover of surrounding grassland) had an effect on species richness irrespective of management type, whereas activity density showed only a 
marginally significant response. Andersen and Eltun (2000) also found no effect of organic farming on carabid species richness, whereas other authors report a slightly negative effect (Shah et al., 2003; Weibull et al., 2003), or even positive effects (Döring and Kromp, 2003; Irmler, 2003). It could not be fully excluded that effects of management may have been partly offset in the study by species exchange among sites due to the paired farms approach (Hadjicharalampous et al., 2002).

The results strongly support the conclusion of Weibull et al. (2003) that landscape structure is important for the species richness of carabids. The effect of surrounding grassland was statistically independent of the type of management, so there is convincing evidence that within a certain range - the diversity of arthropods in agroecosystems is affected much less by management practices than by landscape features (Schneider and Fry, 2001; Elliott et al., 2002; Boivin and Hance, 2003). The close link to the heterogeneity of surrounding habitats is explained by two factors. First, high habitat diversity in complex landscapes increases the species pools. Second, exchange of species that use multiple habitats during their life cycle can generate higher species richness in complex landscapes with a number of undisturbed semi-natural habitats (Zobel, 1997; Srivastava, 1999). This is very much true for carabids (Sotherton, 1984; Pfiffner and Luka, 2000). Hence, the results clearly demonstrate that surrounding grassland can act as a source of diversity for farmland carabids by offering refuges and corridors for beetles dispersing between and across fields.

The results found contrast with the higher activity density of carabids in organic systems reported by other authors (Mäder et al., 2002; Shah et al., 2003). Higher activity densities in organic fields may be caused by omitting pesticide applications, which negatively affect the carabid fauna in fields (Kromp, 1999). The findings could be partly due to the fact that no insecticides were used in the studied conventional fields prior to the first sampling period. Moreover, carabids benefit from the higher food sources from weed seeds and the higher abundance of carabid prey available from invertebrates associated with organic farming (Basedow, 1994; Hokkanen and Holopainen, 1986). At the species level, the results confirm the findings of Kromp and Steinberger (1992), Döring and Kromp (2003), and Irmler (2003) who described the same species to benefit from organic management due to microclimatic conditions and food supply. However, there was no evidence of a positive effect of better food availability in organic fields on total activity density, even though total coverage and species richness of arable weeds were higher (158 and 87\%, respectively; IR unpublished data).

Species richness of spring and autumn breeders was not affected by management, whereas it was positively related to the surrounding landscape for both groups. Nevertheless, group specific differences in the impact of landscape and management on activity density were found. Spring breeders particularly benefit from the surrounding landscape, because they usually hibernate as adults and migrate into the fields from surrounding overwintering sites and establish the 'early season' carabid community (Wallin, 1985; Coombes and Sotherton, 
1986). This confirms that the response of autumn breeders, in contrast, is much more variable. Some species leave the fields and move into adjacent uncultivated habitats in response to prey availability in late summer (Wallin, 1988; Fournier and Loreau, 2001). Others overwinter in the field as larvae (Noordhuis et al., 2001). Therefore, a universal effect of landscape complexity on the activity density of autumn breeders cannot be expected.

Significant interactions between landscape and management reflect that the increased activity density of spring breeders on organic fields was confined to landscapes with higher amounts of grassland. The interaction with management in complex landscapes can be explained by the condition of the carabids. Spring breeders in particular, such as Poecilus cupreus, are in better condition and have higher fecundity on organic farms situated in complex landscapes (Bommarco, 1998). This may cause higher activity densities on organic fields as the activity is related to the condition of the beetles (Fournier and Loreau, 2001), suggesting that positive landscape effects are related to carabid diet (e.g., aphids: Thies et al., 2003; weeds: Gabriel et al., 2002). This positive landscape effect might only be observed in organic fields, because intensive management on conventional fields may suppress it.

\section{Conclusion}

A high percentage of grassland habitats in agricultural landscapes enhanced carabids and their possible function as biocontrol agents in wheat fields. This landscape effect obscured the potential local effect of management intensity and thereby did not reveal an additional contribution of organic farming to the protection of biodiversity. Consequently, the restriction of agri-environmental schemes to landuse intensity and management type of agroecosystems does not take into account the much more important influence of the surrounding landscape for local diversity. On a landscape scale, converting arable land into perennial habitats should enrich local diversity. Further studies should consider the landscape context of ecological functions in addition to the role of different management systems. Such studies will reveal whether the findings are of general importance and apply to other landscape types. Given that the strength of predator impact on biocontrol depends on landscape features (Östman et al., 2001), the focus in maintaining biodiversity as well as ecosystem services in cultivated landscapes should expand to the landscape level.

\section{Acknowledgements}

We thank Manfred Hollenhorst for help with the statistics, Doreen Gabriel for help with GISanalyses, Sabine Mayr and Robin Nichoj for assistance in determining the carabids, and Nicole Maher for linguistic advice. This study was funded by the German Science Foundation (Deutsche Forschungsgemeinschaft) in the context of the "Sonderforschungsbereich 299" 
and the German Ministry of Education and Research (BMBF) in the context of the project "Biodiversity and Spatial Complexity in Agricultural Landscapes under Global Change" (BIOPLEX).

\section{References}

Andersen, A., 1997. Densities of overwintering carabids and staphylinids (Col., Carabidae and Staphylinidae) in cereal and grass fields and their boundaries. J. Appl. Entomol. 121, 77-80.

Andersen, A., Eltun, R., 2000. Long-term developments in the carabid and staphylinid (Col., Carabidae and Staphylinidae) fauna during conversion from conventional to biological farming. J. Appl. Entomol. 124, 51-56.

Barndt, D., Brase, S., Glauche, M., Gruttke, H., Kegel, B., Platen, R., Winkelmann, H., 1991. Die Laufkäferfauna von Berlin (West). In: Auhagen, A., Platen, R., Sukopp, H. (Eds.), Rote Listen der gefährdeten Pflanzen und Tiere in Berlin. Landschaftsentwicklung und Umweltforschung S 6, pp. 243-275.

Basedow, T., 1994. Phenology and egg production on Agonum dorsale and Pterostichus melanarius (Col., Carabidae) in winter wheat fields of different growing intensity in Northern Germany. In: Desender, K., Dufrêne, M., Loreau, M., Luff, M.L., Maelfait, J.P. (Eds.), Carabid Beetles: Ecology and Evolution. Kluwer Academic Publishers, Dordrecht, pp. 101-107.

Bestelmeyer, B.T., Miller, J.R., Wiens, J.A., 2003. Applying species diversity theory to land management. Ecol. Appl. 13, 1750-1761.

Boivin, G., Hance, T., 2003. Ground beetle assemblages in cultivated organic soil and adjacent habitats: temporal dynamics of microspatial changes. Pedobiologia 47, 193202.

Bommarco, R., 1998. Reproduction and energy reserves of a predatory carabid beetle relative to agroecosystem complexity. Ecol. Appl. 8, 846-853.

Bundesministerium für Verbraucherschutz, Ernährung und Landwirtschaft, 2003. Bundesprogramm Ökologischer Landbau. http://www.bundesprogrammoekolandbau.de.

Burel, F., Butet, A., Delettre, Y.R., Millàn de la Peña, N., 2004. Differential response of selected taxa to landscape context and agricultural intensification. Landscape Urban Plan. 67, 195-204.

Coombes, D.S., Sotherton, N.W., 1986. The dispersal and distribution of predatory Coleoptera in cereals. Ann. Appl. Biol. 108, 461-474.

Council Regulation, 1992. Council Regulation (EEC) 2078/1992 of June 30, 1992 on agricultural production methods compatible with the requirements of the protection of 
the environment and the maintenance of the countryside. Off. J. Eur. Communities L215, 85-90.

Council Regulation, 1999. Council Regulation (EC) 1257/1999 of May 17, 1999 on support for rural development from the European Agricultural Guidance and Guarantee Fund (EAGGF) and amending and repealing certain regulations. Off. J. Eur. Communities L160, 80-101.

De Blois, S., Domon, G., Bouchard, A., 2001. Environmental, historical and contextual determinants of vegetation cover: a landscape perspective. Landscape Ecol. 16, 421436.

Desender, K., 1982. Ecological and faunal studies on Coleoptera in agricultural land II. Hibernation of Carabidae in agro-ecosystems. Pedobiologia 23, 295-303.

Döring, T.F., Kromp, B., 2003. Which carabid species benefit from organic agriculture?-a review of comparative studies in winter cereals from Germany and Switzerland. Agric. Ecosyst. Environ. 98, 153-161.

Döring, T.F., Hiller, A., Wehkec, S., Schulte, G., Broll G., 2003. Biotic indicators of carabid species richness on organically and conventionally managed arable fields. Agric. Ecosyst. Environ. 98, 133-139.

Dritschilo, W., Erwin, T.L., 1982. Responses in abundance and diversity of cornfield carabid communities to differences in farm practices. Ecology 63, 900-904.

Dunning, J.B., Danielson, B.J., Pulliam, H.R., 1992. Ecological processes affect populations in complex landscapes. Oikos 65, 169-175.

Elliott, N.C., Kieckhefer, R.W., Beck, D.A., 2002. Effect of aphids and the surrounding landscape on the abundance of Coccinellidae in cornfields. Biol. Control 24, 214-220.

European Communities, 2002. Agriculture, Statistical yearbook, Data 1992-2001. Luxemburg.

Finke, K., 2001. Die Pflanzenartenvielfalt des Grünlands in unterschiedlich strukturierten Landschaften Südniedersachsens. Diploma-thesis, Göttingen Univ., Germany.

Fournier, E., Loreau, M., 2001. Activity and satiation state in Pterostichus melanarius: an experiment in different agricultural habitats. Ecol. Entomol. 26, 235-244.

Freude, H., 1976, Adephaga I: Familie Carabidae (Laufkäfer). In: Freude, H., Harde, K., Lohse, G.A. (Eds.), Die Käfer Mitteleuropas. Bd. 2, Fischer, Jena.

Gabriel, D., Thies, C., Tscharntke, T., 2002. Scale-dependent effects of landscape structure on plant diversity in cereal fields. Verhandlungen der Gesellschaft für Ökologie 32, 352.

Hadjicharalampous, E., Kalburtji, K.L., Mamolos, A.P., 2002. Soil Arthropods (Coleoptera, Isopoda) in Organic and Conventional Agroecosystems. Environmental Management $29,683-690$.

Hokkanen, H., Holopainen, J.K., 1986. Carabid species and activity densities in biologically and conventionally managed cabbage fields. J. Appl. Entomol. 102, 353-363. 
Holland, J.M., Luff, M.L., 2000. The effects of agricultural practices on Carabidae in temperate agroecosystems. Integrated Pest Management Reviews 5, 109-129.

Holland, J.M., Perry, J.N., Winder, L., 1999. The within-field spatial and temporal distribution of arthropods in winter wheat. B. Entomol. Res. 89, 499-513.

Hyvönen, T., Ketoja, E., Salonen, J., Jalli, H., Tiainen, J., 2003. Weed species diversity and community composition in organic and conventional cropping of spring cereals. Agric. Ecosyst. Environ. 97, 131-149.

Irmler, U., 2003. The spatial and temporal pattern of carabid beetles on arable fields in northern Germany (Schleswig-Holstein) and their value as ecological indicators. Agric. Ecosyst. Environ. 98, 141-151.

Kennedy, P.J., 1994. The distribution and movement of ground beetles in relation to set-aside arable land. In: Desender, K., Dufrêne, M., Loreau, M., Luff, M.L., Maelfait, J.-P. (Eds.), Carabid Beetles: Ecology and Evolution. Kluwer Academic Publishers, Dordrecht, pp. 439-444.

Kromp, B., 1989. Carabid beetle communities (Carabidae, Coleoptera) in biologically and conventionally farmed ecosystems. Agric. Ecosyst. Environ. 27, 241-251.

Kromp, B., 1999. Carabid beetles in sustainable agriculture: a review on pest control efficacy, cultivation impacts and enhancement. Agric. Ecosyst. Environ. 74, 187-228.

Kromp, B., Steinberger, K.-H., 1992. Grassy field margins and arthropod diversity: a case study on ground beetles and spiders in eastern Austria (Coleoptera: Carabidae; Arachnida: Aranei, Opiliones). Agric. Ecosyst. Environ. 40, 71-93.

Lindroth, C.H., 1992. Ground Beetles (Carabidae) of Fennoscandia. A zoogeographic study Part III, Smithsonian Institution Libraries and National Science Foundation, Washington, D.C.

Mäder, P., Fliessbach, A., Dubois, D., Gunst, L., Fried, P., Niggli, U., 2002. Soil fertility and biodiversity in organic farming. Science 296, 1694-1697.

Melnychuk, N.A., Olfert, O., Youngs, B., Gillott, C., 2003. Abundance and diversity of Carabidae (Coleoptera) in different farming systems. Agric. Ecosyst. Environ. 95, 6972.

Michelsen, J., 2001. Recent development and political acceptance of organic farming in Europe. Sociol. Ruralis 41, 3-20.

Moran, M.D., 2003. Arguments for rejecting the sequential Bonferroni in ecological studies. Oikos 100, 403-405.

Moreby, S.J., Aebischer, N.J., Southway, S.E., Sotherton, N.W., 1994. A comparison of the flora and arthropod fauna of organically and conventionally grown winter-wheat in southern England. Ann. Appl. Biol. 125, 13-27.

Noordhuis, R., Thomas, S.R., Goulson, D., 2001. Overwintering populations of beetles larvae (Coleoptera) in cereal fields and their contribution to adult populations in the spring. Pedobiologia 45, 84-95. 
Östman, Ö., Ekbom, B., Bengtsson, J., 2001. Landscape heterogeneity and farming practice influence biological control. Basic Appl. Ecol. 2, 365-371.

Paoletti, M.G., 1995. Biodiversity, traditional landscapes and agroecosystem management. Landscape Urban Plann. 31, 117-128.

Petersen, M.K., 1999. The timing of dispersal of the predatory beetles Bembidion lampros and Tachyporus hypnorum from hibernating sites into arable fields. Entomol. Exp. Appl. 90, 221-224.

Pfiffner, L., Luka, H., 2000. Overwintering of arthropods in soils of arable fields and adjacent semi-natural habitats. Agric. Ecosyst. Environ. 78, 215-222.

Pfiffner, L., Luka, H., 2003. Effects of low-input farming systems on carabids and epigeal spiders- a paired farm approach. Basic Appl. Ecol. 4, 117-127.

Pfiffner, L., Niggli, U., 1996. Effects of bio-dynamic, organic and conventional farming on ground beetles (Col. Carabidae) and other epigaeic arthropods in winter wheat. Biol. Agric. Hortic. 12, 353-364.

Reganold, P.R., Glover, J.D., Andrews, P.K., Hinman, H.R., 2001. Sustainability of three apple production systems. Nature 410, 926-929.

Ribera, I., Dolédec, S., Downie I.S., Foster, G.N., 2001. Effect of land disturbance and stress on species traits of ground beetle assemblages. Ecology 82, 1112-1129.

Ricklefs, R.E., Schluter, D., 1993. Species Diversity in Ecological Communities: Historical and Geographical Perspectives. Univ. Chicago Press, Chicago.

Riedel, W., 1995. Spatial distribution of hibernating polyphagous predators within field boundaries. Acta Jutlandica 70, 221-226

Roschewitz, I., Thies, C., Tscharntke, T., 2005. Are landscape complexity and farm specialisation related to land-use intensity of annual crop fields? Agric. Ecosyst. Environ., doi:10.1016/j.agee.2004.05.010.

Schneider, C., Fry. L.A., 2001. The influence of landscape grain on butterfly diversity in grasslands. Journal of Insect Conservation 5, 163-171.

Shah, P.A., Brooks, D.R., Ashby, J.E., Perry, J.N., Woiwod, I.P., 2003. Diversity and abundance of the coleopteran fauna from organic and conventional management systems in southern England. Agric. For. Entomol. 5, 51-60.

Sotherton, N.W., 1984. The distribution and abundance of predatory arthropods overwintering on farmland. Ann. Appl. Biol. 105, 423-429.

Srivastava, D.S., 1999. Using local-regional richness plots to test for species saturation: pitfalls and potentials. J. Anim. Ecol. 68, 1-16.

Stanners, D., Bourdeau, P. (Eds.), 1995. Europe's Environment: The Dobris Assessment. Office for Official Publications of the European Communities, Luxemburg.

The Soil Association, 2000. The biodiversity benefits of organic farming. www.soilassociation.org

Thiele, H.U., 1977. Carabid Beetles in Their Environments. Springer, New York. 
Thies, C., Steffan-Dewenter, I., Tscharntke, T., 2003. Effects of landscape context on herbivory and parasitism at different spatial scales. Oikos 101, 18-25.

Thies, C., Tscharntke, T., 1999. Landscape structure and biological control in agroecosystems. Science 285, 893-895.

Wallin, H., 1985. Spatial and temporal distribution of some abundant carabid beetles (Coleoptera: Carabidae) in cereal fields and adjacent habitats. Pedobiologia 28, 19-34.

Wallin, H., 1988. The effects of spatial distribution on the development and reproduction of Pterostichus cupreus L., P. melanarius Ill., P. niger Schal. and Harpalus rufipes deGeer (Col., Carabidae) on arable land. J. Appl. Entomol. 106, 483-487.

Weibull, A.C., Östman, Ö., 2003. Species composition in agroecosystems: The effect of landscape, habitat, and farm management. Basic Appl. Ecol. 4, 349-361.

Weibull, A.C., Östman, Ö., Granqvist, A., 2003. Species richness in agroecosystems: The effect of landscape, habitat and farm management. Biodivers. Conserv. 12, 1335-1355.

Wiens, J. A., Stenseth, N. C., Van Horne, B., Ims, R. A., 1993. Ecological mechanisms and landscape ecology. Oikos 66, 369-380.

Zobel, M., 1997. The relative role of species pools in determining plant species richness: an alternative explanation of species coexistence? Trends Ecol. Evol. 12, 266-269. 
Appendix. Mean activity density of carabids captured on 12 conventional and 12 organic fields (mean \pm SD). Classification of breeding type (BT) follows Barndt et al. (1991), Lindroth (1998), and Ribera et al. (2001).

\begin{tabular}{|c|c|c|c|}
\hline & $\mathrm{BT}^{\mathrm{a}}$ & conventional & organic \\
\hline Abax ovalis (DUFTSCHMID 1812) & SB & $0 \pm 0.2$ & $0 \pm 0.2$ \\
\hline Abax parallelepipedus (PILLER 1783) & $A B$ & $0.2 \pm 0.4$ & $0.3 \pm 0.8$ \\
\hline Acupalpus meridianus (LINNÉ 1767) & $A B$ & - & $0.2 \pm 0.8$ \\
\hline Agonum muelleri (HERBST 1784) & $A B$ & $1.5 \pm 2.8$ & $6.3 \pm 11.7$ \\
\hline Agonum sexpunctatum (LINNÉ 1758) & $A B$ & - & $0.3 \pm 0.7$ \\
\hline Amara aenea (DeGEER 1774) & $A B$ & $0 \pm 0.2$ & $0.1 \pm 0.3$ \\
\hline Amara aulica (PANZER 1797) & $A B$ & - & $0 \pm 0.2$ \\
\hline Amara communis (PANZER 1797) & $A B$ & $0 \pm 0.2$ & $0.1 \pm 0.3$ \\
\hline Amara eurynota (PANZER 1797) & SB & $1.2 \pm 3$ & $0.3 \pm 0.9$ \\
\hline Amara familiaris (DUFTSCHMID 1812) & $A B$ & $0.2 \pm 0.5$ & $0.2 \pm 0.5$ \\
\hline Amara lunicollis SCHIÖDTE 1837 & $A B$ & $0.1 \pm 0.3$ & $0 \pm 0.2$ \\
\hline Amara montivaga STURM 1825 & SB & - & $0.1 \pm 0.4$ \\
\hline Amara ovata (FABRICIUS 1792) & SB & $0.2 \pm 1$ & $0.4 \pm 1.7$ \\
\hline Amara plebeja (GYLLENHAL 1810) & SB & $1.5 \pm 3.8$ & $9.2 \pm 25.6$ \\
\hline Amara similata (GYLLENHAL 1810) & $A B$ & $0.4 \pm 1.1$ & $8.7 \pm 26.4$ \\
\hline Anisodactylus binotatus (FABRICIUS 1787) & $A B$ & $0 \pm 0.2$ & $0.1 \pm 0.3$ \\
\hline Asaphidion flavipes (LINNÉ 1761) & SB & $2 \pm 4.6$ & $0.3 \pm 0.8$ \\
\hline Badister bipustulatus FABRICIUS 1792 & SB & - & $0.1 \pm 0.3$ \\
\hline Bembidion guttula (FABRICIUS 1792) & SB & - & $0 \pm 0.2$ \\
\hline Bembidion lampros (HERBST 1784) & $A B$ & $1.6 \pm 3$ & $0.8 \pm 1.6$ \\
\hline Bembidion lunulatum (FOURCROY 1785) & SB & $0.3 \pm 1.4$ & - \\
\hline Bembidion obtusum SERVILLE 1821 & $A B$ & $0.7 \pm 2.5$ & $0 \pm 0.2$ \\
\hline Bembidion tetracolum SAY 1823 & SB & $1.7 \pm 3.5$ & $0.5 \pm 1.5$ \\
\hline Calathus fuscipes (GOEZE 1777) & $A B$ & $0.3 \pm 0.9$ & $0.7 \pm 2.5$ \\
\hline Calathus melanocephalus (LINNÉ 1761) & $A B$ & $0 \pm 0.2$ & $0 \pm 0.2$ \\
\hline Carabus auratus LINNÉ 1759 & $A B$ & $3 \pm 6.8$ & $35.6 \pm 97.2$ \\
\hline Carabus auronitens FABRICIUS 1792 & $A B$ & - & $0 \pm 0.2$ \\
\hline Carabus cancellatus ILLIGER 1798 & SB & $0 \pm 0.2$ & $4.8 \pm 16.3$ \\
\hline Carabus convexus FABRICIUS 1775 & SB & $0.1 \pm 0.4$ & $0.3 \pm 1.2$ \\
\hline Carabus coriaceus LINNÉ 1758 & $A B$ & $0.1 \pm 0.4$ & - \\
\hline Carabus granulatus LINNÉ 1758 & $A B$ & $6.5 \pm 6.7$ & $11.8 \pm 11.1$ \\
\hline Carabus nemoralis MÜLLER 1794 & $A B$ & $1.8 \pm 2$ & $2.8 \pm 4.8$ \\
\hline Clivina fossor (LINNÉ 1758) & SB & $1.6 \pm 4.1$ & - \\
\hline Demetrias atricapillus (LINNÉ 1758) & $?$ & $0.1 \pm 0.3$ & $0 \pm 0.2$ \\
\hline Harpalus affinis (SCHRANK 1781) & $A B$ & $0 \pm 0.2$ & - \\
\hline Harpalus dimidiatus (ROSSI 1790) & SB & $3.7 \pm 7.3$ & $4 \pm 5.7$ \\
\hline
\end{tabular}




\begin{tabular}{|c|c|c|c|}
\hline & $\mathrm{BT}^{\mathrm{a}}$ & conventional & organic \\
\hline Harpalus latus (LINNÉ 1758) & $\mathrm{AB}$ & - & $0.1 \pm 0.3$ \\
\hline Harpalus rubripes (DeGEER 1774) & $A B$ & $0.2 \pm 0.4$ & $0.1 \pm 0.3$ \\
\hline Harpalus rufitarsis DUFTSCHMID 1812 & $A B$ & $0 \pm 0.2$ & - \\
\hline Harpalus tardus (PANZER 1797) & SB & $0 \pm 0.2$ & - \\
\hline Loricera pilicornis (FABRICIUS 1775) & $A B$ & $7.2 \pm 13.7$ & $1.9 \pm 1.7$ \\
\hline Molops elatus (FABRICIUS 1801) & $?$ & $0.2 \pm 0.8$ & - \\
\hline Nebria brevicollis (FABRICIUS 1792) & $A B$ & $1.4 \pm 6.1$ & $3.6 \pm 8.4$ \\
\hline Nebria salina FAIRMAIRE 1854 & $A B$ & $6.4 \pm 10.8$ & $2.2 \pm 5.3$ \\
\hline Nothiophilus aquaticus (LINNÉ 1758) & SB & $0.1 \pm 0.4$ & $0 \pm 0.2$ \\
\hline Nothiophilus biguttatus (FABRICIUS 1779) & SB & $0.6 \pm 1.4$ & $0.1 \pm 0.6$ \\
\hline Nothiophilus palustris (DUFTSCHMID 1812) & SB & $0.2 \pm 0.4$ & $0 \pm 0.2$ \\
\hline Panagaeus bipustulatus (FABRICIUS 1775) & $A B$ & $0 \pm 0.2$ & $0.1 \pm 0.3$ \\
\hline Panagaeus cruxmajor (LINNÉ 1758) & $A B$ & $0 \pm 0.2$ & - \\
\hline Platynus assimilis (PAYKULL 1790) & SB & $0.5 \pm 0.9$ & $0.9 \pm 2.5$ \\
\hline Platynus dorsalis (PONTOPPIAN 1763) & $A B$ & $25.6 \pm 29.9$ & $44.4 \pm 48.8$ \\
\hline Poecilus cupreus (LINNÉ 1758) & SB & $26 \pm 71.1$ & $79.4 \pm 145.6$ \\
\hline Poecilus versicolor (STURM 1824) & $A B$ & $4 \pm 11.2$ & $8.9 \pm 32.9$ \\
\hline Pseudophonus rufipes (DeGEER 1774) & $A B$ & $5.8 \pm 10.8$ & $7.6 \pm 15.5$ \\
\hline Pterostichus burmeisteri HEER 1841 & $A B$ & $0.2 \pm 0.4$ & $0.1 \pm 0.3$ \\
\hline Pterostichus madidus (FABRICIUS 1775) & $?$ & - & $0.1 \pm 0.4$ \\
\hline Pterostichus melanarius (ILLIGER 1798) & $A B$ & $73.8 \pm 103.8$ & $56.3 \pm 59.3$ \\
\hline Pterostichus niger (SCHALLER 1783) & $A B$ & $3.4 \pm 12.7$ & $0.6 \pm 1.2$ \\
\hline Pterostichus oblongopunctatus (FABRICIUS 1787) & SB & $0 \pm 0.2$ & - \\
\hline Pterostichus ovoideus (STURM 1824) & $?$ & - & $0 \pm 0.2$ \\
\hline Pterostichus strenuus (PANZER 1797) & $A B$ & $1.2 \pm 4.1$ & $0 \pm 0.2$ \\
\hline Pterostichus vernalis (PANZER 1796) & $A B$ & $0.5 \pm 1.1$ & $0.5 \pm 0.8$ \\
\hline Stomis pumicatus (PANZER 1796) & SB & - & $0 \pm 0.2$ \\
\hline Synuchus vivalis (ILLIGER 1798) & $A B$ & $0 \pm 0.2$ & - \\
\hline Trechus obtusus ERICHSON 1837 & $A B$ & $0.2 \pm 0.8$ & $0.3 \pm 0.7$ \\
\hline Trechus quadristriatus (SCHRANK 1781) & $A B$ & $0 \pm 0.2$ & - \\
\hline
\end{tabular}

${ }^{\text {a }} \mathrm{SB}=$ spring breeder, $\mathrm{AB}=$ autumn breeder, ? = no classification possible. 


\section{Chapter 5}

\section{The differential effects of landscape and management on diversity and density of ground-dwelling farmland spiders}

Martin H. Schmidt, Indra Roschewitz, Carsten Thies \& Teja Tscharntke Journal of Applied Ecology, in press

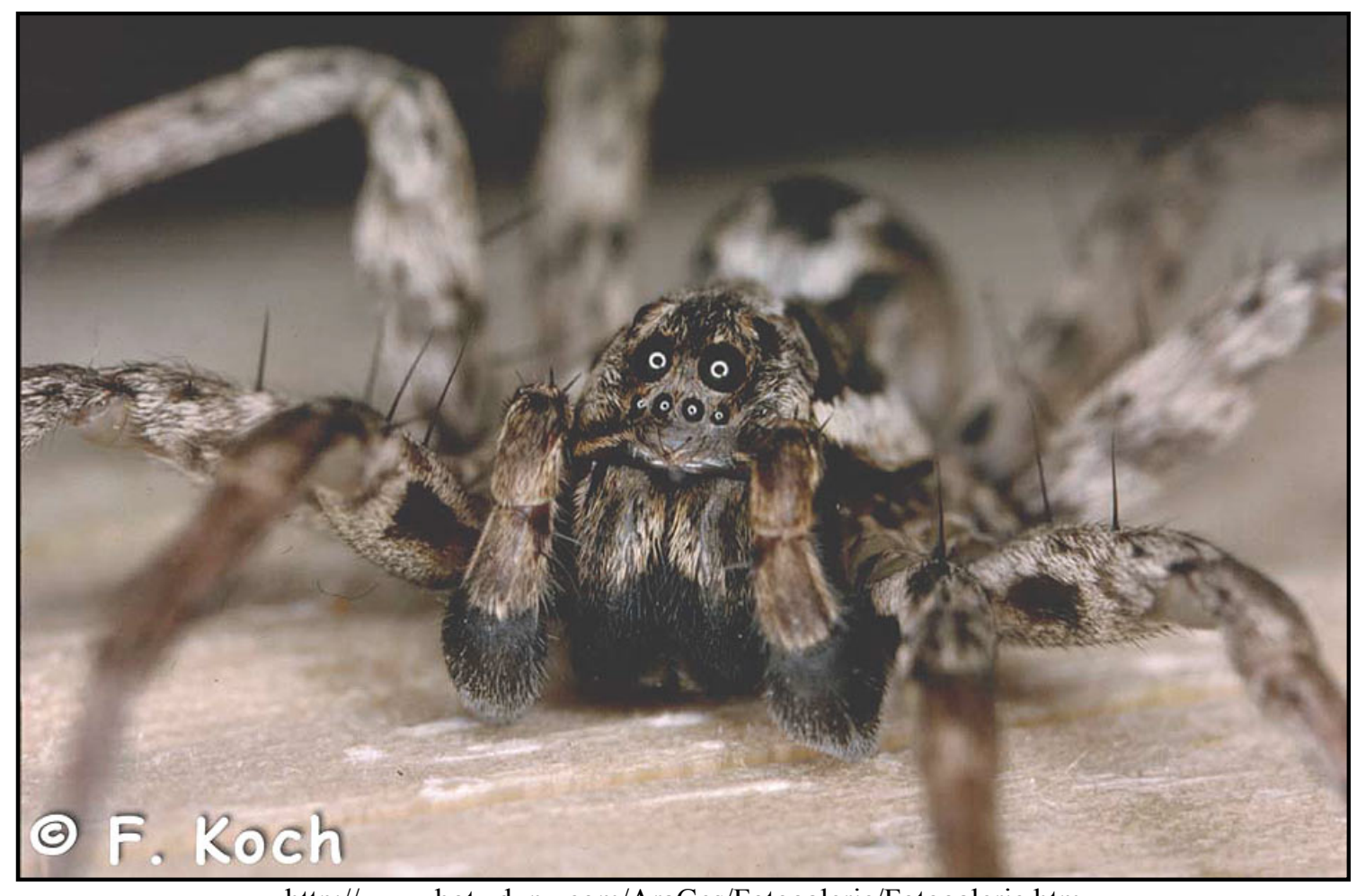

http://www.botz.dynu.com/AraGes/Fotogalerie/Fotogalerie.htm 


\begin{abstract}
1. The distribution and abundance of animals is influenced by factors at both local and wider landscape scales. Natural enemies of pests in arable fields often immigrate from the surrounding landscape, and are additionally influenced by local management practices. Thus, landscape diversification and organic farming may both enhance farmland biodiversity, but their relative role and possible interactions have been little explored.

2. Here, the relationships of ground-dwelling spiders (Araneae) to landscape features and to organic agriculture were studied in twelve pairs of organic versus conventional fields of winter wheat Triticum aestivum L. along a gradient of landscape complexity.

3. High percentages of non-crop habitats in the landscape increased local species richness of spiders from 12 to 20 species, irrespective of local management. This indicates that larger species pools are sustained in complex landscapes where there is higher availability of refuge and overwintering habitats.

4. Organic agriculture did not increase the number of spider species, but enhanced spider density by $62 \%$. Additionally, spider density was positively related to the percentage of noncrop habitats in the surrounding landscape, but only in conventional fields.

5. Synthesis and applications. The species richness of ground-dwelling spiders in crop fields was linked to large-scale landscape complexity, while spider densities responded to local management practices. Organic agriculture augments the numbers of predatory spiders, thereby contributing to pest control. However, measures to conserve species richness must also take landscape-scale factors into account. Complex landscapes with high amounts of perennial non-crop habitats should be preserved or restored to achieve high levels of spider diversity. Organic farming can be expected to benefit farmland spiders more strongly when it is applied to higher proportions of the landscape than it is currently the case.
\end{abstract}

\title{
Key words
}

Araneae, biodiversity, farm management, landscape complexity, organic farming, spatial ecology, winter wheat 


\section{Introduction}

Animal communities depend on both local conditions and features of the surrounding landscape (Ricklefs 1987). The role of the wider landscape in structuring animal communities may be particularly important in highly dynamic habitats such as annual crops (Kareiva \& Wennegren 1995; Weibull \& Östman 2003; Schmidt, Thies \& Tscharntke 2004; Tscharntke $\&$ Brandl 2004). A major threat to farmland biodiversity is the expansion of intensive arable crops in many European landscapes during the past decades, leaving structurally simplified landscapes with little non-crop habitat (Stoate et al. 2001; Benton, Vickery \& Wilson 2003). One consequence may be reduced diversity and abundance of invertebrate predators that may in turn reduce the natural control of important crop pests (Riechert \& Lawrence 1997; Schmidt et al. 2003). Nevertheless, landscape effects on local invertebrate species richness in farmland have remained relatively un-explored (Krebs et al. 1999). Recent exceptions are the positive effects of landscape complexity on the species richness of butterflies and ground beetles (Weibull \& Östman 2003), and on trap-nesting bees and wasps (Steffan-Dewenter 2002). Complex landscapes with high percentages of non-crop habitat can be expected to support more species than simple, crop-dominated landscapes. The movement of species between different habitats during their life cycle can lead to higher species richness in complex landscapes (Zobel 1997; Srivastava 1999). In agricultural landscapes, refuge habitats are of major importance for many arthropod populations during times when crops are disturbed (Landis, Wratten \& Gurr 2000; Sunderland \& Samu 2000), and most spider species that are typically found in crops during summer, emigrate from treated fields and overwinter predominantly in non-crop habitats (Marc, Canard \& Ysnel 1999; Thomas \& Jepson 1999; Thorbek \& Bilde 2004; Schmidt \& Tscharntke 2005a). Models have demonstrated how spider abundances can be enhanced by the availability of non-crop habitats on a landscape scale after events such as pesticide applications (Topping \& Sunderland 1994; Halley, Thomas \& Jepson 1996; Topping 1999). Hence, overall diversity and/or abundance may benefit from the availability of non-crop habitats in the landscape.

Organic farming aims to promote beneficial invertebrates by prohibiting the use of synthetic pesticides and mineral fertilizers. The positive influence on arable weeds is well documented (Menalled, Gross \& Hammond 2001; Hyvonen \& Salonen 2002), and densities of bats and dung beetles are higher on organic farms compared to conventional agriculture (Hutton \& Giller 2003; Wickramasinghe et al. 2003). Effects of organic farming on predacious arthropods are less clear (Glück \& Ingrisch 1990; Booij \& Noorlander 1992; Moreby et al. 1994; Feber et al. 1998; Pfiffner \& Luka 2003; Weibull \& Östman 2003; Hole et al. 2005). Pfiffner \& Niggli (1996) pitfall-trapped 108\%, 97\% and 161\% more spider individuals in organic than in conventional fields during three years. They found similar patterns in ground beetle (Coleoptera: Carabidae) and rove beetle numbers (Coleoptera: Staphylinidae), but did not test for differences in species richness. In addition, there is little information on whether 
landscape effects on arthropods differ between conventional and organic management (Östman, Ekbom \& Bengtsson 2001). Landscape effects may be stronger in conventional fields because arthropod populations depend more on immigration, or in organic fields because they can accommodate more immigrants. Here, we tested the relative influence of landscape effects and agricultural management on spiders in winter wheat fields using a paired-field approach along a gradient of landscape complexity. In particular, we examined which properties of the spider community are determined at the local and at the landscape scale.

\section{Material and methods}

\section{STUDY SITES}

In the study region around the city of Göttingen (Germany), twelve non-overlapping landscape sectors of $1.5 \mathrm{~km}$ radius were chosen along a gradient from structurally simple, with $>80 \%$ arable land, to structurally complex, with $>50 \%$ non-crop habitats. Simple and complex landscapes were spatially interspersed. In each landscape sector, one conventionally and one organically managed winter wheat field (according to EC Regulation 2092/91) was chosen, thus avoiding differences in landscape context between the two management styles. The pairs of organic and conventional fields were selected to be as similar as possible in all respects other than management. As potentially important local factors for spiders, diversity and percent cover of all weeds were recorded three times during the growing season on four plots of $3 \times 10 \mathrm{~m}$ per field. The detailed vegetation analyses will be described elsewhere (I. Roschewitz, unpublished data). Field size was not significantly different between conventional and organic fields $(3.9 \pm 0.6$ ha versus $3.1 \pm 0.4$ ha, $t=1.3, P=0.21)$. All studied fields were bordered by grassy margins that were mowed once per year. The majority of adjacent crops for both field types were conventional winter cereals. In organic fields, winter wheat was grown after a mixture of clover and grass, while the preceding crops of conventional winter wheat were mostly winter wheat and oilseed rape. Organic fields were fertilized with manure and weeds were controlled mechanically, while conventional farms applied mineral fertilizers, herbicides, fungicides and usually one insecticide spray in June. For details on conventional farming practices in the study region see Roschewitz, Thies \& Tscharntke (2005).

\section{SPIDER SAMPLING}

Spiders were sampled using four pitfall traps per field, arranged in a $10 \times 10 \mathrm{~m}$ square, two traps 15 and $25 \mathrm{~m}$ from the field edge, respectively. The traps consisted of $0.5 \mathrm{~L}$ plastic cups with an upper diameter of $8.8 \mathrm{~cm}$. Three centimetres beneath the top edge, pieces of wire mesh with $1.9 \mathrm{~cm}$ wide quadratic openings were inserted to prevent vertebrates from entering. 
Each trap was filled with $0.12 \mathrm{~L}$ of a mixture (1:2) of ethylene glycol (antifreeze) and water plus a few drops of detergent, and was protected from rain with $25 \times 25 \mathrm{~cm}$ acrylic glass roofs. The traps were operated twice for fourteen days, starting on 8 May and 28 June 2002. This follows the sampling scheme suggested by Duelli, Obrist \& Schmatz (1999) for collecting the maximal proportion of a full season catch with minimal effort. Catches were transferred to $80 \%$ ethanol. Pitfall trap catches reflect a combination of each species' abundance and likelihood to being trapped (largely determined by walking activity). We assume that numbers of individuals captured per field reflect between-field differences in absolute densities for each species (Topping \& Sunderland 1992). Juvenile spiders are underrepresented in pitfall traps, so that our results and conclusions hold predominantly for the populations of adults. Adult spiders were identified to species, and juveniles to family, the nomenclature following Platnick (2004). Females of Oedothorax apicatus and O. retusus were not distinguished. Species richness was calculated using only adult individuals.

\section{DATA ANALYSIS}

The percentage of all non-crop habitats within a radius of $1.5 \mathrm{~km}$ around the study fields was calculated as a measure of landscape complexity, based on official digital thematic maps (ATKIS - Digitales Landschaftsmodell 25/1; Landesvermessung und Geobasisinformation, Hannover, Germany 1991-1996). The percentages of other land-use types and their diversity were calculated for the same landscape sectors. Arable land covered on average $59 \%$, and non-crop habitats comprised mainly forest (21\%, predominantly deciduous), grassland (13\%, mainly hay meadows) and settlement (6\%, including gardens). Redundancy Analysis (RDA) was performed on square-root transformed spider densities to visualise similarities and differences of the assemblages occurring in the different fields. Correlations of environmental variables with the composition of the assemblage were tested using Monte-Carlo Permutations (MCP; ter Braak \& Smilauer 2002). Effects of (i) conventional versus organic management and (ii) the percentage of non-crop habitats in the surrounding landscape on species richness and density were analysed with general linear models (GLM; SAS proc mixed, SAS institute, Cary, NC, USA), using the two sampling periods as repeated measures and the landscapes (1-12) as random blocking factor. Non-significant interactions were backward eliminated, and the residuals checked for normal distribution. At the family and species level, Spearman's rank correlations and Wilcoxon's signed rank tests were used, because the assumptions for parametric tests were not always fulfilled. Increased probabilities of falsely rejecting null hypotheses in multiple comparisons were avoided by using Bonferroni corrections, and by calculating the overall probability for the observed frequency of outcomes falling below the nominal significance level $\alpha=0.05$ with Bernoulli equations (Moran 2003). Results were considered significant when at least one of these two criteria was met. Arithmetic means \pm standard errors are given in text and figures. 


\section{Results}

\section{SPIDER ASSEMBLAGES}

8013 spider individuals from 69 species were sampled, 7911 of which were adult (see details in Appendix). Spider assemblages of organic and conventional fields were separated on the first axis of the Redundancy Analysis (Fig. 1). Local management practices explained this difference (MCP: $F=2.4, P=0.01$ ), together with the directly related factors wheat stem density (higher in conventional fields), weed cover and weed species richness (both higher in organic fields). The second axis represented the landscape gradient. The percentage of noncrop habitats in the surrounding landscape was correlated to this community gradient, though only with marginal significance (MCP: $F=1.7, P=0.09$ ). Spider assemblages in the organic and in the conventional field of each landscape had similar scores on the second axis. Neither field size, the diversity of land-use types, the percentage of forest or grassland in the surrounding landscape showed significant correlations with the spider assemblages (MCP: $P$ $>0.1)$.

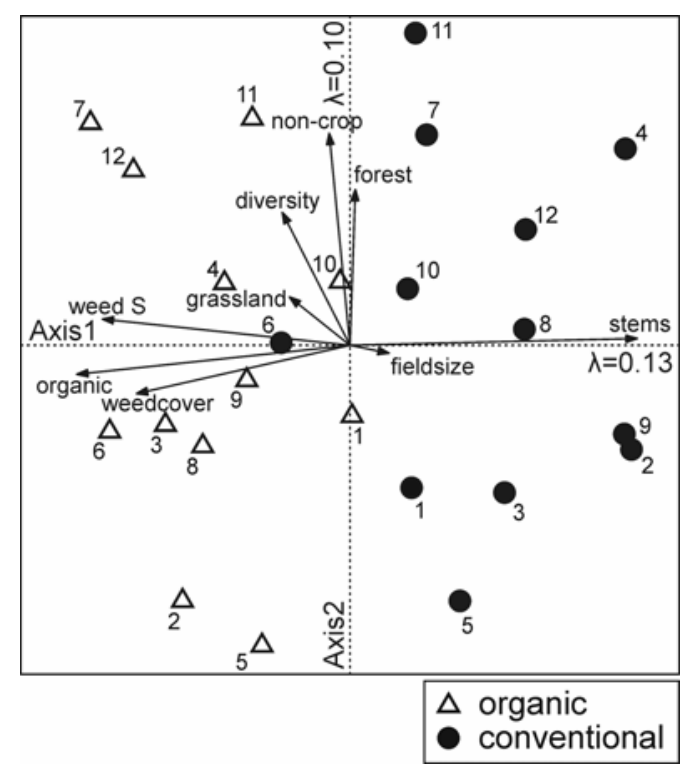

Figure 1. Ordination of spider assemblages in organic and conventional wheat fields in relation to environmental variables (RDA). Fields are numbered in the order of increasing percentages of non-crop habitat in the surrounding landscape. Arrows represent environmental variables: local organic management ('organic'), local weed species richness ('weed S'), local weed cover ('weedcover'), percentage of grassland in the surrounding landscape ('grassland'), diversity of land-use types in the surrounding landscape (Shannon-Wiener Index $\mathrm{H}_{\mathrm{S}}$; 'diversity'), percentage of non-crop habitats in the surrounding landscape ('non-crop'), percentage of forest in the surrounding landscape ('forest'), local field size ('fieldsize') and local density of wheat stems ('stems').

Spider densities were $62 \%$ higher in organic than in conventional fields (Fig. 2, Table 1). Additionally, densities during May were positively correlated to the percentage of surrounding non-crop habitats in conventional but not in organic fields (conventional $\mathrm{Y}=85$ $+1.86 \mathrm{X}, r=0.70, \alpha=0.012$, organic $\mathrm{Y}=228+0.47 \mathrm{X}, r=0.09, \alpha=0.78)$. To examine the 
positive effect of organic farming on spider densities more closely, the three genera captured in the highest numbers were tested separately (Table 2). Densities of the money spider Oedothorax spp. and the wolf spider Pardosa spp. were $88 \%$ and $103 \%$ higher in organic than in conventional fields, respectively. In contrast, densities of the commonly ballooning money spider Erigone spp. and the cumulated densities of all other genera were not significantly influenced by management.

Table 1. General linear models for effects of conventional versus organic management, the percentage of noncrop habitat in the surrounding landscape, and sampling date on density and species richness of spiders in winter wheat fields. Hyphens indicate non-significant interactions that have been backward eliminated.

\begin{tabular}{llccc}
\hline & Factor & d.f. & $F$ & $P$ \\
\hline \multirow{2}{*}{ Density } & management & 10 & 16.44 & 0.002 \\
& date & 11 & 0.14 & 0.71 \\
& management $\times$ date & - & - & - \\
& non-crop & 11 & 0 & 0.99 \\
& non-crop $\times$ management & - & - & - \\
non-crop $\times$ date & 11 & 6.36 & 0.028 \\
& management & & & 0.67 \\
& date & 10 & 0.19 & 0.65 \\
& management $\times$ date & 11 & 0.22 & - \\
& non-crop & - & - & - \\
& non-crop $\times$ management & 11 & 7.74 & 0.018 \\
& non-crop $\times$ date & - & - & - \\
& & 11 & 5.26 & 0.043 \\
\hline
\end{tabular}

Table 2. Effects of organic farming on the densities of the three most numerously captured spider genera. $t$-tests for matched pairs on average numbers per field pooled over both sampling dates.

\begin{tabular}{|l|c|c|c|c|c|}
\hline & Conventional & Organic & d.f. & $t$ & $P$ \\
\hline & & & & & \\
\hline Erigone spp. & $55 \pm 6$ & $67 \pm 13$ & 11 & -0.9 & 0.40 \\
\hline Oedothorax spp. & $101 \pm 25$ & $191 \pm 42$ & 11 & -3.3 & 0.007 \\
\hline Pardosa spp. & $49 \pm 14$ & $100 \pm 14$ & 11 & -4.7 & 0.001 \\
\hline other genera & $47 \pm 6$ & $50 \pm 8$ & 11 & -0.6 & 0.55 \\
\hline
\end{tabular}




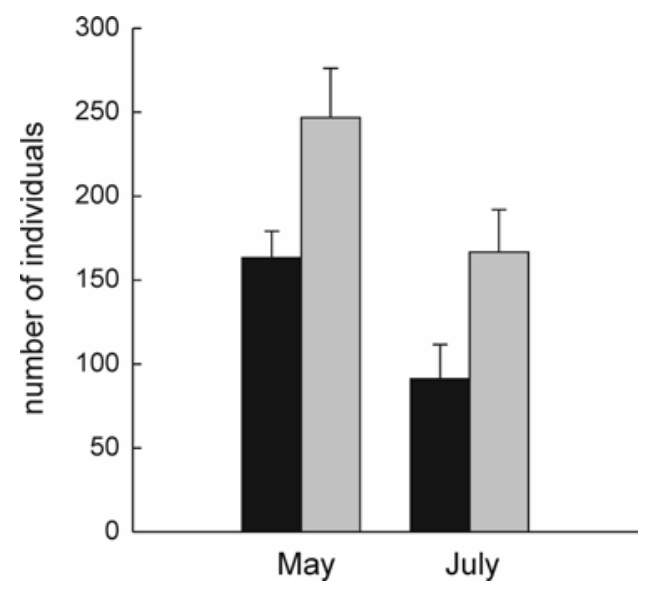

Figure 2. Spider density in conventional (black bars) versus organic (grey bars) winter-wheat fields in May (left) and July (right).
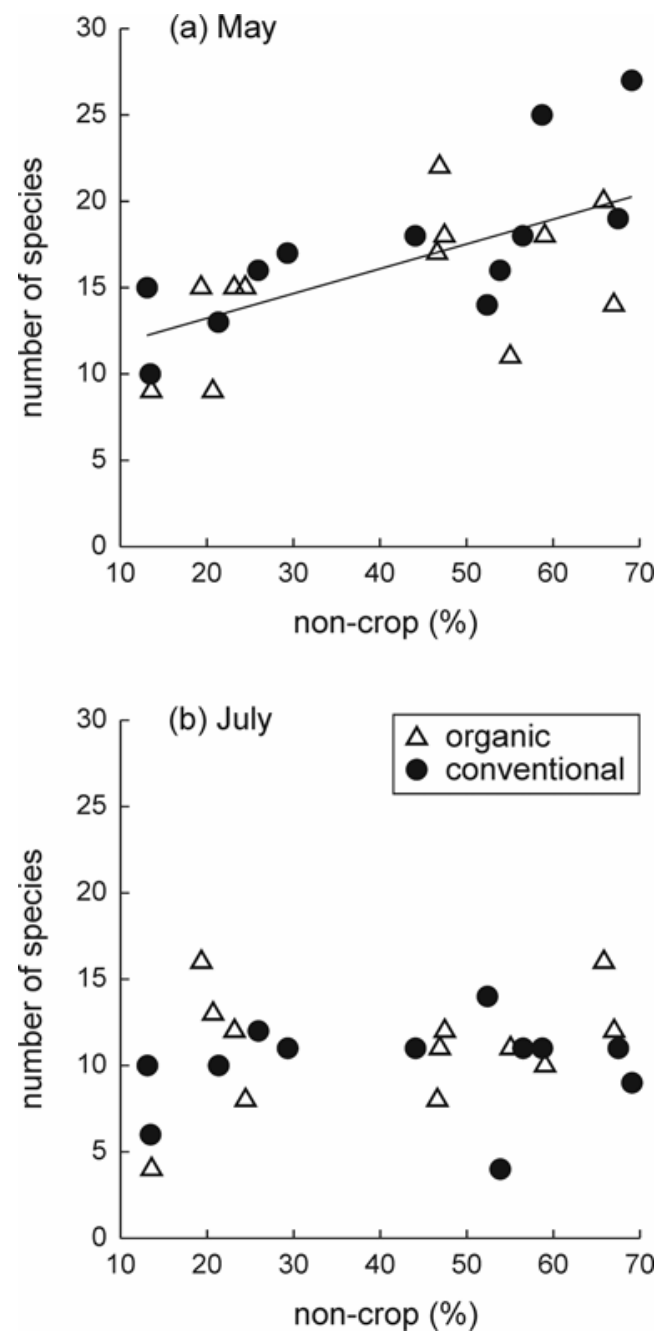

Figure 3. Correlations between the percentage of non-crop habitats and spider species richness in (a) May and (b) July. The regression line is fitted to the combined data of both field types. 
Species richness rose with high percentages of non-crop habitats in May (Fig. 3a; bivariate: Y $=10.4+0.14 \mathrm{X}, r=0.63, \alpha=0.001$; overall GLM: Table 1), but not in July (Fig. 3b; $r=0.19$, n.s.). Management did not influence species richness, nor did it interact with the effect of landscape complexity (Fig. 3, Table 1). The positive influence of non-crop habitats on species richness during May was not attributable to a particular (sub-) family (Table 3). While the correlation coefficients were positive for Erigoninae, Linyphiinae and Lycosidae, none of the correlations were significant. The pooled richness of the remaining families also showed a non-significant, but positive correlation to the percentage of non-crop habitats.

Table 3. Effects of the percentage of non-crop habitats in the surrounding landscape on local species richness of the three most speciose spider (sub-) families. Spearman's rank correlations on species richness in May pooled over one conventional and one organic field per landscape.

\begin{tabular}{|l|r|r|r|}
\hline & \multicolumn{1}{|c|}{ d.f. } & \multicolumn{1}{c|}{$r_{S}$} & \multicolumn{1}{c|}{$P$} \\
\hline Erigoninae & & & \\
\hline Linyphiinae & 11 & 0.47 & 0.12 \\
\hline Lycosidae & 11 & 0.50 & 0.096 \\
\hline other families & 11 & 0.44 & 0.15 \\
\hline
\end{tabular}

\section{SPIDER SPECIES}

In spite of the clear patterns at the assemblage level, there were few significant effects of landscape or management at the species level and over all 69 species there was no significant relationship between density and management (sign test: $Z=0.38, P=0.7$ ). Abundances between conventional and organic fields were compared using Wilcoxon's signed rank tests for the 27 species with six or more occurrences and four species showed significant differences $(\alpha<0.05)$. This number is greater than expected by chance within 27 comparisons according to the Bernoulli equation (overall $P=0.044$ ). Higher densities occurred in organic than in conventional fields in Oedothorax spp. females (d.f. $=11, Z=-2.6, \alpha=0.010$ ), Pardosa agrestis (d.f. $=11, Z=-2.1, \alpha=0.008$ ) and Pardosa amentata (d.f. $=11, Z=-2.4, \alpha$ $=0.017$; see Appendix). In contrast, Porrhomma microphthalmum (Linyphiinae) was captured only in conventional fields (d.f. $=11, Z=2.3, \alpha=0.024$ ). Three out of 20 species occurring in six or more landscapes showed significant correlations between densities in May and the percentage of non-crop habitats. Araeoncus humilis (d.f. $=11, r_{S}=0.65, \alpha=0.022$ ), Bathyphantes gracilis (d.f. $\left.=11, r_{S}=0.64, \alpha=0.025\right)$ and Trochosa terricola $\left(\right.$ d.f. $=11, r_{S}=$ $0.83, \alpha<0.001)$ were all captured in higher numbers in landscapes with high percentages of non-crop habitats. However, this number of nominally significant outcomes could be expected by chance (overall $P=0.075$ ) and only the $\alpha$-level of $T$. terricola lies below the Bonferroni-corrected level of 0.0025 . 


\section{Discussion}

The effects of landscape context and local management on spiders in cereal fields were differentiated in this study. The landscape context influenced species richness irrespective of management type, while organic and conventional fields differed in the composition of the spider assemblage, and in their overall density. The higher spider densities under organic management suggest more favourable habitat conditions. As spider habitats, organic fields may be superior to conventional fields in three respects. First, omitting pesticides may either directly reduce spider mortality, or increase food availability through a reduction in the mortality of spider prey. In the present study, no insecticides had been applied prior to the first spider sampling, but spider densities were already higher in organic than in conventional fields at that time. Therefore, insecticides alone could not have caused the observed difference. Secondly, spiders may benefit from higher weed populations in organic fields, which provide higher structural complexity and hideouts at the soil surface, and potentially increase the availability of herbivore prey. Cover of arable weeds was higher in the organic fields $(16.4 \pm 2.2 \%$ versus $6.2 \pm 3.1 \%$, I. Roschewitz unpublished data), potentially leading to the observed difference in spider density (Sunderland \& Samu 2000). Thirdly, while predominantly mineral fertilizers are used in conventional farming, organic fields receive manure and crop rotations include leguminous plants to improve soil quality. This may benefit spiders by increasing the availability of saprophagous insects such as springtails (Collembola) and midges (Diptera), which are among their most important prey groups (Alderweireldt 1994; Chen \& Wise 1999; Nyffeler 1999; Axelsen \& Kristensen 2000). In winter wheat, prey appears to be limiting especially in spring, and spider densities are higher where springtails are abundant (Harwood, Sunderland \& Symondson 2001).

The positive effects of organic farming were restricted to Pardosa spp. and Oedothorax spp., which predominantly walk into fields from their overwintering sites (Lemke \& Poehling 2002). In contrast, Erigone spp. and the majority of other spider species colonize crops by drifting through the air on threads of spider silk (Bishop \& Riechert 1990; Weyman, Sunderland \& Jepson 2002; Thomas, Brain \& Jepson 2003). Almost certainly, these ballooning species are unable to orientate themselves towards the more favourable organic fields, except through repeated assessment of habitat quality during a series of consecutive flights. This may explain why ballooning species appeared to be less affected by management, and suggests that the difference between conventional and organic fields may be due to differential immigration. Species richness was not enhanced by organic management, but only influenced by the surrounding landscape. However, both conventional and organic fields were mostly bordered by conventionally managed land, and only $1.7 \%$ of the arable land in the study region was organic (Niedersächsisches Landesamt für Statistik, personal communication). Therefore, further-reaching benefits could be expected if organic farming became more widespread and spanned more continuous tracts of the agricultural landscape. 
Species richness in wheat fields rose with the proportion of non-crop habitats in the surrounding landscape, with no apparent difference between organic and conventional management. Thus, spider communities in wheat fields were not saturated (Srivastava 1999; Loreau 2000), and fewer species arrived in wheat fields in crop-dominated landscapes. This suggests that fewer species exist in structurally simple landscapes (Landis et al. 2000, Sunderland \& Samu 2000). Alternatively, fields could have been too isolated from source habitats to be reached by certain species, but this seems unlikely as the distances from the traps to the next grassy field margin (small-scale heterogeneity) were equal in all study sites. As is typical for pitfall traps (Topping \& Sunderland 1992), our catches were dominated by wolf spiders (Lycosidae) and money spiders (Erigoninae). With the exception of Erigone atra and E. dentipalpis, commonly ballooning species were poorly represented (Weyman et al. 2002). Other important species in crops (the majority of Linyphiidae, Araneidae and Theridiidae) disperse more aerially and may respond differently to the landscape context than the ground-dwelling species in the current study (Halley et al. 1996; Thomas et al. 2003; Schmidt \& Tscharntke 2005b). Additional to the landscape effect on species richness, spider density in conventional fields during May was positively related to the percentage of non-crop habitats, approximating an $80 \%$ higher density in the most complex landscapes compared to the simplest ones. This suggests that density in conventional fields was determined by landscape-wide immigration processes, while organic fields developed more self-sustained populations.

\section{Conclusion}

Organic farming enhanced the density of ground-dwelling spiders in wheat fields, while high percentages of non-crop habitats mainly increased species richness particularly in late spring. Spiders are important predators in arable crops and the control of herbivores depends on high predator densities (Landis et al. 2000; Symondson, Sunderland \& Greenstone 2002; Schmidt et al. 2003). Hence, enhancement of spider numbers through organic farming may improve natural pest control and contribute to agricultural productivity (Östman, Ekbom \& Bengtsson 2003). Landscape complexity in this study enhanced spider diversity irrespective of management, and increased density in conventional fields. High percentages of non-crop habitats in the landscape may thereby alleviate the harmful effects of intensive agriculture on spider communities. As parasitoid wasps (Hymenoptera parasitica), ladybirds (Coleoptera: Coccinellidae) and ground beetles (Coleoptera: Carabidae) also benefit from landscape diversification, it becomes apparent that complex landscapes host generally more biological control agents (Elliott, Kieckhefer \& Beck 2002; Schmidt et al. 2004; Purtauf et al. 2005; Thies, Roschewitz \& Tscharntke 2005). In addition to local measures for natural enemy enhancement, complex landscapes with high amounts of perennial non-crop habitats should 
be preserved and developed to achieve high levels of biodiversity and pest control. Organic farming can be expected to benefit farmland spiders more strongly when it is applied to higher proportions of the landscape than it is currently the case.

\section{Acknowledgements}

We thank Christian Kluth for help with the statistics, Jason Tylianakis for linguistic advice and Oliver-David Finch and Theo Blick for checking spider identifications. Paul Giller, David McCracken and several anonymous referees gave valuable comments on earlier drafts of this manuscript. Financial support came from the German Science Foundation (DFG) and the German Ministry for Research and Education (BMBF). MHS was supported by the German National Academic Foundation (Studienstiftung des deutschen Volkes).

\section{References}

Alderweireldt, M. (1994) Prey selection and prey capture strategies of Linyphiid spiders in high-input agricultural fields. Bulletin of the British Arachnological Society, 9, 300-308.

Axelsen, J.A. \& Kristensen, K.T. (2000) Collembola and mites in plots fertilised with different types of green manure. Pedobiologia, 44, 556-566.

Benton, T.G., Vickery, J.A. \& Wilson, J.D. (2003) Farmland biodiversity: is habitat heterogeneity the key? Trends in Ecology and Evolution, 18, 182-188.

Bishop, L. \& Riechert, S. E. (1990) Spider colonization of agroecosystems: mode and source. Environmental Entomology, 19, 1738-1745

Booij, C.J.H. \& Noorlander, J. (1992) Farming systems and insect predators. Agriculture, Ecosystems and Environment, 40, 125-135.

Chen, B.R. \& Wise, D.H. (1999) Bottom-up limitation of predaceous arthropods in a detritusbased food web. Ecology, 80, 761-772.

Duelli P., Obrist M.K. \& Schmatz D.R. (1999) Biodiversity evaluation in agricultural landscapes: above-ground insects. Agriculture, Ecosystems and Environment, 74, 33-64.

Elliott, N.C., Kieckhefer, R.W. \& Beck, D.A. (2002) Effect of aphids and the surrounding landscape on the abundance of Coccinellidae in cornfields. Biological Control, 24, $214-$ 220.

Feber, R.E., Bell, J., Johnson, P.J., Firbank, L.G. \& Macdonald, D.W. (1998) The effects of organic farming on surface-active spider (Araneae) assemblages in wheat in southern England (UK). Journal of Arachnology, 26, 190-202.

Glück, E. \& Ingrisch, S. (1990) The effect of bio-dynamic and conventional agriculture management on Erigoninae and Lycosidae spiders. Journal of Applied Entomology, 110, 136-148. 
Halley, J.M., Thomas, C.F.G. \& Jepson, P.C. (1996) A model for the spatial dynamics of linyphiid spiders in farmland. Journal of Applied Ecology, 33, 471-492.

Harwood, J.D., Sunderland, K.D. \& Symondson, W.O.C. (2001) Living where the food is: web location by linyphiid spiders in relation to prey availability in winter wheat. Journal of Applied Ecology, 38, 88-99.

Hole, D.G., Perkins, A.J., Wilson, J.D., Alexander, I.H., Grice, P.V. \& Evans, A.D. (2005) Does organic farming benefit biodiversity? Biological Conservation, 122, 113-130.

Hutton, S.A. \& Giller, P.S. (2003) The effects of the intensification of agriculture on northern temperate dung beetle communities. Journal of Applied Ecology, 40, 994-1007.

Hyvonen, T. \& Salonen, J. (2002) Weed species diversity and community composition in cropping practices at two intensity levels - a six-year experiment. Plant Ecology, 159, 73-81.

Kareiva, P. \& Wennegren, U. (1995) Connecting landscape patterns to ecosystem and population processes. Nature, 373, 299-302.

Krebs, J.R., Wilson, J.D., Bradbury, R.B. \& Siriwardena, G.M. (1999) The second silent spring? Nature, 400, 611-612.

Landis, D.A., Wratten, S.D. \& Gurr, G.M. (2000) Habitat management to conserve natural enemies of arthropod pests in agriculture. Annual Review of Entomology, 45, 175-201.

Lemke, A. \& Poehling, H.-M. (2002) Sown weed strips in cereal fields: overwintering site and "source" habitat for Oedothorax apicatus (Blackwall) and Erigone atra (Blackwall) (Araneae: Erigonidae). Agriculture, Ecosystems and Environment, 90, 67-80.

Loreau, M. (2000) Are communities saturated? On the relationship between $\alpha, \beta$ and $\gamma$ diversity. Ecology Letters, 3, 73-76.

Marc P., Canard A. \& Ysnel F. (1999) Spiders (Araneae) useful for pest limitation and bioindication. Agriculture, Ecosystems and Environment, 74, 229-273

Menalled, F.D., Gross, K.L. \& Hammond, M. (2001) Weed aboveground and seedbank community responses to agricultural management systems. Ecological Applications, 11, 1586-1601.

Moran, M.D. (2003) Arguments for rejecting the sequential Bonferroni in ecological studies. Oikos, 100, 403-405.

Moreby, S.J., Aebischer, N.J., Southway, S.E. \& Sotherton, N.W. (1994) A comparison of the flora and arthropod fauna of organically and conventionally grown winter wheat in southern England. Annals of Applied Biology, 125, 13-27.

Nyffeler, M. (1999) Prey selection of spiders in the field. Journal of Arachnology, 27, $317-$ 324.

Östman, Ö., Ekbom, B. \& Bengtsson, J. (2001) Farming practice and landscape heterogeneity influence biological control. Basic and Applied Ecology, 2, 365-371.

Östman, Ö., Ekbom, B. \& Bengtsson, J. (2003) Yield increase attributable to aphid predation by ground-living polyphagous natural enemies in spring barley in Sweden. Ecological 
Economics, 45, 149-158.

Pfiffner, L. \& Luka, H. (2003) Effects of low-input farming systems on carabids and epigeal spiders - a paired farm approach. Basic and Applied Ecology, 4, 117-127.

Pfiffner, L. \& Niggli, U. (1996) Effects of bio-dynamic, organic and conventional farming on ground beetles (Col. Carabidae) and other epigaeic arthropods in winter wheat. Biological Agriculture and Horticulture, 12, 353-364.

Platnick, N.I. (2004) The world spider catalog, version 4.5. American Museum of Natural History, online at http://research.amnh.org/entomology/spiders/catalog/index.html.

Purtauf, T., Roschewitz, I., Dauber, J., Thies, C., Tscharntke, T. \& Wolters, V. (2005) Landscape context of organic and conventional farms: influences on carabid beetle diversity. Agriculture, Ecosystems \& Environment, in press.

Ricklefs, R.E. (1987) Community diversity: relative roles of local and regional processes. Science, 235, 167-171.

Riechert, S.E. \& Lawrence, K. (1997) Test for predation effects of single versus multiple species of generalist predators: spiders and their insect prey. Entomologia Experimentalis et Applicata, 84, 147-155.

Roschewitz, I., Thies, C. \& Tscharntke, T. (2005) Are landscape complexity and farm specialisation related to land-use intensity of annual crop fields? Agriculture, Ecosystems and Environment, 105, 87-99.

Schmidt, M.H., Lauer, A., Purtauf, T., Thies, C., Schaefer, M. \& Tscharntke, T. (2003) Relative importance of predators and parasitoids for cereal aphid control. Proceedings of the Royal Society of London, Series B: Biological Sciences, 270, 1905-1909.

Schmidt, M.H., Thies, C. \& Tscharntke, T. (2004) Landscape context of arthropod biological control. Ecological Engineering for Pest Management: Advances in Habitat Manipulation for Arthropods (eds G.M. Gurr, S.D. Wratten \& M.A. Altieri), pp. 55-63. CSIRO, Collingwood VIC.

Schmidt, M.H. \& Tscharntke, T. (2005a) The role of perennial habitats for Central European farmland spiders. Agriculture, Ecosystems and Environment, 105, 235-242.

Schmidt, M.H. \& Tscharntke, T. (2005b) Landscape context of sheetweb spider (Araneae: Linyphiidae) abundance in cereal fields. Journal of Biogeography, in press.

Srivastava, D.S. (1999) Using local-regional richness plots to test for species saturation: pitfalls and potentials. Journal of Animal Ecology, 68, 1-16.

Steffan-Dewenter, I. (2002) Landscape context affects trap-nesting bees, wasps, and their natural enemies. Ecological Entomology, 27, 631-637.

Stoate, C., Boatman, N.D., Borralho, R.J., Carvalho, C.R., de Snoo, G.R. \& Eden, P. (2001) Ecological impacts of arable intensification in Europe. Journal of Environmental Management, 63, 337-365.

Sunderland, K.D. \& Samu, F. (2000) Effects of agricultural diversification on the abundance, distribution, and pest control potential of spiders: a review. Entomologia Experimentalis 
et Applicata, 95, 1-13.

Symondson, W.O.C., Sunderland, K.D. \& Greenstone, H.M. (2002) Can generalist predators be effective biocontrol agents? Annual Review of Entomology, 47, 561-594.

ter Braak, C.J.F. \& Smilauer, P. (2002) CANOCO Reference Manual and CanoDraw for Windows User's Guide: Software for Canonical Community Ordination (version 4.5). Microcomputer Power, Ithaca, NY.

Thies, C., Roschewitz, I. \& Tscharntke, T. (2005) The landscape context of cereal aphidparasitoid interactions. Proceedings of the Royal Society of London, Series B: Biological Sciences, in press.

Thomas, C.F.G. \& Jepson, P.C. (1999) Differential aerial dispersal of linyphiid spiders from a grass and a cereal field. Journal of Arachnology, 27, 294-300.

Thomas, C.F.G., Brain, P. \& Jepson, P.C. (2003) Aerial activity of linyphiid spiders: modelling dispersal distances from meteorology and behaviour. Journal of Applied Ecology, 40, 912-927.

Thorbek, P. \& Bilde, T. (2004) Reduced numbers of generalist arthropod predators after crop management. Journal of Applied Ecology, 41, 526-539.

Topping, C.J. (1999) An individual-based model for dispersive spiders in agroecosystems: simulations of the effects of landscape stucture. Journal of Arachnology, 27, 378-386.

Topping, C.J. \& Sunderland, K.D. (1992) Limitations in the use of pitfall traps in ecological studies exemplified by a study of spiders in a field of winter wheat. Journal of Applied Ecology, 29, 485-491.

Topping, C.J. \& Sunderland, K.D. (1994) A spatial population dynamics model for Lepthyphantes tenuis (Araneae: Linyphiidae) with some simulations of the spatial and temporal effects of farming operations and land-use. Agriculture, Ecosystems and Environment, 48, 203-217.

Tscharntke, T. \& Brandl, R. (2004) Plant-insect interactions in fragmented landscapes. Annual Review of Entomology, 49, 405-430.

Weibull, A.C. \& Östman, Ö. (2003) Species composition in agroecosystems: the effect of landscape, habitat, and farm management. Basic and Applied Ecology, 4, 349-361.

Weyman, G.S., Sunderland, K.D. \& Jepson, P.C. (2002) A review of the evolution and mechanisms of ballooning by spiders inhabiting arable farmland. Ethology, Ecology and Evolution, 14, 307-326.

Wickramashinghe, L.P., Harris, S., Jones, G. \& Vaughan, N. (2003) Bat activity and species richness on organic and conventional farms: impact of agricultural intensification. Journal of Applied Ecology, 40, 984-993.

Zobel, M. (1997) The relative role of species pools in determining plant species richness: an alternative explanantion of species coexistence? Trends in Ecology and Evolution, 12, 266-269. 
Appendix. Average number of spider individuals captured in conventional and organic fields $(n=12$; mean \pm S.E.).

\begin{tabular}{|c|c|c|c|}
\hline (Sub-) Family & Species & Conventional & Organic \\
\hline Dictynidae & Cicurina cicur & $0.1 \pm 0.1$ & $0.0 \pm 0.0$ \\
\hline \multirow[t]{29}{*}{ Erigoninae } & Araeoncus humilis & $0.8 \pm 0.3$ & $0.8 \pm 0.3$ \\
\hline & Ceratinella brevis & $0.1 \pm 0.1$ & $0.0 \pm 0.0$ \\
\hline & Collinsia inerrans & $0.7 \pm 0.4$ & $1.7 \pm 1.1$ \\
\hline & Dicymbium nigrum brevisetosum & $0.6 \pm 0.3$ & $0.3 \pm 0.2$ \\
\hline & Diplocephalus latifrons & $0.4 \pm 0.2$ & $0.0 \pm 0.0$ \\
\hline & Dismodicus bifrons & $0.1 \pm 0.1$ & $0.0 \pm 0.0$ \\
\hline & Erigone atra & $46.3 \pm 5.3$ & $51.1 \pm 8.6$ \\
\hline & Erigone dentipalpis & $8.2 \pm 1.5$ & $16.3 \pm 5.4$ \\
\hline & Erigonella hiemalis & $0.1 \pm 0.1$ & $0.1 \pm 0.1$ \\
\hline & Gongylidiellum latebricola & $0.1 \pm 0.1$ & $0.1 \pm 0.1$ \\
\hline & Gongylidiellum vivum & $0.1 \pm 0.1$ & $0.1 \pm 0.1$ \\
\hline & Leptorhoptrum robustum & $1.0 \pm 0.3$ & $1.6 \pm 0.8$ \\
\hline & Micrargus herbigradus & $0.2 \pm 0.1$ & $0.0 \pm 0.0$ \\
\hline & Micrargus subaequalis & $0.6 \pm 0.2$ & $0.2 \pm 0.2$ \\
\hline & Oedothorax apicatus, males & $29.7 \pm 6.3$ & $43.3 \pm 6.9$ \\
\hline & Oedothorax fuscus & $1.3 \pm 0.5$ & $4.8 \pm 2.6$ \\
\hline & Oedothorax retusus, males & $3.6 \pm 1.5$ & $4.3 \pm 1.1$ \\
\hline & Oedothorax spp., females & $66.8 \pm 19.4$ & $138.5 \pm 35.3$ \\
\hline & Parapelecopsis nemoralis & $0.1 \pm 0.1$ & $0.0 \pm 0.0$ \\
\hline & Pocadicnemis juncea & $0.0 \pm 0.0$ & $0.1 \pm 0.1$ \\
\hline & Tapinocyba insecta & $0.0 \pm 0.0$ & $0.1 \pm 0.1$ \\
\hline & Tiso vagans & $0.1 \pm 0.1$ & $0.2 \pm 0.2$ \\
\hline & Walckenaeria atrotibialis & $0.3 \pm 0.3$ & $0.3 \pm 0.1$ \\
\hline & Walckenaeria capito & $0.1 \pm 0.1$ & $0.0 \pm 0.0$ \\
\hline & Walckenaeria dysderoides & $0.1 \pm 0.1$ & $0.2 \pm 0.1$ \\
\hline & Walckenaeria nudipalpis & $0.2 \pm 0.1$ & $0.2 \pm 0.1$ \\
\hline & Walckenaeria unicornis & $0.0 \pm 0.0$ & $0.1 \pm 0.1$ \\
\hline & Walckenaeria vigilax & $1.8 \pm 0.8$ & $2.7 \pm 0.8$ \\
\hline & immatures & $0.1 \pm 0.1$ & $0.3 \pm 0.2$ \\
\hline \multirow[t]{7}{*}{ Gnaphosidae } & Drassylus lutetianus & $0.1 \pm 0.1$ & $0.0 \pm 0.0$ \\
\hline & Drassylus praeficus & $0.1 \pm 0.1$ & $0.0 \pm 0.0$ \\
\hline & Drassylus pusillus & $0.3 \pm 0.1$ & $0.1 \pm 0.1$ \\
\hline & Haplodrassus signifer & $0.2 \pm 0.2$ & $0.1 \pm 0.1$ \\
\hline & Haplodrassus umbratilis & $0.1 \pm 0.1$ & $0.0 \pm 0.0$ \\
\hline & Micaria pulicaria & $0.0 \pm 0.0$ & $0.1 \pm 0.1$ \\
\hline & Zelotes latreillei & $0.1 \pm 0.1$ & $0.0 \pm 0.0$ \\
\hline
\end{tabular}




\begin{tabular}{|c|c|c|c|}
\hline (Sub-) Family & Species & Conventional & Organic \\
\hline \multirow[t]{2}{*}{ Hahniidae } & Antistea elegans & $0.0 \pm 0.0$ & $0.1 \pm 0.1$ \\
\hline & Hahnia nava & $0.1 \pm 0.1$ & $0.1 \pm 0.1$ \\
\hline \multirow[t]{11}{*}{ Linyphiinae } & Bathyphantes gracilis & $2.7 \pm 0.7$ & $1.3 \pm 0.4$ \\
\hline & Centromerita bicolor & $0.2 \pm 0.2$ & $0.0 \pm 0.0$ \\
\hline & Centromerus cavernarum & $0.1 \pm 0.1$ & $0.0 \pm 0.0$ \\
\hline & Centromerus sylvaticus & $0.0 \pm 0.0$ & $0.1 \pm 0.1$ \\
\hline & Diplostyla concolor & $0.4 \pm 0.3$ & $0.0 \pm 0.0$ \\
\hline & Meioneta rurestris & $0.7 \pm 0.3$ & $0.8 \pm 0.4$ \\
\hline & Ostearius melanopygius & $0.1 \pm 0.1$ & $0.0 \pm 0.0$ \\
\hline & Porrhomma errans & $0.4 \pm 0.3$ & $0.3 \pm 0.1$ \\
\hline & Porrhomma microphthalmum & $0.8 \pm 0.3$ & $0.0 \pm 0.0$ \\
\hline & Tenuiphantes tenuis & $4.4 \pm 1.0$ & $3.9 \pm 0.8$ \\
\hline & Tenuiphantes zimmermanni & $0.1 \pm 0.1$ & $0.0 \pm 0.0$ \\
\hline \multirow[t]{14}{*}{ Lycosidae } & Alopecosa cuneata & $1.8 \pm 1.2$ & $3.4 \pm 2.8$ \\
\hline & Alopecosa pulverulenta & $4.7 \pm 1.3$ & $5.3 \pm 1.6$ \\
\hline & Pardosa agrestis & $2.2 \pm 0.8$ & $11.8 \pm 5.5$ \\
\hline & Pardosa amentata & $24.9 \pm 9.7$ & $51.7 \pm 12.4$ \\
\hline & Pardosa lugubris & $1.1 \pm 0.8$ & $0.6 \pm 0.6$ \\
\hline & Pardosa monticola & $0.0 \pm 0.0$ & $0.1 \pm 0.1$ \\
\hline & Pardosa palustris & $11.2 \pm 3.7$ & $24.3 \pm 6.2$ \\
\hline & Pardosa pullata & $9.8 \pm 3.2$ & $11.2 \pm 3.3$ \\
\hline & Pirata latitans & $0.0 \pm 0.0$ & $0.1 \pm 0.1$ \\
\hline & Pirata uliginosus & $0.1 \pm 0.1$ & $0.0 \pm 0.0$ \\
\hline & Trochosa ruricola & $3.8 \pm 0.9$ & $4.9 \pm 1.8$ \\
\hline & Trochosa spinipalpis & $0.1 \pm 0.1$ & $0.0 \pm 0.0$ \\
\hline & Trochosa terricola & $2.2 \pm 1.3$ & $1.5 \pm 0.6$ \\
\hline & immatures & $2.8 \pm 0.8$ & $4.8 \pm 1.6$ \\
\hline \multirow[t]{4}{*}{ Tetragnathidae } & Pachygnatha clercki & $4.5 \pm 1.6$ & $2.8 \pm 0.8$ \\
\hline & Pachygnatha degeeri & $10.8 \pm 2.0$ & $16.3 \pm 4.0$ \\
\hline & Tetragnatha pinicola & $0.0 \pm 0.0$ & $0.1 \pm 0.1$ \\
\hline & immatures & $0.0 \pm 0.0$ & $0.3 \pm 0.2$ \\
\hline \multirow[t]{3}{*}{ Theridiidae } & Neottiura bimaculata & $0.0 \pm 0.0$ & $0.1 \pm 0.1$ \\
\hline & Robertus lividus & $0.3 \pm 0.2$ & $0.0 \pm 0.0$ \\
\hline & Robertus neglectus & $0.1 \pm 0.1$ & $0.0 \pm 0.0$ \\
\hline \multirow[t]{3}{*}{ Thomisidae } & Xysticus cristatus & $0.2 \pm 0.1$ & $0.4 \pm 0.3$ \\
\hline & Xysticus kochi & $0.3 \pm 0.2$ & $0.0 \pm 0.0$ \\
\hline & immatures & $0.1 \pm 0.1$ & $0.0 \pm 0.0$ \\
\hline Zoridae & Zora spinimana & $0.1 \pm 0.1$ & $0.0 \pm 0.0$ \\
\hline
\end{tabular}




\title{
Chapter 6
}

\section{The landscape context of cereal aphid-parasitoid interactions}

\author{
Carsten Thies, Indra Roschewitz \& Teja Tscharntke
}

Proceedings of the Royal Society of London Series B 272 (2005) 203-210

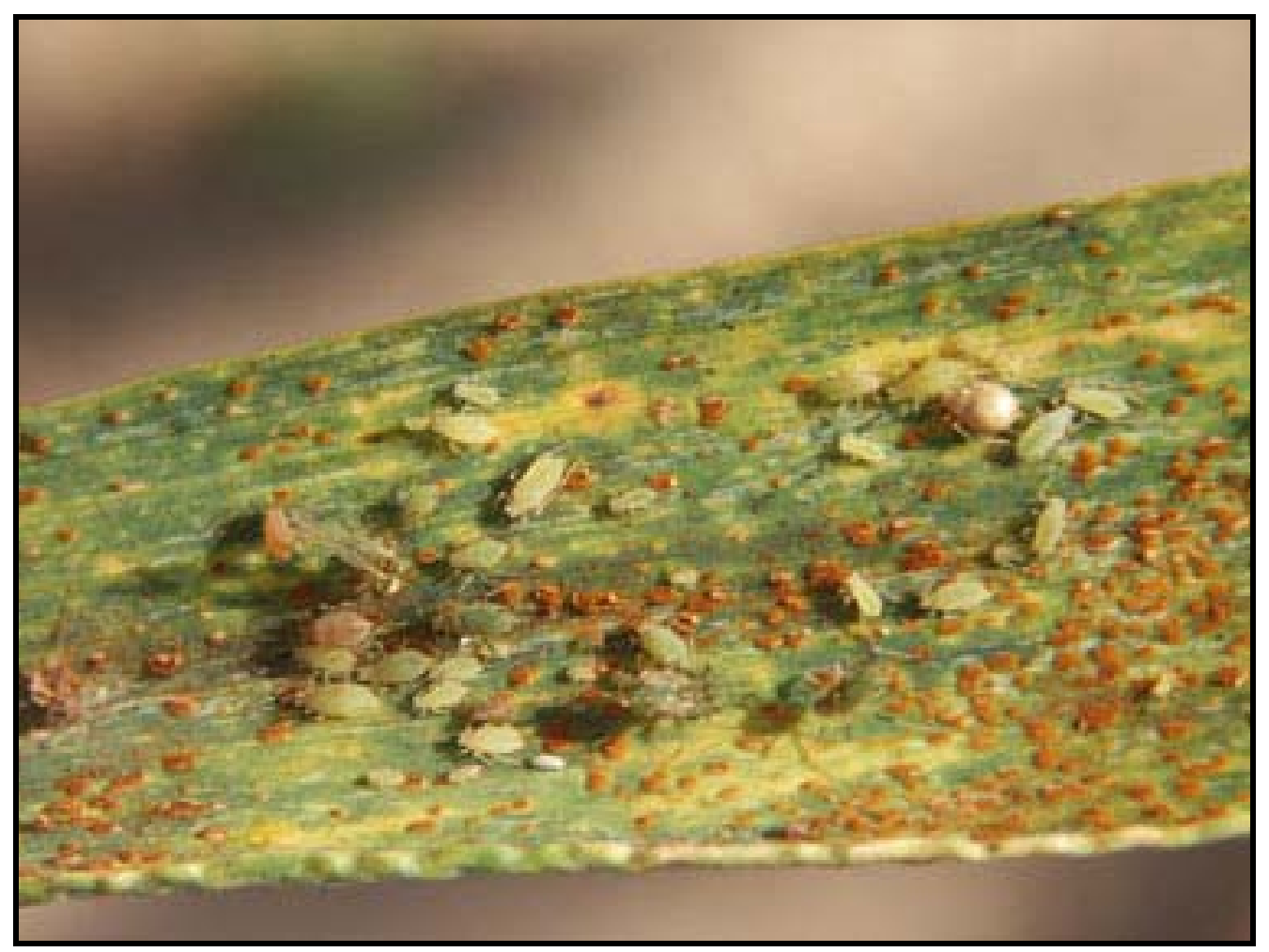




\begin{abstract}
Analyses at multiple spatial scales may show how important ecosystem services such as biological control are determined by processes acting on the landscape scale. We examined cereal aphid-parasitoid interactions in wheat fields in agricultural landscapes differing in structural complexity (32-100\% arable land). Complex landscapes were associated with increased aphid mortality resulting from parasitism, but also with higher aphid colonization, thereby counterbalancing possible biological control by parasitoids and lastly resulting in similar aphid densities across landscapes. Thus, undisturbed perennial habitats appeared to enhance both pests and natural enemies. Analyses at multiple spatial scales (landscape sectors of $0.5-6 \mathrm{~km}$ diameter) showed that correlations between parasitism and percentage of arable land were significant at scales of $0.5-2 \mathrm{~km}$, whereas aphid densities responded to percentage of arable land at scales of $1-6 \mathrm{~km}$ diameter. Hence, the higher trophic level populations appeared to be determined by smaller landscape sectors owing to dispersal limitation, showing the 'functional spatial scale' for species-specific landscape management.
\end{abstract}

\title{
Key words
}

Biological control; wheat; landscape structure; spatial ecology; temporal changes 


\section{Introduction}

Understanding of population dynamics needs analyses of trophic interactions at multiple spatial and temporal scales (Kareiva 1990; Pimm 1991; Wiens et al. 1993; Kareiva \& Wennergren 1995; Pickett \& Cadenasso 1995; Rosenzweig 1995; Holt 1996; Roland \& Taylor 1997; Wiens et al. 1997; Tischendorf \& Fahrig 2000; Cadenasso \& Pickett 2000; Ricketts 2001; Menalled et al. 2003; Tscharntke \& Brandl 2004). Spatial and temporal dynamics should be particularly important in agricultural landscapes, which are dominated by arable fields. Annual harvesting and soil cultivation almost completely erase herbivores and their natural enemies, so that arable fields have to be recolonized from surrounding habitats yearly. Nevertheless, annual crops can exhibit strong regulation of herbivore populations by natural enemies (Halaj \& Wise 2001), this being improved by both changing agricultural practices within crop fields (Wratten \& van Emden 1995; Van Driesche \& Bellows 1996), and the management of agricultural landscapes (Altieri 1995; Burel \& Baudry 1995; Van Driesche \& Bellows 1996; Matson et al. 1997; Menalled et al. 1999; Thies \& Tscharntke 1999; Tscharntke \& Kruess 1999; Tscharntke 2000; Östman et al. 2001; Tscharntke et al. 2002; Van Nouhuys \& Hanski 2002a). A basic understanding of the mechanisms of naturally occurring biological control may contribute to the management of environmentally sound crop production systems that use ecosystem services and reduce external effects such as those due to pesticides (Tilman et al. 2002).

In winter wheat fields (Triticum aestivum L.) in northern Germany, the herbivore community is dominated by three species of cereal aphids (Homoptera, Aphididae), Sitobion avenae (Fabricius), Metopolophium dirhodum (Walker) and Rhopalosiphum padi (Linnaeus). Outbreaks of aphid populations causing economic damage have been recorded since the early 1970s. They have been related to increased applications of nitrogen fertilizers in combination with applications of growth regulators and fungicides, which protect the leaf structure (Hanisch 1980; Ankersmit 1988; Honek 1991a). The role of natural enemies in preventing cereal aphid outbreaks is emphasized in several studies (e.g. Wratten \& Powell 1991; Levie et al. 2000; Kindlmann \& Dixon 2001; Sigsgaard 2002; Schmidt et al. 2003), but little is known about whether variability of bio-control can be explained by the surrounding landscape (but see Östman et al. 2001). The landscape context connects to local processes via dispersal and thereby should be expected to filter differences in the species traits such as body size, foraging range, resource specialization, population size variability and trophic position (Holt 1996; Tscharntke \& Brandl 2004).

In this three-year study, we analysed changes in the population size of cereal aphids and their mortality owing to parasitism at multiple spatial scales. Our former analyses of experimental exclusion of aphid enemies showed that parasitoids (Hymenoptera: mainly Aphidiidae) that are specialized on one or several aphid host species (Sigsgaard 2002), could best explain differences in aphid densities (Schmidt et al. 2003). However, flying and ground-dwelling 
predators can also be important (see Holland et al. 1996; Holland \& Thomas 1997; Östman et al. 2001; Lang 2003). The fields were located in agricultural landscapes characterized by a gradient from structurally complex landscapes to structurally simple ones (32-100\% arable land that was closely correlated with habitat type diversity). The influence of landscape context on aphid-parasitoid interactions was tested from small to large landscape scales, in that we tested seven circular landscape sectors ranging from 0.5 to $6 \mathrm{~km}$ diameter. We expected that (i) aphid parasitism would decrease and aphid densities increase with increasing percentage of arable land in a landscape and (ii) that aphids and their parasitoids would respond to landscape context at different spatial scales.

\section{Material and methods}

The three-year study was conducted in altogether 40 conventionally managed winter wheat fields in the vicinity of the city of Göttingen ( $51^{\circ} 32^{\prime} \mathrm{N}, 9^{\circ} 56^{\prime} \mathrm{E}$; see Steffan-Dewenter et al. 2002, Thies et al. 2003), Lower Saxony (North Germany) in the years 2001 ( $N=18$ fields), 2002 ( $N=10$ fields), and 2003 ( $N=12$ fields), which differed between years due to crop rotation. The area is dominated by arable fields with intensive agricultural land use (ca. 75\% of the region) and patchily distributed fragments of forests, grasslands, fallows, hedges and other semi-natural habitats. The area under cultivation was composed of cereals (71\%), sugar beets $(12 \%)$, oilseed rape $(8 \%)$, and corn (4\%) (I. R., unpublished data). The average temperature $\left({ }^{\circ} \mathrm{C}\right)$ and total rain fall $(\mathrm{mm})$ during the study periods from June to July differed notably (June 2001: $13.9^{\circ} \mathrm{C}, 59.9 \mathrm{~mm}$; June 2002: $16.6^{\circ} \mathrm{C}, 71.4 \mathrm{~mm}$; June 2003: $18.1^{\circ} \mathrm{C}$, 47.7mm; and July 2001: $18.4^{\circ} \mathrm{C}, 68.8 \mathrm{~mm}$; July 2002: $17.3^{\circ} \mathrm{C}, 95.2 \mathrm{~mm}$; July $2003: 18.7^{\circ} \mathrm{C}$; $46.9 \mathrm{~mm}$; data from the meteorological station in Göttingen).

The study sites were located in a gradient from structurally simple landscapes (up to $100 \%$ arable land) to structurally complex landscapes $(<35 \%$ arable land). The distribution of landscapes of different complexity did not show any north-south or east-west pattern, to avoid spatial autocorrelation in abiotic factors such as soil fertility. For each of the fields the surrounding proportion of habitat types was measured at seven circular sectors of increasing diameter ( $\varnothing 0.5 \mathrm{~km}$; $\varnothing 1 \mathrm{~km}$; $\varnothing 2 \mathrm{~km} ; \varnothing 3 \mathrm{~km}$; $\varnothing 4 \mathrm{~km}$; $\varnothing 5 \mathrm{~km}$; $\varnothing 6 \mathrm{~km}$ ) representing a nested set of landscape sectors at seven spatial scales. Landscape data were available for 39 (of the 40) landscape sectors. We quantified the area of arable land, grassland, forests, hedgerows, garden land, and settlement using official digital thematic maps (ATKISDigitales Landschaftsmodell 25/1; Landesvermessung und Geobasisinformation, Hannover, Germany 1991-1996) and the Geographical Information System ArcView 3.1 (ESRI Geoinformatik GmbH, Hannover, Germany) at these seven spatial scales. The percentage of arable land per landscape was used as an indicator for landscape complexity as annual ploughing and harvesting in crops may greatly affect most organisms and this simple 
parameter has been shown to be a good predictor for other landscape metrics such as habitat type diversity and habitat isolation (Thies \& Tscharntke 1999, Steffan-Dewenter et al. 2002). Land-use intensity of the fields, i.e. the amount of nitrogen fertilizers ( $\mathrm{kg} \mathrm{N}$ per ha) and pesticides (number of applications of herbicides, fungicides, insecticides, and growth regulators per year), which was recorded in a questionnaire of farmers in 2001 ( $N=18$ fields), was not related to landscape complexity. For example, percent arable land in a landscape sector of $1 \mathrm{~km}$ diameter was not related to (i) nitrogen: $208.1 \pm 28.1 \mathrm{~kg}$ N per ha, $R_{S}=0.282, P=$ 0.244; (ii) herbicides: $1.9 \pm 0.5$ applications per year, $R_{S}=-0.218, P=0.369$; (iii) fungicides: $1.9 \pm 0.8$ applications per year, $R_{S}=0.336, P=0.167$; (iv) insecticides: $0.7 \pm 0.6$ applications per year, $R_{S}=0.288, P=0.235$; or (v) growth regulators: $1.7 \pm 0.7$ applications per year, $R_{S}=0.207$, $P=0.394$ (means $\pm S D$; Spearman rank correlations $\left(R_{S}\right)$; I.R., unpublished data).

Aphids and parasitized aphids (mummies) were quantified visually on an insecticide-free area of $800 \mathrm{~m}^{2}$ in each of the 40 fields on 100 wheat shoots per field at wheat flowering in June (after the main period of aphid colonisation of the fields), and on 100 wheat shoots per field at wheat milk-ripening in July (after the main period of aphid reproduction in the fields). Each of the 80 samples consisted of four subsamples of 25 shoots of different locations, which added to 100 shoots. In the first year, aphid mummies were additionally sampled (two hours per field) and taken into the laboratory for rearing and identification of the parasitoid genera. The effects of the predictor variables "year", "host plant density", and "percent arable land" on aphid densities, and the effects of the predictor variables "year", "host density", and "percent arable land" on aphid parasitism were analysed individually for each of the seven spatial scales (i.e. landscape sectors) using general linear models (following Wiegand et al. 1999, Steffan-Dewenter et al. 2002, Thies et al. 2003; for theoretical background, see Hanski 1998; Legendre \& Legendre 1998; Turner et al. 2001; Holland et al. 2004). Model assumptions were tested by examining the normality of the residuals (Sokal \& Rohlf 1995). The skewness and/or kurtosis of the data was compensated by $\log _{(X+1)}$-transformation of aphid densities, and $\operatorname{arcsine}\left(V_{X}\right)$-transformation of parasitism rates. In addition, Spearman rank correlations $\left(R_{S}\right)$ were used to analyse the relationship between aphid population growth (the proportion of aphid density at wheat milk-ripening $\left(d_{\mathrm{wmr}}\right)$ and aphid density at wheat flowering $\left.\left(d_{\mathrm{wfl}}\right)=d_{\mathrm{wmr}} / d_{\mathrm{wfl}}\right)$ and percent parasitism at the second sample date. Arithmetic means \pm standard deviation $(S D)$ are given. 


\section{Results}

A total of 12234 cereal aphid individuals was counted in 40 winter wheat fields, of which 69.4\% were Sitobion avenae, 27.4\% Metopolophium dirhodum, and 3.2\% Rhopalosiphum padi. Aphids were attacked by five genera of parasitoids (mainly Aphidius; Aphidinidae), and the latter by three genera of hyperparasitoids (mainly Dendrocerus; Megaspilidae). The population densities of aphids and their parasitoids are summarized in Table 1; they varied considerably between the 40 study sites. Aphid and parasitoid densities were positively correlated at wheat flowering $\left(F_{1,38}=10.0, P=0.003, N=40, R=0.456\right)$, but not at wheat milkripening $\left(F_{1,38}=0.01, P=0.913, N=40, R=0.031\right)$.

Table 1. Densities of cereal aphids and parasitoid mummies (individuals per 100 shoots) in winter wheat fields in three consecutive years. Arithmetic means \pm standard deviations $(S D)$, minima, and maxima are given for 18 fields in year 2001, for 10 fields in year 2002, and for 12 fields in year 2003.

\begin{tabular}{|c|c|c|c|}
\hline & Mean \pm SD & Min. & Max. \\
\hline \multicolumn{4}{|c|}{ No. of aphids at wheat flowering } \\
\hline Year 2001 & $23.7 \pm 14.5$ & 1 & 53 \\
\hline Year 2002 & $257.6 \pm 161.7$ & 30 & 596 \\
\hline Year 2003 & $121.7 \pm 63.9$ & 7 & 229 \\
\hline \multicolumn{4}{|c|}{ No. of aphids at wheat milk-ripening } \\
\hline Year 2001 & $46.9 \pm 32.2$ & 13 & 140 \\
\hline Year 2002 & $101.6 \pm 63.9$ & 18 & 228 \\
\hline Year 2003 & $492.6 \pm 297.4$ & 258 & 1371 \\
\hline \multicolumn{4}{|c|}{ No. of mummies at wheat flowering } \\
\hline Year 2001 & $0.9 \pm 1.5$ & 0 & 5 \\
\hline Year 2002 & $5.8 \pm 5.4$ & 0 & 14 \\
\hline Year 2003 & $0.3 \pm 0.6$ & 0 & 2 \\
\hline \multicolumn{4}{|c|}{ No. of mummies at wheat milk-ripening } \\
\hline Year 2001 & $8.8 \pm 6.4$ & 0 & 23 \\
\hline Year 2002 & $13.2 \pm 8.1$ & 4 & 26 \\
\hline Year 2003 & $8.0 \pm 6.0$ & 0 & 23 \\
\hline
\end{tabular}

Aphid densities averaged 111.6 \pm 127.8 individuals per 100 shoots at wheat flowering and $194.3 \pm 258.8$ individuals per 100 shoots at milk-ripening. They increased from wheat flowering to milk-ripening stage in 2001 and 2003, but not in 2002 (Table 1), thereby exceeding the threshold level of economic damage (3-5 per shoot; Pflanzenschutzamt Hannover 2002) in $0 \%$ of the fields in $2001,40 \%$ of the fields in 2002 , and $100 \%$ of the fields in 2003. Aphid densities differed significantly between years on both dates (Table 2). At wheat flowering, they correlated negatively with percent arable land at scales between $\varnothing 1 \mathrm{~km}$ 
and $\varnothing 6 \mathrm{~km}$. At milk-ripening, this relationship was not significant at any scale (Table 2; Fig. $1 \mathrm{~A}-\mathrm{C})$.

Table 2. F-values and levels of significance from General Linear Models relating aphid densities and aphid parasitism rates in wheat fields to three predictive factors: (i) the year of the survey, (ii) the percentage of arable land per landscape sector at seven spatial scales, and (iii) host plant density and host density, respectively.

\begin{tabular}{|c|c|c|c|c|c|c|c|}
\hline & \multicolumn{7}{|c|}{ Diameter of landscape sector } \\
\hline & $0.5 \mathrm{~km}$ & $1 \mathrm{~km}$ & $2 \mathrm{~km}$ & $3 \mathrm{~km}$ & $4 \mathrm{~km}$ & $5 \mathrm{~km}$ & $6 \mathrm{~km}$ \\
\hline \multicolumn{8}{|c|}{ Aphids per 100 shoots at wheat flowering: } \\
\hline A: Year & $28.3^{\star \star *}$ & $39.1^{* * *}$ & $40.5^{* * *}$ & $37.1^{* * *}$ & $36.6^{* * *}$ & $36.5^{* * *}$ & $34.8^{* \star *}$ \\
\hline B: Arable land (\%) & n.s. & $10.2^{* *}$ & $12.3^{\star *}$ & $9.9^{* *}$ & $9.4^{* *}$ & $9.5^{\star *}$ & $8.9^{* *}$ \\
\hline C: Host plant density & n.s. & n.s. & n.s. & n.s. & n.s. & n.s. & n.s. \\
\hline $\mathrm{A} \times \mathrm{B}$ & n.s. & n.s. & n.s. & n.s. & n.s. & n.s. & n.s. \\
\hline$A \times C$ & n.s. & n.s. & n.s. & n.s. & n.s. & n.s. & n.s. \\
\hline $\mathrm{B} \times \mathrm{C}$ & n.s. & n.s. & n.s. & n.s. & n.s. & n.s. & n.s. \\
\hline Model & $28.3^{* * *}$ & $26.1^{* * *}$ & $27.9^{* \star *}$ & $25.9^{* * *}$ & $25.5^{\star * *}$ & $25.6^{* * *}$ & $25.0^{* * *}$ \\
\hline \multicolumn{8}{|c|}{ Aphids per 100 shoots at wheat milk-ripening: } \\
\hline A: Year & $53.1^{* \star \star}$ & $53.1^{* * *}$ & $53.1^{* * *}$ & $53.1^{* * *}$ & $53.1^{* * *}$ & $53.1^{* * *}$ & $53.1^{* * *}$ \\
\hline B: Arable land (\%) & n.s. & n.s. & n.s. & n.s. & n.s. & n.s. & n.s. \\
\hline C: Host plant density & n.s. & n.s. & n.s. & n.s. & n.s. & n.s. & n.s. \\
\hline$A \times B$ & n.s. & n.s. & n.s. & n.s. & n.s. & n.s. & n.s. \\
\hline$A \times C$ & n.s. & n.s. & n.s. & n.s. & n.s. & n.s. & n.s. \\
\hline $\mathrm{B} \times \mathrm{C}$ & n.s. & n.s. & n.s. & n.s. & n.s. & n.s. & n.s. \\
\hline Model & $53.1^{* * *}$ & $53.1^{* * *}$ & $53.1^{* * *}$ & $53.1^{* * *}$ & $53.1^{* * *}$ & $53.1^{* * *}$ & $53.1^{* * *}$ \\
\hline \multicolumn{8}{|c|}{ Aphid parasitism (\%) at wheat milk-ripening: } \\
\hline A: Year & $7.2^{* *}$ & $3.9^{*}$ & $3.8^{*}$ & n.s. & n.s. & n.s. & n.s. \\
\hline B: Arable land (\%) & n.s. & $12.3^{* *}$ & $9.6^{* *}$ & n.s. & n.s. & n.s. & n.s. \\
\hline C: Host density & n.s. & $18.8^{* * *}$ & $18.4^{* * *}$ & $57.2^{* \star *}$ & $57.2^{* * *}$ & $57.2^{* \star *}$ & $57.2^{\star \star \star}$ \\
\hline$A \times B$ & $6.9^{*}$ & n.s. & n.s. & n.s. & n.s. & n.s. & n.s. \\
\hline$A \times C$ & n.s. & $5.6^{*}$ & $5.4^{*}$ & n.s. & n.s. & n.s. & n.s. \\
\hline $\mathrm{B} \times \mathrm{C}$ & $34.9^{* * *}$ & n.s. & n.s. & n.s. & n.s. & n.s. & n.s. \\
\hline Model & $19.8^{* * *}$ & $18.6^{* * *}$ & $15.9^{\star * *}$ & $57.2^{\star \star \star}$ & $57.2^{\star \star *}$ & $57.2^{\star \star *}$ & $57.2^{* * *}$ \\
\hline
\end{tabular}

Note: ${ }^{* * * P<0.001 ; * * P<0.01 ; * P<0.05}$.

Aphid parasitism was low at wheat flowering with an average of $2.6 \pm 5.6 \%$ and increased at wheat milk-ripening to $15.9 \pm 15.8 \%$ (for absolute densities, see Table 1). At wheat milkripening, parasitism differed significantly between years, and correlated negatively with percent arable land and host density (Table 2). In contrast to aphid abundance, the variation in parasitism explained by percent arable land was only significant between scales of $\varnothing 0.5 \mathrm{~km}$ and $\varnothing 2 \mathrm{~km}$ diameter of landscape sector (Table 2; Fig. 1D-F). At the smallest spatial scale ( $\varnothing$ $0.5 \mathrm{~km})$, the negative effect of percent arable land on parasitism occurred mainly when host density was low (interaction: arable land $\times$ host density), and differed between years, being 
marked only in year 2001 and 2002 (interaction: year $\times$ arable land). At scales of $\varnothing 1 \mathrm{~km}$ and $2 \mathrm{~km}$, arable land and host density accounted for main effects, but the effect of local host densities also differed between years, being marked in 2001 and 2002 (interaction: year $\times$ host density).
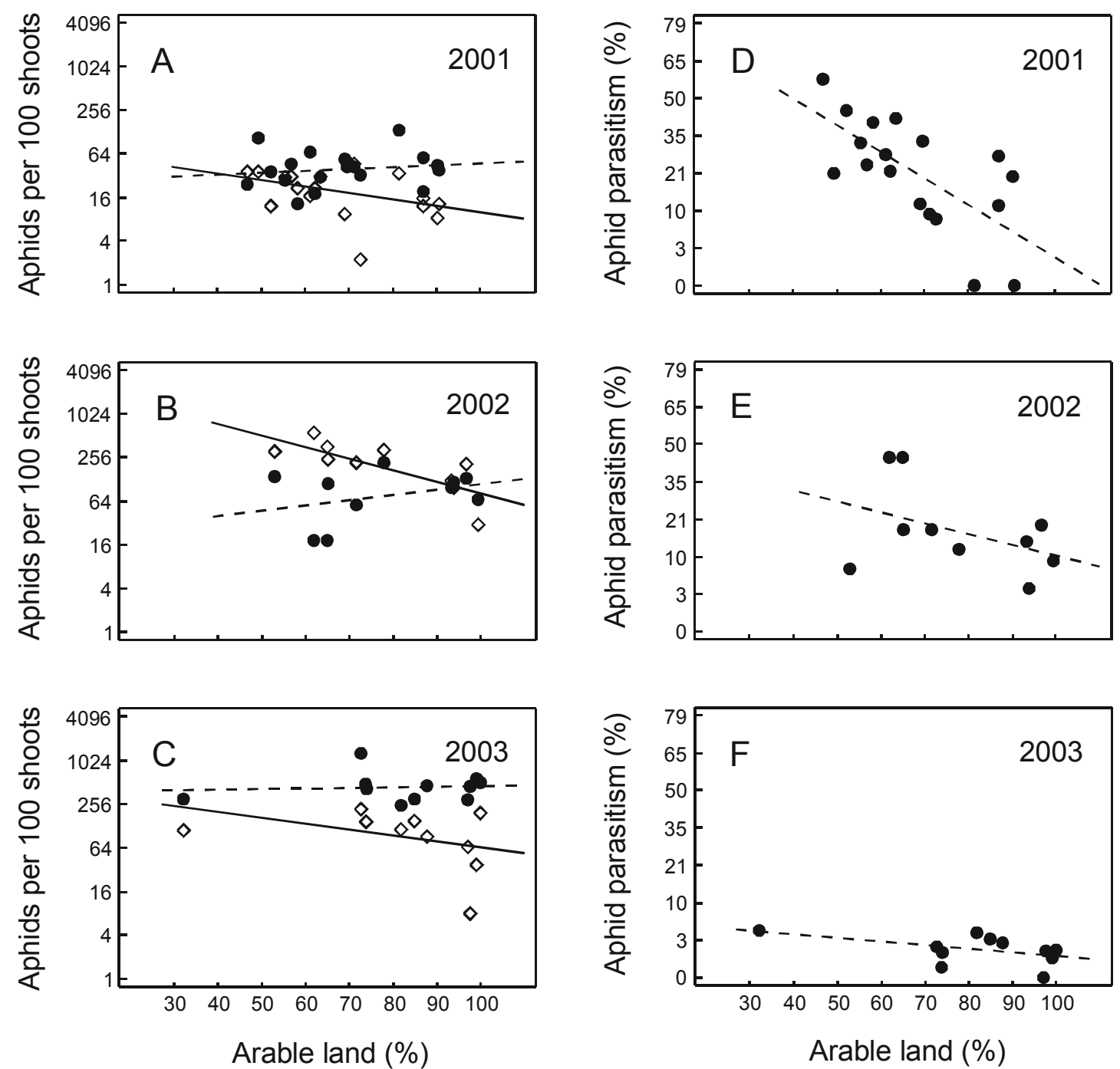

Figure 1. Dependence of cereal aphid densities (A-C) and percent parasitism (D-F) on the percentage of arable land within circular landscape sectors of $1 \mathrm{~km}$ diameter in three consecutive years. Open quadrats and solid lines: wheat flowering stage in June (after the main period of aphid colonisation of the fields); filled points and dashed lines: wheat milk-ripening stage in July (after the main period of aphid reproduction in the fields). Regression lines are shown for descriptive purpose. Statistics see table 3. Note the logarithmic scale for aphid densities. 
Aphid population growth correlated negatively with parasitism (Fig. 2). Aphid populations decreased between wheat flowering and milk ripening at parasitism rates higher than $27 \%$, which were found in landscapes with $>30 \%$ noncrop area. The negative correlation between aphid population growth and parasitism rate occured in each year (Year 2001: $P=0.019, N=$ 18, $R_{S}=-0.571$; Year 2002: $P=0.031, N=10, R_{S}=-0.720$; Year 2003: $P=0.060, N=12, R_{S}=-$ $0.566) .34 \%$ of the mummies reared in the laboratory were hyperparasitoids.

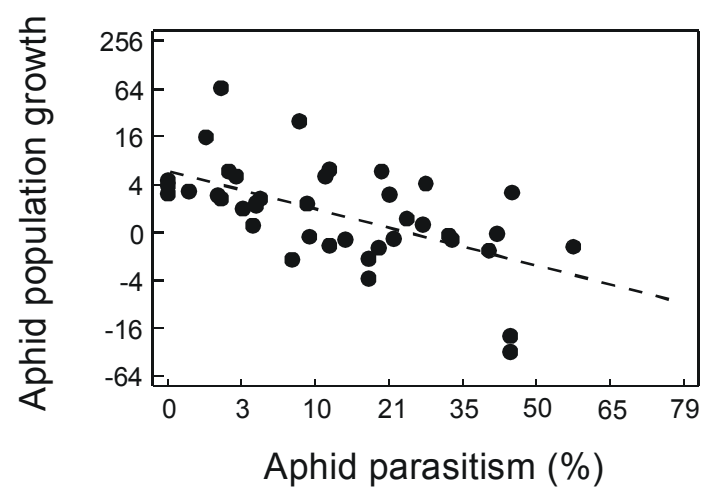

Figure 2. Relation of aphid population growth (the proportion of aphid density at wheat milk-ripening $\left(d_{\text {wmr }}\right)$ and aphid density at wheat flowering $\left.\left(d_{\mathrm{wfl}}\right)=d_{\mathrm{wmr}} / d_{\mathrm{wfl}}\right)$ to percent parasitism. Spearman rank correlation: $P<0.001$, $N=40, R_{S}=-0.547$.

\section{Discussion}

The analyses of population density and parasitism of cereal aphids showed that trophic interactions in wheat fields varied greatly between years and were associated with the landscape context at different spatial scales. Non-crop area in the complex landscapes appeared to support larger parasitoid populations, but aphids also profited from complex landscapes, thereby counterbalancing possible biological control of aphids by parasitoids. Aphid densities after colonisation at wheat flowering stage were higher in structurally complex landscapes than in structurally simple landscapes. But, they did substantially increase between wheat flowering and milk-ripening only in structurally simple landscapes, thereby resulting in no differences in aphid densities between landscapes after aphid reproduction. As high rates of parasitism could only be found in structurally complex landscapes with relatively little area of annual crop fields, the parasitoid wasps were most likely to have contributed to the suppression of aphid densities in these landscapes. This implication is supported by the overall negative correlation between aphid population growth and parasitism, and by recent field experiments in our landscapes indicating the great importance of naturally occurring cereal aphid parasitoids (Schmidt et al. 2003). A regulation of cereal aphids by parasitoids released into field cages was also found by Levie et al. (2000), and suggested by other studies reporting similar high rates of cereal aphid parasitism (e.g. Sigsgaard 2002). However, our results showed that parasitism strongly decreased with host 
density, and parasitoids therefore should be expected to successfully control the aphids only in situations of lower aphid densities. The rates of hyperparasitism that we found reached $34 \%$. Hyperparasitoids mainly act later in the season, namely in the period when aphid population densities break down due to decreasing resource quality. Nevertheless, they may influence primary parasitoid densities in the following year (Sunderland et al. 1997). Several studies suggest that hyperparasitoids reduce the potential control of herbivore populations by primary parasitoids (reviewed by Rosenheim 1998).

Both aphid populations and their parasitoids appeared to have profited from structurally complex landscapes due to a high availability of perennial habitats providing shelter from disturbances by agricultural practices, overwintering sites, and alternative host plants and hosts. The cereal aphid S. avenae hibernates on perennial grasses (Leather 1993), which represent a dominant plant family in many perennial habitats. $M$. dirhodum and $R$. padi are host alternating on Rosa spp. and Prunus padus, respectively, which are common plant species only in structurally rich landscapes. In addition, other aphid species could be expected to act as a reservoir of cereal aphid parasitoids such as Acyrthosiphum pisum, which is a key aphid on legumes and known to be highly parasitzed by Aphidius sp. (Stary 1976, 1978). Therefore, undisturbed perennial areas should support both high aphid densities and large parasitoid populations, whereas high proportions of arable land should disadvantage these organisms. Overwintering sites for parasitoids adjacent to crop fields are known to increase egg parasitism of grape leafhoppers (Corbett \& Rosenheim 1996) and larval parasitism of the rape pollen beetle (Thies \& Tscharntke 1999). Moreover, our structurally complex landscapes provide more nectar sources for adult parasitoids due to a larger cover of flowering plants (Steffan-Dewenter et al. 2001), and there are several examples of enhanced parasitism and extended parasitoid lifetimes by augmented nectar resources (Powell 1986, Wäckers \& Swaans 1993; Wratten \& van Emden 1995; Wäckers 1994; Wäckers \& Steppuhn 2003).

Cereal aphid populations are expected to profit from higher temperatures causing higher immigration and reproduction rates, but to suffer from rain fall events resulting in lower survival rates (Triltsch et al. 1998; Gosselke et al. 2001; for other host-parasitoid systems, see e.g. Godfray et al. 1994, Kaitaniemi \& Ruohomaki 1999, Van Nouhuys \& Lei 2004). In accordance with these findings, our results showed mean aphid densities to be higher in 2002 and 2003, years with higher average temperatures, and population development to be lower in 2002, possibly due to heavy rain falls in June and July 2002 (two events with $38.5 \mathrm{~mm}$ and $36.7 \mathrm{~mm}$ per day, respectively, in the period of aphid reproduction). The relative role of interannual weather changes (e.g. Palmer \& Räisänen 2002; Hansen 2004) for aphid-natural enemy interactions is not well known yet, but changing temperatures and rain fall events might be expected to be important, because they were related to aphid densities (negatively density-dependent parasitism). Weather conditions are also suggested to influence the aphid control by generalist predators early in the season (Chiverton et al. 1986; Lang 2003). 
The geographic scale analyses supported the expectation that species experience the spatial scale of landscape complexity differentially. The predictive power of landscape complexity for aphid parasitism was only significant within smaller landscape sectors of $0.5-2 \mathrm{~km}$ diameter. This is in support of the hypothesis that parasitoids often show dispersal limitation (Kruess \& Tscharntke 1994, 2000; Tscharntke \& Kruess 1999; With et al. 1999; but see Van Nouhuys \& Hanski 2002b), and could be related to the relatively small body size of the parasitoids, which is a general predictor of how organisms acquire resources in space (Roland \& Taylor 1997; Ritchie \& Olff 1999). In contrast, the cereal aphids responded to differences in landscape context within landscape sectors up to $6 \mathrm{~km}$. This is in line with expectations from host-alternating species like cereal aphids (but not parasitoids), as such multi-habitat use should be associated with high dispersal abilities. In addition, this supports findings of other studies that ascribed much importance to long-distance dispersal of aphids of tens or even hundreds of kilometers (Taylor 1977; Halbert et al. 1990; Riley et al. 1995).

In conclusion, structurally complex landscapes showed the highest rates of aphid parasitism, but they also enhanced aphid populations, thereby counterbalancing possible control of this major pest, and resulting in an overall neutral effect of landscape context. Hence, the often stressed argument for conservation or recreation of undisturbed perennial habitats in agricultural landscapes may not generally hold for biological control. Further, parasitoid populations responded to changes of landscape context at smaller scales than their aphid hosts, thereby supporting the idea that spatially explicit approaches may provide a perspective to identify "functional spatial scales" at which species experience their environment, and at which species-specific landscape management may be arranged to enhance biological control. The striking differences in aphid abundance and their interactions with parasitoids between years call for more long-term experiments to better understand the relative role of spatial and temporal factors that shape local ecological processes.

\section{Acknowledgements}

F.J.J.A Bianchi, P. Kindlmann, A. Kruess, M.H. Schmidt, and T. Rand contributed with discussions, two anonymous reviewers with helpful comments, and C. Bürger, J. Dauber, D. Gabriel, M. Hücker, W. Koehler, J. Morzfeld, T. Purtauf, L. Reimer, U. Visser, K. Wiegand, S. Vidal, and V. Wolters with a productive collaboration within the project BIOPLEX (Biodiversity and spatial complexity in agricultural landscapes under global change). Financial support came from the German Ministry for Research and Education (Bundesministerium für Bildung und Forschung) and the German Science Foundation (Deutsche Forschungsgemeinschaft). 


\section{References}

Ankersmit, G. W. 1988 Integrated control of cereal aphids. In: World crop pests: aphids (ed Helle, W.). Elsevier, Amsterdam, pp. 273-278.

Altieri, M. A. 1995 Agroecology. Westview Press, Boulder.

Burel, F. \& Baudry, J. 1995 Farming landscapes and insects. In: Ecology and integrated farming systems (eds Glen, D. M., Greaves, M. P. \& Anderson, H. P.). John Wiley \& Sons, Chichester, pp. 203-220.

Cadenasso, M. L. \& Pickett, S. T. A. 2000 Linking forest edge structure to edge function: mediation to herbivore damage. J. Ecol. 88, 31-44.

Chiverton, P. A. 1986 Predator density manipulation and its effects on the populations of Rhopalosiphum padi (Hom. Aphididae) in spring barley. Ann. Appl. Biol. 109, 49-60.

Corbett, A. \& Rosenheim, J. A. 1996 Impact of natural enemy overwintering refuge and its interaction with the surrounding landscape. Ecol. Entomol. 21, 155-164.

Godfray, H. C. J., Hassell, M. P. \& Holt, R. D. 1994 The population-dynamic consequences of phenological asynchrony between parasitoids and their hosts. J. Anim. Ecol. 63, 1-10.

Gosselke, U., Triltsch, H., Roßberg, D. \& Freier, B. 2001 GETLAUS01 - the latest version of a model simulating aphid population dynamics in dependence on antagonists in wheat. Ecol. Model. 145, 143-157.

Halaj, J. \& Wise, D. H. 2001 Terrestrial trophic cascades: how much do they trickle? Am. Nat. 157, 262-281.

Halber, S. Connelly, J. \& Sandvol, L. 1990 Suction trapping of aphids in western NorthAmerica (emphasis on Idaho). Acta Phytopathol. Hun. 25, 411-422.

Hanisch, H. C. 1980 Einfluß unterschiedlich hoher Stickstoffdüngung zu Weizen auf die Populationsentwicklung von Getreideblattläusen. Z. Pflkrank. PflSchutz 87, 546-556.

Hansen, J. 2004 Defusing the global warming time bomb. Sci. Am. 290, 68-77.

Hanski, I. 1998 Metapopulation dynamics. Nature 396: 41-49.

Holland, J. M. \& Thomas, S. R. 1997 Quantifying the impact of polyphagous invertebrate predators in controlling cereal aphids and in preventing wheat yield and quality reductions. Ann. Appl. Biol. 131, 375-397.

Holland, J. M., Thomas, S. R. \& Hewitt, A. 1996 Some effects of polyphagous predators on an outbreak of cereal aphid (Sitobion avenae F.) and orangewheat blossom midge (Sitodoplosis mosellana Gehin). Agr. Ecosyst. Environ. 59, 181-190.

Holland, J. D., Bert, D. G. \& Fahrig, L. 2004 Determining the spatial scale of species' response to habitat. BioScience 54: 227-233.

Holt, R. D. 1996 Food webs in space: An island biogeographic perspective. In: Food webs integration of patterns and dynamics (eds Polis, G. A. \& Winemiller, K. O.). Chapman \& Hall, New York, pp. 313-323. 
Honek, A. 1991 Nitrogen fertilization and abundance of the cereal aphids Metopolophium dirhodum and Sitobion avenae (Homoptera, Aphididae). Z. PflKrank. PflSchutz 98, 655660 .

Kaitaniemi, P \& Ruohomaki, K. 1999 Effects of autum temperature and oviposition date on timing of larval development and risk of parasitism in a spring folivore. Oikos 84, 435442.

Kareiva, P. 1990 Population dynamics in spatially complex environments: theory and data. Phil. Trans. R. Soc. Lond. B 330, 175-190.

Kruess, A. \& Tscharntke, T. 1994 Habitat fragmentation, species loss, and biological control. Science 264, 1581-1584.

Kruess, A. \& Tscharntke, T. 2000 Species richness and parasitism in a fragmented landscape: experiments and field studies with insects on Vicia sepium. Oecologia 122: 129-137.

Kindlmann, P. \& Dixon, A. F. G. 2001 When and why top-down regulation fails in arthropod predator-prey systems. Basic Appl. Ecol. 2, 333-340.

Lang, A. 2003 Intraguild interferences and biocontrol effects of generalist predators in a winter wheat field. Oecologia 134, 144-153.

Leather, S. R. 1993 Overwintering in six arable aphid pests: a review with particular relevance to pest management. J. Appl. Ent. 116, 217-233.

Legendre, P. \& Legendre, L. 1998 Numerical ecology, Elsevier, Amsterdam.

Levie, A., Dogot, P. \& Hance, T. 2000 Release of Aphidius rhopalosiphi (Hymenoptera: Aphidiinae) for cereal aphid control: field cage experiments. Eur. J. Entomol. 97, 527531.

Losey, J. E. \& Denno, R. F. 1998 Positive predator-predator interactions: enhanced predation rates and synergistic supression of aphid populations. Ecology 79, 2143-2152.

Matson, P. A., Parton, W. J., Power, A. G. \& Swift, M. J. 1997. Agricultural intensification and ecosystem properties. Science 277, 504-509.

Menalled, F. D., Marino, P. C., Gage, S. H., \& Landis, D. A. 1999 Does agricultural landscape structure affect parasitism and parasitoid diversity? Ecol. Appl. 9, 634-641.

Menalled F. D., Costamagna A. C., Marino P. C. \& Landis, D. A. 2003 Temporal variation in the response of parasitoids to agricultural landscape structure. Agr. Ecosyst. Environ 96, 29-35.

Östman, Ö., Ekbom, B. \& Bengtsson, J. 2001 Farming practice and landscape heterogeneity influence biological control. Basic Appl. Ecol. 2, 365-371.

Palmer, T. N. \& Räisänen J. 2002 Quantifying the risk of extreme seasonal precipitation events in a changing climate. Nature 415, 512-514.

Pickett, S. T. A. \& Cadenasso, M. L., 1995 Landscape ecology: spatial heterogeneity in ecological systems. Science 269, 331-334.

Pimm, S. L. 1991 The balance of nature. The University of Chicago Press, Chicago. 
Powell, W. 1986 Enhancing parasitoid activity in crops. In: Insect parasitoids (eds Waage, J. \& Greathead, W.). Academic Press, London, pp. 319-340.

Raymond, B., Darby, A. C. \& Douglas, A. E. 2000 Intraguild predators and the spatial distribution of a parasitoid. Oecologia 124, 367-372.

Ricketts, T. H. 2001 The matrix matters: Effective isolation in fragmented landscapes. Am. Nat. 158, 87-99.

Riley, J. R., Reynolds, D. R., Mukhopadhyay, S., Ghosh, M. R. \& Sarkar, T. K. 1995 Longdistance migration of aphids and other small insects in northeast India. Eur. J. Entomol. 92, 639-653.

Roland, J. \& Taylor, P. D. 1997 Insect parasitoid species respond to forest structure at different spatial scales. Nature 386, 710-713.

Rosenheim, J. A., Kaya, H. K., Ehler, L. E., Marois, J. J. \& Jaffee, B. A. 1995 Intraguild predation among biological-control agents: theory and evidence. Biol. Control 5, 303335 .

Rosenheim, J. A. 1998 Higher-order predators and the regulation of insect herbivore populations. Ann. Rev. Entomol. 43, 421-447.

Rosenzweig, M. L. 1995 Species diversity in time and space. Cambridge University Press, Cambridge.

Schmidt, M. H., Lauer, A., Purtauf, T., Thies, C., Schaefer, M. \& Tscharntke, T. 2003 Relative importance of predators and parasitoids for cereal aphid control. Proc. R. Soc. Lond. B 270, 1905-1909.

Sigsgaard, L. 2002 A survey of aphids and aphid parasitoids in cereal fields in Denmark, and the parasitoids' role in biological control. J. Appl. Entomol. 126, 101-107.

Sokal, R. R. \& Rohlf, F. J. 1995 Biometry. $3^{\text {rd }}$ Edition. Freeman \& Co., New York.

Snyder, W. E. \& Ives, A. R. 2001 Generalist predators disrupt biological control by a specialist parasitoid. Ecology 82, 705-716.

Stary, P. 1976 Parasite spectrum and relative abundance of parasites of cereal aphids in Czechoslovakia (Hymenoptera, Aphidiidae; Homoptera, Aphidoidea). Acta ent. bohemoslov. 73, 216-223.

Stary, P. 1978 Seasonal relations between lucerne, red clover, wheat and barley agroecosystems through the aphids and parasitoids (Homoptera, Aphididae; Hymenoptera, Aphiddiidae) Acta ent. bohemoslov. 75, 296-311.

Steffan-Dewenter, I., Münzenberg, U. \& Tscharntke, T. 2001 Pollination, seed set, and seed predation on a landscape scale. Proc. R. Soc. Lond. B 268, 1685-1690.

Steffan-Dewenter, I., Münzenberg, U., Bürger, C., Thies, C. \& Tscharntke, T. 2002 Scaledependent effects of landscape structure on three pollinator guilds. Ecology 83, 14211432. 
Sunderland, K. D., Axelsen, J. A., Dromph, K., Freier, B., Hemptinne, J. L., Holst, N. H., Mols, P. J. M., Petersen, M. K., Powell, W., Ruggle, P., Triltsch, H. \& Winder, L. 1997 Pest control by a community of natural enemies. Acta Jutlandica 72, 271-326.

Taylor, L. R. 1977 Migration and spatial dynamics of an aphid, Myzus persicae. J. Anim. Ecol. 46, 411-423.

Tischendorf, L. \& Fahrig, L. 2000 On the usage and measurement of landscape connectivity. Oikos 90, 7-19.

Thies, C., \& Tscharntke, T. 1999 Landscape structure and biological control in agroecosystems. Science 285, 893-895.

Thies, C., Steffan-Dewenter, I. \& Tscharntke, T. 2003 Effects of landscape context on herbivory and parasitism at different spatial scales. Oikos 101, 18-25.

Tilman, D., Cassman, K. G., Matson, P. A., Naylor, R. \& Polaski, S. 2002 Agricultural sustainability and intensive production practices. Nature 418, 671-677.

Tscharntke, T. \& Kruess, A. 1999 Habitat fragmentation and biological control. In: Theoretical approaches to biological control (eds Hawkins, B. A. \& Cornell, H. V.). Cambridge University Press, Cambridge, pp. 190-205.

Tscharntke, T. 2000. Parasitoid populations in the agricultural landscape. In: Parasitoid population biology (eds Hochberg, M. E. \& Ives, A. R.). Princeton University Press, Princeton, pp. 235-253.

Tscharntke, T., Steffan-Dewenter, I., Kruess, A. \& Thies, C. 2002 Contribution of small habitat fragments to conservation of insect communities of grassland-cropland landscapes. Ecol. Appl. 12, 354-363.

Tscharntke, T. \& Brandl, R. 2004 Plant-insect interactions in fragmented landscapes. Ann. Rev. Entomol. 49, 405-430.

Triltsch, H., Gosselke, U., Freier, B. \& Roßberg, D. 1998 Zum Phänomen der schnelleren Entwicklung von Insekten bei Wechseltemperaturen. Mitt. Biol. Bundesanstalt 357, 1239.

Turner, M., Gardner, R. H. \& O’Neill, R. V. 2001 Landscape ecology in theory and practice, Springer, New York.

Van Driesche, R. G. \& Bellows, T. S. (1996). Biological control. Chapman \& Hall, New York.

Van Nouhuys, S. \& Hanski, I. 2002a Multitrophic interactions in space: metacommunity dynamics in fragmented landscapes. In: Multitrophic level interactions (eds Tscharntke, T. \& Hawkins, B. A.). Cambridge University Press, Cambridge, pp. 127-147.

Van Nouhuys, S. \& Hanski, I. 2002b Colonization rates and distances of a host butterfly and two specific parasitoids in a fragmented landscape. J. Anim. Ecol. 71, 639-650.

Van Nouhuys, S. \& Lei, G. C. 2004 Parasitoid-host metapopulation dynamics : the causes and consequences of phenological asynchrony. J. Anim. Ecol. 73, 526-535. 
Wäckers, F.L. 1994 The effect of food deprivation on the innate visual and olfactory preferences in the parasitoid Cotesia rubecula. J. Insect Physiology 40, 641-649.

Wäckers, F. L. \& Steppuhn, A. 2003 Characterizing nutritional state and food sources use of parasitoids collected in fields with high and low nectar availability. IOBC wprs Bulletin 26, 209-214.

Wäckers, F. L. \& Swaans, C. P. M. 1993. Finding floral nectar and honeydew in Cotesia rubecula: random or direct? Proc. Exp. Appl. Entomol. 4, 67-72.

Wiens, J. A., Stenseth, N. C., van Horne, B. \& Ims, R. A. 1993 Ecological mechanisms and landscape ecology. Oikos 66, 369-380.

Wiens J. A., Schooley, R. L. \& Weeks, R. D. 1997 Patchy landscapes and animal movements: do beetles percolate? Oikos 78, 257-264.

Wratten, S. D. \& Powell, W. 1991 Cereal aphids and their natural enemies. In: The ecology of temperate cereal fields (eds Firbank, I. G., Carter, N., Darbyshire, J. F. \& Potts, G. R.). Blackwell Scientific, Oxford, pp. 233-257.

Wratten, S. D. \& van Emden, H. F. 1995 Habitat management for enhanced activity of natural enemies of insect pests. In: Ecology and integrated farming systems (eds Glen, D. M., Greaves, M.P. \& Anderson, H.M.). Wiley \& Sons, Chichester, pp. 117-145. 


\section{Chapter 7}

\section{The influence of landscape context and farming practices on parasitism of cereal aphids}

Indra Roschewitz, Melanie Hücker, Teja Tscharntke \& Carsten Thies

Agriculture, Ecosystems and Environment, in press

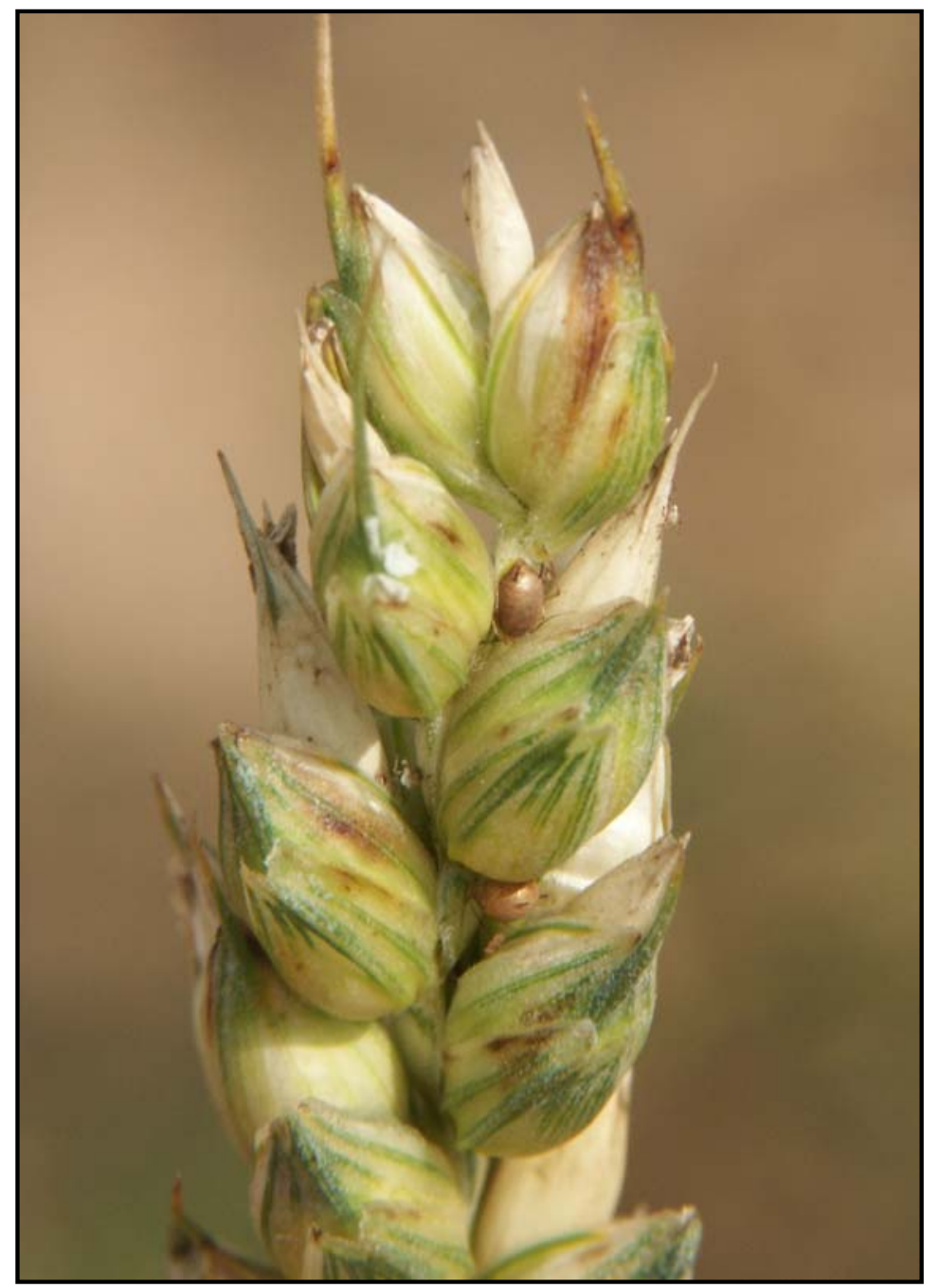




\begin{abstract}
Agri-environmental schemes in Europe aim to support biodiversity and ecological functions in agroecosystems, which are related to both farming practices and landscape context. Here, we analysed the relative importance of farming practices and landscape context on an important ecosystem service, the naturally occurring biological pest control. In a 3-years study, we investigated cereal aphids and their mortality due to parasitism in 24 paired winter wheat fields (i.e., one organic and one conventional field close to each other). The field pairs were located in 12 landscapes differing in landscape complexity, simple landscapes with high percentage of arable land ( $\sim 80 \%)$, and complex landscapes with lower percentage of arable land $(\sim 50 \%)$ and high proportions of semi-natural habitats. Arable land (\%) was used as simple predictor of landscape complexity, as it was closely related with other landscape metrics like habitat-type diversity. Aphid population densities varied considerably between the 3 years and the 12 different landscapes. Organic farming was related to lower abundance of cereal aphids at the time of wheat flowering, but not to higher parasitism. At wheat ripening, complex landscapes were related to higher parasitism than simple landscapes, presumably due to more overwintering sites, alternative hosts and nectar sources for parasitoids. However, aphid population densities were also higher in complex landscapes, presumably due to the high availability of winter hosts for these host-alternating species. In a geographical scale analysis, we tested the relative importance of landscape complexity at 5 spatial scales (1-3 km radius around the study sites). Parasitoids responded to landscape complexity at spatial scales of 1 to $2 \mathrm{~km}$, whereas aphid densities responded to landscape complexity at all spatial scales, indicating a trophic level-specific perception of the surrounding landscape. We conclude that complex landscapes with low percentage of arable land appeared to enhance parasitism, but also the host-alternating aphids, so overall effects of landscape complexity on cereal aphid control appear to be ambivalent.
\end{abstract}

\title{
Key words
}

Farming practices; conventional farming; organic farming; landscape complexity; cereal aphids; aphid parasitoids; biological control; spatial scale. 


\section{Introduction}

Agriculture is multifunctional, it provides food, water and other biological goods, and influences the environment, biological diversity, recreation value, and landscape aesthetics (Gurr et al., 2003). Increasing intensity of agricultural practices in the last decades caused environmental problems such as water contamination, soil degradation, and biodiversity losses (Matson et al., 1997; Krebs et al., 1999; Tilman et al., 2002). Organic and low-intensity farming systems are reported to produce food in a more sustainable way than conventional farming (Reganold et al., 2001), are financially supported by the EU via agri-environmental schemes (Council Regulation, 1992, 1999), and may contribute to the conservation of biodiversity (Dritschilo and Erwin, 1982; Kromp, 1989; Moreby et al., 1994; Paoletti, 1995; The Soil Association, 2000; Hyvönen et al., 2003). In contrast, other recent studies found similar or even higher numbers of species in conventional than in organic and low-intensity farming systems, respectively (Weibull et al. 2000, 2003; Kleijn et al., 2001; Melnychuk et al., 2003).

Intensive agriculture does not only lead to ecological problems on the local field scale, but also on the landscape level. Former heterogeneous, complex landscapes with well-balanced proportions of arable land, grassland, forests, fallows, hedgerows and other (semi-)natural habitats are often transformed to homogeneous, simple landscapes with high proportions of arable land. These large-scale changes of landscape context are related to the local loss of diversity and ecological functioning (Kareiva, 1990; Turner and Gardner, 1991; Pickett and Cadenasso, 1995; Polis et al., 1997; Roland and Taylor, 1997; Menalled et al., 1999; Thies and Tscharntke, 1999; Tischendorf and Fahrig, 2000; Thies et al., 2003). For example, parasitism of the rape pollen beetle (Meligethes aeneus F.), an important pest of oilseed rape (Brassica napus L.), decreases in simple landscapes, causing higher crop damage in simple than complex landscapes (Thies and Tscharntke, 1999).

Relatively little is known on the contribution of organic farming to the functioning of ecosystem services such as biological control of plant pests. Letourneau and Goldstein (2001) found higher natural enemy abundance in organic than in conventional tomato (Lycopersicon esculentum Mill.) fields in California, whereas herbivore abundance did not differ between the farming systems. Studies investigating the relative importance of (local) effects of farming practices and (regional) effects of landscape context are rare. Weibull et al. (2003) and Weibull and Östman (2003) analysed these effects on species richness and species composition, and Östman et al. (2001a) on the condition of polyphagous carabid beetles (Coleoptera, Carabidae). Östman et al. (2001b) found that carabid beetles had a greater negative impact on cereal aphid (Homoptera, Aphidiidae) establishment in organic than in conventional farms, and in complex than in simple landscapes. After aphid establishment, population growth did not differ between the farming systems, but was greater in simple landscapes. 
In this study, we simultaneously analysed the effects of farming practices (organically vs. conventionally managed) and landscape complexity (complex vs. simple) on the abundance and parasitism of cereal aphids, which are economically important pests on wheat (Triticum aestivum L.). In a 3-year study, we analysed 72 wheat fields ( 24 per year), which were located in 12 agricultural landscapes of southern Lower Saxony (Germany) differing in landscape complexity. By comparing farms with similar landscape features but different farming systems, we were able to quantify the relative importance of local and landscape effects. We hypothesised that aphid abundance should be lower (1) in organic than in convention fields, and (2) in complex than in simple landscapes, due to a better functioning of biological pest control.

\section{Material and methods}

Study area

The study was conducted in the years 2001 to 2003 in 12 agricultural landscapes around the city of Göttingen (North Germany). This area covers approx. $1350 \mathrm{~km}^{2}$ and is dominated by agricultural land use, i.e., arable land-grassland mosaics covering about $75 \%$ of the region, while the remaining area is characterised by patchily distributed fragments of natural and semi-natural habitats such as grasslands, forests, fallows, and hedgerows. We selected 12 circular landscape sectors with a radius of $3 \mathrm{~km}$ in either simple landscapes with high percentage of annual crop fields $(\sim 80 \%)$ or complex landscapes with a low percentage of arable land $(\sim 50 \%)$ and with larger areas of noncrop habitats. The distribution of the landscape sectors did not show any north-south or east-west gradient to avoid possible problems such as correlations between landscape complexity and abiotic factors, e.g. microclimate and soil fertility. In the centre of each landscape sector, we selected one organically and one conventionally managed winter wheat field located close to each other as study sites. Due to crop rotation, the fields differed between the years, but in each year, they were located close to those of the other years. The mean field size was $3.5 \pm 1.7$ ha (arithmetic mean \pm standard deviation), and did neither differ between the landscapes nor between the farming systems (one-way analyses of variance, $\mathrm{F}=0.01, \mathrm{P}=0.94$, and $\mathrm{F}=1.04, \mathrm{P}=0.32$, respectively).

\section{Sampling of insects}

Population dynamics of the cereal aphids Sitobion avenae F., Metopolophium dirhodum Walk., and Rhopalosiphum padi L. and of parasitic wasps (Hymenoptera: Ichneumonoidea, Chalcidoidea), which are an important group of natural enemies in our region (Schmidt et al., 2003), were sampled in one $700 \mathrm{~m}^{2}$ plot $(20 \mathrm{~m} * 35 \mathrm{~m})$ in each winter wheat field. The sampled field section included a field edge $(20 \mathrm{~m}$ ) as well as the field centre (up to $35 \mathrm{~m}$ apart 
from the field edge). Perennial, grassy field margins were adjacent to the field edge in all landscapes. The plots in the conventional fields were not sprayed with insecticides.

Insects were sampled twice a year, first at wheat flowering (2001: June $19^{\text {th }}$ to $22^{\text {nd }} ; 2002$ : June $8^{\text {th }}$ to $11^{\text {th }} ; 2003$ : June $17^{\text {th }}$ to $\left.20^{\text {th }}\right)$ and second at wheat ripening $\left(2001\right.$ : July $10^{\text {th }}$ to $13^{\text {th }}$; 2002: July $3^{\text {rd }}$ to $6^{\text {th }} ; 2003$ : July $2^{\text {nd }}$ to $5^{\text {th }}$ ). As one sampling campaign lasted four days, the 12 field pairs were sampled at random order to prevent a bias of data due to the phenological stage of wheat. The mean temperature $\left({ }^{\circ} \mathrm{C}\right)$ and total rain fall $(\mathrm{mm})$ during the study periods from June to July were $13.9^{\circ} \mathrm{C}$ and $59.9 \mathrm{~mm}$ in June $2001,16.6^{\circ} \mathrm{C}$ and $71.4 \mathrm{~mm}$ in June 2002, $18.1^{\circ} \mathrm{C}$ and $47.7 \mathrm{~mm}$ in June $2003,18.4^{\circ} \mathrm{C}$ and $68.8 \mathrm{~mm}$ in July $2001,17.3^{\circ} \mathrm{C}$ and $95.2 \mathrm{~mm}$ in July 2002 , and $18.7^{\circ} \mathrm{C}$ and $46.9 \mathrm{~mm}$ in July 2003 (data from the meteorological station in Göttingen).

Aphids were counted and identified to species on $100(4 * 25)$ wheat shoots per field along four $15 \mathrm{~m}$-transects parallel to the field edge. The first transect was located at the field edge $(0$ $\mathrm{m}-1 \mathrm{~m}$ apart from the first drill row), and the second also in the edge area (3 $\mathrm{m}-4 \mathrm{~m}$ apart from the first drill row). The third and fourth transect were situated in the field centre (approx. $29 \mathrm{~m}-30 \mathrm{~m}$ and $32 \mathrm{~m}-33 \mathrm{~m}$ apart from the first drill row). Within a transect, 25 wheat shoots were sampled ( 5 randomly chosen shoots every $3 \mathrm{~m}$ ). Mortality due to parasitism was quantified by counting aphid mummies on the same 100 wheat shoots. Thereby all mummies (unhatched and also already hatched) were included to prevent possible underestimation of parasitism, as parasitised but not yet mummified aphids were not included in this sampling method. All mummies were collected and brought to the laboratory, where the parasitoids were determined to genus level after they hatched.

\section{Analysis of landscape complexity}

Landscape complexity was measured around each study site at 5 spatial scales (i.e., circular landscape sectors of $1 \mathrm{~km}, 1.5 \mathrm{~km}, 2 \mathrm{~km}, 2.5 \mathrm{~km}$, and $3 \mathrm{~km}$ radius). Official digital thematic maps (ATKIS - Digitales Landschaftsmodell 25/1; Landesvermessung und Geobasisinformation, Hannover, Germany, 1991-1996) and the Geographical Information System ArcView 3.1 (ESRI Geoinformatik GmbH, Hannover, Germany) were used to measure the area of arable land, perennial grassland, forests, hedgerows, garden land, and settlement in each of the sectors. The percentage of arable land per landscape was considered as a simple indicator for landscape complexity, because of its close relation with other landscape metrics such as the diversity of land-use types after Shannon-Wiener ( $F=105.33 ; \mathrm{p}$ $<0.001 ; \mathrm{R}=-0.78 ; \mathrm{n}=70$ landscape sectors of $1.5 \mathrm{~km}$ radius) and the perimeter-to-area ratio $(\mathrm{F}=53.74 ; \mathrm{p}<0.001 ; \mathrm{R}=-0.66 ; \mathrm{n}=70$ landscape sectors of $1.5 \mathrm{~km}$ radius $)$. For statistical analyses, we divided the study sites into two landscape complexity groups for each of the five radii of landscape sectors, a complex landscape group (i.e., $<65 \%$ arable land) and a simple landscape group (i.e., $>65 \%$ arable land). 


\section{Statistical analysis}

Three-way analyses of covariance (ANCOVA) were used to simultaneously analyse the effects of farming system (organic vs. conventional), landscape complexity (complex vs. simple), and study year (2001; 2002; 2003) on aphid abundance (aphids/100 wheat shoots) and mortality due to parasitism (parasitism rate $(\%)=$ mummies $/($ aphids + mummies) $* 100)$. Analyses were conduced for all aphid or all parasitoid species together, respectively, as data on single species were sparse and therefore not suitable for statistical analyses. As host plant density (wheat shoots $/ \mathrm{m}^{2}$ ) and host density (aphids/100 wheat shoots) might be expected to be of importance for aphid abundance and parasitism, we selected these parameters as covariates in the ANCOVA. Interactions between all these variables were tested, but they were not significant and therefore not mentioned in the results section. Basically, we analysed 72 study sites (3 years, 2 farming systems, 12 landscapes), but landscape data were only available for 70 fields, and data on host plant density for only 68 fields. In a first step, we analysed the effects of landscape complexity at a distinct spatial scale of $1.5 \mathrm{~km}$ radius, following former experience (Thies and Tscharntke, 1999). In a second step, we tested these effects at different spatial scales $(1 \mathrm{~km}, 1.5 \mathrm{~km}, 2 \mathrm{~km}, 2.5 \mathrm{~km}$, and $3 \mathrm{~km}$ radius). Logarithmic transformation of the variables was used to achieve normality of the residuals from the statistic models and arcsine-square-root transformation of $\mathrm{p}$ for the proportions (Sokal and Rohlf, 1995). In the text and tables, arithmetic means \pm standard deviations (SD) are given.

\section{Results}

In total, we found 17069 individuals of cereal aphids in the wheat fields, whereof 553 were mummified due to parasitism. The grain aphid Sitobion avenae was the most abundant $(72.7 \pm$ $25.7 \%$ of all aphid individuals, $\mathrm{n}=72$ wheat fields), whereas Metopolophium dirhodum appeared in lower densities $(25.2 \pm 25.7 \%$ of all aphid individuals, $\mathrm{n}=72$ wheat fields $)$ and Rhopalosiphum padi occurred only sporadically $(2.1 \pm 3.9 \%$ of all aphid individuals, $\mathrm{n}=72$ wheat fields). 425 (76.9\%) of the mummified aphids were S. avenae, and $128(23.1 \%) \mathrm{M}$. dirhodum, whereas $R$. padi was not parasitised. 319 of the 553 aphid mummies $(57.7 \%)$ hatched in the laboratory and could be determined to genus level, whereas $24.6 \%$ already hatched in the fields and $17.7 \%$ did not hatch. $67.6 \%$ of the identified parasitoids were primary parasitoids of five different genera: Aphidius (39.4\%), Praon (11.2\%), Ephedrus (9.8 \%), Aphelinus (7.1\%), and Toxares (0.1\%). $32.4 \%$ of the mummies were hyperparasitised by six genera, including Alloxysta (13.0\%), Asaphes (8.1\%), Dendrocerus (5.9 \%), Coruna (3.8\%), Phaenoglyphis (1.5\%), and Diaeretiella (0.1\%). The hyperparasitism rate did neither differ between sampling dates (one-way analysis of variance: $F=2.32 ; p=0.13)$ nor between years $(F=0.18 ; p=0.84)$. Population densities of aphids and 
parasitism rates (at wheat flowering and at wheat ripening) varied considerably between the 3 study years as well as between the 24 study sites per year (Table 1).

Table 1. Aphid abundance on 100 wheat shoots and parasitism rates at the time of wheat flowering and wheat ripening.

\begin{tabular}{lccc}
\hline & Mean \pm SD & Minimum & Maximum \\
\hline Aphids/100 wheat shoots & & & \\
- Wheat flowering: & & & \\
2001 & $30.29 \pm 27.74$ & 7.00 & 99.00 \\
2002 & $20.63 \pm 18.57$ & 0.00 & 73.00 \\
2003 & $107.67 \pm 68.50$ & 7.00 & 229.00 \\
- Wheat ripening: & & & \\
2001 & $36.63 \pm 26.55$ & 7.00 & 135.00 \\
2002 & $52.58 \pm 63.47$ & 12.00 & 308.00 \\
2003 & $463.42 \pm 322.32$ & 124.00 & 1447.00 \\
Parasitism rates (\%) & & & \\
- Wheat flowering: & & & \\
2001 & & & \\
2002 & $3.22 \pm 4.17$ & 0.00 & \\
2003 & $0.67 \pm 2.22$ & 0.00 & 9.09 \\
- Wheat ripening: & $0.23 \pm 0.69$ & 0.00 & 2.90 \\
2001 & & & \\
2002 & & 6.00 & 71.43 \\
2003 & $1.26 \pm 1.18 \%$ & 0.00 & 56.25 \\
\hline
\end{tabular}

Note: Means \pm SD, minima, and maxima are given for 72 winter wheat fields.

In a first step, the influence of farming system and landscape complexity on aphid abundance and parasitism was analysed on a spatial scale of $1.5 \mathrm{~km}$ radius of landscape sectors. At wheat flowering, aphid abundance was affected by year and farming system (Table 2). In the year 2003, aphids colonised the fields in higher densities than in the years 2001 and 2002. Their abundance was generally higher in conventional than in organic fields, but we could not detect any differences between complex and simple landscapes (Fig. 1A-C). At wheat ripening, aphid densities again differed between years, but were also affected by landscape complexity (Table 2). We found more aphids in 2003 than in 2001 and 2002, and more aphids in complex than in simple landscapes, but no significant differences between conventional and organic fields (Fig. 1D-F). 
Table 2. Aphid abundance on 100 wheat shoots at the time of wheat flowering and wheat ripening: differences between study years $(2001 ; 2002 ; 2003)$, farming systems (organic vs. conventional), and landscapes of different complexity (complex vs. simple) at 5 different spatial scales.

\begin{tabular}{|c|c|c|c|c|c|}
\hline & \multicolumn{4}{|c|}{ Spatial scale (radius) } & \multirow[b]{2}{*}{$3 \mathrm{~km}$} \\
\hline & $1 \mathrm{~km}$ & $1.5 \mathrm{~km}$ & $2 \mathrm{~km}$ & $2.5 \mathrm{~km}$ & \\
\hline \multicolumn{6}{|l|}{ Wheat flowering: } \\
\hline - Study year & $22.67^{* * *}$ & $22.71^{* * *}$ & $22.22^{* * *}$ & $22.21^{* * *}$ & $22.19^{* * *}$ \\
\hline - Farming system & $10.68^{* *}$ & $10.55^{\star *}$ & $11.29^{* *}$ & $12.12^{* \star *}$ & $12.33^{* * *}$ \\
\hline - Landscape complexity & 0.73 n.s. & 1.45 n.s. & 1.05 n.s. & 0.25 n.s. & 0.03 n.s. \\
\hline - Host plant density (covariate) & $4.28^{*}$ & 3.93 n.s. & $4.37^{*}$ & $5.20^{*}$ & $5.56^{*}$ \\
\hline \multicolumn{6}{|l|}{ Wheat ripening: } \\
\hline - Study year & $104.93^{* * *}$ & $104.45^{\star * *}$ & $101.60^{* \star *}$ & $104.25^{\star \star \star}$ & $105.36^{\star \star *}$ \\
\hline - Farming system & 2.03 n.s. & 2.12 n.s. & 2.56 n.s. & 2.94 n.s. & 2.82 n.s. \\
\hline - Landscape complexity & $4.39^{\star}$ & $5.09^{*}$ & $4.41^{*}$ & $4.26^{*}$ & $4.52^{\star}$ \\
\hline - Host plant density (covariate) & 2.84 n.s. & 2.76 n.s. & 3.23 n.s. & 3.80 n.s. & 3.86 n.s. \\
\hline \multicolumn{6}{|c|}{$\begin{array}{l}\text { Note: F-values and levels of significance from ANCOVA are shown for all factors, including the covariate host } \\
\left.\text { plant density (wheat shoots } / \mathrm{m}^{2}\right), \mathrm{n}=68 \text { winter wheat fields. }\end{array}$} \\
\hline \multicolumn{6}{|c|}{$\begin{array}{l}\text { Parasitism rates were generally low at the time of wheat flowering. They were higher in } 2001 \\
\text { than in } 2002 \text { and } 2003 \text {, and did not change with farming system or landscape complexity } \\
\text { (Table } 3 \text {, Fig. } 2 \mathrm{~A}-\mathrm{C} \text { ). At wheat ripening, parasitism did not differ between the study years and } \\
\text { the farming systems, but changed with landscape context (Table } 3 \text { ). Parasitism rates were } \\
\text { higher in complex than in simple landscapes (Fig. 2D-F). Host density (as covariate), which } \\
\text { was negatively related with parasitism rates, was the best predictor for the variability of aphid } \\
\text { mortality due to parasitism (Table } 3 \text {, Fig. } 3 \text { ). }\end{array}$} \\
\hline
\end{tabular}



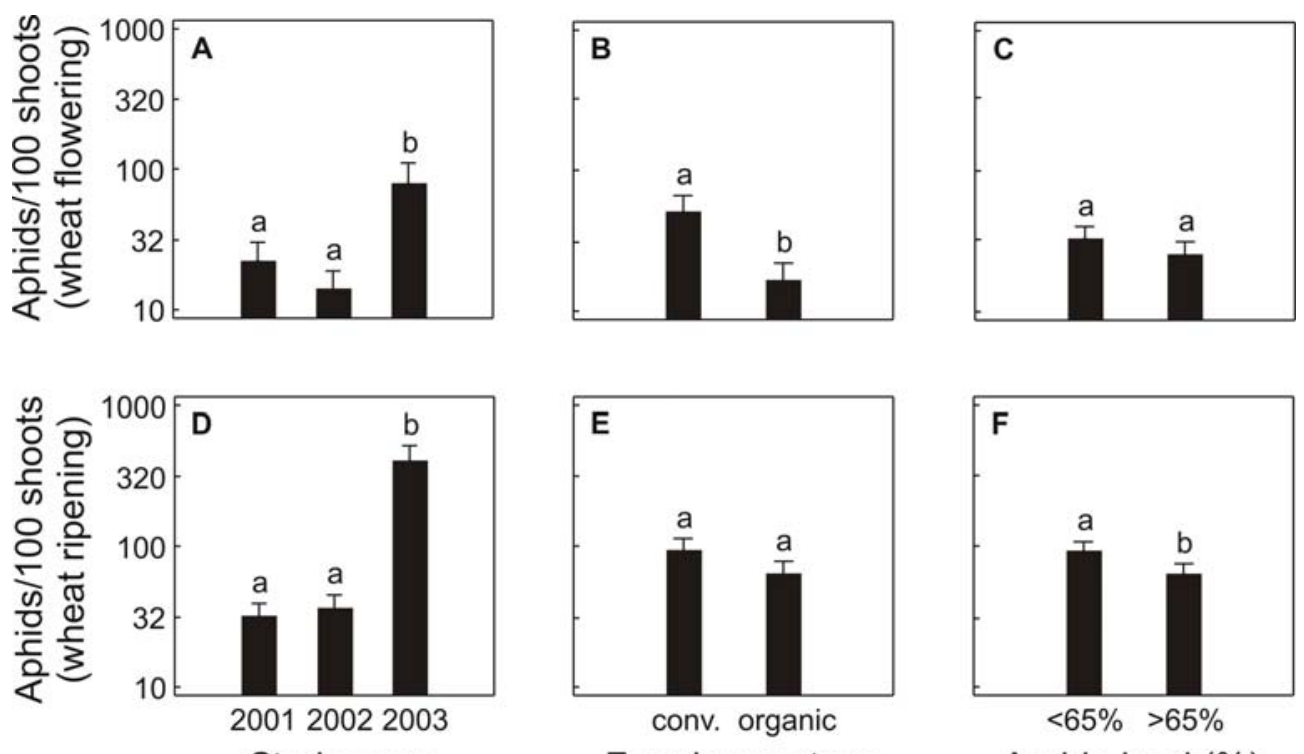

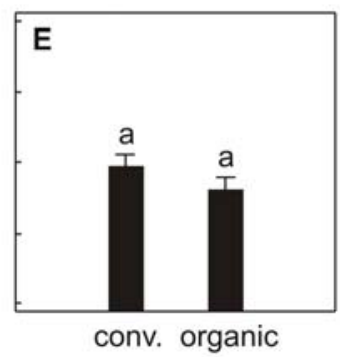

Farming system

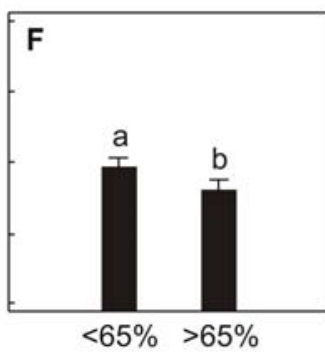

Arable land (\%)

Figure 1. Differences in aphid abundance at wheat flowering depending on A) the study year $(2001 ; 2002 ; 2003)$, B) the farming system (conventional vs. organic), and C) landscape complexity ( $<65 \%$ arable land $=$ complex vs. $>65 \%$ arable land $=$ simple), as well as differences in aphid abundance at wheat ripening depending on $\mathrm{D})$ the study year $(2001 ; 2002 ; 2003)$, E) the farming system (conventional vs. organic), and F) landscape complexity $(<65 \%$ arable land $=$ complex vs. $>65 \%$ arable land $=$ simple $)$. Arithmetic means $\pm 95 \%$ Scheffe intervals; $n=$ 68 winter wheat fields.
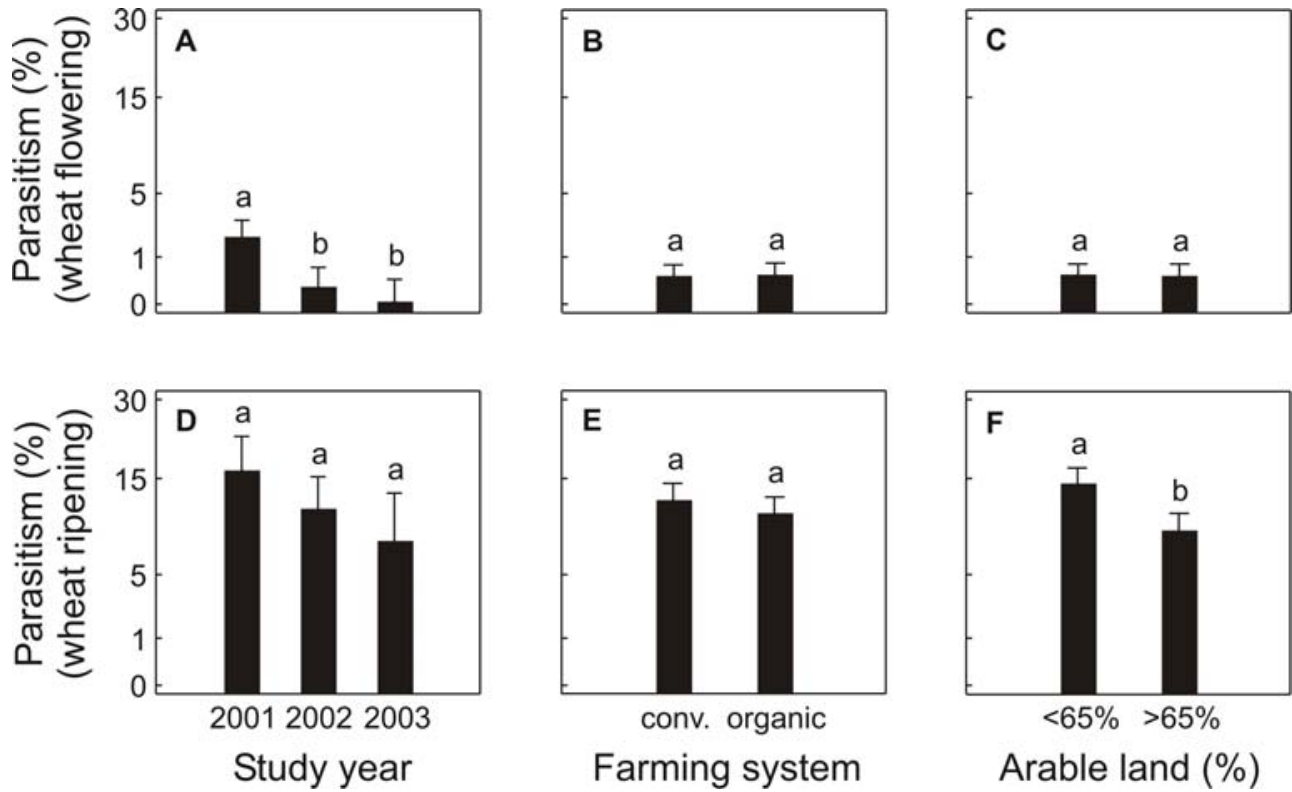

Figure 2. Differences in parasitism rates at wheat flowering depending on A) the study year (2001;2002; 2003), B) the farming system (conventional vs. organic), and C) landscape complexity ( $<65 \%$ arable land $=$ complex vs. $>65 \%$ arable land $=$ simple), as well as differences in parasitism rates at wheat ripening depending on $\mathrm{D})$ the study year $(2001 ; 2002 ; 2003)$, E) the farming system (conventional vs. organic), and F) landscape complexity $(<65 \%$ arable land $=$ complex vs. $>65 \%$ arable land $=$ simple $)$. Arithmetic means $\pm 95 \%$ Scheffe intervals; $n=$ 70 winter wheat fields. 
In a second step, we analysed the relative importance of factors at different spatial scales (1.0 $\mathrm{km}, 2.0 \mathrm{~km}, 2.5 \mathrm{~km}$, and $3.0 \mathrm{~km}$ radius). At wheat flowering, the relation of landscape complexity to aphid abundance (Table 2) and parasitism (Table 3 ) did not change with spatial scale. At wheat ripening, the higher aphid abundance in complex landscapes could be found at all spatial scales (Table 2). In contrast, parasitoids responded positively to landscape heterogeneity only at 1 to $2 \mathrm{~km}$ radius of landscape sectors, but not at 2.5 to $3 \mathrm{~km}$, indicating scale-dependent effects of landscape complexity in the parasitoids (Table 3).

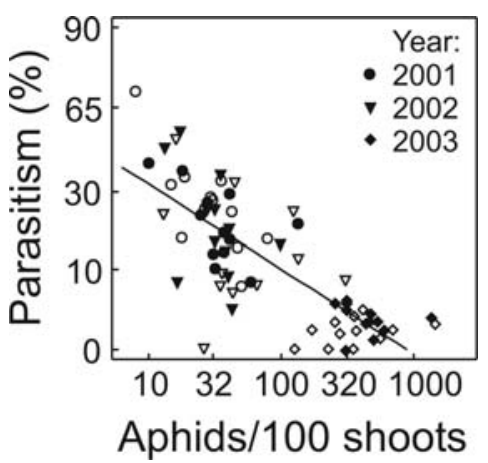

Figure 3. Aphid parasitism rates in dependence of host density (number of aphids/100 wheat shoots) at wheat ripening for the three study years. $\mathrm{Y}=62.0-21.0 \mathrm{X} ; \mathrm{F}=108.3 ; \mathrm{p}<0.0001 ; \mathrm{R}^{2}=60.7 \% ; \mathrm{n}=72$ winter wheat fields. Black symbols $=$ conventional fields, white symbols $=$ organic fields.

Table 3. Aphid parasitism rates at the time of wheat flowering and wheat ripening: differences between study years $(2001 ; 2002 ; 2003)$, farming systems (organic vs. conventional), and landscapes of different complexity (complex vs. simple) at 5 different spatial scales.

\begin{tabular}{|c|c|c|c|c|c|}
\hline & \multicolumn{4}{|c|}{ Spatial scale (radius) } & \multirow[b]{2}{*}{$3 \mathrm{~km}$} \\
\hline & $1 \mathrm{~km}$ & $1.5 \mathrm{~km}$ & $2 \mathrm{~km}$ & $2.5 \mathrm{~km}$ & \\
\hline \multicolumn{6}{|l|}{ Wheat flowering: } \\
\hline - Study year & $9.40^{\star * *}$ & $9.39^{* * *}$ & $9.38^{* * *}$ & $9.66^{* * *}$ & $9.95^{\star \star *}$ \\
\hline - Farming system & 0.01 n.s. & 0.01 n.s. & 0.01 n.s. & 0.04 n.s. & 0.03 n.s. \\
\hline - Landscape complexity & 0.02 n.s. & 0.00 n.s. & 0.00 n.s. & 0.54 n.s. & 1.15 n.s. \\
\hline - Host density (covariate) & 0.82 n.s. & 0.83 n.s. & 0.85 n.s. & 1.05 n.s. & 1.03 n.s. \\
\hline \multicolumn{6}{|l|}{ Wheat ripening: } \\
\hline - Study year & 2.28 n.s. & 2.29 n.s. & 2.47 n.s. & 2.01 n.s. & 1.97 n.s. \\
\hline - Farming system & 0.53 n.s. & 0.64 n.s. & 0.73 n.s. & 0.67 n.s. & 0.56 n.s. \\
\hline - Landscape complexity & $5.94^{*}$ & $6.06^{*}$ & $4.92^{*}$ & 2.81 n.s. & 1.94 n.s. \\
\hline - Host density (covariate) & $17.33^{* * *}$ & $17.60^{* * *}$ & $16.52^{* * *}$ & $14.72^{* * *}$ & $13.93^{* * *}$ \\
\hline
\end{tabular}




\section{Discussion}

In this 3-year study, we analysed the relative importance of farming practices and landscape complexity on cereal aphid-parasitoid interactions in wheat fields. We further tested whether cereal aphids and their parasitoids were affected by the surrounding landscape at different spatial scales. Aphids and parasitoids showed a huge inter-annual variation in abundance and mortality due to parasitism, but were only little affected by farming practices. Although aphid densities at wheat flowering were higher in conventional than in organic fields, this difference did not appear at wheat ripening. Parasitism was generally not affected by farming practices. High aphid parasitism could only be found in complex landscapes with relatively little area of annual crop fields. Non-crop area appeared to support large parasitoid populations, but aphids also profited from complex landscapes, thereby counterbalancing possible control by parasitism. In general, parasitism rate greatly decreased with host density, but in complex landscapes high parasitism rates paralleled high aphid densities, emphasising the role of complex landscapes in the enhancement of parasitoid populations.

\section{Scale-dependent effects of landscape complexity}

Both aphid populations and their parasitoids may have profited from the higher availability of perennial habitats in complex landscapes as they provide overwintering sites as well as alternative host plants and hosts, respectively. Elliott et al. (1998) also found positive effects of complex landscapes on the abundance of aphid predators (four species of lady beetles (Coleoptera, Coccinellidae), the common lacewing (Chrysoperla plorabunda Fitch) and the common damsel bug (Nabis americoferus Carayon)) in wheat, but they did not relate aphid abundance to landscape context. Östman et al. (2001b) showed that aphid colonisation was negatively affected in complex landscapes due to the presence of ground-living predators, but this effect changed over the course of aphid population development, so predation rates became higher in simple landscapes during aphid population growth. The cereal aphids $M$. dirhodum and R. padi are host alternating on Rosa spp. and Prunus padus L., respectively, which are common plant species in our complex landscapes. S. avenae hibernates on perennial grasses (Leather, 1993). Hence, undisturbed perennial areas may support both large aphid and parasitoid populations, whereas high percentage of arable land should disadvantage both groups. Overwintering sites for parasitoids adjacent to crop fields are known to increase egg parasitism of grape leafhoppers (Erythroneura elegantula Osborn) (Corbett and Rosenheim, 1996) and larval parasitism of the rape pollen beetle (Thies and Tscharntke, 1999). Furthermore, complex landscapes provide more nectar sources for adult parasitoids due to a larger cover of flowering plants (Steffan-Dewenter et al., 2001). Powell (1986) and Wratten and Van Emden (1995) give examples of enhanced parasitism due to augmented nectar sources. 
Aphid parasitoids revealed scale-dependent responses to landscape complexity. The predictive power of landscape complexity for parasitism was highest within small landscape sectors of 1 to $2 \mathrm{~km}$ radius, and distinctly decreased as scale increased from small to large radii. This supports the view that parasitoids often show dispersal limitation (Kruess and Tscharntke, 1994, 2000; Tscharntke and Kruess, 1999; With et al., 1999). This may be related to the relatively small body size of aphid parasitoids, as body size is positively related to the organisms' dispersal ability (Roland and Taylor, 1997; Ritchie and Olff, 1999). Thies et al. (2003) found similar scale dependencies ( $1.5 \mathrm{~km}$ radius) for the parasitoids of the rape pollen beetle. In contrast, the aphids were affected by landscape complexity at all analysed spatial scales similarly, suggesting that they were not limited by dispersal ability. This may partly be due to long-distance migration. Several studies suggested that aphids are able to passively fly with the wind over great distances (up to several hundred kilometers, e.g. Taylor, 1977; Halbert et al., 1990; Riley et al., 1995).

Aphid densities were noticeably high in the year 2003, which might be due to weather conditions. Cereal aphid populations are expected to profit from higher temperatures and to suffer from rain fall (Triltsch et al., 1998; Gosselke et al., 2001). In accordance with these findings, our results showed that the high aphid densities were related to higher average temperatures and lower rain falls in 2003 (compared to 2001 and 2002).

\section{Organic vs. conventional farming}

The expectation that cereal aphid abundance should be lower in organic than in conventional fields due to better functioning of biological control was not confirmed in our study. Although there is evidence that organic farming practices enhance the diversity of several arthropod groups (Dritschilo and Erwin, 1982; Kromp, 1989; Paoletti, 1995; Moreby et al., 1994; Letourneau and Goldstein, 2001), parasitism was not higher in organic than conventional fields. Particularly, the higher density and diversity of arable weeds in organic fields (Hald, 1999; Menalled et al., 2001; Hyvönen et al., 2003; also in this study: Roschewitz et al., unpubl.) could be expected to nourish adult parasitoids (Wäckers and Swaans, 1993; Wäckers, 1994; Steppuhn and Wäckers, 2002) as these plants provide nectar sources. Aphid densities were higher in conventional than in organic fields only at wheat flowering stage, a result similar to the findings of Östman et al. (2001b). This may be related to a better food supply due to the use of fast soluble mineral nitrogen fertilizers. At wheat flowering, aphids concentrate to suck on the wheat shoots and leaves, but during the wheat ripening period aphids migrate to the wheat ears, where differences in nutrient contents between organic and conventional plants may not be that great as in the other plant components (Honek, 1991a). This suggestion is supported by Honek (1991b), Hasken and Poehling (1995), and Duffield et al. (1997), showing the leaf-colonising species $M$. dirhodum to be positively influenced by high nitrogen applications while the ear-colonising species $S$. avenae was not or even positively affected by lower plant quality. The similar aphid densities in the two farming 
systems at wheat ripening, despite different starting points at wheat flowering, suggest that local augmentation of aphids from wheat flowering to wheat ripening is not only a function of within-field factors (food quality). The surrounding landscape presumably superposed the within-field reproduction process due to a continuous colonisation of the fields from the surrounding perennial habitats.

\section{Conclusion}

In conclusion, high rates of parasitism were only found in complex landscapes with large areas of perennial habitats, but such landscapes also enhanced aphid populations. In contrast to expectations, farming system did not appear to be important for parasitism. Future field experiments may take more groups of natural enemies into account to better understand ecological processes such as biological control in dependence of local and regional management (Gaston and Lawton, 1990; Ricklefs and Schluter, 1993; Whittaker et al., 2001). Agri-environmental schemes should consider both the land-use intensity within the field and the structure of the surrounding landscape, which can be enriched by farmers with the conversion of arable land into perennial habitats. We also have to consider that parasitoids and their hosts perceive their environment at different spatial scales, so landscape management has a species-specific or trophic level-specific component.

\section{Acknowledgements}

We thank the farmers who allowed us to work in their fields, Doreen Gabriel and Christof Bürger for assistance during GIS-analyses, Uli Thewes for help with field work, two anonymous reviewers for helpful comments on the manuscript, and the German Science Foundation (DFG) for financial support.

\section{References}

Corbett, A., Rosenheim, J.A., 1996. Impact of natural enemy overwintering refuge and its interaction with the surrounding landscape. Ecol. Entomol. 21, 155-164.

Council Regulation, 1992. Council Regulation (EEC) 2078/92 of June 30, 1992 on agricultural production methods compatible with the requirements of the protection of the environment and the maintenance of the countryside. Off. J. Eur. Communities L215, 85-90.

Council Regulation, 1999. Council Regulation (EC) 1257/1999 of May 17, 1999 on support for rural development from the European Agricultural Guidance and Guarantee Fund 
(EAGGF) and amending and repealing certain regulations (June 26, 1999). Off. J. L160, 80-101.

Dritschilo, W., Erwin, T.L., 1982. Responses in abundance and diversity of cornfield carabid communities to differences in farm practices. Ecology 63, 900-904.

Duffield, S.J., Bryson, R.J., Young, J.E.B., Sylvester Bradley, R., Scott, R.K., 1997. The influence of nitrogen fertilizer on the population development of the cereal aphids Sitobion avenae (F.) and Metopolophium dirhodum (Wlk.) on field grown winter wheat. Ann. Appl. Biol. 130, 13-26.

Elliott, N.C., Kieckhefer, R.W., Lee, J.H., French, B.W., 1998. Influence of within-field and landscape factors on aphid predator populations in wheat. Landscape Ecol. 14, 239-252.

Gaston, K.J., Lawton, J.H., 1990. Effects of scale and habitat on the relationship between regional distribution and local abundance. Oikos 58, 329-335.

Gosselke, U., Triltsch, H., Roßberg, D., Freier, B., 2001. GETLAUS01 - the latest version of a model simulating aphid population dynamics in dependence on antagonists in wheat. Ecol. Model. 145, 143-157.

Gurr, G.M., Wratten, S.D., Luna, J.M., 2003. Multi-function agricultural biodiversity: pest management and other benefits. Basic Appl. Ecol. 4, 107-116.

Halbert, S., Connelly, J., Sandvol, L., 1990. Suction trapping of aphids in western NorthAmerica (emphasis on Idaho). Acta Phytopathol. Hun. 25, 411-422.

Hald, A.B., 1999. Weed vegetation (wild flora) of long established organic versus conventional cereal fields in Denmark. Ann. Appl. Biol. 134, 307-314.

Hasken, K.H., Poehling, H.M., 1995. Effects of different intensities of fertilizers and pesticides on aphids and aphid predators in winter wheat. Agric. Ecosyst. Environ. 52, 45-50.

Honek, A., 1991a. Nitrogen fertilization and abundance of the cereal aphids Metopolophium dirhodum and Sitobion avenae (Homoptera, Aphididae). J. Plant Diseases Protection 98, 655-660.

Honek, A., 1991b. Environment stress, plant-quality and abundance of cereal aphids (Homoptera, Aphididae) on winter-wheat. J. Appl. Entomol. 112, 65-70.

Hyvönen, T., Ketoja, E., Salonen, J., Jalli, H., Tiainen, J., 2003. Weed species diversity and community composition in organic and conventional cropping of spring cereals. Agric. Ecosyst. Environ. 97, 131-149.

Kareiva, P., 1990. Population dynamics in spatially complex environments: theory and data. Phil. Trans. R. Soc. Lond. B 330, 175-190.

Kleijn, D., Berendse, F., Smit, R., Gilissen, N., 2001. Agri-environment schemes do not effectively protect biodiversity in Dutch agricultural landscapes. Nature 413, 723-725.

Krebs, J.R., Wilson, J.D., Bradbury, R.B., Siriwardena, G.M., 1999. The second silent spring? Nature 400, 611-612. 
Kromp, B., 1989. Carabid beetle communities (Carabidae, Coleoptera) in biologically and conventionally farmed agroecosystems. Agric. Ecosyst. Environ. 27, 241-251.

Kruess, A., Tscharntke, T., 1994. Habitat fragmentation, species loss and biological control. Science 264, 1581-1584.

Kruess, A., Tscharntke, T., 2000. Species richness and parasitism in a fragmented landscape: experiments and field studies with insects on Vicia sepium. Oecologia 122, 129-137.

Leather, S.R., 1993. Overwintering in six arable aphid pests: a review with particular relevance to pest management. J. Appl. Ent. 116, 217-233.

Letourneau, D.K., Goldstein, B., 2001. Pest damage and arthropod community structure in organic vs. conventional tomato production in California. J. Appl. Ecol. 38, 557-570.

Matson, P.A., Parton, W.J., Power, A.G., Swift, M.J., 1997. Agricultural intensification and ecosystem properties. Science 277, 504-509.

Melnychuk, N.A., Olfert, O., Youngs, B., Gillott, C., 2003. Abundance and diversity of Carabidae (Coleoptera) in different farming systems. Agric. Ecosyst. Environ. 95, 6972.

Menalled, F.D., Marino, P.C., Gage, S.H., Landis, D.A., 1999. Does agricultural landscape structure affect parasitism and parasitoid diversity? Ecol. Appl. 9, 634-641.

Menalled, F.D., Gross, K.L., Hammond, M., 2001. Weed aboveground and seedbank community responses to agricultural management systems. Ecol. Appl. 11, 1586-1601.

Moreby, S.J., Aebischer, N.J., Southway, S.E., Sotherton, N.W., 1994. A comparison of the flora and arthropod fauna of organically and conventionally grown winter-wheat in southern England. Ann. Appl. Biol. 125, 13-27.

Östman, Ö., Ekbom, B., Bengtsson, J., Weibull, A.C., 2001a. Landscape complexity and farming practice influence the condition of polyphagous carabid beetles. Ecol. Appl. 11, 480-488.

Östman, Ö., Ekbom, B., Bengtsson, J., 2001b. Landscape heterogeneity and farming practice influence biological control. Basic Appl. Ecol. 2, 365-371.

Paoletti, M.G., 1995. Biodiversity, traditional landscapes and agroecosystem management. Landscape Urban Plann. 31, 117-128.

Pickett, S.T.A., Cadenasso, M.L., 1995. Landscape ecology: spatial heterogeneity in ecological systems. Science 269, 331-334.

Polis, G.A., Anderson, W.B., Holt, R.A., 1997. Toward an integration of landscape and food web ecology: the dynamics of spatially subsidized food webs. Annu. Rev. Ecol. Syst. 28, 289-316.

Powell, W., 1986. Enhancing parasitoide activity in crops. In: Waage, J., Greathead, W. (Eds.), Insect parasitoids. Academic Press, pp. 319-340.

Reganold, P.R., Glover, J.D., Andrews, P.K., Hinman, H.R., 2001. Sustainability of three apple production systems. Nature 410, 926-929. 
Ricklefs R.E., Schluter, D., 1993. Species Diversity: Regional and Historical Influences. In: Ricklefs, R.E., Schluter, D. (Eds.), Species diversity in ecological communities: historical and geographical perspectives. The University of Chicago Press, Chicago, pp. 350-363.

Riley, J.R., Reynolds, D.R., Mukhopadhyay, S., Ghosh, M.R., Sarkar, T.K., 1995. Longdistance migration of aphids and other small insects in northeast India. Eur. J. Entomol. 92, 639-653.

Ritchie, M.E., Olff, H., 1999. Spatial scaling laws yield a synthetic theory of biodiversity. Nature 400, 557-560.

Roland, J., Taylor, P.D., 1997. Insect parasitoid species respond to forest structure at different spatial scales. Nature 386, 710-713.

Schmidt, M.H., Lauer, A., Purtauf, T., Thies, C., Schaefer, M., Tscharntke, T., 2003. Relative importance of predators and parasitoids for cereal aphid control. Proc. R. Soc. Lond. B 270, 1905-1909.

Sokal, R.R., Rohlf, F.J., 1995. Biometry, 3. Edition, Freeman \& Company, New York.

Steffan-Dewenter, I., Münzenberg, U., Tscharntke, T., 2001. Pollination, seed set, and seed predation on a landscape scale. Proc. R. Soc. Lond. B 268, 1685-1690.

Steppuhn, A., Wäckers, F., 2002. Can we enhance biological control by providing nectar sources? Verhandlungen der Gesellschaft für Ökologie 32, 66.

Taylor, L.R., 1977. Migration and spatial dynamics of an aphid, Myzus persicae. J. Anim. Ecol. 46, 411-423.

The Soil Association, 2000. The biodiversity benefits of organic farming. http://www.soilassociation.org/web/sa/saweb.nsf/848d689047cb466780256a6b0029898 0/80256ad800554549802568e80048af3d/\$FILE/Biodiversity\%20Report.pdf

Thies, C., Tscharntke, T., 1999. Landscape structure and biological control in agroecosystems. Science 285, 893-895.

Thies, C., Steffan-Dewenter, I., Tscharntke, T., 2003. Effects of landscape context on herbivory and parasitism at different spatial scales. Oikos 101, 18-25.

Tilman, D., Cassman, K.G., Matson, P.A., Naylor, R., Polasky, S., 2002. Agricultural sustainability and intensive production practices. Nature 418, 671-677.

Tischendorf, L., Fahrig, L., 2000. On the usage and measurement of landscape connectivity. Oikos 90, 7-19.

Triltsch, H., Gosselke, U., Freier, B., Roßberg, D., 1998. Zum Phänomen der schnelleren Entwicklung von Insekten bei Wechseltemperaturen. Mitt. Biol. Bundesanstalt 357, 1239.

Tscharntke, T., Kruess, A., 1999. Habitat fragmentation and biological control. In: Hawkins, B.A., Cornell, H.V. (Eds.), Theoretical approaches to biological control. Cambridge University Press, pp. 190-205. 
Turner, M.G., Gardner, R.H., 1991. Quantitative methods in landscape ecology. SpringerVerlag, New York.

Wäckers, F.L., 1994. The effect of food deprivation on the innate visual and olfactory preferences in the parasitoid Cotesia rubecula. J. Insect Physiology 40, 641-649.

Wäckers, F.L., Swaans, C.P.M., 1993. Finding floral nectar and honeydew in Cotesia rubecula: random or direct? Proc. Exp. Appl. Entomol. 4, 67-72.

Weibull, A.C., Bengtsson, J., Nohlgren, E., 2000. Diversity of butterflies in the agricultural landscape: the role of farming system and landscape heterogeneity. Ecography 23, 743 750 .

Weibull, A.C., Östman, Ö., 2003. Species composition in agroecosystems: The effect of landscape, habitat, and farm management. Basic Appl. Ecol. 4, 349-361.

Weibull, A.C., Östman, Ö., Granqvist, A., 2003. Species richness in agroecosystems: The effect of landscape, habitat and farm management. Biodivers. Conserv. 12, 1335-1355.

Whittaker, R.J., Willis, K.J., Field, R., 2001. Scale and species richness: towards a general, hierarchical theory of species diversity. J. Biogeogr. 28, 453-470.

With, K.A., Cadaret, S.J., Davis, C., 1999. Movement responses to patch structure in experimental fractal landscapes. Ecology 80:1340-1353.

Wratten, S.D., Van Emden, H.F., 1995. Habitat management for enhanced activity of natural enemies of insect pests. In: Glen, D.M., Greaves, M.P., Anderson, H.M. (Eds.), Ecology and integrated farming systems. Wiley and Sons, pp. 117-145. 


\section{Chapter 8}

The role of arable weeds in cereal aphid-natural enemy interactions

Indra Roschewitz, Teja Tscharntke \& Carsten Thies

Submitted

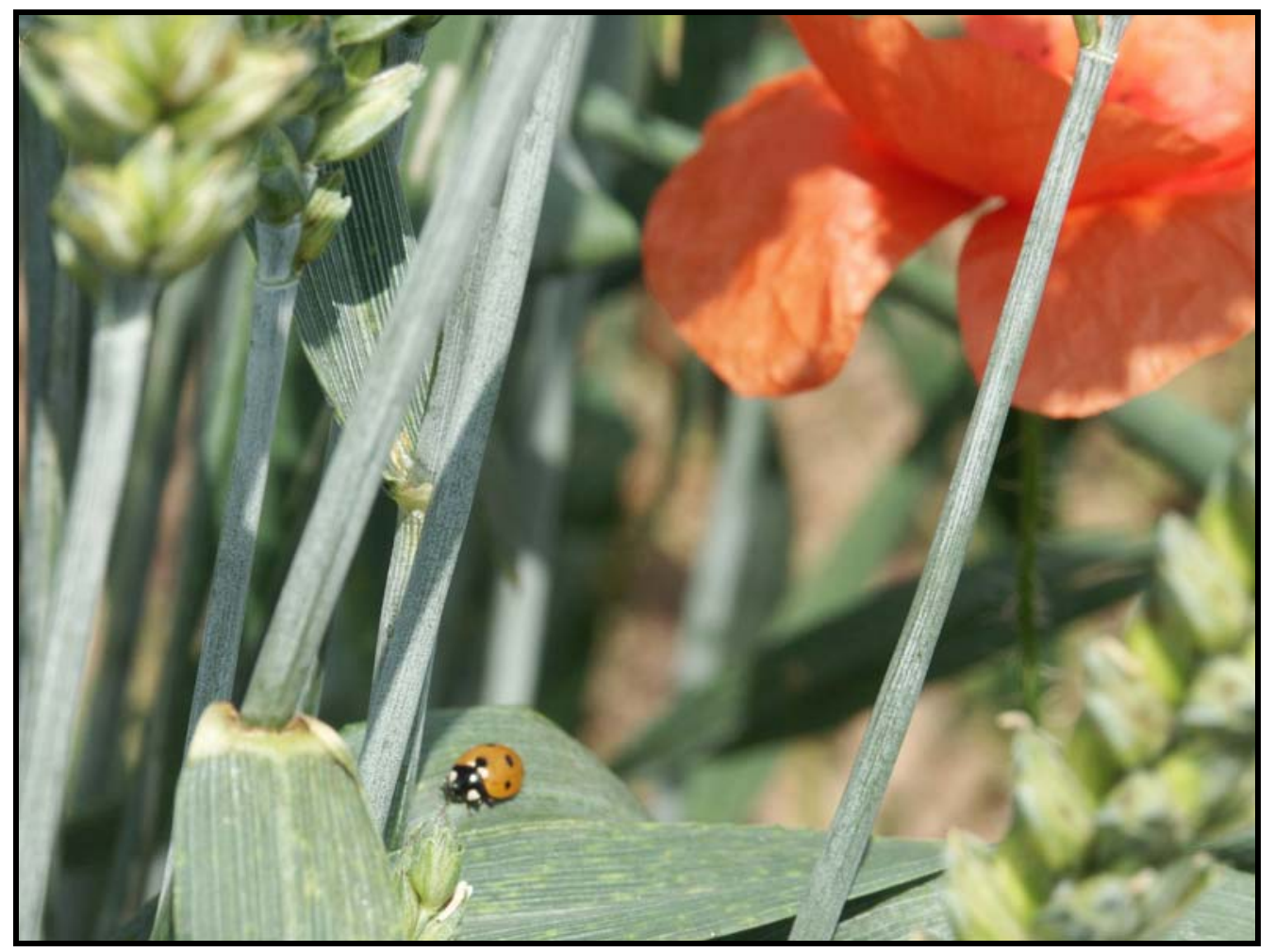




\begin{abstract}
Habitat diversification is hypothesised to reduce insect pest colonisation and to enhance the efficiency of natural enemies, thereby leading to an improvement of biological control. We studied the densities of cereal aphids and their natural enemies, predators and parasitoids, in a wheat field with weed treatments including six herbaceous, six grass, and six herbaceous plus six grass species, respectively, with either 5 or $20 \%$ vegetation cover. The naturally occurring aphid Metopolophium dirhodum colonised the weedless control in 388\% higher densities than the herb plus grass treatment with $20 \%$ cover. Flying predator densities (but not parasitoid densities) were enhanced by weeds, especially when herbs plus grasses covered $20 \%$. This appeared to be the reason why released populations of Sitobion avenae and naturally occurring aphids were lowest in this treatment ( 5 aphids/shoot instead of 23 in the control), thereby falling below the threshold level of economic damage. Losses of wheat biomass due to competition of weeds were not detected, and therefore seemed to be compensated by lower aphid abundance. Hence, a reduction of herbicide use might be expected to reduce the necessity of insecticide applications, thereby both supporting plant biodiversity and benefit from important ecosystem services for sustainable agriculture.
\end{abstract}

\title{
Key words
}

Aphid parasitoids; aphid predators; biological control; diversification; enemies hypothesis; resource concentration 


\section{Introduction}

Intensive use of chemical pesticides in agroecosystems led to many environmental problems such as the contamination of soils and water and losses of biodiversity (Matson et al. 1997; Krebs et al. 1999; Tilman et al. 2002). However, as insect pests like cereal aphids can cause great economically damage in years of high abundance (Östman et al. 2003), they often have to be controlled using insecticides. An alternative to spraying insecticides may be promoting their naturally occurring enemies. The role of natural enemies in preventing aphid outbreaks was emphasised in several studies (e.g., Wratten \& Powell 1991; Levie et al. 2000; Kindlmann \& Dixon 2001; Sigsgaard 2002; Schmidt et al. 2003; Thies et al. 2005). Natural enemy populations can be enhanced by diverse vegetation, providing alternative hosts or prey, and pollen and nectar resources for adult insects, whose larvae are entomophagous (Powell et al. 1986; Schellhorn \& Sork 1997; Elliott et al. 1998; Murphy et al. 1998; Banks 2000; Banks $\&$ Stark 2004). An increase of the fitness of individual insects receiving resource subsidies was also reported (Tylianakis et al. 2004). This is all in support of Root's (1973) enemies hypothesis, predicting that predators and parasitoids are more effective in diverse than in simple systems. While many studies show the influence of diverse plant communities that are spatially separated from the crop, situated in e.g. field margins or flowering strips (but see Powell et al. 1986; Schellhorn \& Sork 1997; Elliott et al. 1998), naturally occurring arable weeds, mixed up with the crop, should especially favour natural aphid enemies because of the spatial proximity. Additionally, according to the resource concentration hypothesis (Root 1973), aphids should colonise cereal monocultures in higher densities than weedy fields due to a more easily finding of host plants.

The cereal aphids Sitobion avenae F., Metopolophium dirhodum Walk. and Rhopalosiphum padi L. are the most common pests on cereals in Germany. Several groups of natural enemies may limit aphid populations: flying and ground-dwelling predators (Wratten \& Powell 1991; Holland et al. 1996; Holland \& Thomas 1997; Östman et al. 2001; Symondson et al. 2002; Lang 2003), and parasitoid wasps (Hymenoptera: mainly Aphidiidae) specialised on one or several aphid host species (Sigsgaard 2002). Schmidt et al. (2003) experimentally showed that parasitoids were the main contributors to reducing aphid densities in our region, but this seems only to be valid in years of low aphid abundance (Thies et al. 2005).

In this study, we tested whether the abundance of weeds (herbs and/or grasses with 5 and 20\% vegetation cover, respectively) influences cereal aphid colonisation as well as aphid and natural enemy (flying predators and parasitoid wasps) abundance over a time span of five weeks in winter wheat (Triticum aestivum L.). We hypothesised that high cover of arable weeds should (i) decrease aphid colonisation of the wheat and (ii) increase the abundance of natural enemies, further reducing aphid densities. Herbaceous weeds should have a greater positive effect on predator and parasitoid abundance than grasses because of enhanced pollen and nectar resources (cf. Schellhorn \& Sork 1997). However, grasses should also be 
important, especially for parasitoids, as aphids feeding on grasses can act as alternative hosts (Powell et al. 1986).

\section{Material and methods}

The experiment was carried out in 2003 in a winter wheat field $(45 \mathrm{~m} \times 45 \mathrm{~m})$ of the Department of Agroecology in Göttingen (Lower Saxony, Germany). The wheat (c.v. Skater) was drilled on 5 October 2002, with a $30 \mathrm{~cm}$ distance between the rows (200 grains $/ \mathrm{m}^{2}$, $108 \mathrm{~kg} / \mathrm{ha}$ ). Nitrogen fertilizer (KAS, $27 \% \mathrm{~N}, 2 \times 54 \mathrm{kgN} / \mathrm{ha}$ ) was applied on $25 \mathrm{March}$ and on 6 April 2003. We established 42 experimental plots (seven treatments with 6 replications) with a size of $3 \mathrm{~m} \times 3 \mathrm{~m}$, each enclosed by a $3 \mathrm{~m}$ wide buffer strip: 1) no weeds (W0), 2) six herb species, $5 \%$ vegetation cover (H5), 3) six grass species, $5 \%$ vegetation cover (G5), 4) six herb and six grass species, 5\% vegetation cover (HG5), 5) six herb species, $20 \%$ vegetation cover (H20), 6) six grass species, 20\% vegetation cover (G20), 7) six herb and six grass species, 20\% vegetation cover (HG20). On 09 April 2003, the experimental plots were sown with the herb species Centaurea cyanus L., Lamium purpureum L., Matricaria perforata Mérat, Papaver rhoeas L., Sinapis arvensis L., Viola arvensis Murray, and the grass species Alopecurus myosuroides Huds., Apera spica-venti (L.) P. Beauv., Avena fatua L., Bromus sterilis L., Poa annua L., and Poa trivialis L., which are all common weed species in our region. The treatments were arranged randomly within the 42 plots. To prevent weed growing in W0 and in the buffer strips, the herbicides Starane (1L/ha) against herbs and Efes IPU 500 (1.5L/ha) against grasses were sprayed once on 7 May 2003. Additionally, all only-herb plots were sprayed against grasses and all only-grass plots against herbs (with the same herbicides and application rates as in W0). To reach the right percentage vegetation cover, all plots were controlled weekly until the end of the experiment, and, if necessary, weeds were removed by hoeing.

To ensure similar initial population sizes of one aphid species in all plots, Sitobion avenae were reared in a greenhouse on potted summer wheat and released in the plots (two Sitobion avenae per wheat shoot) on 17 June 2004. Population densities of the cereal aphids Sitobion avenae, Metopolophium dirhodum, and Rhopalosiphum padi, of mummified aphids (by parasitic wasps (Hymenoptera: mainly Aphidiidae)), and of several aphid predators (larvae and adults of ladybird beetles (Coccinellidae), and larvae of hoverflies (Syrphidae), lacewings (Chrysopidae), and gall midges (Cecidomyiidae)) were counted five times, weekly from 23 June to 21 July 2004. Aphids, mummies and predators were counted on 50 wheat shoots per plot. Thereby all mummies (unhatched and also already hatched) were included to prevent possible underestimation of parasitism, as parasitised but not yet mummified aphids were not included in this sampling method. At the end of the experiment, 50 wheat shoots per plot were harvested and dried at room temperature to quantify plant biomass. 
Aphid, mummy and predator densities (per 50 wheat shoots) were added up for the five sampling dates. Analyses of covariance (ANCOVA) were used to measure the influence of the different treatments on individual numbers of aphids, predators, and aphid mummies. Host and prey densities, respectively (number of wheat shoots $/ \mathrm{m}^{2}$ for the aphids, number of aphids $/ 50$ wheat shoots for the natural enemies) were included in the statistical models as covariates. To simplify the models, non-significant variables were removed. Logarithmic transformation of the variables $(\ln (x+1))$ was used to achieve normality of the residuals from the statistical models, and arcsine-square-root transformations of the percentages (Sokal and Rohlf 1995). In the text and tables, arithmetic means \pm one standard deviation (SD) are given.

\section{Results}

A total of 348216 aphids was counted in the experimental plots, of which $85.8 \%$ were Sitobion avenae, 10.8\% Metopolophium dirhodum, and 3.4\% Rhopalosiphum padi. They were attacked by larvae and adults of ladybird beetles, larvae of gall midges, hoverflies and lacewings, and by parasitoids. The population densities of aphids and their natural enemies are summarised in Table 1 for the five sampling dates. Aphid densities increased from the first to the fourth sampling and than rapidly decreased. Predator and parasitoid densities showed a numerical response to aphid densities and generally increased from the first to the fifth sampling. The initial population sizes of $M$. dirhodum in the W0 plots $(80.58 \pm 58.37$ aphids/50 wheat shoots) were approx. four times higher than in the HG20 plots $(20.75 \pm 16.38$ aphids/50 wheat shoots)(ANCOVA: $F=3.07 ; p<0.05$ ). Densities of all aphids, $S$. avenae, and $R$. padi at the first sampling date did not yet differ between the seven treatments (ANCOVA: $F=1.48 ; p>0.1 ; F=1.23 ; p>0.1 ; F=0.34 ; p>0.1$, respectively).

Aphid densities showed significant weed treatment effects when cumulated for the five sampling dates (Fig. 1, Table 2). They were generally higher in the W0 than in the HG20 plots: total aphid densities in W0 were $504.1 \%$ as high as in HG20, S. avenae densities 478.8\%, M. dirhodum densities 541.7\%, and $R$. padi densities even $889.5 \%$. Densities of all aphids and $S$. avenae in the W0 plots were also higher than in the G20 plots. The other weed treatments did not significantly decrease aphid densities, but showed a similar trend. Densities of $M$. dirhodum and $R$. padi decreased with increasing density of wheat shoots, whereas $S$. avenae and all aphids were not related to host plant density. 
Table 1. Aphid, predatory insect, and aphid mummy densities on 50 wheat shoots at five sampling dates. Means $\pm \mathrm{SD}$ are given for 42 plots.

\begin{tabular}{|c|c|c|c|c|c|c|}
\hline & Date 1 & Date 2 & Date 3 & Date 4 & Date 5 & cumulated \\
\hline \multicolumn{7}{|l|}{ Aphids: } \\
\hline All & $194.5 \pm 104.4$ & $445.8 \pm 293.6$ & $822.7 \pm 569.0$ & $1365.9 \pm 1307.4$ & $133.7 \pm 279.7$ & $2962.6 \pm 2099.6$ \\
\hline S. avenae & $145.2 \pm 78.7$ & $323.3 \pm 211.9$ & $594.8 \pm 406.6$ & $1073.4 \pm 972.9$ & $127.7 \pm 268.5$ & $2264.4 \pm 1564.2$ \\
\hline M. dirhodum & $40.5 \pm 32.4$ & $106.7 \pm 71.9$ & $198.6 \pm 167.7$ & $215.5 \pm 245.9$ & $2.5 \pm 6.9$ & $563.9 \pm 459.2$ \\
\hline R. padi & $8.8 \pm 17.3$ & $15.8 \pm 31.0$ & $29.4 \pm 38.9$ & $77.0 \pm 130.2$ & $3.4 \pm 9.3$ & $134.4 \pm 162.0$ \\
\hline \multicolumn{7}{|c|}{ Aphid predators: } \\
\hline All & $2.3 \pm 1.4$ & $4.5 \pm 3.2$ & $5.9 \pm 3.9$ & $14.4 \pm 15.1$ & $11.1 \pm 11.1$ & $38.0 \pm 21.3$ \\
\hline $\begin{array}{l}\text { Ladybird } \\
\text { beetles }^{1}\end{array}$ & $1.3 \pm 0.9$ & $1.9 \pm 1.6$ & $0.9 \pm 1.3$ & $1.6 \pm 4.9$ & $5.6 \pm 7.4$ & $11.4 \pm 9.8$ \\
\hline Gall midges $^{2}$ & $0.2 \pm 0.7$ & $0.9 \pm 1.4$ & $2.1 \pm 2.6$ & $4.6 \pm 7.0$ & $1.2 \pm 2.6$ & $9.0 \pm 8.4$ \\
\hline Hoverflies $^{2}$ & $0.7 \pm 0.8$ & $1.6 \pm 1.5$ & $2.4 \pm 1.8$ & $6.1 \pm 4.8$ & $2.3 \pm 2.6$ & $13.1 \pm 7.1$ \\
\hline Lacewings $^{2}$ & $0.1 \pm 0.3$ & $0.1 \pm 0.3$ & $0.5 \pm 1.0$ & $2.0 \pm 4.5$ & $2.0 \pm 1.8$ & $4.6 \pm 4.6$ \\
\hline \multicolumn{7}{|c|}{ Aphid mummies: } \\
\hline All & $0.7 \pm 0.8$ & $2.8 \pm 4.5$ & $5.6 \pm 5.4$ & $17.0 \pm 13.7$ & $19.7 \pm 15.2$ & $45.7 \pm 29.8$ \\
\hline S. avenae & $0.4 \pm 0.5$ & $1.5 \pm 1.5$ & $4.7 \pm 4.7$ & $14.6 \pm 11.2$ & $19.0 \pm 14.6$ & $40.2 \pm 25.8$ \\
\hline M. dirhodum & $0.2 \pm 0.5$ & $0.8 \pm 1.2$ & $0.9 \pm 1.3$ & $2.3 \pm 3.5$ & $0.6 \pm 1.3$ & $4.8 \pm 4.5$ \\
\hline R. padi & $0.01 \pm 0.08$ & $0.6 \pm 3.9$ & $0.02 \pm 0.2$ & $0.1 \pm 0.5$ & $0.1 \pm 0.3$ & $0.8 \pm 4.0$ \\
\hline
\end{tabular}

${ }_{2}^{1}$ larvae and adults

${ }^{2}$ larvae

Aphid predator densities also responded to weed abundance (Table 2) and were lower in the W0 than in all other treatments, and lower in the HG5 than in the HG20 plots (Fig. 2a). Additionally, they increased with increasing prey density. In particular, ladybird beetles (larvae plus adults) and gall midge larvae revealed a similar pattern (Fig. 2b, c). The ladybird beetle densities were lower in the W0 than in all herb and herb plus grass treatments, but not in the grass treatments. The difference between gall midge larvae densities was significant for the two extremes W0 and HG20. Densities of the hoverflies and lacewings - although not significant - showed a similar trend to be enhanced by higher weed cover (Fig. 2d, e), whereas aphid mummies did not response to the weed treatments (Fig. 2f). The biomass of the wheat plants $(257.3 \pm 25.7 \mathrm{~g} / 50$ wheat shoots; min.: $207.1 \mathrm{~g}$, max.: $304.3 \mathrm{~g})$ did not differ between the treatments (ANOVA: $F=1.81 ; p>0.1$ ). 
Table 2. Aphid, predatory insect, and aphid mummy densities on 50 wheat shoots cumulated for five sampling dates in dependence of weed treatment and wheat and aphid densities, respectively. $F$-values, levels of significance, and $r^{2}$-values ( $\%$ ) from ANCOVA, $n=42$ plots.

\begin{tabular}{|c|c|c|c|}
\hline & $F$ & $p$ & $r^{2}$ \\
\hline \multicolumn{4}{|l|}{ Aphids: } \\
\hline \multicolumn{4}{|l|}{ All } \\
\hline Weed treatment & 6.86 & $<0.001$ & \\
\hline Wheat shoots $/ \mathrm{m}^{2}$ & - & - & \\
\hline Model & 6.86 & $<0.001$ & $54.04 \%$ \\
\hline \multicolumn{4}{|l|}{ S. avenae } \\
\hline Weed treatment & 7.36 & $<0.001$ & \\
\hline Wheat shoots $/ \mathrm{m}^{2}$ & - & - & \\
\hline Model & 7.36 & $<0.001$ & $55.80 \%$ \\
\hline \multicolumn{4}{|l|}{ M. dirhodum } \\
\hline Weed treatment & 3.86 & $<0.01$ & \\
\hline Wheat shoots $/ \mathrm{m}^{2}$ & $10.57^{3}$ & $<0.001$ & \\
\hline Model & 4.84 & $<0.001$ & $49.92 \%$ \\
\hline \multicolumn{4}{|l|}{ R. padi } \\
\hline Weed treatment & 2.81 & $<0.05$ & \\
\hline Wheat shoots $/ \mathrm{m}^{2}$ & $4.58^{3}$ & $<0.05$ & \\
\hline Model & 3.01 & $<0.05$ & $38.29 \%$ \\
\hline \multicolumn{4}{|l|}{ Aphid predators: } \\
\hline \multicolumn{4}{|l|}{ All } \\
\hline Weed treatment & 5.27 & $<0.001$ & \\
\hline Aphids/50 wheat shoots & $66.59^{4}$ & $<0.001$ & \\
\hline Model & 11.07 & $<0.001$ & $69.50 \%$ \\
\hline \multicolumn{4}{|l|}{ Ladybird beetles $^{1}$} \\
\hline Weed treatment & 4.18 & $<0.01$ & \\
\hline Aphids/50 wheat shoots & $37.09^{4}$ & $<0.001$ & \\
\hline Model & 6.86 & $<0.001$ & $58.54 \%$ \\
\hline \multicolumn{4}{|l|}{ Gall midges $^{2}$} \\
\hline Weed treatment & 2.74 & $<0.05$ & \\
\hline Aphids/50 wheat shoots & $21.19^{4}$ & $<0.001$ & \\
\hline Model & 3.43 & $<0.001$ & $41.41 \%$ \\
\hline
\end{tabular}


Table 2. continued

\begin{tabular}{|c|c|c|c|}
\hline & $F$ & $p$ & $r^{2}$ \\
\hline \multicolumn{4}{|l|}{ Hoverflies $^{2}$} \\
\hline Weed treatment & - & - & \\
\hline Aphids/50 wheat shoots & $23.08^{4}$ & $<0.001$ & \\
\hline Model & 23.08 & $<0.001$ & $36.58 \%$ \\
\hline \multicolumn{4}{|l|}{ Lacewings $^{2}$} \\
\hline Weed treatment & - & - & \\
\hline Aphids/50 wheat shoots & $10.91^{4}$ & $<0.01$ & \\
\hline Model & 10.91 & $<0.01$ & $21.43 \%$ \\
\hline \multicolumn{4}{|l|}{ Aphid mummies: } \\
\hline \multicolumn{4}{|l|}{ All } \\
\hline Weed treatment & - & - & \\
\hline Aphids/50 wheat shoots & $87.67^{4}$ & $<0.001$ & \\
\hline Model & 87.67 & $<0.001$ & $68.67 \%$ \\
\hline \multicolumn{4}{|l|}{ S. avenae } \\
\hline Weed treatment & - & - & \\
\hline Aphids/50 wheat shoots & $64.27^{4}$ & $<0.001$ & \\
\hline Model & 64.27 & $<0.001$ & $61.64 \%$ \\
\hline \multicolumn{4}{|l|}{ M. dirhodum } \\
\hline Weed treatment & - & - & \\
\hline Aphids/50 wheat shoots & $120.93^{4}$ & $<0.001$ & \\
\hline Model & 120.93 & $<0.001$ & $75.15 \%$ \\
\hline \multicolumn{4}{|l|}{ R. padi } \\
\hline Weed treatment & - & - & \\
\hline Aphids/50 wheat shoots & $5.61^{4}$ & $<0.05$ & \\
\hline Model & 5.61 & $<0.05$ & $12.30 \%$ \\
\hline
\end{tabular}


(a) All aphids

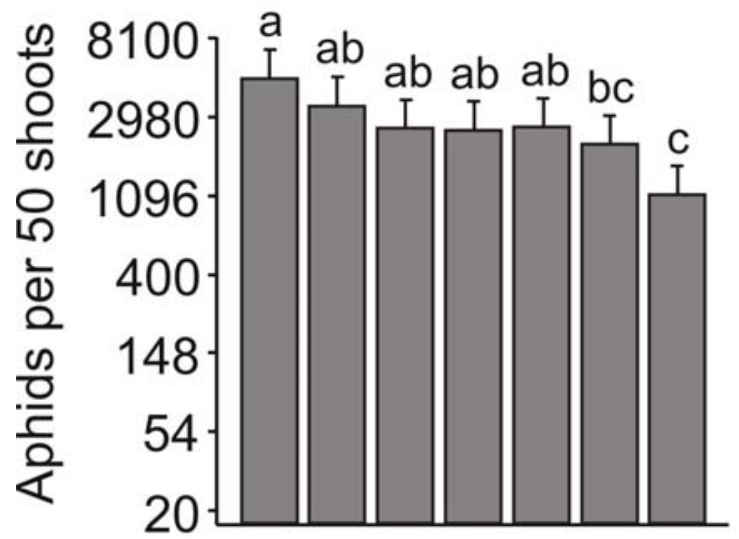

(c) M. dirhodum

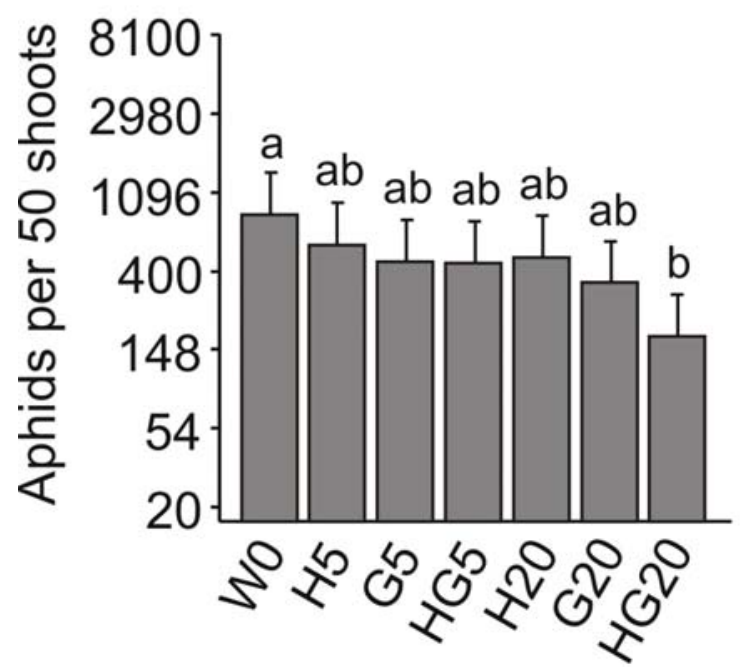

(b) S. avenae

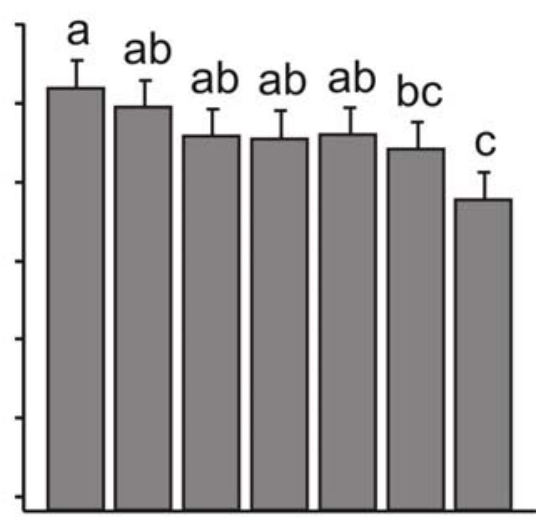

(d) R. padi

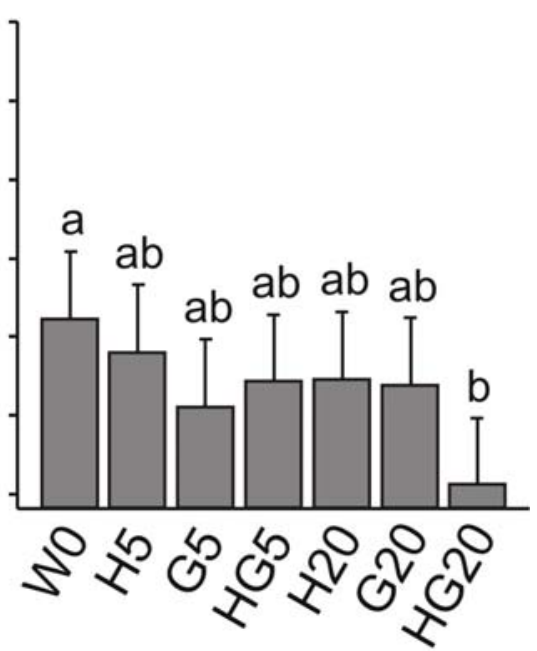

Figure 1. Aphid densities on 50 wheat shoots cumulated for five sampling dates in different weed treatments. (a) All aphids, (b) S. avenae, (c) M. dirhodum, (d) R. padi. Results of ANCOVA with treatment as factor and wheat shoots $/ \mathrm{m}^{2}$ as covariate (see Table 2), means and 95\% Tukey intervals are shown; $n=42$ plots. W0 = no weeds, $\mathrm{H}=$ herbs, $\mathrm{G}=$ grasses, $5=5 \%$ vegetation cover, $20=20 \%$ vegetation cover. 
(a) All predators

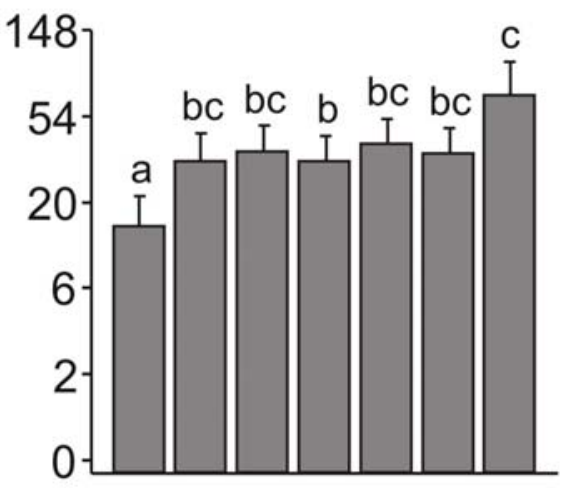

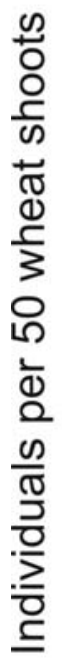

(b) Ladybird beetles

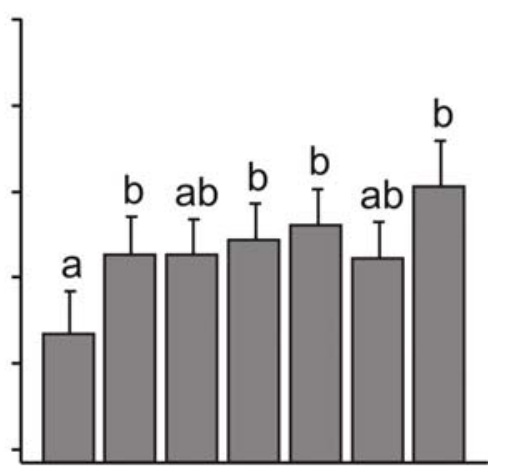

(d) Hoverfly larvae

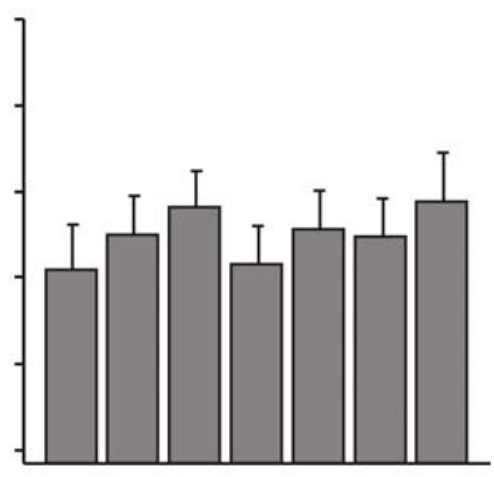

(f) Aphid mummies

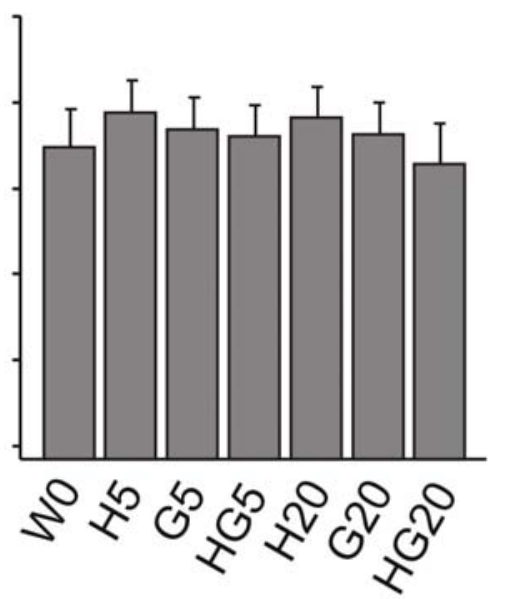

Weed treatment

Figure 2. Natural aphid enemy densities on 50 wheat shoots cumulated for five sampling dates in different weed treatments. (a) All predators, (b) Ladybird beetle adults and larvae, (c) Gall midge larvae, (d) Hoverfly larvae, (e) Lacewing larvae, (f) Aphid mummies. Results of ANCOVA with treatment as factor and aphids/50 wheat shoots as covariate (see Table 2), means and 95\% Tukey intervals are shown; $n=42$ plots. W0= no weeds, $\mathrm{H}=$ herbs, $\mathrm{G}=$ grasses, $5=5 \%$ vegetation cover, $20=20 \%$ vegetation cover. 


\section{Discussion}

In this study, the abundance of arable weeds in winter wheat negatively affected aphid colonisation in the beginning as well as overall aphid density during the time of the experiment, due to enhanced natural enemy abundance. Especially a mixture of herbs and grasses covering $20 \%$ of the soil decreased aphid colonisation and abundance over time and increased predator densities, while an effect on parasitoid densities could not be found. Wheat biomass did not differ between the treatments, suggesting that the potential losses in biomass resulting from resource competition between wheat and weeds were compensated by the lower aphid densities in the weedy treatments.

The colonisation of the wheat plants by $M$. dirhodum was higher in plots with no weeds than in plots with $20 \%$ cover of herbs plus grasses, thereby supplying evidence that specialist herbivores more easily find monocultures of their host plants (Root's (1973) resource concentration hypothesis). Initial population densities of $R$. padi did not differ between the treatments, which might be due to the generally small number of individuals. The density of all aphids also did not differ between the treatments, as it was dominated by $S$. avenae $(75 \%$ of all aphids at the time of colonisation), which was released in all plots with similar densities. Over time, the abundance of all aphids as well as of each aphid species was lowest when a mixture of herbs and grasses covered $20 \%$ of the soil. All aphids and S. avenae also had lower densities than in the weedless control when only grasses covered 20\%. Aphid densities in the other weed treatments showed similar, but not significant tendencies. Converted to number of aphids per one wheat shoot and one sampling date, in the weedless control, 23 individuals/wheat shoot*sampling date were found, while it were only 5 individuals in the HG20 plots. Aphid numbers in the other weed treatments were quite similar and varied between 8 and 15 individuals/wheat shoot*sampling date. So, only aphids in the HG20 plots did not exceed the threshold level of economic damage (3-5 aphids per shoot; Pflanzenschutzamt Hannover 2002).

In all weed treatments, predator densities were at least three times higher than in the weedless control (Figure 2). Higher predator populations in diverse plant assemblages are consistent with most of the published literature (e.g., see Russell 1989; van Emden 1990; Andow 1991). Especially ladybird beetles seem to have profited from herbs, as their densities were enhanced in all treatments that included herbs, but not in the only grass treatments. As ladybird beetles are generalist aphid predators, both herbs and grasses can act as hosts for alternative aphid prey, but besides feeding on aphids, ladybird beetles are known to feed on pollen and nectar (e.g., Pemberton \& Vandenberg 1993; Triltsch 1997; Coll \& Guershon 2002), which they find on herbs, but not grasses.

In contrast to Schmidt et al. (2003), aphid parasitoids were of minor importance in aphid control in our study. They appeared in relatively low densities and irrespective of weed treatment, and the mean parasitism rate of $1.6 \%$ was clearly below the threshold value of 32 - 
$36 \%$, below which success in classical biological control has never been found (Hawkins \& Cornell 1994). As aphid densities were extremely high right from the beginning of the experiment, this suggests that parasitoids might only successfully control the aphids in years of low aphid abundances, thereby supporting the findings of Thies et al. (2005). The high aphid abundance might also explain why parasitoids unexpectedly did not profit from the grasses, which were expected to provide alternative hosts (Powell et al. 1986).

In conclusion, this study gives evidence that diverse weed communities with high percent vegetation cover in wheat fields can support biological control of cereal aphids. Weeds reduced aphid colonisation and supported naturally occurring aphid predators, thereby leading to a decrease in the abundance of all aphids of $\sim 500 \%$, and falling below the threshold level of economic damage. Potential losses in wheat biomass resulting from the competition between wheat and weeds appeared to be compensated by the lower aphid densities. Hence, reduced herbicide use may lead to a reduction of insecticide applications, thereby possibly establishing environmentally more sound farming practices supporting plant biodiversity as well as benefiting from important ecosystem services for sustainable food production.

\section{Acknowledgements}

We are grateful to Melanie Hücker, Mechthild Rittmeier, Uli Thewes and Mirko Enge for assistance in the field, and the German Science Foundation (DFG) for financial support.

\section{References}

Andow, D.A. 1991 Vegetational diversity and arthropod population response. Annu. Rev. Entomol. 36, 561-586.

Banks, J.E. 2000 Effects of weedy field margins on Myzus persicae (Hemiptera: Aphididae) in a broccoli agroecosystem. Pan-Pac. Entom. 76, 95-101.

Banks, J.E. \& Stark, J.D. 2004 Aphid response to vegetation diversity and insecticide applications. Agr. Ecosyst. Environ. 103, 595-599.

Coll, M. \& Guershon, M. 2002 Omnivory in terrestrial arthropods: Mixing plant and prey diets. Annu. Rev. Entomol. 47, 267-97.

Elliott, N.C., Kieckhefer, R.W., Lee, J.H. \& French, B.W. 1998 Influence of within-field and landscape factors on aphid predator populations in wheat. Landscape Ecol. 14, 239-252.

Hawkins, B.A. \& Cornell, H.V. 1994 Maximum parasitism rates and successful biological control. Science 266, 1886. 
Holland, J.M. \& Thomas, S.R. 1997 Quantifying the impact of polyphagous invertebrate predators in controlling cereal aphids and in preventing wheat yield and quality reductions. Ann. Appl. Biol. 131, 375-397.

Holland, J.M., Thomas, S.R. \& Hewitt, A. 1996 Some effects of polyphagous predators on an outbreak of cereal aphid (Sitobion avenae F.) and orangewheat blossom midge (Sitodoplosis mosellana Gehin). Agr. Ecosyst. Environ. 59, 181-190.

Kindlmann, P. \& Dixon, A.F.G. 2001 When and why top-down regulation fails in arthropod predator-prey systems. Basic Appl. Ecol. 2, 333-340.

Krebs, J.R., Wilson, J.D., Bradbury, R.B. \& Siriwardena, G.M. 1999 The second silent spring? Nature 400, 611-612.

Lang, A. 2003 Intraguild interferences and biocontrol effects of generalist predators in a winter wheat field. Oecologia 134, 144-153.

Levie, A., Dogot, P. \& Hance, T. 2000 Release of Aphidius rhopalosiphi (Hymenoptera: Aphidiinae) for cereal aphid control: field cage experiments. Eur. J. Entomol. 97, $527-$ 531.

Matson, P.A., Parton, W.J., Power, A.G., Swift, M.J. 1997 Agricultural intensification and ecosystem properties. Science 277, 504-509.

Murphy, B.C., Rosenheim, J.A., Dowell, R.V. \& Granett, J. 1998 Habitat diversification tactic for improving biological control: parasitism of the western grape leafhopper. Entomol. Exp. Appl. 87, 225-235.

Östman, Ö., Ekbom, B., Bengtsson, J. 2001 Landscape heterogeneity and farming practice influence biological control. Basic Appl. Ecol. 2, 365-371.

Östman, Ö., Ekbom, B. \& Bengtsson, J. 2003 Yield increase attributable to aphid predation by ground-living polyphagous natural enemies in spring barley in Sweden. Ecol. Econom. 45, 149-158.

Pemberton, R.W. \& Vandenberg, N.J. 1993 Extrafloral nectar feeding by ladybird beetles (Coleoptera, Coccinellidae). Proc. Entomol. Soc. Wash. 95, 139-151.

Pflanzenschutzamt Hannover, 2002 Pflanzenbau und Pflanzenschutz - Empfehlungen 2002/2003. Diaprint, Hannover.

Powell, W., Dean, the late G.J. \& Wilding, N. 1986 The influence of weeds on aphid-specific natural enemies in winter wheat. Crop Prot. 5, 182-189.

Root, R.B. 1973 Organization of a plant-arthropod association in simple and diverse habitats: The fauna of collards (Brassica oleraceae). Ecol. Monogr. 43, 95-124.

Russell, E.P. 1989 Enemies Hypothesis: A review of the effect of vegetational diversity on predatory insects and parasitoids. Environ. Entomol. 18, 590-599.

Schellhorn, N.A. \& Sork, V.L. 1997 The impact of weed diversity on insect population dynamics and crop yield in collards, Brassica oleraceae (Brassicaceae). Oecologia 111, 233-240. 
Schmidt, M.H., Lauer, A., Purtauf, T., Thies, C., Schaefer, M. \& Tscharntke, T. 2003 Relative importance of predators and parasitoids for cereal aphid control. Proc. R. Soc. Lond. B. 270, 1905-1909.

Sigsgaard, L. 2002 A survey of aphids and aphid parasitoids in cereal fields in Denmark, and the parasitoids' role in biological control. J. Appl. Ent. 126, 101-107.

Sokal, R.R., Rohlf, F.J., 1995. Biometry. 3rd Edition, Freeman \& Company, New York.

Symondson, W.O.C., Sunderland, K.D. \& Greenstone, H.M. 2002 Can generalist predators be effective biocontrol agents? Annu. Rev. Entomol. 47, 561-594.

Thies, C., Roschewitz, I. \& Tscharntke, T. 2005 The landscape context of cereal aphidparasitoid interactions. Proc. R. Soc. Lond. B. 272, 203-210.

Tilman, D., Cassman, K.G., Matson, P.A., Naylor, R. \& Polasky, S. 2002 Agricultural sustainability and intensive production practices. Nature 418, 671-677.

Triltsch, H. 1997 Contents in field sampled adults of Coccinella septempunctata (Col.: Coccinellidae). Entomophaga 42, 125-131.

Tylianakis, J.M., Didham, R.K. \& Wratten, S.D. 2004 Improved fitness of aphid parasitoids receiving resource subsidies. Ecology 85, 658-666.

van Emden, H.F. 1990. Plant diversity and natural enemy efficiency in agroecosystems. In Critical Issues in Biological Control (ed. M. Mackauer, L.E. Ehler \& J. Roland), pp. 63-80. Intercept Ltd, Andover, United Kingdom.

Wratten, S.D. \& Powell, W. 1991 Cereal aphids and their natural enemies. In The ecology of temperate cereal fields. 32nd Symp. Br. Ecol. Soc. (ed. I. G. Firbank, N. Carter, J. F. Darbyshire \& G. R. Potts), pp. 233-257.Oxford: Blackwell Scientific. 


\section{Summary}

The intensification of agricultural practices and the increase of area under agricultural production, which was accompanied by a destruction of perennial habitats, made agriculture to one of the main causers of biodiversity losses. Decreasing species richness may lead to a loss of important ecosystem functions such as biological pest control, which in turn can have negative impacts on agricultural production. Annual crop fields are predominately habitats for organisms, which spend parts of their life cycle in other, perennial habitats. Though annual arable weed populations outlast with their seedbank, they can also benefit from the seed rain from the surrounding landscape. Thus, it is not only important to support the survival conditions within the fields (e.g., by extensive management like organic farming), but also consider the structure of the landscape. In this study, the relative importance of farming system (organic vs. conventional) and landscape complexity on species richness of arable weeds, species richness and activity densities of carabid beetles and ground-dwelling spiders, and for biocontrol of cereal aphids by parasitoid wasps was analysed. In addition, the role of arable weeds in cereal aphid-natural enemy interactions was analysed using a field experiment.

The majority of investigations was conducted in altogether 72 winter wheat fields in the vicinity of Göttingen (one organic and one conventional field in 12 landscape sectors per year). Because the analysis of land-use intensity revealed heterogeneous relations with landscape complexity, in the following studies, study sites were selected trying to keep parameters as field size, pesticide use and use of mineral fertilizers as constant as possible. The regional diversity of arable weed species was strongly determined by the heterogeneity among fields. At the field scale, organic farming generated higher weed species diversity, but conventional farming reached similar diversity levels when the surrounding landscape was complex. Species richness and activity density of carabid beetles did not differ between organic and conventional fields, but increased with increasing landscape complexity. Species richness of spiders was also enhanced by landscape complexity, while organic farming supported high activity densities. Complex landscapes were related to high mortality of cereal aphids caused by parasitism, but also to higher aphid colonisation, counterbalancing possible biological control and leading to similar aphid densities across landscapes. Although aphids colonised organic fields in lower densities than conventional fields, aphid densities were similar at the time of wheat milk ripening. Parasitism did not differ between the farming systems. Further, analyses at multiple spatial scales revealed that aphids respond to landscape complexity at larger spatial scales than their parasitoids, reflecting limited dispersal ability of these higher trophic level organisms. With the help of a field experiment, we could show that Metopolophium dirhodum colonised weedless wheat plots in four times higher densities than plots containing arable weeds with $20 \%$ vegetation cover. Abundance of weeds, especially with $20 \%$ vegetation cover, enhanced aphid predators. Accordingly, densities of the released 
Sitobion avenae and also of naturally occurring aphids were lowest in this treatment (500\% lower than in the control), thereby falling below the threshold level of economic damage.

Results show that organic farming as well as complex landscapes may support species richness. However, organic farming unexpectedly did not influence parasitism of cereal aphids, whereas landscape complexity enhanced parasitoid, but also aphid populations. Abundance of arable weeds increased aphid predators and decreased aphid populations. Consequently, to conserve and support species richness and ecological functions in agricultural landscapes, we suggest to enhance the area of organically managed arable land, especially in structurally simple landscapes. Further, near-natural habitats such as grasslands, fallows and hedges should be maintained and renewed, respectively, because landscape complexity was shown to be of major importance for biodiversity and ecosystem functioning. 


\section{Zusammenfassung}

Durch die Intensivierung des Ackerbaus und die flächendeckende landwirtschaftliche Nutzung, die mit der Zerstörung perennierender, halbnatürlicher Habitate einherging, wurde die Landwirtschaft zu einem der Hauptverursacher des Artenrückgangs. Biodiversitätsverluste können auch zu einem Verlust wichtiger Ökosystemfunktionen wie z.B. der biologischen Schädlingskontrolle führen, was sich wiederum negativ auf die landwirtschaftliche Produktion auswirken kann. Einjährige Kulturen sind hauptsächlich Lebensraum für Organismen, die einen Teil ihres Lebenszyklus in anderen, perennierenden Habitaten verbringen. Annuelle Ackerwildpflanzenpopulationen überdauern zwar mit ihrer Samenbank, können aber auch von einem Sameneinflug aus der Landschaft profitieren. Daher scheint es nicht nur wichtig, die Lebensbedingungen der Organismen im Feld, z.B. durch extensive Anbaumethoden wie den ökologischen Landbau zu fördern, sondern auch die Struktur der umgebenden Landschaft zu berücksichtigen. In dieser Arbeit wurde untersucht, welche relative Bedeutung die Bewirtschaftungsweise (ökologisch vs. konventionell) und die Landschaftskomplexität für den Artenreichtum von Ackerwildpflanzen, den Artenreichtum und die Aktivitätsdichte von Laufkäfern und bodenlebenden Spinnen, sowie für die biologische Kontrolle von Getreideblattläusen durch Blattlausparasitoide in Winterweizenfeldern haben. Ferner wurde die Rolle der Ackerwildpflanzen für Interaktionen zwischen Getreideblattläusen und natürlichen Gegenspielern anhand eines Freilandexperimentes untersucht.

Ein Großteil der Untersuchungen fand in insgesamt 72 Winterweizenfeldern in der Umgebung von Göttingen statt (pro Jahr jeweils ein ökologisches und ein konventionelles Feld in 12 verschiedenen Landschaftsausschnitten). Nachdem bei der Untersuchung der Bewirtschaftungsintensität sehr heterogene Beziehungen zur Landschaftskomplexität entdeckt wurden, wurde bei der Flächenauswahl für die weiteren Untersuchungen darauf geachtet, Parameter wie Flächengröße sowie Pestizid- und Düngereinsatz möglichst konstant zu halten. Der regionale Artenreichtum von Ackerwildpflanzen wurde stark durch die Unterschiedlichkeit der Arten zwischen den Feldern geprägt. Auf Feldebene generierte der ökologische Landbau deutlich mehr Pflanzenarten, allerdings wurden in strukturreichen Landschaften in konventionellen Feldern ähnlich hohe Artenzahlen nachgewiesen. Artenreichtum und Aktivitätsdichten von Laufkäfern unterschieden sich nicht zwischen ökologischen und konventionellen Feldern, nahmen aber mit zunehmender Landschaftskomplexität zu. Der Artenreichtum bodenlebender Spinnen stieg ebenfalls mit zunehmender Landschaftskomplexität, während hohe Aktivitätsdichten durch ökologische Bewirtschaftung gefördert wurden. Die Mortalität von Getreideblattläusen aufgrund von Parasitierung war in komplexen Landschaften erhöht, allerdings fand dort auch eine verstärkte Besiedlung der Felder durch die Läuse statt, was eine mögliche biologische Kontrolle hintertrieb und letztendlich $\mathrm{zu}$ gleichen Blattlausdichten in allen Landschaften führte. 
Ökologische Felder zeigten zwar eine geringere Blattlausbesiedlung, zur Zeit der Milchreife des Weizens jedoch gleiche Blattlausdichten wie konventionelle Felder. Auf die Parasitierungsraten hatte die Bewirtschaftungsweise keinen Einfluss. Analysen auf multiplen räumlichen Skalen zeigten, dass Blattläuse noch auf deutlich größeren Skalen auf die Landschaft reagieren als ihre Parasitoide, was auf eine Ausbreitungslimitierung der höheren trophischen Ebene schließen lässt. In einem Freilandexperiment konnte gezeigt werden, dass unkrautfreie Weizenparzellen in vierfach höheren Dichten von den natürlicherweise vorkommenden Metopolophium dirhodum besiedelt wurden als Parzellen mit 20\% Wildpflanzendeckung. Die Abundanz von Wildpflanzen erhöhte auch die Prädatorendichten, besonders in Parzellen mit 20\% Wildpflanzendeckung. Folglich waren Dichten der experimentell zugesetzten Sitobion avenae, aber auch der anderen Blattläuse, in diesen Parzellen am geringsten (500\% niedriger als in der unkrautlosen Kontrolle) und unterhalb der wirtschaftlichen Schadschwelle.

Die Ergebnisse zeigen, dass sowohl ökologischer Landbau als auch komplex strukturierte Landschaften Artenreichtum fördern können. Ökologischer Landbau hatte jedoch keinen Einfluss auf die Parasitierung von Blattläusen, während Landschaftskomplexität zwar Parasitoide förderte, aber auch die Blattläuse selbst. Verunkrautung förderte nachweislich räuberische Blattlausgegenspieler und hemmte die Blattlauspopulationen. Um Artenreichtum und Ökosystemfunktionen in der Agrarlandschaft optimal zu schützen und zu fördern, scheint es sinnvoll, ökologischen Landbau flächenmäßig weiter auszudehnen, und hierbei vor allem ausgeräumte Landschaften mit geringer Landschaftskomplexität $\mathrm{zu}$ berücksichtigen. Weiterhin sollten naturnahe Lebensräume wie Grünländer, Brachen und Hecken erhalten, bzw. deren Neuanlegung gefördert werden, da die Landschaftskomplexität von großer Bedeutung für Biodiversität und Ökosystemfunktionen sein kann. 


\section{Acknowledgements}

Herzlich bedanken möchte ich mich bei Herrn Prof. Dr. Teja Tscharntke für die Bereitstellung des interessanten Themas sowie die gute Betreuung in meiner gesamten Promotionszeit.

Herrn Prof. Dr. Stefan Vidal danke ich für die freundliche Übernahme des Korreferats.

Mein besonderer Dank gilt Dr. Carsten Thies für die gute Zusammenarbeit und die Hilfestellung bei kleineren und größeren Problemen bei der Planung und Durchführung meines Forschungsprojektes, und bei der Veröffentlichung der Ergebnisse. Danke auch für unseren gemeinsamen Proceedings-Artikel!

Der Deutschen Forschungsgemeinschaft danke ich für die finanzielle Unterstützung des Projektes TS 45/18-1,2. In der Zeit davor erhielt ich für einige Monate ein Promotionsstipendium nach dem Nieders. Graduiertenförderungsgesetz vom 17.11.1984 Nds. GVB1. S. 257-.

Dr. Martin Schmidt und Dr. Tobias Purtauf danke ich für die Auswertung meiner Barberfallenfänge, die mit zwei schönen Veröffentlichungen endete.

Melanie Hücker war mir im Rahmen ihrer Diplomarbeit und anschließend als wissenschaftliche Hilfskraft eine sehr große Hilfe. Viele HiWis sowie Mechthild Rittmeier haben Arbeiten für mich erledigt, die ich zeitlich nicht hätte bewältigen können.

Bei allen MitarbeiterInnen des Fachgebiets Agrarökologie bedanke ich mich für die schöne Arbeitsatmosphäre. Ohne Doreen Gabriel und Christof Bürger hätte meine Landschaftsauswertung nicht stattfinden können, und Doreen und ich haben uns in Sachen Unkräutern gegenseitig unterstützt, was zu gemeinsamen Publikationen führte. Katja Poveda half vor allem bei statistischen Problemen und durch ihre Anwesenheit, die ein tolles Arbeitsklima in Zimmer 415 schaffte. Catrin Westphal, Jochen Krauss, Sabine Eber und Barbara Scheid waren fachlichen (und privaten) Diskussionen gegenüber immer aufgeschlossen, und Barbara gab GIS-Hilfestellungen. Hella Grabe und Susanne Schiele waren in Organisationsfragen und bei technischen Problemen immer hilfsbereit.

Vielen Dank an über 50 Landwirte! Sie gaben bereitwillig Auskunft über Betriebs- und Bewirtschaftungskennzahlen und/oder ließen mich auf ihren Weizenäckern arbeiten.

Schließlich möchte ich mich ganz besonders bei meiner Familie, vor allem bei meinen Eltern, und bei Klaus Krüger sowie allen meinen Freunden bedanken, die für Ablenkung und Ausgleich sorgten und mich unterstützten, wo immer sie konnten.

Euch allen ganz herzlichen Dank!!! 


\section{Publications}

Roschewitz, I., Tscharntke, T., Thies, C. (submitted) The role of arable weeds in cereal aphid-natural enemy interactions.

Roschewitz, I., Gabriel, D., Tscharntke, T., Thies, C. (submitted) The effects of landscape complexity on arable weed species diversity in organic and conventional farming.

Gabriel, D., Roschewitz, I., Thies, C., Tscharntke, T. (submitted) Relative importance of beta diversity at different spatial scales - plant communities in organic and conventional agriculture.

Roschewitz, I., Hücker, M., Tscharntke, T., Thies, C. (2005) The influence of landscape context and farming practices on parasitism of cereal aphids. Agriculture, Ecosystems and Environment, in press.

Purtauf, T., Roschewitz, I., Dauber, J., Thies, C., Tscharntke, T., Wolters, V. (2005) Landscape context of organic and conventional farms: influences on carabid beetle diversity. Agriculture, Ecosystems and Environment, in press.

Schmidt, M.H., Roschewitz, I., Thies, C., Tscharntke T. (2005) The differential effects of landscape and management on diversity and density of ground-dwelling farmland spiders. Journal of Applied Ecology, in press.

Thies, C., Roschewitz, I., Tscharntke, T. (2005) The landscape context of cereal aphidparasitoid interactions. Proceedings of the Royal Society of London, Series B: Biological Sciences, 272, 203-210.

Roschewitz, I., Thies, C., Tscharntke, T., (2005) Are landscape complexity and farm specialisation related to land-use intensity of annual crop fields? Agriculture, Ecosystems and Environment 105, 89-99.

Roschewitz, I., Tscharntke, T., Thies, C. (2004) Effects of farming system and landscape heterogeneity on the diversity of weeds and their seedbank in winter wheat fields. Verhandlungen der Gesellschaft für Ökologie, Band 34, p 207.

Roschewitz, I., Hücker, M., Thies, C., Tscharntke, T. (2003) Farming system and landscape context influence biocontrol of cereal aphids. Verhandlungen der Gesellschaft für Ökologie, Band 33, p 59.

Roschewitz, I., Thies, C., Tscharntke, T. (2002) Land-use intensity of annual crop fields and landscape complexity. Verhandlungen der Gesellschaft für Ökologie, Band 32, p 358. 
Roschewitz, I. (2002) Der Einfluss der Landschaftsstruktur auf Artenvielfalt und ökologische Interaktionen in der ökologischen und konventionellen Landwirtschaft. In: Wiersbinski, N. (ed.): Naturschutz und ökologischer Landbau - Forschungsbedarf und Fördermöglichkeiten. BfN-Skripten 72, pp. 81-84.

Fuhge, D., Gernhardt, J., Roschewitz, I., Xiromeriti, K. (1999) Regionalvermarktung von ökologisch erzeugten Produkten am Beispiel des nexus-Projektes. Landwirtschaft und Umwelt 8, pp. 25-35. 


\section{Curriculum Vitae}

Indra Roschewitz

born 16.06.1976 in Stadtoldendorf

2001-2005 Ph-D Studies at the Agroecology Department of the Georg-AugustUniversity in Göttingen under the supervision of Prof. Dr. Teja Tscharntke Financially supported by a "Promotionsstipendium nach dem Niedersächsischen Graduiertenförderungsgesetz vom 17.11.1984 - Nds. GVB1. S. 257-“, and by the German Science Foundation: Deutsche Forschungsgemeinschaft (DFG)

2001 Completion of the Agricultural Sciences studies, graded with ,sehr gut“

2000-2001 Diploma thesis on „Die Landbewirtschaftung in unterschiedlich strukturierten Landschaften Südniedersachsens" at the Agroecology Department of the Georg-August-University in Göttingen

Supervisor: Prof. Dr. T. Tscharntke

1995-2001 Agricultural Sciences studies at the Georg-August-University in Göttingen Main focus: Agriculture and environment

Completion of the school at the Campe-Gymnasium Holzminden with the Abitur 